CROSS-ROADS. POLISH STUDIES IN CULTURE, LITERARY THEORY, AND HISTORY 12

Adam Dziadek

\title{
Somatic Criticism Project
}

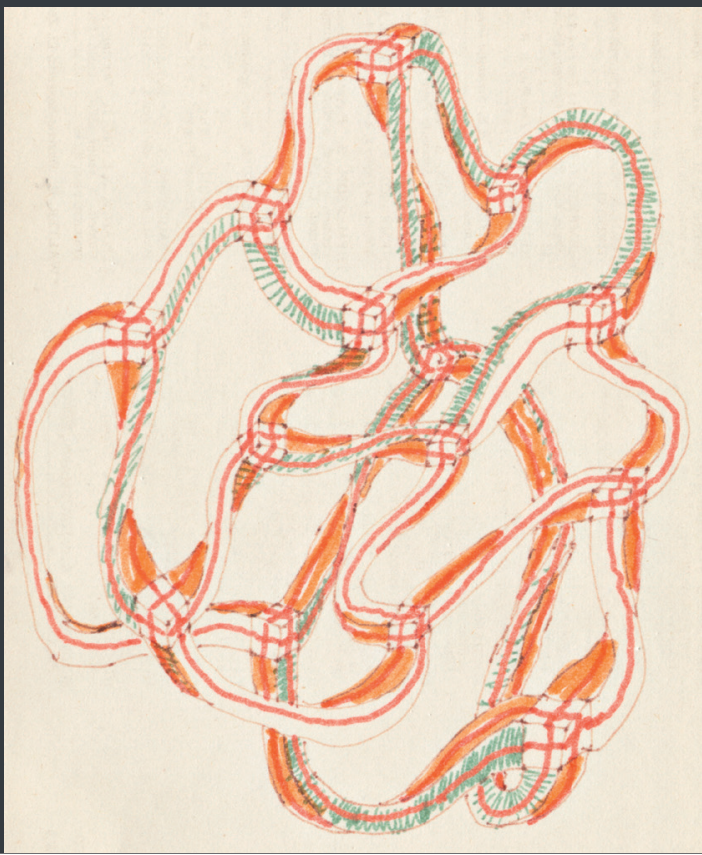




\section{CROSS-ROADS. POLISH STUDIES IN CULTURE, LITERARY THEORY, AND HISTORY 12}

\section{Adam Dziadek}

\section{Somatic Criticism Project}

This book illustrates the problems connected with the body and the sign: the real body and the body of the text, somaticism and semiology (both as a general sign theory and in the medical sense as "symptomatology"). The author seeks to derive a more general principle from these two words, referring to the representation of experience in different literary texts. If we are talking about the representation of experience, we cannot, by any means, ignore the body that becomes the essential point of reference for human experience. This general principle aims at creating a matter of concept, a somatic criticism project, which is closely related to the issue of rhythm in literary texts - a rhythm understood as an intermediary between the body and the sense of the text.

\section{The Author}

Adam Dziadek is Professor of Literature at the University of Silesia in Katowice. His main research areas are the theory of literature, the history of literature and comparative literature, as well as the translation of scientific texts. He also deals with problems of editing and genetic criticism. He translated, among others, Roland Barthes, Jacques Derrida and Jean-Luc Nancy into Polish. 
Somatic Criticism Project 


\section{Cross-Roads. \\ Polish Studies in Culture, Literary Theory, and History}

Edited by Ryszard Nycz

Volume 12

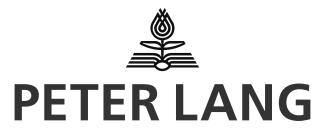




\title{
Adam Dziadek
}

\section{Somatic Criticism Project}

\author{
Translated by Lindsay Davidson
}




\title{
Bibliographic Information published by the Deutsche Nationalbibliothek
}

The Deutsche Nationalbibliothek lists this publication in the Deutsche Nationalbibliografie; detailed bibliographic data is available in the internet at http://dnb.d-nb.de.

\section{Library of Congress Cataloging-in-Publication Data \\ A CIP catalog record for this book has been applied for at the Library of Congress.}

This publication is funded by Ministry of Science and Higher Education of the Republic of Poland as a part of the National Program for the Development of the Humanities in the years 2016-2019 (project number: 3aH 15016583 ).

The publication reflects the views only of the author, and the Ministry cannot be held responsible for any use which may be made of the information contained therein.

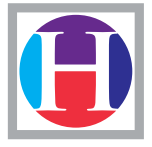

\section{NARODOWY PROGRAM ROZWOJU HUMANISTYKI}

The research grant was carried out at the University of Silesia in Katowice.

Cover image: Stefan Themerson, «Drawing (untitled)», from the collection of Adam Dziadek

Cover Design: @ Olaf Gloeckler, Atelier Platen, Friedberg

\author{
ISSN 2191-6179 \\ ISBN 978-3-631-67428-4 (Print) E-ISBN 978-3-653-06836-8 (E-PDF) \\ E-ISBN 978-3-653-70881-1 (E-Pub) E-ISBN 978-3-653-70882-8 (mobi)
}

DOI 10.3726/b14659

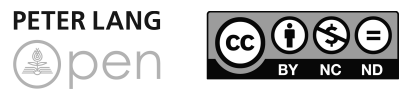

Open Access: This work is licensed under a Creative Commons Attribution Non Commercial No Derivatives 4.0 unported license. To view a copy of this license, visit https://creativecommons.org/licenses/by-nc-nd/4.0/

(c) Adam Dziadek, 2018

Peter Lang - Berlin · Bern · Bruxelles - New York ·

Oxford $\cdot$ Warszawa $\cdot$ Wien

This publication has been peer reviewed.

www.peterlang.com 
For Ania, Ola and Olek 



\section{Table of Contents}

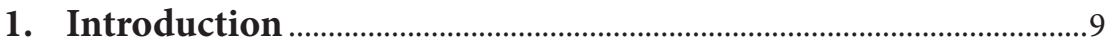

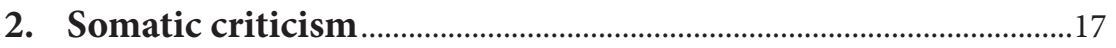

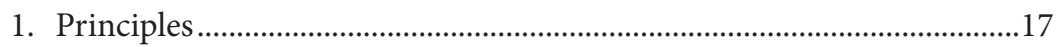

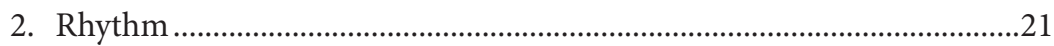

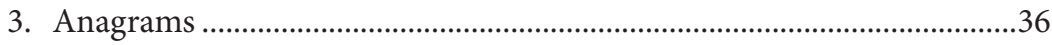

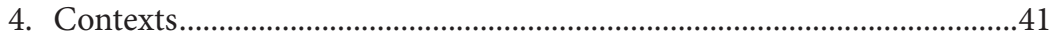

3. Somatic writing, touching sense - Aleksander Wat ...................47

4. Somatic style - Eugeniusz Tkaczyszyn-Dycki...............................73

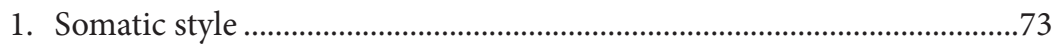

2. Body and entity.......................................................................................

3. Body and word..........................................................................................

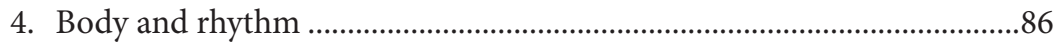

5. Sound effects - about Joanna Pollakówna's poems.......................89

6. Listening as a somatic experience - about

Edward Pasewicz's verses ..................................................................... 109

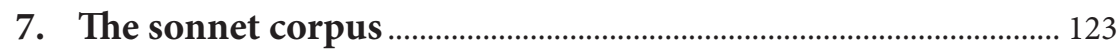

1. Supplement............................................................................................... 149

8. Somatext: word, picture and rhythm ………………………......... 157

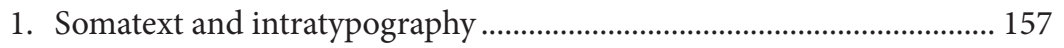

2. Intratypography and poetic texts ........................................................... 159 
3. Words in pictures, pictures in words

4. Polymorphic text - about the typographic work of the Themersons.

Bibliography 201

Index of names 


\section{Introduction}

The body in the culture and humanities of the twentieth and twenty-first centuries occupies a position which is exceptionally privileged, if not quite simply central. It is even said that it is a theoretical invention of the twentieth century, an idea underlined by sociological-historical research of this phenomenon ${ }^{1}$. If we take a closer look at the history of the body in the past century, we can clearly see the revolutionary changes it has undergone as a biological being and also as a socio-philosophical construct. Revolutions in the sphere of sexuality, which in gradual transformation, have released it from boundaries, rules and religious and ethical norms, and people finally recognise the right to enjoyment, which is today almost universally recognised and accepted. They also concern medicine, which during its development has learned not only to improve the healing process, to prolong human life, but also to transform the body, to shape and to improve it. The twentieth-century body also has other experiences in its memory that have never taken place in history before, such as the bodies massacred during two world wars, the bodies reified and exterminated in concentration camps, and the bodies deprived of identity and instrumentalised in totalitarian systems.

The body associated with the concept of the subject has become the central issue of philosophical and anthropological research. The work of Gilles Deleuze and Félix Guattari (starting with L'Anti-Oedipe) and Michel Foucault (Discipline and Punish, The History of Sexuality), referring directly to politics and power, revealing the mechanisms of their functioning, will also constitute the basic point of reference in the reflection about the body and will determine the main directions of thinking about this phenomenon in anthropology, philosophy, sociology, gender studies, feminist literary criticism and queer theory.

Many of these directions in humanities studies were developing in the second half of the twentieth century. For example, the sociology of the body began to form in the early 1980s within British sociology ${ }^{2}$ and centred on social activities, social exchange, cultural representations of the human body, social nature of the spectacle and reproduction of the body and population in the social structure. The body is also understood here as a cultural representation of social

1 J.-J. Courtine, Introduction, [in:] idem, Histoire du corps. Les mutations du regard. Le $X X^{e}$ siècle, ed. J.-J. Courtine, vol. 3, Paris 2006, p. 7.

2 B.S. Turner, The Sociology of the Body, [in:] idem, The New Blackwell Companion to Social Theory, Oxford 2009, p. 515. 
organisation and power relations. In the postmodern era, the sociology of the body as well as many other disciplines (including literary criticism) were and are still being fuelled by other modes of humanistic thought - queer, lesbian studies, gay studies, dance studies and feminist literary criticism that created a completely new type of sensitivity (gender sensitivity) and made it possible to uncover such areas of knowledge that were previously completely ignored. They not only radically changed the way of reading cultural texts but, above all, they revolutionised the way we think about man and society.

At the end of the twentieth century and at the beginning of the twentyfirst century, we increasingly speak of the postmodern body, the perfect body, organised better than nature. This body is nourished, put through diets, exercised, built (body-building), regulated (regulating bodies as in Bryan S. Turner, who carefully analyses the body in the context of the latest developments and changes taking place in medicine), rebuilt (remaking the body - as in Wendy Seymour) or modified (body modification - as in Victoria Pitts) ${ }^{3}$. The body has also become plastic because it can be sculpted, tattooed (body as canvas, image and text), shaped, stylised; it can be modified in hundreds of ways ${ }^{4}$ and its natural form can be changed, endlessly improved. In visual arts, it is constantly subject to aestheticisation, but is also subject to defiguration or is mechanised (cyborgs, mutants). The human body went through a transformation into the posthuman body ${ }^{5}$, described in academic treatises or - exceptionally accurately - in poetic

3 B.S. Turner, Regulating Bodies. Essays in Medical Sociology, London 1992; W. Seymour, Remaking the Body: Rehabilitation and Change, London 1998; V. Pitts, In the Flesh: The Cultural Politics of Body Modification, New York 2003.

4 In this matter it is enough to reach for N. Allison's book The Illustrated Encyclopedia of Body-Mind Disciplines (New York 1999), in order to see how many modern methods of improving and correcting the human body are known to people today. Their alphabetic listing and encyclopedic description are nearly 450 pages long.

5 See for example B. Bodzioch-Bryła, Ku ciału postludzkiemu... Poezja polska po 1989 roku. Wobec nowych mediów i nowej rzeczywistości, Cracow 2006; J. Protevi, Political Affect. Connecting the Social and the Somatic, Minneapolis 2009. Protevi's book appeared in the series "Posthumanities", which currently covers more than 30 publications devoted to posthumanism and the various conditions to which the posthuman body is subjected (technology, biopolitics, ecology, etc.). See also N.K. Hayles, How We Became Posthuman. Virtual Bodies in Cybernetics, Literature and Informatics, Chicago 1999; C. Waldby, The Visible Human Project. Informatic Bodies and Posthuman Medicine, London 2000; A. Weinstone, Avatar Bodies. A Tantra for Posthumanism, Minneapolis 2004; A. Lemma, Under the Skin. Psychoanalytic Study of Body Modification, New York 2010; M. Bakke, Bio-transfiguracje. Sztuka i estetyka posthumanizmu, Poznań 2010. 
texts, as in Maria Peszek (from the CD Maria Awaria from 2008 - I consider this text as poetic, and not just lyrics, the verbal element of the musical text):

Kobiety pistolety

Są kobiety pistolety

i kobiety jak rakiety

chude, długie i wysokie

$\mathrm{z}$ wydepilowanym krokiem

Są kobiety bezzmarszczkowe

fit kobiety luksusowe

pielęgnacji wciąż oddane

$\mathrm{z}$ samych siebie odessane

Są kobiety pistolety

pielęgnacji wciąż oddane

$\mathrm{z}$ samych siebie odessane

A ja dla własnej wygody zapuszczam swe ogrody

i kolekcjonuje wzwody

ja, metr pięćdziesiąt dwa

Są kobiety pistolety

i kobiety jak rakiety chude, długie, opalone

$\mathrm{z}$ wydepilowanym tonem

Są kobiety doskonałe

z wyrzeźbionym gładkim ciałem

odmłodzone, odbarwione

całkiem z wieku odsączone

A ja dla własnej wygody zapuszczam swe ogrody

i kolekcjonuję wzwody

ja, metr pięćdziesiąt dwa

dziko rosnącego nieba

Lubię skóry mojej smak

i fakt, że zawsze jestem na tak

i lubię też, w moich ustach słowo „fuck”

I lubię ten smak, gdy w ustach mam

słowo „fuck” 
["Women Pistols // There are women pistols / and women like rockets / thin, long and tall / with a depilated walk // There are wrinkleless women / fit women luxury / care still devoted / sucked up with themselves // There are women pistols / taken still to care / sucked up with themselves // And I for my own convenience / neglect my own gardens / and collect erections / me, one meter fifty two // There are women pistols / and women like rockets / thin, long, tanned / with depilated womb // There are perfect women / with their body sculpted smooth / rejuvenated, discoloured / quite from age drained off // And I for my own convenience / neglect my own gardens / and collect erections / me, one meter fifty two / of wildly growing heaven // I like the skin of my taste / And the fact, that I always am for yes / and I also like, the word "fuck" in my mouth // And I like this taste, when I have the word / "fuck" in my mouth"]

The ubiquity of the body in culture, the variety of forms of its presence, allows Bryan S. Turner to draw attention to the fact that we live in a "somatic society", in which all political, moral and personal issues are problematised in the body and expressed through the body. Turner also stresses that in the postmodern era, the body became the basic theme of civilisation under the somatic regime. Another sociologist, dealing with consumer culture, makes a significant travesty of Descartes' words, and with a shade of irony states: "I embody therefore I am" .

Within the humanities for many years now we have been dealing with the "somatic turn" (the term corporeal turn ${ }^{8}$ is also in use). In the work from the field of sociology of the body The Body, Culture and Society", the authors recognise the designation as equivalent in the social sciences discourse and put it next to the "linguistic turn" and the "cultural turn" (it would be necessary here to add many others that went alongside those: the aesthetic turn, iconic turn, geographic or spatial turn, biological turn):

To engage with the somatic turn this book focuses on a series of 'typical' bodies that correspond to those substantive subject areas in which the meaning of the contemporary body (arguably) is most vigorously contested. ${ }^{10}$

In the context of somaesthetics, the body also appears in Richard Shusterman's work The Somatic Turn: Care of the Body in Contemporary Culture (the somatic turn as an expression of the need to find a stable point of reference in a rapidly

6 B.S. Turner, The Body and Society. Explorations in Social Theory, London 1996, p. 6.

7 P. Corrigan, The Sociology of Consumption. An Introduction, London 1997, p. 160.

8 See for example B. Farnell, Dynamic Embodiment for Social Theory: "I Move Therefore I Am", London 2012.

9 The Body, Culture and Society. An Introduction, ed. P. Hancock et al., Philadelphia 2000, p. 10.

10 Ibidem, p. 11. 
changing world; as a defensive reaction against uniformity, the body is treated with religious reverence but far from religion itself; the somatic turn as part of the aesthetic turn in contemporary culture; evolutionary crisis - the necessity of rethinking our relationship with ourselves and the world around us, the concern for the body $)^{11}$. Brenda Farnell speaks of two somatic turns. The first somatic turn took place at the end of the twentieth century, inspired by the thinking of Foucault and focused on the body as a social object, and also on the experience of the lived body (here the inspiration was Maurice Merleau-Ponty). The second is Farnell's proposal, which places emphasis on bodily movement, on people in motion and meaning; the first grows directly from phenomenology, the other is connected with semasiology (the human being as maker of meaning - the basic idea systematically developed in the work of Drid Williams in the field of visual anthropology and dance studies, exploring forms of meaning in motion $)^{12}$.

It is significant that none of the disciplines develops the problem of the body or of corporeality based on the tools developed within itself alone - the sociological or literary criticism discourse moves towards psychoanalysis, philosophy or anthropology and vice versa. Such a problem cannot be explored on the basis of the homogeneous discourse of a particular discipline. I am not referring to the barren, obscure, overused and in recent times overly proliferous definition "interdisciplinarity". To deal with the problem of corporeality in literature at present implies the necessity of referring to other areas of humanistic science - I underline the word "necessity" on account of the thematic ubiquity of the body in literature and contemporary culture, in works of criticism and in scientific papers from various fields of the humanities.

The same problem also applies to the area of knowledge of literature - and here also we have been dealing with just such a "somatic turn" for many years, as witnessed by the 1990s as well as recent years, which have also brought extraordinary interest in Polish literary criticism in the body and in corporeality ${ }^{13}$.

There have been many works rooted in various philosophical and methodological options. Amongst the most interesting are those that refer to methodologies

11 See R. Shusterman, Performing Live, Ithaca 2000, pp. 162-166.

12 B. Farnell, Dynamic Embodiment for Social Theory..., p. 10.

13 I confine myself to the most important works devoted to the issues of the body and corporeality that appeared in Poland at the end of the twentieth century and in the twenty-first century. It must be noted, however, that works concerned with these issues appeared earlier, to mention here at least: J. Łukasiewicz, Laur i ciało, Warsaw 1971; P. Dybel, Ziemscy, słowni i cieleśni. Eseje i szkice, Warsaw 1988; T. Drewnowski, Walka o oddech. O pisarstwie Tadeusza Różewicza, Warsaw 1990. 
completely new to Poland (feminist literary criticism, gender studies), which address the problematics of the body: Grażyna Borkowska's Cudzoziemki. Studia o polskiej prozie kobiecej; Krystyna Kłosińska’s Ciało, pożądanie, ubranie. O wczesnych powieściach Gabrieli Zapolskiej; Ewa Kraskowska’s Piórem niewieścim. Z problemów prozy kobiecej dwudziestolecia międzywojennego, two volumes of collective works Ciało i tekst. Feminizm w literaturoznawstwie and German Ritz’s Nić w labiryncie pożadania. Gender i pleć w literaturze polskiej od romantyzmu do postmodernizmu ${ }^{14}$.

The following years also bring many thematic approaches, whose methodological foundations are heterogeneous (and of course they do not have to be like this), as they stem from different sources and methodological inspirations (many of these are collective works): Między słowem a ciałem, Ciało granice kanon, Codzienne, przedmiotowe, cielesne or also Cielesność w polskiej poezji najnowszej ${ }^{15}$. Two monographs deserve particular attention: Beata Przymuszała's Szukanie dotyku and Anna Filipowicz's Sztuka mięsa [this title is a play on words and can mean both Piece of meat and The art of meat] - both dedicated to poetry. The first of these constitutes a comprehensive discussion of the problems of the body and corporeality in Polish contemporary poetry in an interdisciplinary perspective (cultural criticism, philosophical, theological and literary criticism perspectives), the second - with the significant subtitle Somatyczne oblicza poezji

14 G. Borkowska, Cudzoziemki. Studia o polskiej prozie kobiecej, Warsaw 1996; K. Kłosińska, Ciało, pożądanie, ubranie. O wczesnych powieściach Gabrieli Zapolskiej, Cracow 1999; E. Kraskowska, Piórem niewieścim. Z problemów prozy kobiecej dwudziestolecia międzywojennego, Poznań 1999; Ciało, płeć, literatura, ed. M. Hornung, M. Jędrzejczak, T. Korsak, Warsaw 2001; Ciało i tekst. Feminizm w literaturoznawstwie. Antologia szkiców, ed. A. Nasiłowska, vol. 1, Warsaw 2001; Ciało i tekst. Feminizm w literaturoznawstwie. Antologia szkiców, ed. A. Nasiłowska, vol. 2, Warsaw 2009; G. Ritz, Nić w labiryncie pożądania. Gender i płeć w literaturze polskiej od romantyzmu do postmodernizmu, Warsaw 2002.

15 Między słowem a ciałem, ed. L. Wiśniewska, Bydgoszcz 2001; Codzienne, przedmiotowe, cielesne. Języki nowej wrażliwości w literaturze polskiej XX wieku, ed. H. Gosk, Warsaw 2002; B. Przymuszała, Szukanie dotyku. Problematyka ciała w polskiej poezji współczesnej, Cracow 2006; Ciało, granice, kanon, ed. J. Olejniczak, Katowice 2008; Cielesność w polskiej poezji najnowszej, ed. T. Cieślak, K. Pietrych, Łódź 2010; A. Filipowicz, Sztuka mięsa. Somatyczne oblicza poezji, Gdańsk 2013. See also: Doświadczane, opisywane, symboliczne. Ciało w dyskursach kulturowych, ed. K. Łeńska-Bąk, M. Sztandara, Opole 2008; A. Łebkowska, Jak ucieleśnić ciało?, „Teksty Drugie” 2011, No. 4, pp. 11-27, and also Texts and the Body - a thematic issue of „Teksty Drugie” from 2013. 
[The somatic face of poetry] - in a very interesting manner tackles the question of "meatiness" in contemporary Polish poetry ${ }^{16}$.

The project of somatic criticism proposed by me is against the background of all corporeal turns of an atypical phenomena. This is not a work about the presence of the body in literature in a thematic, cultural or gender context. This is not the poetics of the body proposed by Catherine Cucinella, writing about textual and bodily convergence, poetic bodies or writing a corporeal palimpsest, nor is it a situation in which the word is made from the body (flesh made word), as it functions in the work of Judith Roof, who analyses DNA (including textual metaphors in the description of DNA aided by formulae of the type "book of life", "code", "alphabet", "blueprint" assuring man of the existence of control over genetic processes) ${ }^{17}$.

In terms of methodology, the project enters into a relationship with a number of other fields and it is possible to expand into many others; however, at this stage particular emphasis is placed first and foremost on the philosophical-linguistic theory of rhythm (Émile Benveniste, particularly Henri Meschonnic) and semiotics (Julia Kristeva) - more about this later in this discussion. These are issues I have previously addressed in my research, and it is worth thinking about, I think, to verify, by referring to other works that have recently appeared, and to develop today a project of reading various literary texts of the twentieth and twenty-first centuries. Using the word "criticism" in the title, I am not thinking of any kind of literary criticism activity, which involves tracking, discussing, judging or evaluating current literary publications, but I understand this term as it is understood in French or English or American literary criticism (for example New Criticism, Reader-Response Criticism, Archetypal Criticism, critique thématique), and so as a kind of research activity.

The fundamental matter is the trace of the body in text. Their identification due to rhythm, which is the most important sign of carnality in the text, testifies to the uniqueness of each text and becomes the signature of the speaking subject. This is also about the reception of the text, in which the body and the various senses involved in the reading process are mediated (hearing - poetic sensitivity to sound and listening to texts, the sound systems contained in them; sight - the layout of the text on the page, the associated image, their mutual dependencies that shape the rhythm of the text in yet another way). Finally, this is about the

16 B. Przymuszała, Szukanie dotyku...; A. Filipowicz, Sztuka mięsa....

17 C. Cucinella, Poetics of the Body. Edna St. Vincent Millay, Elizabeth Bishop, Marilyn Chin, Marilyn Hacker, New York 2010; J. Roof, The Poetics of DNA, Minneapolis 2007. 
sensual layer of literary text, the materiality and the corporeality of the poetic word which is lined with amongst other things the articulation kinaesthesia. The subject of the analyses is usually single texts - the fundamental principle is the singularity of the creative act and the act of reading, the identification and analysis of the factors that decide on this singularity are essential. 


\section{Somatic criticism}

\section{Principles}

What should somatic criticism be? The name itself does not appear at all in the literary criticism discourse. Only similar forms exist. It is true that Terry Eagleton used the name somatic criticism in Figures of Dissent to define a broad field of research in the area of cultural studies ${ }^{18}$, but he used it with an ironic meaning, claiming that more bodies will soon be found in contemporary research than on the fields of Waterloo, and books from the field of soft porn will soon be difficult to distinguish on the bookshelves from works in the field of literary theory. A similar name is "critical somatics", which was used by Nicole Anderson ${ }^{19}$ in her work - the intention of the author of a programme of activities for students was to be a new discipline serving thematisation of the culturally and socially productive body. This is about teaching bodily behaviour in the social and cultural space, which is inspired by the thoughts of Marcel Mauss (Les techniques $d u$ corps) and also very broadly by the work of Richard Shusterman dedicated to somaesthetics. Such a perspective, despite the closeness in name, has nothing to do with the project of somatic criticism. In turn, the term "somatics of literature" appears in Douglas Robinson's book Estrangement and the Somatics of Literature $^{20}$, referring to somatic theory and dedicated to the work of Leo Tolstoy, Viktor Shklovsky and Bertolt Brecht. The concept itself is related to Tolstoy and his theory of contamination by literature (literature infects the reader with the author's emotions, which later direct the reader's good or bad behaviour), and in this book constitutes the basis for a "somatic theory of literature"21.

To clarify the basic assumptions of the somatic criticism project, I refer to two Greek words sôma and sema - their juxtaposition looks like a play on words, but

18 T. Eagleton, Figures of Dissent: Critical Essays on Fish, Spivak, Žižek, and Others, London 2003, p. 131.

19 N. Anderson, Critical Somatics: Theory and Method, Marylhurst University, Portland 2010.

20 D. Robinson, Estrangement and the Somatics of Literature. Tolstoy - Shklovsky - Brecht, Baltimore 2008.

21 Ibidem, p. X. Robinson is also the author of other works, in which the "somatic" idea plays an important role: Displacement and the Somatics of Postcolonial Culture, Columbus 2013. Somaticism is understood here as a cultural construct of reality and identity based on a regulated cycle of critical affect. 
upon closer examination, they cease to be an accidental display of words that differ only in one vowel. This juxtaposition shows the physical equivalence between the body and the sign ${ }^{22}$. These words also evoke a whole sequence of associations: the body and the sign, real body and body of text, somaticism and semiology (as the general theory of signs and in the medical sense as "symptomatology", and so the medical field concerned with the manifestations of illness), which makes it possible to link the criticism project with clinical practice ${ }^{23}$.

I would like to draw out a more general rule from these two words, referring to representation of somatic experience mainly in poetic texts, although the whole project could be extended to prose works. If we are talking about the representation of experience, it is impossible to bypass the body, which becomes the essential point of reference for human experience. This general principle tends to the direction, to name the problem factually, of a somatic criticism project.

What would be the scope of this project? What literary texts could be included in this project? It is obvious that there are no literary texts in which the body would be absent. However, this is a very general, even banal and insufficient statement which therefore demands unambiguous development.

The project could include, in the first instance, texts in which the body is thematised (named explicitly or through means of metonyms), and thus either is the subject of description or its subject becomes various types of bodily experiences (erotica, pain and suffering, sensory perception of reality, etc.). From one side it is about perception, from the other about the manner of representing bodily experiences in literary texts. Furthermore, it is also about somatic imagination images, pictures of the body, as well as the whole rich metaphorical sphere that influences the formation of these images. First and foremost, the important thing is the manner in which we find traces of the presence of the body in a variety of texts.

It is obvious that the source of perception is found in the body. Having a body signifies not only the possibility of seeing and perceiving, but also that of being

22 See H. Meschonnic, La Rime et la vie, Lagrasse 1989, p. 209.

23 My proposal for a project of somatic criticism differs significantly from the ideas contained in the book by G. Deleuze, Critique et clinique, Paris 1993. This project is also different from the somaesthetics of Richard Shusterman (R. Shusterman, $O$ sztuce i życiu. Od poetyki hip-hopu do filozofii somatycznej, transl. W. Małecki, academic collaboration A. Chmielewski, Wrocław 2007; R. Shusterman, Świadomość ciała. Dociekania z zakresu somaoestetyki, transl. W. Małecki, S. Stankiewicz, scientific ed. K. Wilkoszewska, Cracow 2010), although in Chapter IV I take his term "somatic style" and use it in a modified sense. 
seen and perceived. In other words, the body is an integral part of the world in the sense that it is part of the same organism. It is exactly through the world that makes possible something that can be defined as "going beyond oneself", going out $^{24}$. It is just through the commonality of all people that we have the opportunity to discover the Other, who, like us ourselves, is the "owner" of a body. This is a kind of spreading, branching out into the world. It is an "I" that allows both seeing and being seen.

The proposed project also has an aim that the selected texts have a highly visible metatextual layer (metaliterary reflection, autothematism, analysis of the act of writing, reflection on the possibilities and limits of linguistic representation, in short - strongly accentuated consciousness of the creative act, the act of writing). I note, however, that all autothematic views and metaliterary author statements can be the definitive point of reference for critical expression. They are also subject to analysis and interpretation, they are helpful but not binding in the final statement about any given text.

In the field of textual analysis in the presented project, one of the most important points of reference could be the words of Henri Meschonnic, who in his Critique du rythme offered an important thesis, posing that the "the body may only be rhythm in speech"25. In agreement with the assumptions of my project, the theories of rhythm of Henri Meschonnic and Julia Kristeva constitute the essential point of reference for the whole argument. For somatic criticism rhythm is one of the most important elements and the basis of microanalysis. However, it is necessary to understand the way it is understood ${ }^{26}$. And so, in agreement with Meschonnic's suggestions, it is seen like a set, through which language and nonlanguage signifiants produce a specific semantics, different from the lexical sense (signifiance - which becomes a secondary, supplementary value of speech ${ }^{27}$ ). These

24 Compare M. Frank, L’ultime raison du sujet, Arles 1988.

25 H. Meschonnic, Critique du rythme. Anthropologie historique du langage, Lagrasse 1982, p. 663.

26 I refer here to the definition of rhythm proposed by H. Meschonnic (ibidem, pp. 216-217) - see footnote 35. I discussed Meschonnic's theory of rhythm earlier in: A. Dziadek, Rytm i podmiot w liryce Jarosława Iwaszkiewicza i Aleksandra Wata, Katowice 1999.

27 Signifiance means both the process of making sense and the result of this process (in the latter case the meaning is a quasi-synonym of sense). This term was borrowed by works of literary criticism from Lacanian psychoanalysis. Krzysztof Kłosiński proposed translating this term into Polish as „znaczącość”, as it encapsulates activities only within meaningful elements (signifiants), which never refer to the meaningful element (signifié). See K. Kłosiński, Signifiance, „Pamiętnik Literacki” 1999, No. 2, pp. 11-26. 
features can be deployed at all levels of speech: accent, prosodic, lexical, syntactic (distributed in the text like a theme in a story). In this manner signifiants are also syntactic as well as prosodic. The meaning is no longer contained lexically in words alone. In a broader sense, rhythm involves a whole set of prosodic features (layout of accents, intonation), as well as distribution of the syllables in the text and the metric system, if one appears in the text. Thus, analysis is not limited to the semantics of the text itself, but also examines its metre (if there is one), prosody, phonetic structure. Only such rhythm analysis makes it possible to reveal the meaning of the text (signifiance).

Revealing of the significance of the literary text opens up the somatic critique to psychoanalysis, especially to the unconscious theory of the subject. In this way, the project of somatic criticism takes into account both the subject of creative activities (all operations performed on the text by the ego - poetic rules, conventions, normative manners of meaning of literary text) and that which emerges from the areas of unconsciousness.

The outline of the project of somatic criticism can be clearly presented on the basis of texts which correspond to such assumptions. These are works that are intended for the representation of literary experience (first and foremost about the act of writing, the practice of language, speech, which is placed in texts in different registers - the mixing of styles and languages), as well as somatic experience, which poets are attempting to represent in their texts. This is about somatic experience in poetry, and when I say "somatic experience", I am not thinking only about biographical experience (for example illness, pain, erotica), but also about somatic experience of the text and its representation.

I consider the basic principle of somatic criticism to be the coexistence of the body and text. The selection of texts for the subject should be based primarily on this determinant.

In terms of methodology, somatic criticism becomes an eclectic creature, open to a variety of ways of analysing a literary text and to various disciplines: linguistics, semiotics and elements of psychoanalysis. In this way the intended outline of the critique falls into the area of "anthropological poetics", in which the overriding units become texts and their detailed analyses (microanalysis, morphology of the text, thanks to which criticism becomes an almost clinical practice - I think constantly about the equivalence of the sign and the body) lead to the unveiling of the complexity of the subject and assist in getting closer to the truth hidden in texts, without pretending to be completely exhausted and appropriated. 


\section{Rhythm}

"In the beginning was rhythm" - the famous phrase of the German musician and composer Hans Guido von Bülow, constantly recurring in various statements from music history and also in statements about rhythm ${ }^{28}$. So - as Bülow wanted in the beginning was not the Word, but rhythm. This is not just an impressive rhetorical figure or some aphorism persistently repeated by tradition. It will be easy to see this in the following part of the argument.

Rhythm as the basic operational concept of somatic criticism is directly linked to the category of the subject - equally the subject of the speaker and the reader. "There is no subject" says Jacques Derrida, "without the signature of rhythm, in us and before us, before every image, every discourse, before the music itself" 29 . It is exactly rhythm, just like the Derridian shibboleth, that makes it possible to cross borders between these entities. Also, thanks to rhythm it is possible to move from body to body, a kind of metensomatosis - transmutation of one body to another, the wandering of the body, physical reincarnation ${ }^{30}$. Dying in the record, the body is revived exactly thanks to rhythm. The body emits rhythms and signs, it is the source of life and immortality. Rhythm becomes the intermediary between the writing body and the reading body.

For years I have been dealing with the issues of rhythm, and now I would like to go back to them again and link them to the project of somatic criticism. Looking at various works that deal with issues of rhythm, I would like to re-examine my former positions, complement them, and refer to newer works that were created in the twenty-first century.

A return to the issues of rhythm is a return to the beginning of the twentieth century and to some intriguing but somewhat amusing places for the contemporary book reader. Stanisław Mleczko's ${ }^{31}$ study Serce a heksametr czyli gieneza metryki poetyckiej $w$ związku $z$ estetycznym kształceniem się języków, szczególnie polskiego came out in Warsaw in 1901. This work came out 81 years earlier than the book by the outstanding French expert on rhythm issues, Henri Meschonnic.

28 See J. Derrida, Introduction: Desistence, [in:] P. Lacoue-Labrathe, Typography. Mimesis, Philosophy, Politics, Cambridge-Massachusetts 1989, p. 31. See also: A. Walker, Hans von Bülow. A Life and Times, Oxford 2009, p. 7.

29 J. Derrida, Introduction: Desistence, [in:] P. Lacoue-Labrathe, Typography, op. cit., p. 31.

30 The idea of metensomatosis (métensomatose) was brought up not long ago by Jean Derrida. See J. Derrida, La naissance du corps (Plotin, Proclus, Damascius), Paris 2010.

31 S. Mleczko, Serce a heksametr czyli gieneza metryki poetyckiej w związku z estetycznym kształceniem się języków, szczególnie polskiego, Warsaw 1901. 
Meschonnic, writing his monumental dissertation about rhythm did not know this book, which is a shame, as many of Mleczko's theses also coincide with those which we find in the works of the author of La rime et la vie - here, obviously, in a much broader sense, enriched with extensive research experience, expanded systematically over decades in the twentieth century. Mleczko's work is dedicated to "Poets and our naturalists", and the discussion about versology, the theory of poetry is supported by knowledge from the "natural sciences" (anatomy and physiology of the heart). On the cover page of this dissertation we find a concise four-point description of the thematic areas to be addressed: "1. Uniformity of human rhythm; 2. Physiological aesthetics of rhythm; 3. Development of euphony in Polish speech; 4 . Scientific prosody of our verse". No matter what the disadvantages (the weakness of presented theses, the lack of effective investigation and stronger argument), and even simplifications (anthropophonic rhythm as "innate", "natural", but flowing in speech "from the soul") of this hundredyear-old work, it must be admitted that it contains incredible potential, refers to phenomena which, in literary studies of the twentieth century and also today, occupy an extremely important place. Mleczko is unable to clearly name and define many phenomena which were taken up after him by other researchers equipped with linguistic and literary criticism tools which developed during the twentieth century, but his legitimate forebodings, as well as completely innovative theses, cannot be underestimated. The premise of this book is about: "intuitive arousal of the aesthetics of sound" (p. XI), and also that "the educational analysis of vain prosodic formulae in poetic texts can only introduce a certain bitterness into the sphere of our sensitivity" (p. XI) - Mleczko's special utterance of these words could be Meschonnic's ironic statement taken from his Critique du rythme: „la métrique est la théorie du rythme des imbéciles”32. In Wykaz główniejszych myśli i spostrzeżeń $w$ tej pracy zawartych there are, amongst others, two such points:

1. Rhythm is the anthropophonic expression of human speech, especially excited and animated, and therefore it is revealed in poetry, and in a greater or lesser idealization is its essential ingredient. 2. We seek the essential artistic genesis of rhythm in in the subject, not in the object; the groundwork, or shaper, which determines rhythm in our activities and our works, let us also search for them within us, not outside. So, maybe in our breathing, maybe in the beating of our hearts ... ${ }^{33}$

32 H. Meschonnic, Critique du rythme..., p. 143.

33 Ibidem, p. XV. Emphasis - A.D. 
These fragments can be juxtaposed with the quasi-poetic fragment of the closing statement of Meschonnic's book of over seven hundred pages: "Speaking of rhythm, I'm talking about you, you speak, the problems of rhythm are your problems" ${ }^{\prime 34}$.

Versological research significantly developed and spread in Poland in the interwar years, and some of the work in this area was pioneering on a global scale (I am thinking particularly about Franciszek Siedlecki). Karol Wiktor Zawodziński distinguished rhythmicity from metre in his works in the field of Polish versification. In defining rhythm, however, he referred to the old etymology of the word, which associated it with the regular movement of the seas:

The Greeks, continually having the sea in front of their eyes, were able with their faithful aesthetic instinct to feel the kinship of the order in their lives with the order which constitutes a condition of aesthetic activity $[\ldots]^{35}$

The regularity, repetition and aestheticism, adopted by Zawodziński as the basic categories of describing rhythm ultimately led to the fact that metre was identified with rhythm. The same is true of Kazimierz Wóycicki's work, in which he binds rhythm with metre and gives it a mimetic character ${ }^{36}$, and Siedlecki's:

So we call meter a "specialised form" of rhythm (Richards), namely rhythm based on unambiguous expectation of exact repetition, a completely regular continuation of elements determined in a certain way, on stabilisation in a body experiencing a permanent, schematic but clearly unified psychophysiological "image" of a flowing stream of stimuli. ${ }^{37}$

The description of versification systems of poetry is not difficult when it focuses first on metrics and repetition. The biggest problem in the system description proposed by Polish structuralism is free verse. The difficulties are much smaller in the case of syllabic, syllabo-tonic or tonic verse, but they appear in the case of free verse. The difficulties are not resolved by the free verse typology presented by Dorota Urbańska ${ }^{38}$, and this was determined by the development of Polish poetry in the late twentieth century and in the twenty-first century.

34 Ibidem, p. 715.

35 K.W. Zawodziński, Studia z wersyfikacji polskiej, Wrocław 1954, p. 17. Emphasis - A.D.

36 K. Wóycicki, Forma dźwiękowa prozy polskiej i wiersza polskiego, Warsaw 1960, pp. 70-72.

37 F. Siedlecki, O rytmie i metrze, [in:] idem, Pisma, Warsaw 1989, p. 137. See also T. Kuryś, Rytm. Z dziejów terminu i pojęcia, [in:] Wiersz. Podstawowe kategorie opisu, part 1: Rytmika, ed. J. Woronczak, Poetyka. Zarys encyklopedyczny, ed. M.R. Mayenowa, vol. 2, Wrocław 1963. In the same volume we find a description of rhythm made by M.R. Mayenowa (Podstawowe kategorie opisu wiersza).

38 D. Urbańska, Wiersz wolny. Próba charakterystyki systemowej, Warsaw 1995. 
They are not resolved by the excellent dissertation by Witold Sadowski Wiersz wolny jako tekst graficzny ${ }^{39}$. The issues of rhythm are discussed in this work in a separate chapter, and the researcher uses conventional definitions of this phenomenon, explaining such behaviour with a desire "to maintain conceptual linkage with the versological tradition" ${ }^{\prime 0}$. This premise is supposed to explain the fact that it does not refer to Émile Benveniste's famous work. Indeed Benveniste's text has nothing to do with verse, but the fact is that he was basically inspired by poststructural versological reflection, and exactly the works of Henri Meschonnic and Julia Kristeva to which I will refer in the later part of the argument. Further, the etymological basis of Benveniste's reflection is inspiring to this day and not only for contemporary versologists but also for musicologists, as we will see a little later. Meschonnic proposed a definition of rhythm, which does not break the traditional order, which widens the idea itself, which brings many new comments to versology that can be checked not only through French-language literary material, but also Polish. The conceptual distinctions, which Sadowski highlights, are present in the work Critique du rythme and many others, in which the matter of rhythm is crucial for the whole argument. This is not therefore a simple concept - as Sadowski states- "about the general esthetic rank", but a legitimate tool for examining poetic and prose texts, as shown by numerous analyses undertaken according to the principles set out by the author of Pour la poétique.

The difficulty with the description of free verse is, of course, the absence of regular standards, but can it be said that in its absence this type of poem is devoid of rhythm? - in no way can this be done.

Rhythm is a phenomenon of great importance in every type of human activity and is still constantly, at least in the Polish context, poorly used in the description of literary texts (both poetry and prose), while having a great influence on their formation and reception.

The twentieth century brought many rhythmic metamorphoses in poetry. It is enough to draw attention to the fact that in a certain period of development in Polish poetry (and not just Polish!) lines written with regular metre disappeared, and if such texts are to be found, it is only rarely, always for some purpose, and the reader may be sometimes surprised by regularity in a poem, by its anachronistic shape. Innovations were already introduced by futurism and the avantgarde (but they were prepared much earlier, as shown by Lucylla Pszczołowska in her work Wiersz nieregularny), and after the Second World War regular verse

39 W. Sadowski, Wiersz wolny jako tekst graficzny, Cracow 2004.

40 Ibidem, p. 179. 
almost completely disappeared, giving way to the so-called free verse in which the border between poetry and prose is often blurred (perhaps this is a certain "natural" characteristic of the evolution of poetry, and the traditional approach to this problem, taking into account that division is at least unjust?). With the rise of free verse regular metrics developed through literary tradition disappeared, and with increasing frequency rhyme also disappeared, but this does not necessarily mean that rhythm is lost with them as well. In the end it is always present in literary work, whether we are dealing with poetry or prose, and it is always a differentiating element, different in each poet or prosodist, a specific signature of the subject, undergoing metamorphosis throughout the course of every writer's creative work and each of their pieces.

The method of examining literary texts on the basis of their rhythmic form is not new and has been used by many scholars of both poetry and prose. Amongst the most interesting in this regard are the analyses of romantic poetry made by Czesław Zgorzelski ${ }^{41}$. His search often goes beyond traditional metric analysis (although he himself performs them with the utmost meticulousness and perfection) and goes towards grasping the individual qualities of poetic expression, which are often very difficult to describe and before which science is helpless. According to Zgorzelski, some rhythmic phenomena, for example "modulation of intonation", "tone intensity", "breaking of the cadence", can also decide about "disrupted reaction of the subject" 42 . In his works Czesław Zgorzelski very closely examines the issue of rhythm, separate from metre, and associated with the arrangement of syllables in the literary text, with intonation systems. This is quite similar in the works of Stanisław Balbus (I am thinking in particular about his analyses of Czesław Miłosz's verses), who wrote that:

A pattern modeling the outward appearance of poetic expression emerges from the disposition of the psychosomatic unit, and therefore constitutes an organic component of the subconscious part of the creative psyche... ${ }^{43}$

Roman Ingarden, before the war, pointed to the multilayered formation of literary text and emphasised the validity of the "linguistic sound layer": "The linguistic

41 Cz. Zgorzelski, Liryka w pełni romantyczna, Warsaw 1981. See also I. Opacki, Mówione rytmem. „Zadymka” Juliana Tuwima, [in:] idem, Mówione wierszem, Katowice 2004, pp. 192-213.

42 Cz. Zgorzelski, Liryka..., p. 113.

43 S. Balbus, „Pierwszy ruch jest śpiewanie” (O wierszu Miłosza - rozpoznanie wstępne), [in:] Poznawanie Miłosza. Studia i szkice o twórczości poety, ed. J. Kwiatkowski, Cracow 1985, p. 471. Emphasis - A.D. 
sound layer", he wrote, "remains in the memory rather in the form of an echo of characteristic rhythms or other sound marvels of a higher order"44.

The notion of rhythm, apparently obvious and unambiguous, is traditionally combined with a set of formal features of verse; however, in many theories the issue of subjectivity is closely related to rhythm and it is claimed that the subject is most strongly indicated in the text exactly through rhythm. Rhythm belongs to a group of ideas, like "text" and signifiant, which in structuralism had meaning which was unambiguous, final and - it seemed - unquestionable. Henri Meschonnic, in the course of an extensive critique of the notion of rhythm ${ }^{45}$, does something similar to what Roland Barthes did with the notion of text which was unmistakable in Roman Jakobson and Yuri Lotman, and also in the early work of Barthes himself, in poststructural thought, however, it has lost its obviousness. Meschonnic's concept of rhythm also corresponds to the term "trace", introduced by Jacques Derrida.

An outstanding etymology of the idea of "rhythm" was presented by Émile Benveniste in his dissertation La notion de rythme dans son expression linguistique ${ }^{46}$. The concept of "rhythm" has come to the Western dictionary from Greek, through Latin. The Greek rytmos [ $\rho v \theta \mu$ oúc] was one of the key words of the Ionic natural philosophers. Rytmos is a noun formed from the verb rein [rein], which means 'to flow' The etymological analysis undertaken by Benveniste shows that rytmos, from the moment of its appearance until the Attic period never meant "rhythm", was also not a word for the regular movement of waters; on the other hand, it meant a distinctive form, a proportional figure, a layout. Benveniste wrote:

$\rho v \theta \mu o s$, according to the contexts in which it is given, designates the form in the instant that it is assumed by what is moving, mobile and fluid, the form of that which does not have organic consistency; it fits the pattern of a fluid element, [...] It is the form as improvised, momentary, changeable. ${ }^{47}$

The term "rhythm" was made more precise by Plato, who still used rhythmos in the sense of a distinctive form, system, proportion. Here, innovation was based

44 Compare R. Ingarden, Formy poznawania dzieła literackiego, „Pamiętnik Literacki” 1936, No. 1, p. 186. Compare also Ingarden's classical work $Z$ teorii dzieła literackiego. Dwuwymiarowa budowa dzieła sztuki literackiej, [in:] Problemy teorii literatury, ed. H. Markiewicz, Wrocław 1987, pp. 7-54.

45 H. Meschonnic, Critique du rythme....

46 É. Benveniste, La notion de rythme dans son expression linguistique, [in:] idem, Problèmes de linguistique générale, Paris 1966, pp. 327-335. See The Notion of "Rhythm" in its Linguistic Expression, [in:] Problems in General Linguistics, transl. M.E. Meek, University of Miami Press, Miami 1971, pp. 281-288.

47 Ibidem, pp. 285-286. 
on relating this concept to the form of movement that the human body completes in dance, and the pattern of figures through which this movement is transformed. The philosopher linked rhythmos with metron and subordinated this concept derived from music to the laws of numbers. The form was determined through measurement and reduced to sequence. It was Plato who finally established such a concept of rhythm (connected to repetition) which is most often used today. The first philosopher who took up the issue of the difference between rhythm and metre in music was a pupil of Aristotle, Aristoxenus, who created a work dedicated to rhythm and metre - the only extant part is titled Elementa rhythmica.

Benveniste's analysis indicated the complexity of the etymology of the word "rhythm", which resulted in the creation of a kind of "rhythm" myth, compared to the regular movement of sea waters. The verb rein, from which the word rytmos came, means 'flow', but the sea does not flow. Rein never defined the sea and rytmos was also never used to describe the movement of the waters. As a consequence of the erroneous etymology of "rhythm", all attempts to define this concept are always based on emphasising regularity and repetition ${ }^{48}$.

48 The New Encyclopaedia Britannica introduces a clear distinction between the rhythm of music and the rhythm of poetry, defining the second as "the patterned recurrence, within a certain range of regularity, of specific language features, usually features of sound". The author emphasises the difficulty of defining a concept, indicating repetition as its characteristic feature, and ultimately reduces the term to the fundamental distinction between poetry and prose (The New Encyclopaedia Britannica, vol. 10, London 1991, pp. 33-34). Encyclopaedia of Poetry and Poetics does not contain an entry at all for rhythm. On the other hand, it refers to prose, metre and the distinction between prose and poetry. John Anthony Cuddon in his dictionary of literary terms indicates that rhythm can occur both in poetry and in prose. Rhythm, in his opinion, is the movement marked by the accent and non-accented syllables and their period of duration. Cuddon, based on the traditional definition of this concept, claims that rhythm in a poem depends on the metric pattern and is regular, while in prose may be regular or irregular. Immediately the question arises as to why rhythm must be regular in a poem, and not in prose, and why it depends on the metric pattern. What should be done with poems in which there is no metrical pattern? After all, it cannot be said that there is no rhythm in them (J.A. Cuddon, The Penguin Dictionary of Literary Terms and Literary Theory, London 1991, p. 798). Henri Morier's Dictionnaire de poétique et de rhétorique, on the other hand, includes the following definition of rhythm: "a return to a fixed point at more or less equal intervals" (H. Morier, Dictionnaire de poétique et de rhétorique, Paris 1975, p. 933). Morier introduced certain modifications to the definition of rhythm in the reissue of his dictionary in 1989: "in opposition to meter, rhythm [...] tends to break habit, causes surprise by displacement of the accent, combination of accents or by separating phrase from meter". About metre he states: "metre is 
Repeatability associated with the word "rhythm", which is emphasised in many definitions (from different fields and disciplines), leads to erroneous recognition of an historical and anthropological specificity of speech, and consequently to the establishment of an analogy between cosmic-biological and historical orders, which is the order of speech.

Based on Benveniste's analysis, particularly concerning the difference between metre and rhythm (metre and rhythm opposed), an in-depth analysis based on music has been made by Christopher F. Hasty, starting from the following statement: "If we restrict musical rhythm to metre, pattern, and proportion, we feel that something essential has been left out of account"49. This same path is followed by Derek Attridge in his textbook working out Poetic Rhythm. An Introduction, combining the idea of rhythm directly with the body as that which produces it and which represents a physical medium:

Rhythm is a patterning of energy simultaneously produced and perceived; a series of alternations of build-up and release, movement and counter-movement, tending toward regularity but complicated by constant variations and local inflections. ${ }^{50}$

The route taken by Benveniste is also followed by Pierre Sauvanet, an excellent researcher into the issues of rhythm, who presented his position in works published at the turn of the twentieth and twenty-first centuries ${ }^{51}$.

It is impossible to reduce rhythm to a pattern or to proportions, because something important is always lost in such simplifications. If there is metre in the text, there is, of course, repetition and regularity, but there are also various modulations and deviations. These are the most interesting objects of rhythm analysis in my own project.

calm, and rhythm pathetic". A similar definition is given by Ch. Baldick in The Concise Oxford Dictionary of Literary Terms (Oxford-New York 1991, p. 190). It highlights the difference between rhythm and metre and defines this first concept as a "less clearly structured principle". The same principle of repetition is exposed in Stownik terminów literackich (M. Głowiński, T. Kostkiewiczowa, J. Sławiński, A. Okopień-Sławińska, Stownik terminów literackich, Warsaw 1998, p. 493). As can be seen, most definitions are based on emphasising repetition and regularity, even Morier's definition, which is the only one noted in the bibliography to Benveniste's article, but without the consequence for the final shape of the concept of "rhythm".

49 C.F. Hasty, Meter as Rhythm, New York 1997, p. 3.

50 D. Attridge, Poetic Rhythm. An Introduction, Cambridge 1995, p. 3.

51 See P. Sauvanet, Le rythme grec, d'Héraclite à Aristote, Paris 1999; P. Sauvanet, Le rythme et la raison. Rythmologiques, vol. 1-2, Paris 2000. 
The distinctness of rhythm and metre is particularly important in the theories proposed much earlier by Henri Meschonnic ${ }^{52}$ and Julia Kristeva. Metre is frequently identified with rhythm, superimposed on each other, driven by the principle of regularity, equivalence, symmetry. A review of various theories of rhythm shows that there is no definitive position on this notion and that it is always historically determined. As rhythm is unpredictable, it constitutes "internal necessity [nécessité intérieure]" 53 , and so it cannot be equated with metre. In the traditional view metre is a signal of poeticness, a means to "deautomisation" of language (as in the Russian formalists or works of the Prague school). If rhythm is treated as a subcategory of the phonological level it is ordered by metre. Meschonnic maintains that rhythm is not in itself metric. Depending on history and the writing situation it can be metric or non-metric. It may therefore accidentally coincide with regularity, which is a cultural, traditional condition. Rhythm goes beyond metre, which is absolutely predictable and meets our expectations. Rhythm is the opposite - it is unpredictable. Metre is discontinuous, countable, and rhythm is continuous and non-countable.

For Meschonnic rhythm does not require the simultaneous existence of metre, but if it appears in the text it then forms part of a set of rhythmic features,

52 Amongst H. Meschonnic's works, to which I refer most often, note should be made of the already mentioned Critique du rythme...; La Rime et la vie...; Politique du rythme. Politique du sujet, Lagrasse 1995. Broader discussion of Meschonnic's theory can be found in the following papers: G. Dessons, La Théorie du rythme d'Henri Meschonnic. Introduction à la poétique. Approche des théories de la littérature, Paris 1995; S. Capello, Le réseau phonique et le sens. L'interaction phono-sémantique en poésie, Bologna 1990, pp. 111-115; L.M. Bourassa, Rythme et sens. Des processus rythmiques en poésie contemporaine, Montréal 1993; P. Suter, Rythme et corporéité chez Claude Simon, „Poétique” 1994, No. 77. The last two works confirm the methodological effectiveness of Meschonnic's theory in the case of analysis of poetry (Bourassa) and prose (Suter); G. Bedetti, Henri Meschonnic: Rhythm as Pure Historicity, "New Literary History" 1992, No. 23. Practical application of Meschonnic's theory and method of textual analysis at the turn of the twentieth and twenty-first centuries entered the following works: T.V.F. Brogan, Rhythm, [in:] The New Princeton Encyclopedia of Poetry and Poetics, ed. A. Preminger, T.V.F. Brogan, Princeton 1993, pp. 1066-1070; A.F. Aviram, Telling Rhythm. Body and Meaning in Poetry, Ann Arbor 1994; Close Listening, ed. Ch. Bernstein, Oxford 1998 - the collective book, in the introduction to which Charles Bernstein puts particular emphasis on the distinctness of metre and rhythm, and also highlights the importance of prosody in the formation of rhythmic processes. In this book Marjorie Perloff also refers to Meschonnic's works in her text After Free Verse (pp. 89-90); D. Evans, Rhythm, Illusion and the Poetic IdeaBaudelaire, Rimbaud, Mallarmé, Amsterdam-New York 2004.

53 H. Meschonnic, Critique du rythme..., p. 85. 
something of the nature of "accompaniment". When there is metre in a verse, it is described in the same way as the other rhythmic features contained in the composition. The definition given by Meschonnic is as follows:

I define rhythm in speech as an order of features, through which the linguistic and paralinguistic signifiants (particularly in oral communication) create specific semantics (which I call meaningfulness) different from lexical denotation, in other words, prompt new values typical solely for a particular discourse. These features might occur in all levels of speech: accent, prosody, lexis, syntax. Together, these levels form paradygmatism and syntagmatism, which disestablish 'level' as a concept. Contrary to popular reduction of 'meaning' to lexis, meaningfulness derives from the whole discourse, each consonant, each vowel, which according to paradigm and syntagma only reveal themselves as a series. This makes signifiants not only syntactical, but also prosodical. 'Meaning' is no longer a domain of words. In a narrow definition, rhythm is accentual, contrary to prosody - the order of vowels and consonants. According to a broad definition, usually used here, rhythm includes prosody, and in speech - also intonation. Combining the meaningfulness and meaning of discourse into one realm - rhythm in itself orders the sense of discourse. Sense is a consequence of the subject's activity, therefore rhythm organises the subject as a discourse in its own discourse and through its own discourse. ${ }^{54}$

In Meschonnic's definition rhythm is described not in formal categories but is treated as "organisation of sense" in literary text. His analysis is worked out in two planes: syntagmatic (analysis of "contrasts of rhythmic sequences") and paradigmatic (identity of rhythmic sequences, series of - prosodic chains, prosodic figures - reflections, consonant echoes; recurrences - returns which are arranged transversally in the text, crosswise). A consequence of the two-channel analysis is the dialectic of the same and the other, wherein the same cannot be reduced to metre. This is not some abstract formal structure, but an associative process generated by reflections between signifiants, which introduce transversal relations of meaning, in this way creating a model of movement that organises reading.

According to some theories of poetry, sounds can have the character of motifs, they can form sense. Meschonnic believes that in literary works phones create kinds of networks linked by association. The process of association itself is transversal,

54 Ibidem, pp. 216-217, translated from the Polish translation by Adam Dziadek. It is worth mentioning here that Meschonnic's concept of rhythm and subjectivity in a way corresponds to the tendencies of cognitivism in linguistics, tendencies that restore a central position to the experiencing subject in the description of both the discourse and the linguistic system itself, thus accentuating the subjectivity of speech, the anthropocentrism of language (compare the works by A. Wierzbicka, Jezyk, umyst, kultura, Warsaw 1999, and also Językowy obraz świata, ed. J. Bartmiński, Lublin 1990 and Profilowanie w języku i w tekście, ed. J. Bartmiński, Lublin 1998). 
translinear and does not take place in order of succession (a project of anagrammatic reading of text postulated by de Saussure - in his view poetic language creates the possibility of secondary meaning, added to the original words, departing from de Saussure's paragrammatic concept of reading texts associated with psychoanalysis - Kristeva, and also "series" and Meschonnic's "prosodic figures").

According to this associative concept of reading, it is not possible to attribute value solely to the sense itself, because value is connected with the functioning of the discourse in its entirety. Only this assumption about reading, based on the transverse and dynamic process of association makes it possible to consider the phonetic organisation of the text as a component co-creating rhythm.

The whole sphere of sound is extremely important for the rhythmic and meaningful functioning of a work. Contrary to the conventional view, which completely rejects the motivic character of the sign, considering all phonemic phenomena, pragmatics, logic of discourse, linguistics, the language plane should be replaced with the discourse plane and we should concentrate on its functioning. In this perspective, the text ceases to be a static structure, becomes a dynamic process and undergoes constant transformation. Phonetic systems combined with other levels of expression form the text system.

The analysis should therefore follow the phenomena of contrast and consequence, and the phenomena of transversal, translinear returns of defined phonetic elements. Significance is shaped for example by a series of the most commonly occurring phones that give a "differentiation effect" or consonant reflection (echo) $)^{55}$. In subsequent repetitions one word is invoked by others. Such an analysis takes into account the frequency of occurrence, order and position of the phones in order to determine in this way the meaning of the expression, which is connected to memory, orality and the set of perceptual, affective and cognitive abilities of the subject.

The rhythm of the text as the fusion point of two different temporal experiences (the subject who writes and the subject that reads) is presented with help from the concept of trans-subjectivity, which is based on a series of repeated enunciations (ré-enonciations). Rhythm updates the subject, its temporality. The poem goes from "I" to another "I", is a discourse in which one can recognise the past of others.

55 The typology of consonant echoes taken by Meschonnic is based on the division proposed by D.I. Masson, Sound-Repetition Terms, [in:] Poetics. Poetyka, ed. K. Wyka, vol. 1, Warsaw 1961, pp. 189-199. 
Meschonnic tries to defend the position of the subject, defining its boundaries again. A subject is something that goes beyond the individual, and therefore must become formless, independent of the organisations that set its centres, which impose boundaries and restrictions.

Rhythm, albeit understood somewhat differently, is also a key idea for Julia Kristeva and her theory built on the base of Lacanian psychoanalysis, de Saussure's theory of anagrams and the theoretical concepts of the Russian formalists (particularly these last two sources bring Kristeva closer to Meschonnic, who used much, first and foremost, from Boris Tomaszewski's work Metrika, O stichie).

Repartition and the increasingly frequent occurrence of certain phones or groups of them within a given text, in the researcher's opinion, exert an effect alien to the properties of the natural language. The phones then lose their phonematic character (they lose their distinctive features) and "come closer to" phonetics, and together with this to the articulating body (speech organs, impulses). Kristeva states that this return to phonetics indicates a retreat to a certain "pre-phonemic state". Each of these repeating phones is

a carrier of sems in such a way that the morpheme or lex to which these phones belong is dispersed [around the text], and in this way the semanticized phone is directed to form a certain semantic constellation, to which all the lexemes containing that phone belong. ${ }^{56}$

Then the phones acquire some new distinctive qualities and establish accordance applications between sems. Common, simultaneous operation of both "mechanisms": phonological and containing the mechanisms of "accordance" or "application" of repetitive phones

opens the normative use of speech on the one hand to the body and the semiotic chôra, which are hidden and suppressed, and on the other to the multiplicity of displacements and condensations produced by strongly ambivalent or polymorphic semantics. ${ }^{57}$

In Kristeva's view the arrangement of phones forms a kind of network and rhythmic systems, through which engagement in the act of writing may be revealed:

56 J. Kristeva, La Révolution du langage poétique, Paris 1974, p. 222, transl. into Polish A. Dziadek. The English translation of this text was abridged and these quotations have been translated from the Polish version of the text. All quotations from Kristeva referring to the idea of chôra come from the same work. See also J. Kristeva, Le sujet en procès, [in:] eadem, Polylogue, Paris 1977, p. 57. See also Plato, Timaeus, transl. with Introduction Donald J. Zeyl, Hockett Publishing Company, Indianapolis, Cambridge 2000.

57 J. Kristeva, La Révolution..., p. 222, transl. A. Dziadek. 
As the symbolic function emanates from the semiotic chôra, the impulsion is reduced, disciplined, organised into unity, which is the unity of the speaking subject. ${ }^{58}$

The idea of chôra was taken by Kristeva from Plato's Timaeus, which is an extremely loaded text, as it relates to the myth of Atlantis and the birth of the world. While discussing her theory in La Révolution du langage poétique, Kristeva explained borrowing the ontological category of chôra from Plato, claiming that it serves the purpose

to denote an essentially mobile and extremely provisional articulation constituted by movements and their ephemeral stases. We differentiate this uncertain and indeterminate articulation from a disposition that already depends on representation, lends itself to phenomenological, spatial intuition, and gives rise to a geometry. ${ }^{59}$

According to Kristeva, chôra "as rupture and articulations (rhythm), precedes evidence, verisimilitude, spatiality, and temporality" ${ }^{\prime \prime}$. Kristeva places special emphasis on vagueness, even the "mystery" of the word. When interpreting Plato, she speaks of instability, uncertainty, and continuous becoming of chôra. This is to be a container (réceptacle - gr. upodocheion), which is also defined as space and opposed to reason. Chôra is unnameable, unlikely and a bastard (which should rather be expressed as "no-one's"). According to Kristeva, the only similarity that is acceptable in the case of chorra is similarity with the vocal or movement rhythm. Chôra is a place freed from the burden of meaning, it is not a sign because it does not represent anything. This concept was initiated by Kristeva into the psycholinguistic theory of the subject:

The theory of the subject proposed by the theory of the unconscious will allow us to read in this rhythmic space, which has no thesis and no position, the process by which signifiance is constituted. Plato himself leads us to such a process when he calls this receptacle or chora nourishing and maternal, not yet unified in an ordered whole because deity is absent from it. ${ }^{61}$

This unnameable, bastard, unclaimed is to be anticipated in relation to naming, in relation to the One, to the father - and as a consequence he is connotated as a mother. In the light of Kristeva's reflections the subject appears as a kind of result of an effect of crossing semiotics (chôra) and symbolism (language),

58 Ibidem, pp. 224-225, transl. A. Dziadek. See also English translation M. Waller : Revolution in Poetic Language, Columbia University Press, New York 1984.

59 J. Kristeva, Revolution in Poetic Language, transl. M. Waller, Columbia University Press, New York 1984, pp. 25-26.

60 Ibidem, p. 26.

61 Ibidem. 
it is a consequence of their dialectical coexistence. The subject - in Kristeva's opinion - is always simultaneously symbolic and semiotic, and each significant system that it produces cannot be exclusively semiotic or symbolic, because it is marked by both modes of meaning. In Kristeva's terms, the body-related rhythm and rhythmic constraints are pre-symbolic and function before the process of meaning begins.

These two concepts of rhythm inherent in the subject form a counterbalance to structuralist ideas, and they are also proposals for the description of literary texts, which by means of analysis would make it possible to reach areas of meaning so difficult to grasp in traditional reading methods.

Rhythm presented in this way allows us to depart from the metaphorical ideas of narrative poem: melody, lyricism, etc. They are of course very close to the definitions of rhythm that appeared in the nineteenth and early twentieth centuries, in which rhythm was most often equated with metre. I am talking about, for example Józef Elsner's Rozprawę o metryczności i rytmiczności języka polskiego, szczególniej o wierszach polskich we względzie muzycznym ${ }^{62}$, in which the subsequent analyses of the "rhythmical metre" in poetry (the author's term) are closely related to music (rhythm as the basis for distinguishing poetry from prose, rhythm as "whole array of tones and [...] their place in time", rhythm is the passing of time while pronouncing a phone; metre in poetry is a bar in music) ${ }^{63}$. This dissertation is supplemented by Kazimierz Brodziński's commentary and "eight-syllable" poems with detailed metrics written before each text ("pleasant metrical slavery - Brodziński writes - almost like a musician awakes, maintains and raises the mood"). In the work by Ludwik Jenike $O$ znaczeniu rytmu $w$ poezji rhythm is subordinate to nature and its regularity unambiguously implies a regular measure: "The need for a certain commensurability of movement and sound of all kinds, the tendency to capture them in some kind of a fixed systematism, seems to be inborn"64. This is similar with Antoni Małecki's definition, which places emphasis on the smooth and harmonious aesthetics of reception of poetry:

62 J. Elsner, Rozprawa o metryczności i rytmiczności języka polskiego, szczególniej o wierszach polskich we względzie muzycznym, Warsaw 1818.

63 See the beginning of Elsner's essay.

64 L. Jenike, O znaczeniu rytmu w poezji, a mianowicie o rytmiczności języka polskiego, Warsaw 1865. 
We call rhythm in general the consequences after oneself, or the loosening of the accented phones, which, if repeated in a constant and consistent order, makes pleasure for the ear and creates the rhythm that poetry requires. ${ }^{65}$

In turn, in the definition of the word "rhythm" from Karłowicz's dictionary we read: "the harmonious succession of long and short syllables, or stressed and not stressed, giving the verse lyricism" ${ }^{66}$. Jan Nepomucen Łoś in his essay Wiersze polskie w ich dziejowym rozwoju undertakes a review of rhythm in Polish poetry from the Middle Ages to the early works of the Skamander poets and distinguishes rhythm based on three principles: metric, accent and phonic, constantly based however on regularity and repetition, and also links it with music and dance, stating that

Rhythm and rhyme - these are the two most important features of modern poetry; to them the third characteristic is musicality, melodiousness, the lyricism of the poem. Unfortunately, it is impossible to say what this really means: whether stylistic features or, as some argue, a certain manner of ordering consonants, sounds, but above all vowels, like musical elements. ${ }^{67}$

Łoś defines any departure from the regularity of the rhythm as a "rhythmical mistake", "broken rhythm", "rhythmical defect", "rhythm frequently not maintained", "disturbed rhythm", "arhythmicism", "varied rhythm", "most unruly rhythm" - all this, in his opinion, destroys the rhythmical order and disturbs the pleasure of receiving the poem. In the view of Henryk Życzyński, the matter is as follows:

Poetic rhythm, whether manifested in beautiful prose or in a poem, is for the poet not primarily a form of experience but of formation. What comes before is the mood, the ferment, undetermined impulse, and rhythm is only the creative fiat, which brings out beauty. As such, it is a compulsion, a discipline, but at the same time the only condition that can give aesthetic value. ${ }^{68}$

Speaking of rhythm, he repeatedly emphasises regularity, but also mentions a "shadowy variety" (this term is unclear in his argument). Życzyński considers Julian Przyboś and Jan Brzękowski to be poets seeking to revolutionise Polish

65 A. Małecki, Gramatyka języka polskiego szkolna, Lwów 1906, p. 264. In Gramatyka języka polskiego większej of 1863 Małecki wrote: "[Rhythm] This is like some kind of step-by-step dance, whose already more or less noisy stamping has the feature (in our language), that the second or the third less noisy stamp is followed by a louder one".

66 J. Karłowicz, A. Kryński, W. Niedźwiedzki, Słownik języka polskiego, vol. 5, Warsaw 1909, p. 798.

67 J.N. Łoś, Wiersze polskie w ich dziejowym rozwoju, Warsaw 1920.

68 H. Życzyński, Problemy wersyfikacji polskiej, part I: Rytm poetycki, Lublin 1934, p. 32. 
poetry, and points out that the innovations in their poetry are mainly limited to stylistics and the manner of creating images, but the rhythmic side, in his view, is neglected and undefined in an appropriate way. Nothing could be more erroneous, but it was only possible to come to such a view many years later.

\section{Anagrams}

Rhythmical analyses consistent with these concepts can also be linked to the anagram developed by Ferdinand de Saussure. Literary criticism research in Poland has almost completely ignored de Saussure's anagrams (exceptions are the work of Edward Balcerzan, Władysław Panas, Wincenty Grajewski and Ireneusz Piekarski, and also my own ${ }^{69}$ ), and also pushed aside the psychoanalytic approach that followed the theory of anagrams, which significantly influenced the formation of Polish versology (I am thinking here first and foremost about the inherent prosody lined with the work of anagrams undertaken by French researchers in the context of psychoanalysis, in Polish structuralism, however separated and often reduced to issues of "phonic instrumentation" and "sound structure"; the frequently issued Zarys teorii literatury gives clear witness to this: versification here is separated from the issues connected to prosody). In Kristeva's theory (and to a lesser degree in Meschonnic's theory) the combination of the theory of unconsciousness with versology gave surprising results in the search for meaning and above all in the ways of generating it.

Research about de Saussure's anagrams continue in France to this day. Recently, two excellent works have been published by Pierre-Yves Testenoire ${ }^{70}$, who has been conducting extensive research in the field for years: Ferdinand de Saussure à la recherche des anagrammes and Anagrammes Homériques - a collection of de Saussure's complete notes about this subject prepared by the researcher. In the first of the indicated books, the author proposed a historical and epistemological

69 E. Balcerzan, Pełno rozwiśleń i udniestrzeń, [in:] idem, Oprócz głosu. Szkice krytycznoliterackie, Warsaw 1971, pp. 29-44; W. Grajewski, Jak czytać utwory fabularne?, Warsaw 1980, p. 106; W. Panas, Tajemnica siódmego anioła, „Roczniki Humanistyczne” 1999, vol. XLVII, No. 1, pp. 9-26. See also I. Piekarski, Narcyzm, anagram, sygnatura. Uwagi o pewnej obsesji (i literaturze), [in:] Psychoanalityczne interpretacje literatury: Freud, Jung, Fromm, Lacan, ed. E. Fiała, I. Piekarski, Lublin 2012, pp. 313-334; A. Dziadek, Anagramy Ferdynanda de Saussure'a - historia pewnej rewolucji, „Teksty Drugie” 2001, No. 6, pp. 109-125 (in an expanded version reprinted in: A. Dziadek, Na marginesach lektury. Szkice teoretyczne, Katowice 2006, pp. 30-58).

70 P.-Y. Testenoire, Ferdinand de Saussure à la recherche des anagrammes, Limoges 2013; F. de Saussure, Anagrammes Homériques, ed. P.-Y. Testenoire, Limoges 2013. 
analysis of the anagram search by de Saussure. Testenoire clearly underlined that the Genevan linguist used the word "anagram" as a masculine word (le angramme), whereas in traditional linguistic usage anagram functions in French as a feminine word (lanagramme) and is the name of a traditional stylistic figure ${ }^{71}$. The conclusions of this work clearly show that de Saussure's search is not a product of some interpretative delirium, the madness that was once attributed to him by Michel Deguy (details below), and also do not contradict the general linguistic principles outlined in his Course in General Linguistics. Saussure treated anagrams as a versification principle, but also as an "another source of rhythm"72, which from my point of view is extremely important and will find its consequences in many places in this dissertation in detailed analyses.

The Swiss linguist for years secretly researched the anagram phenomena in saturnic poetry, Homeric epics, Vedic poetry, Lucretius, Seneca, Horace, Ovid, and also neo-Latin poetry. The researcher also expanded the project to prose texts, recognising that they have similar phenomena to those which appear in poetry. He only revealed details of his search to selected friends (for example Antoine Meillet, to whom he wrote a letter about this matter). The notes only saw light of day in 1964, when Jean Starobinski first made a selection of 99 notebooks and announced fragments in "Mercure de France"73. In the same year, in Cahiers Ferdinand de Saussure letters to Antoine Meillet were published - the first of these concerned anagrams and was soon commented upon by Roman Jakobson $^{74}$. After this first publication Starobinski's next articles literally poured out describing various aspects of the same problem: Les mots sous les mots [The words under the words] in 1967, in 1969 in a special number of "Tel Quel” Le texte dans le texte [Text in text], in the same year the article Le nom caché [Hidden name] appeared and finally in 1970 Ferdinand de Saussure, lecteur de Lucrèce

71 P.-Y. Testenoire, Ferdinand de Saussure..., p. 19.

72 Ibidem, pp. 58-64. Emphasis - A.D.

73 J. Starobinski, Les Anagrammes de Ferdinand de Saussure, textes inédits, „Mercure de France" 1964, No. 1204, pp. 243-262. The following works, among others, contain broader discussion of de Saussure's concept: J. Starobinski, Les mots sous les mots. Les anagrammes de Ferdinand de Saussure, Paris 1971; J. Baetens, Postérité littéraire des Anagrammes, „Poétique” 1986, No. 66, pp. 217-233. It is worth mentioning here also another interesting discussion by Johnathan Culler and titled Anagrams and Logocentrism, see J. Culler, Saussure, Glasgow 1976, pp. 106-117.

74 R. Jakobson, La première lettre de Ferdinand de Saussure à Antoine Meillet sur les anagrammes, [in:] idem, Questions de poétique, Paris 1973, pp. 190-201. This commentary was first published in the journal „L'Homme” 1971, No. XI, pp. 15-24. 
[Ferdinand de Saussure, reader od Lucrece $]^{75}$. Starobinski collected all of these works and published them in the book Les mots sous les mots. Les anagrammes de Ferdinand de Saussure in 1971.

The consequence of Starobinski's next publications was "Saussure's second revolution", as one of the critics ${ }^{76}$ called it, though not without completely justified doubt. The reception of de Saussure's notes spread as if towards two opposing poles, for on the one hand, they indicated the possibility of extending the field of poetic research (for example Thomas Aron, quoted earlier, and also Roman Jakobson and Julia Kristeva), and on the other hand, the madness that must have possessed de Saussure was even spoken about (for example Michel Deguy perceived two contradictory poles in de Saussure's works - the rationalism of Course in General Linguistics and the "madness" of his notebooks ${ }^{77}$ ). Deguy was of course correct (but certainly not about Saussure's madness), as he proved that the rationalism of the theory of the sign contained in the Course ... is in conflict with the "non-realism" contained in the notebooks.

Already in the second half of the sixties Saussure's notes began to produce interesting analytical works of various literary texts, as well as theoretical concepts of poetic language, especially related to semiotics.

De Saussure's anagram is a phonetic anagram, not a letter anagram, which is usually a graphic anagram. In linguistic analyses, this is primarily about reading and describing the structure, as well as the various combinations of sounds rather than letters. It emphasises the special characteristics of anagrams, which define the names accordingly: "anaphora" (anaphonie), "hypogram" (hypogramme) and "paragram" (paragramme). Thus, the researcher described the phenomena much more widely than the traditionally understood anagram, yet the name he adopted has never been changed and since Starobinski's first work we speak of

75 J. Starobinski, Les mots sous les mots: texts inédits des Cahiers d'anagrammes de Ferdinand de Saussure, [in:] To honor Roman Jakobson, Paris 1967, pp. 1906-1917; idem, Le texte dans le texte, extraits inédits des Cahiers d'anagrammes de Ferdinand de Saussure, „Tel Quel” 1969, No. 37, pp. 3-33; idem, Le nom caché, [in:] L'analyse du langage théologique, le nom de Dieu, ed. E. Castelli, Paris 1969.

76 Compare T. Aron, Une seconde revolution saussurienne?, „Langue Française” 1970, No. 7, pp. 56-62.

77 M. Deguy, La folie de Saussure, „Critique” 1969, No. 260, p. 22. The title of this discussion of two of Starobinski's articles presenting Saussure's notebooks may be viewed in retrospect as too exaggerated, as is the criticism contained in it. This is well demonstrated by Testenoire's work, which I mentioned above. 
"Ferdinand de Saussure's anagrams", thus identifying the problematic circle indicated by the Genevan linguist.

The real turn began only a few years after the publication of analytical fragments of de Saussure's notes by Starobinski. It turned out that anagramatic reading of literary texts associated with psychoanalysis ${ }^{78}$ and semiotics gives theoreticians of poetic language extraordinary opportunities. I point out that this turn led to a paradigm shift within literary criticism structuralism, created the foundations of modern theory of text and initiated so-called poststructuralism (although in France itself no one called it that and do not call it that).

Roman Jakobson was one of these poetic language researchers whose was absolutely fascinated by the notebooks. The linguist thus spoke about de Saussure's so-called phonecising poetics:

[...] most of the ancient poems analyzed by Saussure seemed to reveal to him manifold anagrams alluding to the names of people involved in the plots of these poems; thus these sounds functioned simultaneously in the text proper and in the paratext, and thereby endowed the latter with "une seconde façon dêtre, factice, ajoutée pour ainsi dire à l'original du mot" (quoted by Starobinski: p. 31). If Saussure's manuscripts of this massive work had not been spumed for many decades as supposedly "futile digressions", the international struggle for a science of poetics would have received beneficial incentives (cf. Benveniste 1964: 109-114). ${ }^{79}$

Jakobson read the notebooks with great care (in the aforementioned commentary on Saussure's letter to Meillet he called them "an unusual document" p. 196) and indeed was not mistaken about their "beneficial inspiration", for the effects of which it was not necessary to wait long. According to Jakobson, the research undertaken by the Genevan linguist revealed the "universally polyphonic and polysemic" nature of poetic language, and at the same time opposed "the empty and embarrassing idea of rationally reliable poetry" ${ }^{\prime 0}$. De Saussure's comments inspired many of Jakobson's analyses of poetic texts, which appreciated their value and the possibilities they gave, and the phenomena he discovered in Baudelaire's texts or Khlebnikov's anagrams, already mentioned, which he explained convinced of the motivic character of the sign.

78 Jean-Michel Rey placed de Saussure's anagrams in the context of psychoanalysis in discussing Starobinski's Les mots sous les mots. See J.-M. Rey, Saussure avec Freud, „Critique” 1973, No. 309, pp. 136-167.

79 R. Jakobson, L.R. Wough, Sound Shape of Language, Mouton De Gruyter, Berlin-New York 2002, p. 224.

80 Idem, La première lettre..., p. 200. 
One of Jakobson's analyses focuses on four poems from the cycle Les Fleurs $d u$ mal, which bear the same title Spleen, where the linguist puts a special emphasis on the last one ${ }^{81}$. The title Spleen is in this poem at the same time a "theme word", as there are numerous allusions to this word in the text. Allusions are written into the text using anagrams based on multiple repeats of the phone groups $s p$, $p l$ and groups of spri.

Saussure's search had a great influence on the formation of structuralism in France. In one of her works Julia Kristeva directly stated that de Saussure had, in his own way, discovered dissemination, and therefore spreading out and in so doing opposing his own concept of the sign ${ }^{82}$.

The phenomenon of constant phonetic recurrence appearing in poetry or prose can be described in many different ways. However, regardless of the terminology used, it is always about calling the secondary meaning or the secondary text that is hidden under the surface of the text being examined. This secondary text is not always related to the author's intention, because it may flow from the subconscious.

It is my intention here to emphasise one of the most important consequences of de Saussure's theoretical discovery. The appearance of anagrams in literary texts can be explained in many different ways, and at least two of them depend on how the subject of expression is treated in a given text. Well, if we understand the subject as cogito, then anagrams are related to intentionality, are intended, teleological, completely consciously written into a given literary text, and this is an indisputable truth. If the subject is understood in psychoanalytical terms, then the presence of an anagram in a literary text, felt even intuitively, allows the unconsciousness of the text to be unveiled. If we only sense the presence of anagrams intuitively, then the anagram is ultimately recognisable and this fact alone entitles us to talk about it.

It must be noted here once again that the problem of unconsciousness of anagrams was never definitively excluded by de Saussure, and waited to be finally resolved in Kristeva's work, as well as other researchers focused in the journal "Tel Quel”. In research in the field of theory of literary text conducted by Kristeva among others, the matter of intentionality has been put aside. Since we are already touching on this issue, it is worth recalling here that intentionality itself is a kind of construct that is based on the reader's hermeneutic conduct. If we

81 Idem, Une microscopie du dernier „Spleen” dans „Les Fleurs du mal”, [in:] idem, Question de poétique, Paris 1973, pp. 420-435.

82 J. Kristeva, L'engendrement de la formule, [in:] eadem, Séméiotikè. Recherches pour une sémanalyse, Paris 1969, p. 292. 
do not assume the intentionality of the anagram, then the hermeneutic conduct itself is no longer sufficient and it is impossible to describe this phenomenon using the tools offered by hermeneutics, they do not suit the problem so expressed.

\section{Contexts}

A fundamental change in the understanding of poetic rhythm has taken place in futuristic and avant-garde texts - here one has to look for basic modifications of the poetic language, which will shape later poetic works. It was just here that in Poland a kind of "revolution of poetic language" took place, which has influenced the poetic awareness of successive generations. In recent years there have been several papers that are particularly important for our discussion, so they require a brief consideration.

One of the most important monographs that clearly shows the nature of the changes that have taken place in futurism is the book by Beata Sniecikowska "Nuż w uhu”? Koncepcje dźwięku w poezji polskiego futuryzmu ${ }^{83}$. The significance of this monograph lies primarily in the fact that it is a fundamental rethinking and description of futurism, which has never been undertaken on such a scale before. And it really is as the author wrote at the beginning of the work: "No one to date has proposed a broad, holistic approach to viewing the problem of sound formation of futurist poems" (p. 45) ${ }^{84}$. Over five hundred pages of text we find a number of questions focused on the issues of sound instrumentation (and not only because the author raises questions where the cases are usually considered to be obvious, unworthy of investigation - a case very well described in this essay is the problem of Polish poets following Khlebnikov), all the discoveries from surprising lines of microanalysis, comparative experiments, whose effectiveness rather demands the question: how could anyone not have come across this yet? Conceived in meticulous readings of Jasieński, Stern, Wat, Młodożeniec and Czyżewski, Śniecikowska's discoveries captivate with simplicity and rarely leave doubts. The book is an attempt at answering a very important question that the author asked at the end: "What is left of Futurism?". Sniecikowska answered the question thus: "modern perception of the language of literature", and there is no way to disagree with this answer. If we discover Futurism and - more broadly the avant-garde today, when the humanities have been equipped with a variety of

83 B. Śniecikowska, „Nuż w uchu”? Koncepcje dźwięku w poezji polskiego futuryzmu, Wrocław 2008.

84 Ibidem, p. 45. 
research tools, it becomes evident that without the literature that posed difficult questions at the beginning of the twentieth century, there would have been few actions in linguistics, literary scholarship, and also in philosophy.

Significant in this work seems to be the transition from the Young Poland musicality to the sound structures of futuristic poetry. This is a very important research gesture that emphasises the connection with literary tradition, but also more importantly - points to the revolutionary nature of the futurists' poetic language. It was their poetry that finally made it impossible to further explore musicality, the melodiousness or the lyricism of the poem. The sphere of sound of this poetry reveals the supplementary meanings hidden in it, and the author is fully aware of this.

Sniecikowska seems to follow the thought pronounced by Roman Jakobson in his Six Lectures on Sound and Meaning: "Speech sounds cannot be understood, delimited, classified and explained except in the light of the tasks which they perform in language" ${ }^{\prime 5}$. And indeed in this book it is such, because all analyses of "sound tissue" (an apt definition often appearing here) reveal (or try to reveal) its strict functionalism and grow out of conviction about the communicative nature of language. The researcher attempts to systematise, organise and classify sound phenomena found in futuristic poems.

While analysing the sound structures in futuristic texts, it cannot be said that all the sound phenomena in poetry of Polish futurism (or in any other poetry) are based on concepts. One must add to this the sphere of unconsciousness, the issues of paragrammatism (de Saussure, Kristeva), signifiance, and finally intratypography (Meschonnic) ${ }^{86}$ and issues of rhythm and layout of text on the page closely related to this.

The next work that I would like to pay attention to is a thorough monograph of the phenomenon of consciousness of rhythm shaping modern Polish poetry prepared by Joanna Dembińska-Pawelec ${ }^{87}$. The dissertation presents the problem based on texts of poets representing different generations of poets quite rightly, as such an overview of various poets and worldviews shaped in diverse social and historical conditions makes it possible to grasp and reliably analyse the meaning of rhythm for poetic texts. This is a thorough monograph,

85 R. Jakobson, Six Lectures on Sound and Meaning, transl. from French J. Mepham, The MIT Press, Cambridge-Massachusetts 1978, p. 109.

86 See Chapter 8, Section 1.

87 J. Dembińska-Pawelec, „Poezja jest sztuka rytmu”. O świadomości rytmu w poezji polskiej dwudziestego wieku (Miłosz - Rymkiewicz - Barańczak), Wydawnictwo Uniwersytetu Śląskiego, Katowice 2010. 
because it also reaches into the history of the very concept of rhythm, to the beginning of the word in language in general, shows its centuries-long evolution in various poetics and concepts of poetic language up to the modernist turning point, and presents the multifaceted nature of rhythm. This is especially true in the meticulous analysis of specific texts. It must be emphasised that the concepts of poetic rhythm discussed here and its theories built up by poets and literary scholars are subjected to critical review in this book. Here this is not about simple reference, but critical discussion, made with distance by the researcher carefully looking at the evolution and metamorphoses of various concepts and positions.

In order to realise the meaning of the notion of "rhythm" in modern art and thought in general, there is a brief discussion of the presence of this phenomenon in philosophy (amongst others Bergson, Nietzsche), in music, in visual art, in theatre, which constitutes the basis for further reflection about rhythm in literature. This general approach is well described and makes it possible to realise the essential meaning of rhythm in the nineteenth- and twentieth-century theories of art and literature ${ }^{88}$.

The author extensively discusses the theme of rhythm taken by Bolesław Leśmian, the Cracow Avant-garde and Skamander poets. It is a pity that there was not even a short passage about rhythm from the futuristic poets (I am referring to both the Cracow Futurists and the Warsaw Futurists, modelled strongly on the achievements of Russian futurism and the Russian formalist school - this matter was highlighted by Anatol Stern and Aleksander Wat already in the almanac „Gga”). The analyses focus on texts by Czesław Miłosz, Jarosław Marek Rymkiewicz and Stanisław Barańczak. For each of these poets, the issue of awareness of rhythm seems obvious, but no one before Dembińska-Pawelec addressed this question or discussed it in such a thorough manner.

As for Miłosz, the problem of consciousness of rhythm implies three interdependent fields: rhythm in the external world, rhythm as a component of poetics

88 I agree completely with the author on the matter of "non-metrical rhythm" of the Cracow Avant-garde. I would just like to add that Zdzisław Łapiński once drew attention to the poetry of Julian Przyboś with regard to similar issues in the short sketch „Psychosomatyczne sa moje wiersze”. (Impuls motoryczny w poezji Juliana Przybosia), „Teksty Drugie” 2002, No. 6, pp. 9-17; the original version of this text was published in English in 1989 (Motoric Impulse in the Poetry of Julian Przyboś, transl. B. Lewandowski, "Literary Studies in Poland" 1989, No. 21, pp. 67-79). Rhythm closely linked to the prosody is an extremely important ingredient in the poetic language of Przybos's poetry, which I tried to show years ago on the basis of an analysis of the so-called cathedral poems (I mean the book Stulecie Przybosia, ed. S. Balbus, E. Balcerzan, Poznań 2002, pp. 289-304). 
of texts and rhythm as a link with metaphysics. The most interesting of the texts so far written about Miłosz's poem was the one by Stanisław Balbus - „Pierwszy ruch jest śpiewanie". (O wierszu Miłosza - rozpoznanie wstępne). This is a great starting point, but the researcher went in a different direction than Balbus because she reconstructed and interpreted Milosz's thinking about rhythm: rhythm is connected with Nature, revealing what is singular and unique, but also what is closely related with tradition. In the symbolic plane, rhythm in Miłosz's lyrics (or, more accurately, the "symbolic meaning of the rhythm of blood") links his works to the texts of William Blake and above all Oskar Miłosz. In the final reading, emphasis is placed on the mystical aspect of rhythm and its relation to the apocatastasis repeatedly applied in various writings. The aforementioned text by Balbus, which thoroughly analyses the versification systems in Miłosz's poetic texts and puts up a loud thesis on "disposable systems", became one of the important points of departure, but ultimately the author chose another way of trying to interpret Miłosz's poetic and non-poetic expression, which gave the effect in the form of innovative interpretations.

Also in Rymkiewicz's case, the key descriptive concept is rhythm. The author shows the evolution of the poet's rhythmical consciousness: from the early phase of "oniric rhythm" to conventional practices in which rhythm gains the value of a "broker" in intertextual relations (rhythm, if I well understood the researcher's intent, in a certain sense triggers voices of the past, voices of the Baroque and Romanticism). Transience and dying, danse moriendi (waltz and ländler) indicating the shape of the poetic form and monotonously repeating the basic rhythms of human existence inevitably associated with death.

Finally, in Barańczak, rhythm introduces a kind of distinction and division into interior and exterior - the second is submerged in permanent chaos, and even makes it impossible to experience the eurythmy, the first remains, which, albeit fleetingly, in a fluid, rhythmicised structure of a single and unique text makes it possible to experience harmony, order and oneness.

This book is of great importance for Polish research on poetic rhythm at a time when traditional tools of poetic analysis are more and more often put aside and fall into oblivion. Working outs in the form of a shaky system contribute to this, because the analyses of metre itself, just the versification systems, if they are not related to interpretation, do not affect its formation, they are simply boring and cognitively worthless (Mleczko wrote about this a long time ago). DembińskaPawelec drew attention to a very important aspect of the functioning of rhythm its senso-creative properties, which in no way can be related only to the regularity of metre, meaning the matter cannot be reduced to mere metrics, to some 
versification system, especially when it comes to the fact that consciousness of rhythm is so strongly developed that the poets themselves comment upon it in their metatextual or paratextual statements, create their own theories and make them an integral component of the creative act.

Based on the aforementioned theoretical bases, I would like to propose reading the texts of several poets: first, the most somatic, the author of Wiersze somatyczne - Aleksander Wat; further - Joanna Pollakówna in whose poetry the sphere of poetic sound plays, as we shall see, an important role, influencing the rhythmic form of these texts; as well as two other very different "somatic poets": Eugeniusz Tkaczyszyn-Dycki and Edward Pasewicz. The selection of texts is strongly differentiated here - this is about poets belonging to different generations, ascribed by critics to different poetics, but who are also exceptionally original poets. A separate chapter is devoted to the body of that extraordinary form of poetry, the sonnet, placing emphasis on all the modifications, transformations and changes which it has undergone, and the popularity which it continues to enjoy today. The book closes with a chapter devoted to somatext (understood differently from feminist literary critique, as it is in the context of cognitive science) and the phenomenon of intratypography - about the relationship between word, image and rhythm, which I analyse through the examples of visual poetry, as well as the book editions by Franciszka and Stefan Themerson. 



\section{Somatic writing, touching sense - Aleksander Wat}

In any somatic criticism project we could not miss out Aleksander Wat, the author of Wiersze somatyczne, but not just for he was a writer in whose texts somatic writing and experience are ubiquitous. Starting work on the subject of somatic criticism years ago, I began with Wat ${ }^{89}$. It is necessary to take a careful look at his texts, also archival and never before published, for this purpose, with particular emphasis on his 1919 debut - the poem JA $z$ jednej strony $i J A z$ drugiej strony mego mopsożelaznego piecyka - already in this debut work elements of somatic writing are clearly visible, which will develop with strength in the later work of the author of Ciemne świecidło. Already in Piecyk and in some early poems there was presence of somatic experience, which shaped the manner of expression, particularly the sensitivity to sound and semantics of words and their roots in history.

Let us start with a completely different text, from the never quite written autobiography. I mean the short text entitled Poczatek autobiografii. A fragment of this was previously published in London „Wiadomości” in $1968^{90}$. "Wiadomości" announced the excerpt of this extraordinary text, which was no doubt decided by the publisher himself. In the Wat archive in the Beinecke Library (Yale University) it is located in a file containing a grey envelope, further described by Ola Wat: „Wiersze dane do druku przez Olę W. do «Wiadomości» w r. 1968" ["Text given for printing by Ola W. to «Wiadomości» in 1968”], and still more complementary information, also written by Wat: „Tekst znaleziony w papierach pośmiertnie (niedrukowany)"91 ["Text found in papers posthumously (not printed)"]. It is worth including here in its entirety (the fragment published previously I have indicated in italics):

My earliest memories of myself: opposite my cot there was an old pendulum clock. The clock's face with its mysterious symbols and the movement of two arms were the first indicators of immobility and the mystery of movement. The difference in speed between the two

89 Compare A. Dziadek, „Soma” i „sema” - zarys krytyki somatycznej, [in:] Literackie reprezentacje doświadczenia, ed. W. Bolecki, E. Nawrocka, Warsaw 2007, pp. 69-82; A. Dziadek, Wstęp, [in:] A. Wat, Wybór wierszy, Wrocław 2008, BN I, No. 300, pp. XV-XXII.

90 A. Wat, bez tytułu, „Wiadomości” 1968, No. 14(1149), p. 2.

91 All archive materials I have cited are in the Beinecke Rare Book and Manuscript Library (Yale University, New Haven, USA) and bear the name Aleksander Wat Papers and the signature GEN MSS 705. 
arms gave me the first intuition of relativism and the impetuosity of their movement demonstrated the playfulness of continuity and mutation. The pendulum was more importanta copper disc with a sharp spike at the end and with sharp edges. The complete regularity of its movement was like a threat to me. I do not recall now what effort of my baby mind was involved in seeing a threat in the mere invariability and regularity of the there-and-back pendulum swing. I probably did not think how, but I knew for sure and awaited it with terror of the strength, cohesion and hostility which can never again be reproduced, that the pendulum would reach me like the arm of my older brother over the silly few meters and that the sharp disc would slit my throat, the weakness, softness, vulnérabilité, and fragility I knew from the inside better than anything else and throats have fascinated me ever since.

I will not mention the acoustic implications. The consistent and uniform tick-tock and the rarity and non-uniformity of the hourly chiming, which I awaited with bated breath, gave me the sense of two dimensions of time: one determined and determining and the other, the fortuitous one, entering life like a miracle, like a breakthrough or a fast inverse square root? - weekdays versus holidays, crowded background versus individual act - and because this alternation repeated itself every day I became convinced that the individual act belongs to a greater determined system of a higher importance, that the I like and the I want to repeat myself force nature to repeat them. Obviously, these are considerations on my first experiences (quarum) of the world, but in my sixty-seventh year of life I am not absolutely sure whether the ability to contemplate I then possessed, had not later been lost quite quickly in the years of oblivion, censorship or quarantine, as they are described by Freud.

I was born on May 1st 1900, at the very beginning of May. The day and the year - the first of the new century, remained in my memory as one of those significant facts, that are perhaps not as much symbolic as figurative, in the Auerbachian mimesis sort of sense: happening at an intersection of two realms - one real, historical, exact and another metahistorical, transcendental. From a vulgar angle, I jokingly took the First of May parades to my credit, and because until recently the first of May was usually also a bright and sunny day, the first proper day of spring in fact, and, despite my depressive disposition, it used to forecast a happy future.

This is an unusual text which could be a kind of complementary text to the poem with the incipit ${ }^{* *} W$ czterech ścianach mego bólu..., as well as an extraordinary supplement to the interpretation of the poet's birthday. Recalling childhood memories after many years in the "attempt at autobiography" - surprising, saturated with somatic experience, filled with a specific kind of body phraseology. It is a seemingly minor fact, which could perhaps have been one of those deciding about his whole life and shape of his work. Somatic experience, which is very precisely defined here: weakness, softness, frailty, additionally a word from French vulnérabilité ("defencelessness", "weakness", but also "sensitivity”), accompanied the poet from early childhood and certainly had a great influence on the shape of his texts. Later on, this was added to by an illness of a somatic nature, which intensified the experience itself and its expression in subsequent texts. 
One could look at this fragment in the context of the psychoanalytic conception of Le Moi-peau, proposed by Didier Anzieu ${ }^{92}$. Le Moi-peau (the concept is translated into Polish in two different ways: „ja skórne” [“me-skin”] and „egoskóry" ["ego-skin"]; the first variant seems much better) is a mental image that the child ego uses in the early stages of development to represent himself as an ego, which is based on the experience of the surface of the body. Hence the psychosomatic relationship between the mind and the skin. This process that begins in the foetus and which strengthens in the early stages of the baby's development, and is always associated with sensory experiences, has a significant impact on the sensory sphere, and consequently also on the shape of thought, perception and reasoning (the transition from Moi-peau to Moi-pensant) ${ }^{93}$. So did this episode described after years, a childhood memory attached to the cycle of late poetry not affect the form of thoughts expressed by binding speech? In this case this is not about touch, but about the way in which this experience is perceived and processed, the fact that it has fallen so deep into the writer's consciousness that it is difficult not to regard it as extremely important.

The second part of the Poczatek autobiografii refers to his date of birth and represents its interpretation. In the famous essay titled Shibboleth: For Paul Celan, as a true meditation about the date, Jacques Derrida noted the remarkably meaningful words referring to this: "date works like a first name" of this statement seems obvious when we give the date of Aleksander Wat's birth: 1 May 1900. Indeed, it would be difficult to undermine Derrida's words. To repeat, 1 May 1900, the turn of the twentieth century and Workers' Day! This is more than just a symbol ${ }^{95}$, something that determines life and work, constitutes their indissolubility and places the creator in history and in an extensive network of social relationships. The date of birth of the author of My Century is like a shibboleth to his life and work, a shibboleth which is necessary to learn to access this extraordinary work.

If an iconoclastic character is attributed to Wat's creative work - as Małgorzata Baranowska and Tomas Venclova did - the act of changing the name of Chwat's father to Wat is extremely significant and impinging, I think, on the whole work of the author of Policjant. It involved not only a rebellion against culture, against information overload and various messages that culture brings and burdens

92 D. Anzieu, Le Moi Peau, Paris 1995, p. $61 \mathrm{ff}$.

93 D. Anzieu, Le penser. Du Moi-peau au Moi-pensant, Paris 1994.

94 J. Derrida, Szibbolet dla Paula Celana, transl. A. Dziadek, Bytom 2000, p. 19.

95 See T. Venclova, Aleksander Wat. Life and Art of an Iconoclast, Yale University Press, New Haven-London 1996, p. 1. 
young people with (an expression of this rebellion, according to the writer himself, was to be Mopsożelazny piecyk), but it had much deeper reasoning. In Wat's case, it is not a simple change of name, but a break and a rejection of "the name of the father" (Chwat). Transforming "the name of the father" into Wat is certainly not a simple, common rhetorical turn of futurist-iconoclasm ("watt" as a unit of electrical or mechanical power, symbol of the power of electrical current, it is easy to see this reading Miliard kilowatów śpiew Adamów $i$ Ew and the dedication inside: "To Ola this billion kilowatts + Wat"), but, more deeply, it also involves the establishment of a completely new discourse stretched between the sign and the body, consciousness and impulse. Given the rebellious attitude of Wat, this second explanation is more convincing, and the name itself can be an anagrammatic reading to reveal the meaning of this radical gesture that the poet made at the beginning of his creative journey. In the name of Chwat, all consonants are voiceless, and in the name of Wat, the phones regain their voicing. This unvoicing process - let us assume - is unconscious - goes in the opposite direction to semantics, „chwat" means 'chłop na schwał' ["a peasant on a pedestal”], 'zuch' ["a lad"], 'ktoś odważny' ["someone brave"], which emphasises its phallicness. Meanwhile, in semantics it is the opposite - unvoicing $c h$ and $f$, which, by using psychoanalytic terminology, would mean castration. The change of surname causes the cutting off of the unvoiced phone $c h$ and voicing the phone $f: c h / f \rightarrow$ w/at. Going further along lines indicated by psychoanalysis, we see that the name Wat is the name of someone, the name of the inventor, so by cutting off the phone $c h$ - and thus symbolically castrating his father - Wat takes the name of the Other. This is a significant gesture of rebellion, coinciding with the life choices of the writer. Transformation of the surname is not a game or a phonetic play in this case - it is something much deeper here, as de Saussure defined the poet's "anagrammatical activity", and the poet defined himself as "first and foremost, a specialist on phonemes"96. In the case of Wat - as we shall see later - this definition is most appropriate, both in terms of his early poetic texts, and those written in the fifties and sixties.

How should we read and describe Wat's poetry? A difficult task, many books and articles have been written about his work, excellent analyses and interpretations of his work, which enjoys immense interest and is constantly being read as if for the first time. The difficulty of the description results not so much from the fact that so much has already been written about Wat, about the specifics of

96 P.-Y. Testenoire, Ferdinand de Saussure à la recherche des anagrammes, Limoges 2013, p. 277. Testenoire quotes de Saussure's words in one of his letters to Antoine Meillet. 
his work, characterised by a kind of inexhaustibility. Decrypting the text by the author of Ciemne świecidło, the reader quickly constatates that it is a work, as Czesław Miłosz rightly said, growing out of excess:

I realised then that Aleksander's poetry was only a small fraction of a great whole that was constantly forming in him, demanding to be voiced; another part of that whole was his stories - the stories of a witness and a participant that charmed his listeners. ${ }^{97}$

The aforementioned excess has become an intrinsic feature of Wat's poetics (the intent and desire to create a work entitled Wszystko o wszystkim [Everything about Everything]), but also something that restricted the writer. The description of a work that deals with everything would require the application of tools from all corners of knowledge about literature and culture. To write about Wat's poetry - I am making a travesty of the poet's own words - I have to refer to everything. Thus, it might have been, as has been popular recently, an "anthropology of literature", "anthropological poetics" or "cultural theories of literature". But I was looking for something that would be the most appropriate name for the whole of Wat's work. My proposal involves a broad project of reading his poetry texts, I would describe it as "somatic criticism".

Aleksander Wat's poetry corresponds perfectly to the assumptions of this project; it is geared both to the representation of literary experience (mainly about the act of writing, the practice of language, the language that is found in poetry of different registers - the mixing of styles and languages), and the somatic experience, which the poet tries to represent in his texts. This is about somatic experience in Wat's poetry, and when I say "somatic experience", I do not just think of the agonised poet suffering from a painful illness, which we find in so many of his texts, but I also think of the somatic experience of words and texts and their representation.

Konstanty A. Jeleński in the review of the volume Ciemne świecidło identified the point, as I think, which is key to Aleksander Wat's poetry, that is its somatism, the constant presence of the body:

There is one thing Wat did not see in his own works, and this constitutes the originality of his poetry for me: this analysis goes further, is taken more broadly than the ordinary deep probes into the psyche. On his own, Wat discovered what some philosophers and artists have perceived - that the body also has a "subconscious" and that there are unexplored areas (due to the persistent fiction of the "body" and "soul" duality) and, crucial for understanding, what is the biological "personality". 98

97 Cz. Miłosz, Przedmowa, [in:] A. Wat, Mój wiek, London 1981, p. 9.

98 K.A. Jeleński, Lumen obscurum, [in:] idem, Zbiegi okoliczności, Paris 1982, pp. 255-256. 
There is no exaggeration in the claim that the so-called somatic verses could fill an entire anthology, starting with Wiersze somatyczne, through Ode III, finishing with poems such as Skóra i śmierć, Przed weimarskim autoportretem Dürera and many others. Czesław Miłosz also drew attention to the somatic character of this poetry, together with Leonard Nathan when they were preparing the American selection of Wat's poetry: Skóra [With the Skin], like so many other critics (Kazimierz Wyka, Jan Zieliński, Janusz Kryszak, Stanisław Barańczak, Tomas Venclova) $)^{99}$. Analysing the motifs of the body, the skin, so often appearing in the poems, commentators spoke about "disgust for the body" (Lipski), "body meditation" (Jeleński), "thinking with the body, feeling the world through flesh" (Zieliński), "thrust into skin" (Barańczak), "existence and body" (Wyka), "ultimate sacralisation of the skin" (Venclova). Czesław Miłosz made it clear that "attempts to translate skin into words" appeared already in Piecyk and are constantly present in the poetical work of the author of Ciemne świecidło. Wat - in Miłosz's view - tries to speak with skin, not language, and does not refer exclusively to Ode III from the volume Ciemne świecidło, where the word "skin" is repeated 30 times and it is just this which is the somat that organises the whole structure of this text. With Wat, from the very beginning of his creative work, from Mopsożelazny piecyk, it is easy to see what Jean-Luc Nancy called l'expeausition (given in English as skin-show), so the inevitability of movement, separation, deviation, dislocation, departure from one another, but also towards one another - in this original neologism there are two important meanings: „odcieleśnienie" ["off-body”] and „roz-cieleśnienie”100 ["body-spread”] -, this duality of movement of "from" and "to" corresponds well with the declared duality of the subject in Piecyk.

99 With the Skin. Poems of Aleksander Wat, transl. Cz. Miłosz, L. Nathan, New York 1989. See particularly excerpts from interviews of translators included in the selection in the form of a postword, p. 104; J.J. Lipski, Noc ciemna, [in:] idem, Szkice o poezji, Paris 1987, pp. 27-31; J. Zieliński, Spowiedź syna królewskiego, „Twórczość” 1984, No. 3, pp. 77-87; J. Kryszak, Ból mój, mój demon, „Poezja” 1974, No. 7-8, pp. 135-138; S. Barańczak, Cztery ściany bólu, [in:] Pamięć głosów. O twórczości Aleksandra Wata, ed. W. Ligęza, Cracow 1992, pp. 33-48; K. Wyka, Super flumina babylonis, [in:] idem, Rzecz wyobraźni, Warsaw 1959, pp. 413-440; T. Venclova, Aleksander Wat, op. cit., p. 218.

100 J.-L. Nancy, Corpus, transl. R. A. Rand, Fordham University Press, New York 2008, pp. 32-35. This American edition is different from the earlier French one: J.-L. Nancy, Corpus, Paris 2000, pp. 31-34. See also J. Derrida, Le toucher. Jean-Luc Nancy, Paris 2000, p. 301. Derrida describes this idea as „un mot magnifique et nécessaire”. 
Skin is a multisensory organ, a sensual marker of various mental and psychic states, not only connected with physiology or medicine, but also has a deep cultural significance, as Anzieu pointed out in his previously mentioned research, and recently also Steven Connor in his excellent cultural study of this phenomenon entitled The Book of Skin ${ }^{101}$. Anzieu in a decisive manner emphasises the primacy and superiority of the skin (and even the dominance of touch over other senses), considers it the most vital of all sense organs and, based on the findings of medical science, states that a person can live without sight or without hearing, may live without taste or smell, but not touch ${ }^{102}$. Similarly, Anthony Synnott, who calls touch the "first sense" - that which first develops in the foetus ${ }^{103}$.

The problem set out in this way in the form of a metaphor must be developed, as many difficult issues appear and cannot be resolved by Valéry's famous phrase from L'idée fixe ou Deux hommes à la mer: "Ce qu'il y a de plus profond dans l'homme, c'est la peau" or also „nous sommes [...] ectoderme”. What does somaticism mean, carnality, the presence of the body in a literary text? How can this presence be possible?

When we speak of the "corporeality" of Wat's poetry, we often bind it to some extent rightfully (continuous thematic recurrences in many diffuse works) to elements of extra-literary reality, directly to the poet's biography, to the painful illness he was struck by in 1953 and which caused literary writing to become an "auto-bio-grafią cierpienia" ["auto-bio-graphy of suffering"], which concerns both poetry and prose ${ }^{104}$. I will not develop this theme here, which has been addressed so many times by readers of Wat, also by myself, in more depth. I will confine myself to just a few indicators I found in the writer's archive located in the Beinecke Library at Yale University. These are medical documents (descriptions of illness, medical analyses, physician's opinions), journals about how he felt and physiological functions of the organism arranged in the form of tables, medicine boxes written in the poet's hand, as well as moving, daily notes made every day in calendars and agendas (most commonly reduced to short formulae, for example dated 10 February 1964: "Recurrence of pain"; the next day: "depression, droopy"; dated

101 S. Connor, The Book of Skin, London 2004.

102 D. Anzieu, Le penser..., p. 35.

103 A. Synnott, The Body Social. Symbolism, Self and Society, London 1993, p. 156.

104 The illness which befell Wat is described by neurology as Wallenberg's syndrome, more properly lateral medullary syndrome. W. Dudziński, Aleksander Wat opisuje swoje schorzenie neurologiczne, „Wiadomości Lekarskie” 1989, No. 10, pp. 665, 684, $692,702-703$. This article provides an analysis of the symptoms of the illness on the basis of Wat's notes from Dziennik bez samogłosek. 
20 February 1964: "cold, wind, already v[ery] bad"; dated 21 March 1964: "now catastrophic"; dated 29 March 1964: "now hell" and 22 December 1964: "depths of despair" - "hell" and "despair" are the most frequently appearing words; amongst these jottings we also find notes on medical visits and medicines; these are proof of the suffering and the writer's full awareness of the influence of psychosomatic illness on his daily life - his work was born in the shadow of suffering, and his body stamped its indelible stigma on this). The quoted notes are from the Wats' Berkeley stay. At the same time, he made literary attempts related to illness, as for example this work from the cycle Trzy starości:

Three o'clock

He was lying in his warm and peaceful room. He could catch a glimpse of the Pacific Ocean from the verandah. The ocean was everything but peaceful for him - quarrelsome, vicious, forever windblown with cyclones, the beasts of the sea depths, the worst of monsters. The university Arcadia proved rather quiet - he was safe and surrounded by good people. But the goodness... what could it be like, if there are no seasons here? Cushioned, conserved? Can it not develop here like for people and plants elsewhere, in pain and effort and joy and in the rubbish of winter, resurrections of spring, maturity of summer and melancholy of autumn? And still, how good they are despite the lack of seasons!

After an eighth Percodan that day and a second Nembutal that evening, I was just about to crash head-first into sleep, just like a sinking stone. It was one in the morning and my beautiful female neighbours came back in their triumphant limousine with a loudspeaker proclaiming Colville's Glory and laughter in the bushes of plants the names of which I didn't know. The atrocious thwacking of the garage gate, running up the wooden staircase and along the landing, young shouts and a slam of the door. Third, then a fourth Nembutal and a heavy, limp sleep comes - it lasts maybe a minute, perhaps 10 minutes? There goes the door again, slamming, young cries, running on the staircase. I switched on the torch, it was two-thirty. I looked through a vent window - all eyes in a bony face, loose skin distorted in a rage, a dishevelled mop of hair, (I haven't been to a hairdressers for four months), my whole life fits between a sofa and an armchair - and in a croaky, toothless falsetto I shouted Silence!, not being able to find any other English words except for the Shakespearian execration Go you into hell. Silence. And finally in a Polish manner: I wish Sleep! Silence! I wish Sleep! Up against the railing - terror-stricken eyes of two young students petrified with my appearance. ${ }^{105}$

Descriptions of experience of illness are also found in unpublished notes of the writer in the same archive collections ${ }^{106}$. These examples complement in some

105 This work was first published in „Zeszyty Literackie” 2009, No. 108, p. 10.

106 See A. Wat, Notatniki, ed. A. Dziadek, J. Zieliński, Wydawnictwo IBL PAN, Warszawa 2015. 
way all that is known from the poet's late poetry and Dziennika bez samogłosek, and emphatically stress the amount of suffering caused by severe psychosomatic illness. Such an illness could not fail to leave a trace in the poetry he wrote. For sure the author of Dziennika bez samogłosek, Szkiców o Krasińskim (containing a small fragment titled $O$ bólu [About pain]) and dozens of poems in which illness, pain, suffering are expressed explicite, would have no objection to reading with an emphasis on biography. He repeatedly spoke on this issue, for example

I think that the only valid criterion today is the face of the poet, that is his poetic personality and fate, a matter - unfortunately - beyond the poetry itself. The only sure-fire guarantor is sincerity - a moral property. And the price the poet paid for his poems, a matter of biography, which according to critics should be of interest to nobody. ${ }^{107}$

Wat made his painful illness a metaphor for the twentieth century ${ }^{108}$. The subject of Wat's poems are undoubtedly shaped by his personal experience, as evidenced by numerous footnotes of an autobiographical nature as well as fragments of works in which traces of biography are easily identifiable after reading. Moj wiek, Dziennik bez samogłosek or finally the book by Ola Wat Wszystko co najważniejsze..., "Contrary to common rules today," wrote Miłosz, "his poetry is unashamedly autobiographical, it is a stenogram of suffering"109. Here we are dealing with a "psychosomatic discourse", in which illness becomes a work of thought ${ }^{110}$, and the experience of pain penetrates and is scattered through all of the writer's late work. The text of life and the text of literature are intertwined, inseparable.

Speaking of "somatic writing", I want to point out that it is already present in Wat's early texts. Let us take a closer look at Mopsożelaznemy piecyk, in order to discuss the thesis of the links between and the late creativity of the writer ${ }^{111}$. In

107 A. Wat, Dziennik bez samogłosek, edition K. Rutkowski, London 1986, p. 173.

108 Ibidem, p. 22.

109 Cz. Miłosz, O wierszach Aleksandra Wata, [in:] idem, Prywatne obowiazki, Paris 1985, p. 63. Emphasis - A.D.

110 Compare M. Greco, Illness as a Work of Thought. A Foucauldian Perspective on Psychosomatics, London-New York 1998, p. 27.

111 This extraordinary piece by Wat has been attracting many interesting readings. I would like to point out some, in my opinion, of the most important: S.I. Witkiewicz, Aleksander Wat, [in:] idem, Nowe formy w malarstwie. Szkice Estetyczne. Teatr, edition J. Leszczyński, Warsaw 1974, pp. 404-409; M. Baranowska, Trans czytającego młodzieńca wieku (Wat), [in:] eadem, Surrealna wyobraźnia i poezja, Warsaw 1984; M. Baranowska, Transfiguracje przestrzeni w twórczości Aleksandra Wata, [in:] Przestrzeń i literatura, ed. M. Głowiński, A. Okopień-Sławińska, Wrocław 1978, pp. 281-296; W. Bolecki, Od "postmodernizmu” do „modernizmu” 
Coś niecoś... Wat himself indicated the relationship of the poem to his writings written in the fifties and sixties, claiming that in Piecyk it is possible to find "the same melopea, but also topics, sentences even, whole Weltempfuhlung!" - indeed, it is difficult to disagree with the poet's view. According to the author's opinion written after years the purpose of Piecyk was psychotherapeutic, it was supposed to be a psychoanalytic confession of "a disturbed soul, terrified, raising one's self towards death".

Many excellent interpretations have been written about this poem, and furthermore the work has become a source of inspiration for musical composition - a fragment of Piecyk starting with the mysterious name Gindry inspired a composition by Katarzyna Głowicka, who in 1998 created a work for bass and orchestra titled Gindry. However, the purely philological work I have done on the text teaches that it is still an infinite work in which new, previously unrevealed meanings can be explored, making it possible to complete the previous research findings.

What is the situation of this poem? What happens to the speaking subject? How do the rhythms of speech work in it? How are the actual body and body of the text presented in it? Here are some questions that will make possible a whole different reading.

For Wat, Piecyk was a particularly important work, as evidenced by the fact that shortly before his death (between 22 and 30 May 1967) in Ostatni zeszyt he wrote an extensive autocommentary or even attempted an auto-interpreta$\operatorname{tion}^{112}$. He prepared this text with thought to an edition of poetry for the Parisian

Wat (inne doświadczenie), „Teksty Drugie” 2001, No. 2, pp. 29-39; K. Pietrych, W chaosie i nicości. O młodzieńczych utworach Aleksandra Wata, [in:] Pamięć głosów...; J. Płuciennik, Awangardowy „święty bełkot” Wata, [in:] Szkice o poezji Aleksandra Wata, ed. J. Brzozowski, K. Pietrych, Warsaw 1999; W. Panas, „Antykwariat anielskich ekstrawagancji” albo „Święty bełkot”. Rzecz o „Piecyku” Aleksandra Wata, [in:] W „antykwariacie anielskich ekstrawagancji”. O twórczości Aleksandra Wata, ed. J. Borowski, W. Panas, Lublin 2002, pp. 5-22; J. Olejniczak, W-Tajemniczanie - Aleksander Wat, Katowice 1999 (here particularly pp. 108-113); T. Venclova, Aleksander Wat..., pp. 78-109; B. Śniecikowska, „Nuż w uchu”? Koncepcje dźwięku w poezji polskiego futuryzmu, Wrocław 2008, pp. 131-144; M. Kłosiński, Poszukiwanie znamion intymności w „Mopsożelaznym piecyku” Aleksandra Wata, [in:] Intymność wyrażona (2), ed. M. Tramer, A. Nęcka, Katowice 2007, pp. 216-226.

112 Ostatni zeszyt - as named by Ola Wat - is to be found in the poet's archive collection in the Beinecke Library. It is in this in which the handwritten note is to be found Cos niecoś o „Piecyku”. Brulion. This text was first printed in „Zeszyty Literackie” (2007, No. 99) based on a typed manuscript from the archive of K.A. Jeleński from the Muzeum Literatury im. A. Mickiewicza in Warsaw. I also published this in the form 
"Libella”; the volume of Ciemne świecidło from 1968 (the last prepared by the author for printing) contained fragments of Piecyk, as well as fragments of rough notes about it. Writing rough notes, he pointed out clearly in Ostatni zeszyt: "Choose only a few sentences from this. Quite simply Piecyk was écriture automatique and that is why I made small changes (cleaned) $30 / 5$ ". To this he added a description of the changes: "1) I removed grammatical errors; 2) words, which the printer for sure read wrongly; 3 ) abbreviations here and there".

Let us return to Miłosz's words and try to figure out what it means to speak skin instead of language. In Wat, and already in Mopsożelazny piecyk, it is indeed possible to feel particular somatic and semantic tension (this is almost touching the words, touching the sense as Jean-Luc Nancy ${ }^{113}$ would say, writing not as a demonstration of meaning, but rather touching sense), by which I understand both the sensitivity to the meanings of words (multiplying in an uncontrollable way; some meanings bounce off from others, and the whole makes a seemingly incoherent logorrhea, and places even some completely discontinuous word "leak", scattering or unravelling meanings) and the involvement of the body in the act of writing (the body in this work is heavily stigmatised, this is not just about eroticism but also about the deep meaning hidden in the rare and sometimes secretive words interwoven in the text of the poem). The body, or rather, bodies occupy a central place in this poem, but it is significant that they are bodies with illnesses (leprosy, typhoid, scrofulosis), bodies mutilated, raped, tortured, deformed, scourged, overtaken by convulsions, vomiting - the whole extended sphere of repulsive and disgusting physicality (this is something that corresponds exactly to Julia Kristeva’s abjection $\left.{ }^{114}\right)$ : "stinking cripples", "rotting jaws", "endosperm of dead babies", "underarm stink", "pluke on Baronci's nose", "drooling curse of pus", "impossible stink", "I am a walking latrine", "stinking gob of troglodyte puke...", "raping, stringing me up like lingerie...", "gouged bodies", "slowly rising on broken body parts", "instead of eyes flies colonise burntout eye-sockets". Here there are desecrated, defiled or even corrupted bodies. Here there are many descriptions of not only illness of the body, but also mental illness, and their images are accompanied by a vision of the world in disintegration. Here exists a whole gallery of objects and figures taken as if from a cabinet

of an annex in: A. Wat, Wybór wierszy, pp. 292-313. There is also a copy of Piecyk in the Beinecke collection from 1920 with numerous corrections and highlighted fragments.

113 J.-L. Nancy, Corpus, op. cit., p. 16.

114 See J. Kristeva, Powers of Horror. An Essay on Abjection, transl. L.S. Roudiez, Columbia University Press, New York 1982. 
of peculiarities, and all are deformed, surrounded by destruction and decay (similar images of the body and world in disintegration will also appear in Wat's late poetry, Pieśni wędrowca from Wiersze śródziemnomorskie - here the poetic statement is supported by the dissertation by Henri Decugis, Le Vieillissement $d u$ Monde Vivant, which Wat carefully studied, as evidenced by notes in one of his notebooks; a fragment of this book became the motto to the seventh part of Sny sponad morza śródziemnego $)^{115}$.

Items counted in dozens and even hundreds play a great role in this poem, and indeed, as Wat wrote years later, we are dealing with the preponderance of the world of things over the human world. Piecyk is a poem effectively and solidly stitched together by the poet-bricoleur from a heap of junk drawn from the most diverse corners of culture. Next to this, scandalous for its time, is the eroticism that fills the text and constantly returns in new forms.

Wat's writing in the early, but also in the late, period of his career, in many respects, actually resembles the écriture automatique of the surrealists. The poet himself emphasised the fact that his technique of poetic art („automigawka” ["autoshutter"], , autozapis” ["autorecord”] - as he called them himself) overtook the writing model popular a few years after the publication of Piecyk by André Breton. As we found out from Coś niecoś..., the work was written in a "transe [...] with a fever of 39-40 degrees", and also later in trances, which the poet - in accordance with his declaration - was supposed to be ailed with. Although the motto of the whole is a fragment of Baudelaire's Les Paradis artificiels, and in the same work there are also references to De Quincey and his Confessions d'un mangeur d'opium anglais and to Théophile Gautier's La Pipe d'opium, Piecyk is in no way any kind of a narcotic vision, a text inspired by drugs, but a piece written in a different state of consciousness. The subject of the speech is broken up, already divided in the title of the work and cannot be limited to the phenomenon of syllabic "me", understood in two ways: as the real "me" and the fictitious "me", empirical and textual ${ }^{116}$. This breakdown indicates the unconscious - the conscious "me" and the unconscious "me", the "me" that consciously construes the text, according to well thought out norms and rules, and the unconscious "me", entangled in writing according to the rules of intertextuality, where the text is organised on the basis of other texts, which are "prompted" by the unconscious

115 See A. Wat, Notatniki, transl. and ed. A. Dziadek, J. Zieliński. Wydawnictwo IBL PAN, Warsaw 2015, pp. 385-389, 690.

116 See R. Nycz, Tropy „ja”. Koncepcje podmiotowości w literaturze polskiej ostatniego stulecia, [in:] idem, Język modernizmu, Wrocław 1997, pp. 85-116. 
of the subject of the writing. The external words in this text are to a certain degree possible to capture, identify and locate.

This "me and me" could also be described in terms of schizophrenic breakdown of "me" - the divided "self", as Ronald Laing ${ }^{117}$ wanted - one of them has a completely protected ontological status, while the other does not treat reality and its own identity as something entirely self-evident. A person under threat, with a sense of alienation from themselves, creates a "false I", which adapts "false reality" and in this way is to help to overcome despair - in the end, as we learn from the brouillion, Piecyk was supposed to be a manifestation of rebellion against the artificiality of the textual world (a sense of despair and the desire to be freed from the limiting bonds of culture).

The rhythmical form of Piecyk is defined by several factors, rhythm is spread across all levels of speech: the construction of the whole text, its prosody, the notation on the page (type and size of font, italics, majuscules) and also the semantic tension. In the same text a clear metatextual indication is to be found: "The oracles of rhythms were centred on the outlines of words and existences" as we read in the fragment of Męzkość. The whole text is a true explosion of unbridled syntactic systems and eruptions and ferries of a variety of lexical and phonetic effects that stimulate the rhythm that emerges from the intended path of the body.

The poem consists of three parts, and within them there are fragments separated by spaces, paragraphs and titles written in majuscules. We are dealing with text written with a loose narrative relationship, relations between these fragments are based on free associations, sometimes repeated words or larger phrases. In this fragmentary writing parataxis is decisive to meaning, as it is for the rhythm of the whole text.

The very concept of rhythm was of importance in the early stages of the poet's work, as evidenced by the passage from Almanach GGA Prymitywiści do narodów świata $i$ do Polski: "Poetry: we leave rhyme and rhythm as they are first and the fertilising". Many years later this was refined and defined by the poet in O przetłumaczalności utworów poetyckich:

Correct meter is essentially only brought about by specialists. Generally it is worth recalling here:

a) rhythm marks the boundary - elusive - between poetry-poetry and prose-prose

b) it has its own physiological aspect of the amplitude of breath and pulse

117 R. Laing, Podzielone ja, transl. M. Karpiński, Poznań 1999. See The Divided Self: An Existential Study in Sanity and Madness, Penguin 1960. 
c) there is a metronome of meaning hidden in its layers. If the original rhythm of the poem definitely violates established patterns of national poetry metrics, the translator should second the poet in that; in other cases it should adopt the author's meter to the prosody of his own language, most approximately. ${ }^{118}$

In this passage Wat introduces a clear distinction between "rhythm" and "metre", linking the idea of "rhythm" with physiology (breathing and pulse), but also ascribing to it an important, as I emphasise, feature of prioritisation in relation to meaning ("is a metronome of sense in its latent layer"; emphasis Adam Dziadek), which refers to the deep structure and genotext (in Kristeva's understanding: phenotext and genotext, the first constitutes a phenomenological surface of a statement, a linguistic phenomenon and refers to the structure of meaning; the second is related to the functioning of the signifiant, and so is a unit of meaning that cannot be reduced to sense and turn into a sign, which refers to meaning productivity), to the unconscious. Rhythm influences the translingual system and modifies the phenotext. Throughout the text the presence of "rhythmic constraint" is revealed (contrainte rythmique - J. Kristeva's term), which is based both on the phonic network of the text and on phrasal chanting (and thus on a pre-syntactic matrix) that are revealed and are perceptible in intonation.

The semantic tension, which is a very important element of the rhythm of this text, is related to the sensitivity to so-called biology and the history of the word, and if we look at Piecyk in just this way, all the statements about the non-sensical nature (gibberish) of this extraordinary text become quite simply unfounded, and the work itself appears just as an inexhaustible masterpiece dazzling with dozens of shades of meaning, like a facade decorated with noble stone.

Said sensitivity to semantics and the sound of words was already present in his futuristic texts, and particularly in Piecyk, which can be defined as palimpsest unambiguously open to the "text world" - it is not a mannered work, although in places it is of course overly stylised, but concentrated on texts and the phrases and words that make them up. It is written on other literary texts (intertexts which are part of this are not limited to De Quincey, Baudelaire, Rimbaud or also Ramòn Lullo) and philosophical and other texts of culture, it is a product whose intrinsic principle is intertextuality, opening the reader to a vast space of meanings (we could repeat those words after Wat from Piecyk written in the fragment „GINDRY”: "from the side of palimpsest grey sheets of lice are moving”119).

118 A. Wat, O przetłumaczalności utworów poetyckich, [in:] idem, Ucieczka Lotha. Proza, edition K. Rutkowski, London 1988, p. 180.

119 A. Wat, JA z jednej strony i JA z drugiej strony mego mopsożelaznego piecyka, Warsaw 1920, p. 14. 
To confirm this principle it is possible to use traces of reading Piecyk left in footnotes worked out by subsequent editors of this text. Let us look at this fragment of text: „Gazowe światło wprzęgnę w spienione godziny i popędzę do zamku Sorja Morja"120 ["I will fire the gas lights in the frothy hours and rush to Sorja Morja's castle"]. Sorja Morja poses many problems to the editors. In Antologii polskiego futuryzmu i Nowej Sztuki these words are explained in the following way: "[...] fairytale castle in the Happy Islands, lying somewhere in the Red Sea"121. In turn, the authors of footnotes to another edition of Piecyk (from Anna Micińska and Jan Zieliński) write these words: "The name of the fairytale castle was created by the distortion of the name of the Khuriya Muriya archipelago in the Arabian Sea, where the Happy Islands were located" ${ }^{122}$. Władysław Panas in his excellent text ${ }^{123}$ exposing the kabbalistic roots of Piecyk also treats Sorja Morja castle as a near-undefined fantasy creation of Wat. The explanations are unclear because it is not known which fairy tales are involved. Indeed „zamek Sorja Morja” (in Norwegian Soria Moria slott [English Soria Moria Castle]) is a real textual entity and appears in Norwegian fairy tales with the same title (the fairy tales were written jointly by Jørgen Moe and Peter Christen Asbjørnsen $\left.{ }^{124}\right)$.

Let us also take another example. So a series of Latin names are interwoven into the texture of Piecyk: „Rosa Triplex”, „Sancta Lilias” (in Helena Zaworska and Zbigniew Jarosiński's edition it is maintained that the "form Lilias is Wat's idea” ${ }^{25}$ ), „Beata Beatrix” (associated in these editions with Dante's heroine Beatrice). To be honest, these Latin terms incorporated into the text seem to be suspended in a vacuum, rather pointless. However, if we add to them the following: „Monna Vanna”, then the reference becomes obvious and not accidental these four terms are the titles of four pictures by the English Pre-Raphaelite Dante Gabriel Rossetti. It is also worth mentioning here that the original

120 Ibidem, p. 15.

121 See footnote 99 to: A. Wat, JA z jednej strony i JA z drugiej strony mego mopsożelaznego piecyka, [in:] Antologia polskiego futuryzmu i Nowej Sztuki, introduction and commentary Z. Jarosiński, selection and preparation of texts H. Zaworska, Wrocław 1978, BN I, No. 230, p. 241. Further references to this work are given with the name APFiNS and the corresponding page numbers.

122 Footnote in A. Wat's edition Poezje, edition A. Micińska, J. Zieliński, postword J. Zieliński, Warsaw 1997, p. 465.

123 See W. Panas, „Antykwariat anielskich ekstrawagancji” albo „Swięty betkot”....

124 I used the following edition: Uwaga trolle! Baśnie norweskie, collected and notated P.Ch. Asbjørnsen, J. Moe, transl. M. Skoczko, Cracow 2010, pp. 86-101.

125 APFiNS, p. 257, footnote 80. 
character of the Beata Beatrix, a picture painted in the years 1864-1870 (Tate Gallery, London) inspired by Dante's Vita Nuova, was the artist's wife - Elizabeth Siddal, who died of laudanum overdose. In this way, the scattered text strands begin to connect and create a whole together (De Quincey and Baudelaire). Let us continue. In the fragment of Piecyk called Polowanie na bulwarach we read: "Słońce szarpane przez menady melancholijne «błękitne pończoszki»" ["The sun tugged by melancholic Maenads «blue stockings»"]. In the edition from the Antologia... in quotation marks, the fragment of the text read out is: "blue stockings (fr. bas bleu) - a humorous definition of literate or scholarly females. This is about emancipated women"126. In principle yes, but again this fragment is not devoid of actual text reference, a specific author and specific text worth pointing out. The French term bas bleu is derived from the English expression bluestockings and is an ironic term meaning a woman writer, a woman with intellectual pretensions, but also a bore. This term covers a whole range of cultural references, and I overlook the fact that the history of the term and associated customs dates back to 1400 when in Venice the della calza group was founded. At the end of the sixteenth century, this custom developed enormously among the French savants, and around 1780 also spread in England. Let us concentrate however on textual reference. Mentioned a bit further on in the same fragment of Piecyk Jules Amédée Barbey d'Aurevilly wrote a satire about such women Les bas-bleus, making fun of women writers (including George Sand). Barbey d'Aurevilly does not appear in Piecyk by accident, his name (also as the author of Les diaboliques) linked together with maenads and bas-bleus creates the next important thread in Piecyk, the satanic-erotic thread.

Allow us to reach for still another fragment. In Blaski piekiet we read: „Zwiędły rój skopców zachwyca się dymem papierosów” ["The withered swarm of skopcy delight in the smoke of cigarettes"]. In the edition from the Antologia... the expression „skopiec" is explained as a "castrated ram"127. Of course this is also something more, which links the text of the culture and has an important meaning for senses hidden in Piecyk. Skopcy or otherwise condemned (from Russian skopcy - 'castrati') is a sect that started in Russia in 1771 which declared that lust and sexual intercourse are sins. Skopcy considered castration as the only way to avoid sin. Is it possible to ignore such an important field of reflection here? Rather not, bearing in mind the strongly erotic, somatic plane of meaning included in this work.

126 Ibidem, p. 252.

127 Ibidem, p. 256. 
In the edition of Piecykfrom the Antologia..., there are also places which evidently require correction. This was partly undertaken by Micińska and Zieliński. And so for example in Blaski piekieł we read the expression "symparanekromenoi”"128 considered by Zaworska as "Wat's Greek neologism: together - next to each other - buried". Micińska and Zieliński indicated the source text, which can only be confirmed: „symparanekromenoi” ( $\Sigma \nu \mu \pi \alpha \rho a v \varepsilon \kappa \rho \omega \mu \varepsilon v o \iota)$ is a Greek expression created by Søren Kierkegaard. This means: 'the fellowship of buried lives' ${ }^{129}$.

However, after corrections by later editors there remained empty spaces, which it is worth filling in. And so at the end of the text, in the fragment Renesans these words appear: "False gossips vigorously gesticulating and whispering the Devil knows what above my head bloated with English disease". In Antologia the matter is explained thus: "English disease - rickets, a childhood disease, leading to bent and weakened bones" 130 . Basically yes, finally the head is swollen, deformed, so the association with the meaning of "English disease" seems reasonable. But no! What does rancidity have to do to with a swollen head? "English disease" is the name given to hypochondria, which appeared in the seventeenth century, or melancholy understood in the sense of excessive attention to oneself. This second meaning corresponds more to both the text and the whole of Piecyk. Melancholy is, in essence, explicitly (three times over) in Piecyk's text, and whether or not there is ironic connotation, it is important for the interpretation of the whole of the work, which is to constitute an expression of rebellion against culture and all the constraints imposed on it by people.

It can be clearly seen that the mere determination of correct meanings has caused many difficulties for the readers of Piecyk, and has ultimately led to a lack of understanding, misreading. Additionally, the text only appears to be vague, unreadable in places, and in fact, where semantics seem vague, it turns out there is a coherent whole deeply rooted in culture and also creates a coherent internal structure within the text.

A separate matter in Piecyk is the sound sphere - a real mine of diverse meanings, often based on anagrams, one of the most important formative elements

128 Ibidem, p. 257.

129 See S. Kierkegaard, Albo albo, transl. J. Iwaszkiewicz, vol. 1, Warsaw 1982, p. 155.

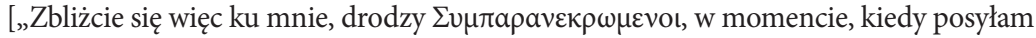
w świat moją tragiczną bohaterkę, kiedy obdarowuję córę żałoby posagiem cierpienia" (p. 173), "So come to me, dear $\Sigma v \mu \pi a \rho a v \varepsilon \kappa \rho \omega \mu \varepsilon v o l$, at the moment when I send my tragic heroine into the world, when I give my daughter a mournful dowry of suffering."]. See Either/Or. A Fragment of Life, transl. A. Hannay, Penguin Classics, London 1992.

130 APFiNS, p. 270. 
in this text is rhythm. Śniecikowska ${ }^{131}$ presents the widest analysis of sound in Piecyk in her essay, placing emphasis on polemical stylisation and showing the manner in which the Young Poland instrumentation, phonostylistics and poetic music are subjected to deformation, ridicule or parody in this work (this includes the destruction of the liquid, long phrase of symbolic poetry, the dissolution of words and also "primitivistic" echolalia, I would add to this also the parody of the Skamanders' texts, which from the perspective of form were firmly rooted in tradition). The analyses presented in this essay convince us about the "deconstructive" work undertaken by the poet in the sound sphere of Piecyk. This is one of the possible ways of reading and interpreting the sounds in this text. It is worthwhile, however, to look at the sounds of the poem also from the point of view of how they affect the rhythm of expression. From this point of view - contrary to Jakobson - speech sounds cannot always be described solely in terms of the function they perform in the language. Not everything can be reduced to function. It is impossible to move aside the subconscious and the body, which contributes to the sense contained in the texts. I would like to highlight these questions by analysing various spheres of meaning in Piecyk. In this text the body also has something very important to say.

In Ode III, in which world experience through skin is the most important theme, there are references to Piecyk: "when, stupid, I spoke of my consubstantial skin, to not renounce anything else like «tiu-tiu-tiu- tiam-tiam-tium»" - this is about an imprecise autoquotation from Ponure wędrówki („tim tiu tju tua tm tru tia tiam tiamtiom tium tiu tium tium", clearly in the text marked in a different font as if its sound was to be emphasised and separated from the whole statement), which is supposed to be onomatopoeia close to some unspecified sounds (the text of Piecyk suggests it is about squealing). This is to be the sequence of the unarticulated speech, which - as the poet himself later defines, indeed in cutting himself off from such practice - is supposed to be "consubstantial skin", and therefore identical with skin. There are more such places where the sounds are not articulated, for example in the fragment of Przepycha: „Palce, lce paapa $\mathrm{p}$ pa-pa", and also in the fragment Gnuśność, where we read: "I want to kiss trivial, cheeky girls and even nestle my head in blossoming fragile hips Trata ra ra ra" - placing together three words based on the triple repetition of the consonant groups containing the $r$ sounds goes into a meaningless sequence of sound. The whole sentence is saturated with eroticism and lust, and the subject's expression controls an uncontrollable drive that ultimately leads to meaninglessness.

131 B. Śniecikowska, „Nuż w uchu“?.., pp. 131-144. 
The sentence periods are long, extensive, clearly marked with paragraphs, and in them there are constant repetitions of parallelisms, counts and inversions that in this text constitute the constitutive synthesisers, which probably makes Piecyk's style to be regarded by some critics as "mannerist" or - as like Miłosz - as "secessionist". Such syntactic structure also gives the effect of "effusiveness", through this the subject's expression becomes too elongated, "dissipative".

Intratypography plays an important role in forming the rhythmic structure of the text (Stanisław Ignacy Witkiewicz paid attention to this fact in a slightly different way: "It should be emphasised as a positive value that Wat uses a variety of printing and character genres, that is in order to emphasise artistic values that can help for example in loud reading or declamation, and even in quiet comprehension"132):

- division of words or their combinations marked with divisors, sometimes incompatible with the division of a word into syllables („Pa-mię-tać”, „Ju tro o”, „udra-powania”); such notation imitates syllabic or clumsy, inept, deformed speech;

- majuscules at the beginning of words within individual sentences, whole phrases written in majuscules (for example „NAKŁADANO NA RĘCE RÓŻANE KAJDANKI”; "JA PIĘKNY JAK NIEBIESKIE PIĘKNO PĘKNIĘTEGO ANTYKU", the word "JA" is repeated many times in such notation throughout the text) - through which the meaning of these words is singled out and they become metacharacters;

- punctuation (for example exclamation marks within phrases, quotation marks, question marks indicating how to set the line of intonation during reading, which of course does not affect rhythm and sense).

The notation of the text on the pages is essential for reading it. That is why it is best to read Piecyk in the form in which it appeared in 1919, even with typographical errors or typographical inconsistencies (it is known from Wat's correspondence that the printer was responsible for these, but the poet himself accepted some of the innovations introduced by mistake).

On the lexical level, interesting phenomena that influence the rhythmic formulation of the expression are also noticeable. There are often random and illogical combinations of words, mechanical verbal combinations, slips of the tongue, spelling mistakes, awkwardness and verbal clumsiness, and grammatical, spelling and punctuation errors, which are not deliberate actions, deliberate

132 S.I. Witkiewicz, Aleksander Wat..., p. 409. 
violations of the rules that can often be found in futuristic texts (given that Wat corrected the mistakes after years, as I mentioned earlier, it follows that he was responsible for them and not the typesetter - however, this does not change the fact, to repeat once again, that the writer originally accepted the text in such a form; in addition, the phonetic transcription of words can also be found in Namopanik Charuna and in Namopanik barwistanu, Płodzenie, Żywoty). Here are a few examples: „rozzochrane” instead of „rozczochrane”, „podnoża” instead of „podnóża”, „dzwonic” instead of „dzwonnic”, „pułnoc” instead of „północ”, "pergamentów” instead of „pergaminów”, „paznogciem” (the word is repeated twice, but the correct form appears next to it three times "paznokcie"), "firnament" (repeated four times throughout the text) instead of "firmament", "trwoźne” instead of „trwożne”. There are many such places in the text. Where typographical or spelling errors occur, the context in which it appears is needed to read the correct meaning of the word. Of course, this does not remain without influence on the rhythm of the text - all these lopsided, distorted, deformed words, far from following any rules, punctuate the flow of speech, slow down reading, but above all blur the meaning, distort the sphere of semantic expression of poetic speech. Likewise, calques from French or Russian are inserted into the text. Wat has a particular tendency to polish-ise foreign words: „konurze”, "maniquirować”, „szagren”, „timbrach”, biwuak”, „caloriferze”, where the words often retain the characteristics of the original notation. This is not an intrusive poetic mannerism. These words appear in the text as if unconsciously prompted the writing is as if it is in French but the sound is Polish. The phonetics of the French interjection implies the use of a Polish word with a similar sound structure: „maniquirować markotnym”.

At the syntactic level, the division of long, extended syntax periods into smaller units is marked with punctuation and has a critical significance for intonation, intensifying in many parts of the work progressively, so that it is possible to isolate those parts that are subject to particular pressure. Intonation through the whole text of Piecyk is highly varied and subjected to a variety of emotional modulations.

In the prosodic layer, and mainly by the position of the phones, repeatedly overlaid sentences are laid out in "chains" (concatenation). Within them, whole words, groups or parts of words are repeated, as well as individual phones. All these elements play a dominant role in shaping the rhythm (based on, amongst others, the phonic and intonation networks) of Piecyk. It is worth looking a little more closely at the mentioned systems, as it is possible to identify some regularities (not just regular repetition of specific elements, as a construction principle, which is just concatenation). In most cases, the arrangement of sounds, words or 
elements is such that they are set in series, one element joins the other in sound, they correspond according to the principle of echo, reflection (almost mirror), as is the case for example in the passage GINDRY:

GINDRY. Różańcowe Nizze i nic[.] Z strun: jaspisowe struny - i nic. Słysz, Gindry, słysz! gdy śnią buruny strun - idę witać kręgosłup mojej Gindry. Gdy śnią buruny strun! gdy śnią buruny!

The secret word "Gindry"133 finds its development by repeating the whole word several times, but also through phonetic means, as subsequent words use repetitions of the same sounds that create them. The Italian word "Nizza” (Nice) in sound is connected to the Polish word "nic”, and going on, „sturny” is linked to the word „buruny” (foamed waves, combers). In the fragment called Męzkość we read the sentence: „Czeka na twe przyjście, by sercem poigrać jak sersem” the Polish word "serce" is anagramatically linked to the French word cerceau (meaning a known game), written in a polish-ised version as „serso". In another place, in the third part of GINDRY, the word "pląs" is repeated twice, is transversely connected, also on the principle of anagram, with French balançons ('we swing' - like dancing). Words from Polish and French are linked as signifiant, but their juxtaposition on this principle builds signifiance of expression. In the fragment Niemoc we read a sentence in which we can see a similar practice: „Blogosławieństwo na buruny na opale na hałaśliwe gwiazd runy na heljotropy..." - in anagramatic writing runes (as an alphabet) become connected to buruny. This is not a simple effect of euphony, co-sounding, which would be supposed to constitute an aesthetic element of expression. Another good example is the repeated repetition of the phones that make up the word „wieki” within the space of three contiguous sentences in the fragment of Autoportret: „Sztylet bez powieki. Wieki bez powieki. Powieki bez powieki. Kto powie czy, jako pawie, wie co wypowie" - an effect of paronomasia?, not completely, because on the basis of this phonetic repetition a whole series of linearly and transversely linked words arises (in the preceding sentences the word "powieki” also appears several times). In turn in the fragment titled Warjat, written indeed in capital letters: WARJAT, already in the title itself we can read the words „WAT" and "JA" [“I, $m e$ "] - the latter is clearly highlighted in the fourth sentence of this passage: JA. A French phrase appears after the title word, Je suis fou - "I am a madman" or quite simply "I am crazy". Here we have contact with an anagram similar to that

133 Tomas Venclova considers this mysterious name as an anagram of the word ,androgyne". I refer in this regard to the analysis contained in his monograph Aleksander Wat..., p. 107. 
which is in the verse Policjant from 1924, in which God is compared to a policeman guarding the world - as the anagram shows, God is a bulldog: „policjant o oku buldoga" ["Policeman with the eye of a bulldog"]. Something similar is done in the poem Żywoty ["Lives"], which is worth quoting in full:

I kosujka na białopiętrzach sfrunęła i płonącoręką dobiedrza, złotogórzy i podgórza i rozgór tu grały namopaniki.

Po nikach czarnoważe ważki i grajce i rozgarniać krawędzi żółciebiesów i rozwrażon i tragowąszcz i trawągoszcz gąszcze zielone, zielone, zielone! na tramwajach tram na wyjach trawa! i kosujka płonąc tak i płomyki płomień rozpłonecznionych bezpłonięć dopłonąć, dopłonąć płonacze i płonaczki spłonący płomieńczarze białouście! daj białouściech! Gdzie kosujka płonęła płomieniem płonących płoń?

O! gdzie?

i ty karcze, karczyno róż znuż rzęs

i ty karczem do karczem pędzące niebo

i nieba przyszły siwe nagłe banie nieba

i kosujka płacze płaczem płaczących szczęk.

[Translator's note - this poem is mostly a play on words, or indeed language, and cannot really be translated.]

In formal terms this is the work most closely related to Namopanik Charuna and Namopanika Barwistanu. The name - if so to say - the genre appears finally in the text itself. Namopaniki finally gained a separate entry in Słownik rodzajów i gatunków literackich. Namopanik - is a strange genre that appears in the common history of literature in two of Wat's texts: Namopanik charuna and Namopańik Barwistanu. They have been interpreted and discussed many times, and the most interesting works have come from the pens of Tomas Venclova ${ }^{134}$ and Jarosław Płuciennik ${ }^{135}$; Beata Śniecikowska also proposes her own, original and interesting interpretation ${ }^{136}$. Interpreters pay close attention to the relationship with James Joyce, Velimir Khlebnikov and Julian Tuwim, pointing to the religious contexts of the genre. Reading Wat, I have repeatedly pointed out that from the point of view of form, the namopanik is reminiscent of prayer - an

134 Ibidem, pp. 70-72.

135 J. Płuciennik, [entry:] Namopanik, [in:] Słownik rodzajów i gatunków literackich, ed. G. Gazda, S. Tynecka-Makowska, Cracow 2006, pp. 440-442.

136 B. Śniecikowska, „Nuż w uchu“?..., pp. 171-205. 
important comment also noted by Śniecikowska. Indeed, both texts are made on the basis of prayer and both must be read with great sensitivity to phonetics. Tomas Venclova read them in relation to Ferdinand de Saussure's anagrams (to be precise, something to which Venclova does not pay attention, this is about the paragram, upon which de Saussure relied for the absorption of many meanings in a poetic message that can be centralised by some sense). Śniecikowska draws attention to de Saussure's anagrams, but does not use his ideas for her analyses, which follow a different methodology and according to another theory of text, different from that which was formed in France in close connection with Saussure's theories. Jarosław Płuciennik also wrote about the major role of phonetic systems. Śniecikowska recognises the name "namopanik” as “made by Wat himself, probably - with use of the anagram method - from "manii» and "paniki»" (I am following A. Pomorski's suggestion here $)^{137}$. I think contrary to the view that such an interpretation does not confirm the fact of placing the words "namo! Panik" on the cover of Nieśmiertelny tom futuryz. None of the above mentioned insightful readers of Wat has paid any attention to the fact that the formula contained in the genretitle formulae is a word formed on the principle of anagram (in de Saussure's understanding, phonetically, not stylistically) from prayer or litany words "Nam o Panie” - the poet changes only the repartition of the words which in a phonetic sequence give "namopanik”. Let us leave namopaniki and go back to Żywoty ["Lives"]. What are the title lives? Is it a reference to the lives of the saints? Not at all. If lives, then rather the "lives of words", which in this text begin to live a completely separate life. In the sphere of sounds there is no graspable system, the meaning is almost completely blurry, one could even say that the principle of this text is rather breaking and scattering meanings. It's almost like a pure signifiant feast, indeed, few words can be fully understood, and most meanings can only be guessed, which is linked to the peculiar pleasure of reading leaving uncertainty or even suspended in uncertainty. Everything starts with the word "kosujka" that appears in the first line (in the whole text it appears two more times), and it is not quite clear how to read this contamination. Helena Zaworska suggested that this is a bird similar to a blackbird ["kos"] and jay ["sojka"] ${ }^{138}$, but it could also equally be a name based on the words "sójka” and "kosówka”. The entire work is based on anagrammatic writing, and in it phonetic systems create whole concatenation strings, further emphasised by polisyndeton, for example „czarnoważe ważki i grajce i rozgarniać”, „i

137 Ibidem, p. 171.

138 H. Zaworkka, Nurt „Nowej Sztuki”, [in:] Literatura polska 1918-1975, ed. A. Brodzka, H. Zaworska, S. Żółkiewski, vol. 1, Warsaw 1975, p. 370. 
rozwrażon i tragowąszcz”, „karcze” (as trunks) are placed with „karczyno” and with „karczem” (variants of the word „karcz”) and „karczem” (from „karczma”), group „pło" (from the words „płomien" and „płonąć") is here repeated 18 times, the word „tram” overlaps into the word „tramwaj” („tram”, which also appears later in the poem by Jerzy Jankowski Tram wpopszek ulicy. Skruty prozy i poemy from 1920), „wyjach" (most probably means "łąkach”, the same word appears in Piecyk in the fragment D'infinite: „Na żółtych wyjach parskać”), just like „trawa” has its reflection in "tramwajach”, "tragowąszcz" is reflected entirely by an anagram in "trawągoszcz”. To these linear relationships we also add transversal: the group "tra” is repeated six times in text scattered throughout the text, referred to in the third line from the end, "niebo" is repeated two more times and absorbed into the split-form anagram "banie nieba”, to this there is added the relations of the group "tra" - pure signifiance, pleasure of articulation, pleasure of experiencing rhythm, a bodily gesture contained in a poetic word. It is not absurd, no game or word play, no imitation of Velimir Khlebnikov's techniques, nor any vocal instrumentation in poetic speech. As mentioned by Jeleński, the author of Ciemne świecidło discovered the unconsciousness of the body at an early stage of his work. In namopanika, in Żywoty and in many places in Piecyk itself, the text ceases to be a message, rather an attempt to expose a poetic language that penetrates the meaning of words, gives way to the bodily rhythm strongly emphasised in the poetic text itself. The place of language is to be found in the body, in the end it decides the way of shaping the articulation organs, and so the form of sounds, tension of accent and intonation, in short, the rhythm of speech.

Let us return once more to Piecyk. Now, the rhythmic process of speech in this work is based on a network of phonetic and semantic repetitions (the words interlock, overlap with each other), which means that in the text a transversal arrangement of "connected vessels", based on the repeated repetition of the same vowels, comes in to being.

Anagrams do not appear so frequently just in Piecyk, but also in other futuristic texts - they could be described as somatic shifters, and so as elements of poetic expression that combine the body and the word that arise from the rhythmic impulse that emanates directly from the act of writing into the body. In Wat's somatic writing there is something visceral, and I think John Vernon's thinking is very close to it, who in Poetry and Body identifies the poetic work directly with the physical process, and even - as it says - "visceral", and also states that the words have their "visceral energy", which fills their own space of desire ${ }^{139}$. If one agrees that this visceral energy actually exists in words, it emanates directly from the body and becomes tangible through 
rhythm. The real body is certainly present in literary texts, and its presence, its specific resonance is possible thanks to rhythm, which for every poet, and even every single work is unique and unrepeatable. This is not just a matter of aesthetics and sound functions, but of rhythmic coercion. The phonetic system of expression goes hand in hand with the lexis, the same phenomenon occurs at the lexical level, where the words are often set in far-distance pairs. This rule which we can find in Piecyk, corresponds to de Saussure's "law of linking in pairs". An array of phones and phone groups return very often according to the rules of anagrams in the form of extended echoes. Repeated phonetic and lexical recurrences occur in pairs or in longer series. Poeticness is based in this case not so much on repetition of something, but on the clearing of unequivocal meanings. The experience of pleasure derived from reading is based on constant delay, postponement. Rhythm causes continuous phonetic, lexi$\mathrm{cal}$ and syntactic recurrences to form a moving assemblage from the text which thus gains its polyphonic character. 



\section{Somatic style - Eugeniusz Tkaczyszyn-Dycki}

\section{Somatic style}

Somatic style is an invention of Richard Shusterman ${ }^{140}$ and will form the basis of this reflection (although I would prefer to say meditation) on the poetry of Eugeniusz Tkaczyszyn-Dycki. The "somatic style" is a term - it must be admitted which is indeed impressive and extremely meaningful, and since it exists, there is nothing to prevent it from defining Dycki's style. Shusterman uses it in a very specific way, and for the purposes of this argument it is necessary to modify this definition, departing - albeit not completely - from the context of the researcher's somatoaesthetics. Speaking of style, Shusterman reaches back to the Latin roots of the word ${ }^{141}$, to its etymology and so to stylus, which in ancient Rome meant a sharpened object for drawing and writing on wooden tablets covered with wax. Over time the scope of the word has been shifted to oral and written speech (style of speaking, style of writing), and style itself has become an aesthetic quality. In a variety of linguistic or literary criticism definitions of style, most commonly the manner of creating expression is based on making choices, interpreting and construing - as Janusz Sławiński says - the "language material"142. In dictionaries and textbooks there are artistic styles, epoch styles, author's styles, flowery style, rhetorical style, macaronic style, scientific style or journalism, there are lofty styles, low styles, straight styles, medium styles. There is no unique style, and I would like to talk about the style of

140 R. Shusterman, Somatic Style, "The Journal of Aesthetics and Art Criticism” Spring 2011, No. 2(69), pp. 147-159. Shusterman's idea of somatic style is not merely an external image of a human character but an integral expression (or aspect) of character, because the character itself is expressed by the behaviour and the somatic attitude. Shusterman divides somatic styles into general ones (generic), may be, for example different types of dress code: formal, semi-formal, business informal, smart casual, business casual, they may also be different ethnic styles, for example Scottish, Hassidic, Japanese, etc., or taste-group styles: hip-hop, corporate, preppie and personal; individual styles can exist within the range of general styles. Recognition of somatic style is guaranteed by five senses: first sight and then hearing (distance perception, the question of a unique voice) and further on smell, taste and touch, and next to them also proprioception, so deep feeling, kinaesthetic sense - this is mainly about the way the body interacts with the environment.

141 Ibidem, p. 147.

142 J. Sławiński, [entry:] Styl, [in:] M. Głowiński, T. Kostkiewiczowa, J. Sławiński, A. Okopień-Sławińska, Słownik terminów literackich, Wrocław 1998, p. 532. 
the author of Peregrynarz. In most definitions, systematicity and repetition of characteristics are most important. Generally there is no discussion of non-repetitiveness (even the style of the author, so individual style is defined with respect to the "language system"143, that is it must be different from some pattern, deviate from what constitutes the norm, some certain point of reference) or that the shape of the style is influenced by elements emerging from the unconscious. The etymology of the word "style" unambiguously indicates somaticism, on the one hand it is about orality and the voice, on the other the bodily gesture of writing, inscription - by its nature style is somatic, and every style, as Shusterman states, is in a certain way somatic ${ }^{144}$. It should be added, however, that none of the somatic styles are ever the same, each is unique, exceptional and unrepeatable. This is how I would like to see Dycki's style, because when reading his poems we are dealing with a unique event (the event of singularity), about which Jacques Derrida says much in his works (particularly Shibboleth for Paul Celan), and later also Derek Attridge ${ }^{145}$.

I consider the term "somatic style", to give Dycki's style a name, a style that without body cannot be worked around. I am not just thinking about thematic concepts or motifs ${ }^{146}$, the body - as a theme - is ubiquitous, plural and polymorphic in Dycki (looking at the collection of texts, it would be possible to catalogue an entire gallery of bodies, young and old bodies, mad bodies and those infested or diseased, boy's and girl's bodies, men's and women's bodies). I do not mean the exchange between the body and the sign. I do not want to use the word exchange, which is inevitably associated with economics. I mean rather the equivalence between the body and the sign, which in this case emerges from the text in an open and clear manner, which cannot in any way be ignored. Eugeniusz Tkaczyszyn-Dycki, through and through, is a somatic poet. In this poetry the body is the main axis of thought transformed into rhizomatically ordered words.

\section{Body and entity}

The body is a figure of the subject, but this one can never be seen as a single point in Dycki's poetry. The subject in Dycki's poetry is not a single point, but multiplied, multidimensional. There is no single "me", there are many "me", and

143 T. Kostkiewiczowa, [entry:] Styl autora, [in:] Słownik terminów literackich..., p. 533.

144 R. Shusterman, Somatic Style..., p. 147.

145 D. Attridge, The Singularity of Literature, London 2004, pp. 63-72.

146 Compare M. Jurzysta, „Moja fizjologia // coś co jest święte...” Cielesność w poezji Eugeniusza Tkaczyszyna-Dyckiego, [in:] Cielesność w polskiej poezji najnowszej, ed. T. Cieślak, K. Pietrych, Łódź 2010, pp. 207-222. 
more, it is difficult to talk about the homogeneity of the subject while others are in me, and this formula confirms the specific polyphony of Dycki's poetry (polyphonic in the sense that it constantly and in many ways speaks with other people's voices). Dycki's bodies are many, from the very beginning, from the first line of the volume Nenia $i$ inne wiersze (1990), the same poem opens a large collection Oddam wiersze $w$ dobre ręce from 2010: „wszystkie moje ciała / których jest co niemiara..."147, right until the last volume Imię $i$ znamię (2011), in which the equivalence of the body and the words are emphasised by the title itself. The title of this volume points to the act of writing, closely related to the body. It is possible here to return to the Latin word stylus and to the technique of writing on wax or clay, whose warmth and softness affect the writing body and force the gentleness and mildness of their movements. When the wax or clay dries out, it creates a kind of cut, scar or mark that clash in meaning, the process of cooling or drying, like skin on the body, covers them, protecting them from damage and modification ${ }^{148}$. This is a mark that remains on the body of the text, like on the human body - an indelible, unchangeable trace with which there is always a history. This is a trace on the body and a trace in memory (the history of my body), and the map of the body covered with scars or marks is a map of the individual memory, from which the one and only, unique history of a single existence (wounds, scars, cuts) can be read.

Dycki of course has many bodies, but apart from these there are other bodies and voices (mothers, family members, friends, neighbours, randomly met people). It is these bodies and voices that in a specific way trigger history. Dycki's somatic style is based on incredible kinaesthesia, which should be understood here as the ability to perceive and define the place of one's own body and the bodies of other people.

What is the place of the body in this poetry, where is the body actually located, does it have its place at all, or is it anchored somewhere? Rather not, of which we are convinced by the words of Piosenki o wolności (OWDR, p. 181):

jesień już Panie a moje ciało jest

w podróży odkąd wykradłem się z domu

mojej matki i wybrałem wolność

moje ciało jest w ciągłej podróży

147 E. Tkaczyszyn-Dycki, Oddam wiersze w dobre ręce (1988-2010), Wrocław 2010, p. 9. All the quotes from the poems have been sourced from this edition and are indicated with the designation OWDR and the number of the relevant page.

148 I found many inspiring remarks concerning this matter in: S. Connor, The Book of Skin, London 2004, p. 83. 
podoba się innym wymyka się władzy

którą nad nim sprawuję kiedy znowu

wracam do komisariatu choć powiadają

że nie trzyma się kupy od paru lat

moje ciało jest w ciągłej podróży wymyka się

najprędzej tym którzy mnie uszczuplają i biorą

za kpa: nie po to Panie wykradłem się

$\mathrm{z}$ domu mojej matki by pójść do ciociobaru

["it's already autumn my Lord and my body / has been on a journey since I had escaped the house / of my mother and chose freedom / my body is on a constant journey // it is admired by others and gets out of my control / when I get back / to the police station although they say / that it has not been in good shape / for a couple of years // my body is on a constant journey it gets away from those / who deplete me and treat me as a fool / the quickest: I did not escape the house / of my mother, o Lord, to end up in a gay bar"]

The body does not have its permanent place of existence here, freedom is without freedom, inevitable escape towards a form of closure, exclusion („ciociobar”). One of the most important phrases, indeed taken from Herbsttag (Dnia jesiennego) by Rainer Maria Rilke ${ }^{149}$, of the entire set of Dycki poems, finally speaks by insistently repeating the words: „Jesien już Panie a ja nie mam domu” ${ }^{150}$; the

\section{Herbsttag}

Herr, es ist Zeit. Der Sommer war sehr groß.

Leg deinen Schatten auf die Sonnenuhren, und auf den Fluren lass die Winde los.

Befiehl den letzten Früchten, voll zu sein; gib ihnen noch zwei südlichere Tage, dränge sie zur Vollendung hin, und jage die letzte Süße in den schweren Wein.

Wer jetzt kein Haus hat, baut sich keines mehr.

Wer jetzt allein ist, wird es lange bleiben, wird wachen, lesen, lange Briefe schreiben und wird in den Alleen hin und her unruhig wandern, wenn die Blätter treiben.

Rainer Maria Rilke, 21.9.1902, Paris

150 It should be noted in the margin that the reading of these words by Cezary Zalewski is rather unjustified. According to Zalewski: “The phrase „Panie” („Jesień już Panie...”) which appears in the incipits of some of the texts: this derives from colloquial language, where is the sign of the intimate relationship between the interlocutors" (C. Zalewski, Dworce, dworce jak łożyska wielkich rzek (podróże i przystanki Eugeniusza TkaczyszynaDyckiego, [in:] Eugeniusz Tkaczyszyn-Dycki i krytycy, ed. G. Jankowicz, Cracow 2001, 
collection of poems from 2000 is called Przewodnik dla bezdomnych niezależnie od miejsca zamieszkania, and in poem XXXVI from the volume Nenia $i$ inne wiersze (OWDR, p. 45) we read:

znowu przyjechałem w przemyskie

pełne bogów polskich i ukraińskich

rodzina kurczy się coraz bardziej

a ja rozrastam w samotności

jestem jak poganin który nie ma

domu pośród swoich zmarłych

dzień rozpoczynam od krzyku

nieodrodny syn tych co poumierali

["I came to przemyskie again / full of Polish and Ukrainian gods / my family shrinks more and more / and I proliferate in loneliness // I am like a heathen with no / home among his dead / my days begin with my cry / true son of those who are gone"]

In turn, in the poem CCXVI from the volume Daleko stad zostawitem swoje dawne i niedawne ciało (2003) we read these words:

jesień już Panie daleko stąd

zostawilem swoje dawne i niedawne

ciało jakie jeszcze oglądam

kiedy otwieram jedną furtkę po drugiej...

["Autumn already my Lord far away / I left my old and recent /body which I can still see / as I open one gate after another"]

(OWDR, p. 249)

Examples could easily be multiplied. This position of a man without space (poet) is related both to history (on a micro and macro scale) and to Dycki's genealogy (this is about his Ukrainian roots, his unclear and complex status of national and linguistic affiliation), with the ambiguity of erotic experiences: homo- and heterosexual, with the experience of modern $\operatorname{man}^{151}$, who cannot and does not

p. 66). The phrase evidently does not come from colloquial language, but it is an obvious address to the Highest, which is confirmed by the spelling of that word in capital letters. These are - as I think - the words of the started and never-ended prayer. Taken from colloquial language "Panie" is not, as Zalewski claims, a phrase that emphasises intimacy but alienation, resentment, hostility and aggression, as, for example in the famous Wały Jagiellonskie song: "Panie, wzbronione tu bieganie".

151 Here, I would like to understand modernity in the same way as Henri Meschonnic: here we need not just the dictionary definition or the encyclopaedic definition of 
want (but also does not need) to unequivocally define his position in the world of everyday life. Through his poetry Dycki appears to be the greatest atopic ${ }^{152}$ of modernity, and even surmodernity (surmodernité - Marc Augés term).

\section{Body and word}

Many of Dycki's texts have a strongly exposed metatextual plane. Metaliterary reflection, autothematicism and autotelicism, analysis of the act of writing, reflections on the possibilities and limits of linguistic representation, in brief - strongly

"modernity", but rather one that takes into account the speaker. Henri Meschonnic defines modernity as the work of the subject (H. Meschonnic, Modernité, modernité, Paris 2000, pp. 33-34). In such a view, "modernity" is a term devoid of a permanent, objective reference and has only one subject. Modernity itself becomes the signifiant of a subject, understood not just linguistically (not an "acoustic picture", as in de Saussure), but also in poetry, where it becomes a distributor of signifiance, and this goes beyond the sign and the lexical meaning of words, in consequence of association with other words. Putting it differently, this is about not only analysing the meaning of the word "modernity", but rather the way of speaking about modernity in scientific, essay or literary texts, and each time this is unrepeatable and unique.

152 This old Greek word "atopia" (átómía) perfectly reflects the condition of the modern man, to which Dycki gives testimony, but also many other modern writers, means "absurdity", "singularity", "unusualness" and "strangeness" and "sin" (Słownik grecko-polski, based on the dictionary by Z. Węclewski, ed. O. Jurewicz, vol. 1, Warsaw 2000, p. 125). Among other meanings are not only synonymous terms, but also those that somewhat extend the semantic field of the word: "weirdness", "absurdity", "wickedness", "villainy" or "crime" (H.G. Liddell, R. Scott, A Greek-English Lexicon, Oxford 1996, p. 272). Semantics considerably widen átó strangely, paradoxically, oddly, unnaturally, disgustingly, abominably, wickedly, vilely, sinfully, not spatially', and as an adjective: 'absurd, improper' (Słownik grecko-polski..., p. 125). This multiple meaning word appears often in the texts of Plutarch (Parallel Lives), and also Plato who described Socrates using exactly the word átó tral problem in experiencing atopy become isolation and alienation. By observing the present, I am setting myself apart, distancing myself from a reality that is unfavourable and unfriendly to me (words do not have ethical weight for me). This reality is too often built on the basis of circular opinions (the specificity of bourgeois, petty bourgeois culture, but also the specificity of mass culture in which doxa becomes a decidedly dominant element). Atopia is a non-place, is close to Derridian différance, because it falls between the poles of unequivocal, categorical positions. The experience of atopia is also emerging from the observation of everyday life, which is often absurd and clumsy, full of simulacra, and flooded with substitution, it loses its transparency, clarity and brightness, and worse sometimes arouses distaste and even disgust. 
accented awareness of the creative act and the awareness of the word are ubiquitous here. It is worth giving here even just a few examples:

na Boga kto wymyślił tę rzeczywistość

bo nie ja który grzebię się w wierszykach

nazywają to procesem tworzenia

niech nazywają jak chcą nic im do mojego procesu

gnicia proszę wycieczki nic im do Dycia

(CCXXXVII, OWDR, p. 272)

["Good heavens who came up with this reality / definitely not me fiddling with rhymes / the creative process they call it / let them say whatever they want, my deteriorative process is none of their business / chaps, none of their business is Dycio"]

z trudem używam języka (jestem

poetą współczesnym)...

(CCXXXIX Powołanie, OWDR, p. 274)

[“with difficulty I use language (I am / a modern poet)...."]

piszę coraz ciemniejsze wiersze gdy jest

dzień i zasiadam do papieru odrzucając

pustosłowie natchnienie natchnienia nie ma panie

i panowie papier to jest pozostałość z nocy

(CCXLIX Szmugler, OWDR, p. 284)

["I write darker and darker poems during the / day and I sit over the paper rejecting / chanting-talk inspiration there is no inspiration ladies /and gentlemen the paper is a remnant of the night"]

istotą poezji jest nie tyle zasadność

co bezzasadność napomknień i powtórzeń

(CCCXXXI, OWDR, p. 371)

["the essence of poetry lies not so much in the validity / but rather the invalidity of allusions and repetitions"]

...współczesna poezja polska to nekrologi

(CCCXXXVII, OWDR, p. 377)

[“...current Polish poetry consists of obituaries"]

...kto zaś potrzebuje natchnienia

musi się obracać nie tylko pośród

kamieni ale i nieczytelnych inskrypcji

(CCCLXXIII, OWDR, p. 415) 
[“...whoever needs inspiration/ / has to travel not only in the circles of / stones but also illegible inscriptions"]

...przypomnijmy że w zakres

dobrej poezji wchodzą nie tyle cmentarne

i pocerkiewne kamienie co kamienie

w ogóle i od lat nieczytelne inskrypcje

(CCCLXXIV, OWDR, p. 416)

[“...let's remember that good poetry / contains not so much gravestones / and orthodox headstones but stones / per se and inscriptions illegible for years"]

...od lat bowiem widzę

nadaremność poezji kiedy usiłuję sobie

przypomnieć coś więcej aniżeli jabłuszka

i hniłki... ${ }^{153}$

[“... for many years now I have understood / that poetry is in vain when I am trying to / remember something more than apples / and rotten fruit”]

...z szaleństwa rzucę się

przed siebie w ogień jeszcze większej

choroby: niech to będzie poezja

["...in my madness I will throw myself / forward into the fire of an even greater / illness: let it be poetry"]

poezja bowiem domaga się (niczym modlitwa

za zmarłych) wciąż nowych imion

["poetry requires (like a prayer / for the dead) new names again and again"]

poeta bowiem zrobi wiersz z każdego

ździebka choćby z nekrologu

["because a poet can create a poem from the tiniest / speck even from an obituary"]

To this collection of quotations we should certainly add the remarkable poem Ars poetica:

153 E. Tkaczyszyn-Dycki, Imię i znamię, Wrocław 2011, p. 6. Further references to this volume with the designation IZ and the number of the relevant page. 
chciałem pisać wiersze o koniokradach

i lachociągach złodziejach i spermojadach

chciałem uwzględnić wszystkich świrów

$\mathrm{z}$ matką w roli głównej i wszystkich bohaterów

nie chciałem stronić w poezji od darmozjadów

wyrzutków podrzutków i kościelnych dziadów

wyłącznie i rozłącznie ze mną w przypływie natchnienia

popełniłem wszak „Piosenkę utracjusza” ale przyszła

niemożność niepłodność i skończyłem na Leszku

(CCCLXXV Ars poetica, OWDR, p. 417)

["I wanted to write poems about rustlers / and cocksuckers thieves and cum drinkers / I wanted to include all freaks / with mother playing the first fiddle and all heroes // I didn't want to omit spongers / drop-outs foundlings and church beggars / in my poetry including and excluding me after all / at the surge of inspiration I conceived The Song of a Profligate but / the inability infertility overpowered me and I finished with Leszek"]

This collection of quotations makes it possible to generalise the determinants of Dycki's poetry. Thankfully, it is impossible to speak of immanent poetics, and anyhow there is no need for this, for it is unpredictable poetry, surprising, poetry that cannot be contained in some general formulae taken from poetics.

One of the first things that catches the eye when reading Dycki's texts is the Roman numbering of individual texts that make up the unbreakable whole. This is about continuity and wholeness, textual continuity and the wholeness as a corpus (wholeness of the work and/or body). The collection of these texts cannot be read randomly (Jarosław Mikołajewski rightly pointed to the fact that subsequent collections of Dycki's poems are "still the same book"154), they should be read in their entirety and then they gain a very important and astonishing characteristic of romanesque - storytelling. Subsequent poems introduce and develop new threads, but also return to those previously written by persistent repetition of certain phrases. Here, we are dealing with a specific mise-en-abyme. Dycki's writing takes shape in endless narration. A single work can be read but not fully interpreted. Interpretability and readability of these lines is possible only if they are treated as a whole (the numbering of the lines precisely confirms this).

Dycki is an archaeologist of words. This is not just about reaching back to archaism, absolutely not. It is rather that the poet has a remarkable awareness of words, which takes into account their biology and history (they are in these lines like living creatures, which also have their own history). The words of this

154 J. Mikołajewski, Historia odrębna, [in:] Eugeniusz Tkaczyszyn-Dycki i krytycy..., p. 5. 
poetry come from many different registers: colloquial, old-fashioned, vulgarisms, Ukrainianisms, which indeed have special significance. These words, like everything in this poetry (constellations of people and things, of the world of nature and culture), are mutilated, incomplete, go together with great difficulty, and are joined only by thin strands of texts.

If we talk about archaeology of words, it is worth using even an example such as „cieleśnik” (poem CXXVI from the volume Liber mortuorum, OWDR, p. 153). This word is actually unreadable, it only apparently looks like a neologism. It is necessary to reach back to its long-ago meaning to understand it. In Karłowicz's dictionary it is a "lustful person", for Linde "a carnal person, devoted to the body", "unrestrained people" or putting it differently "lustful". This word carries the weight of signifying erotica - one of the most important themes of Dycki's lyricism, regardless of whether it is auto-, homo- or heterosexual, it does not matter whether it is innocent boy's play or youthful sexual excesses. This theme is crucial for understanding the poet's perception of the world and for reception of his poetry: body - erotica - semantics. Words in this poetry are subjected to loving caresses. There is no experience and no meaning without the eroticism which is omnipresent here. Erotic experience as a bodily experience is one of the keys to understanding how words are given meaning in Dyckis texts. On the other hand, reading this poetry is closely connected with the experience of the enjoyment of the text, of which Roland Barthes wrote, and yet this is clearly linked to eroticism.

The poet's last volume titled Imie $i$ znamie tells much about relationships between the body and the word. The title of the volume itself defines the relationship of coexistence. Word and body melt into an unbreakable whole, and their entanglement also says much about writing itself. How many names are forever fixed in words in this poetry. Names, place names, and whole series of words from the Podlachian dialect, words that are like shibboleths making possible access to the poetic word, opening history on a macro and micro scale. This great history is constantly returning through interruptions in many different poems and commentary on the poems in the volume Imię i znamie („rezun” - member of the Ukrainian Insurgent Army [UPA], myrmidon, murderer, mother of a "bandit", polonised father of a nationalist), but its image is not unequivocal, it has nothing to do with what was left behind from the ideology of the Polish People's Republic (PRL). This image forces thought, reflection, and demands verification of circular opinions, draws attention to the complexity of history itself and the tragedy of individual fate, the tragic nature of people who have been lost in history, or are completely deprived of their identity. „Hniłki” ["rotten fruit”] ('gruszki ulęgałki' [“wild pears”]), „czerecha” ('wiśnia’ [“cherries”]), „bziuczki” ('czereśnie’ [“sour cherries”]), 
„pastywnyk” ('pastwisko' [“pasture”]), „kiłakiczka” ('jaśmin’ [“jasmine”]), „nasermater" ('byle jak, źle, niedbale' ["so, bad, careless"]; in Dycki's poetry these are characterised by vulgarism: „choć to ojciec mówił wyjątkowo po chachłacku / «karagula» i wyjątkowo nieładnie "nasermater»" ["although it was father who exceptionally spoke vagrancy/«karagula» and exceptionally unpleasant «nasermater»"]) - all of these words need to be written into the poem, repeated many times, not for the pleasure of listening to them, but to perform an archaeological exploration of their meaning, which helps us to find and reveal that everyday life of yore. Without discovery of this everyday life, which includes the field of microhistory, individual and single history (me myself, my family, my closest relatives), it is impossible to reconstruct identity. Apart from the unusual sound, each of these words has its own biology and history - it is a name, a first name and at the same time a stigma stamped onto the body.

Haloperidol is the title of a poem from the volume Przewodnik dla bezdomnych. This is the name of a neuroleptic drug used to treat schizophrenia. This illness constantly returns as a theme in many poems - on the one hand, in the dramatic and shocking poems describing the suffering mother or suffering friend, on the other hand, as part of the individual experience, the acute anxiety of this illness: „schizofrenia jest domem / bożym odkąd zachorowałem...” [„schizophrenia is home / since from when I became ill..."] (LII, OWDR, p. 65). Haloperidol at the end of the line becomes "halopopierdolem" and returns in the same form in the next line along with „valium”. This is apparently a simple pun, but created through an anagram it has a deep meaning. This is not about causing laughter, the simple naming of the drug with vulgarism, but the sense of the word produced by the body experiencing disease in many different ways, a disease that is so exceptionally sketched in this verse:

schizofrenia to ten czarnopióry ptak

z wczoraj i ten czarnopióry ptak z dzisiaj

gnieżdżący się przede wszystkim w teraz

w tym samym co zawsze ubóstwie pierza

nikt zaprawdę nikt nas wystawionych

do wiatru nie obsypał puchem tajemnicą

i nikt nas nie zawrócił $z$ drogi

gdy porzuciliśmy orientację jako siebie

nie potrzebowaliśmy jej na korytarzu szpitala

odkąd zapanował w nim porządek pośród

naszych bezpańskich rzeczy odkąd idealny stwórca

rozstawiał nas po kątach a kto inny kąsał

(CCLVIII Miłosierdzie, OWDR, p. 293) 
["schizophrenia is a black bird / the one from yesterday and the one from today / nesting mainly in the here and now / in always the same poverty of feathers // nobody indeed nobody showered us the double-crossed / with fluff with mystery / and nobody turned us back / when we lost ourselves as the sense of direction // we didn't need it in the hospital corridors / since order set in among / our stray possessions and since the perfect creator / started bossing us around and others started biting"]

Dycki's vulgarisms and argotisms are extraordinary. They are scattered throughout the poet's whole collection of texts and often appear in the context of eroticism; here are a few examples: „wyłachać” [“fuck”], „lachociągi” [“stiffy-puller”], „spermojady” [“cum drinkers”], „lacha” [“hardon”], „dupel” [“arse”], „w pizdu” ["in the cunt"], "bydli moje ciało" ["body fuck"]. They do not break the order of lyric expression, they are not shocking, nothing has anything to do with blasphemy. Unbridled drive is revealed through the obscenity of the text, something that could be described as words of the body in a state of lust.

One of the keywords in this poetry is death. All the critics in a consistent voice point to one of the most important words and one of the most important themes in Dycki's poetry, which is Death. I have not found a single review, nor a single text devoted to this poetry, in which this fact has remained unnoticed. However, I would like to change the direction of reading this motif in Dyckis text a little. The permanent presence of death, signs of disease, decay ("bones" are words that often come back in many verses) seem to serve something else. Dycki could not write a poem about death, because such a poem cannot be written, as was aptly shown by Andrzej Sosnowski on the example of one text from the volume Nenia $i$ inne wiersze $e^{155}$. In order to clarify, such words fall into neighbouring works: „a ja piszę wiersz o śmierci / a ja znowu ten wiersz piszę od początku / i nie umiem go skończyć" " "And I'm writing a poem about death / and I'm writing this poem again from the beginning / and I don't know how to finish it"] (XV, OWDR, p. 24), and in the next one this: „więc znowu piszę ten stary wiersz o śmierci / i wciąż jeszcze nie wiem od czego zaczacc" ["So again I write this old poem about death / and still do not know where to start"] (XVI, OWDR, p. 25). If death comes back here in a variety of ways, it is not in order to be called, developed or poetically worded in such a way as to best describe the experience that connects it. Death is primarily to be addressed by poetic words, so as to move it as far away as possible, unable to be reconciled with its omnipresence. It is impossible to write a poem about death, because a poem about death would have to be death itself. In Ad benevolum lectorem we read these words: „nie gań proszę tych kilkudziesięciu wierszy / które pisałem żeby

155 A. Sosnowski, Liryzm Dyckiego, [in:] Eugeniusz Tkaczyszyn-Dycki i krytycy..., p. 50. 
uciec od śmierci..." ["do not chase those dozens of poems / which I wrote to escape from death..."] (LXXIX Ad benevolum lectorem, OWDR, p. 99).

Dycki's words are words in a state of dialogue, dialogue with themselves, with his own words and the words of others. These are the words on which sometimes surprising intertextual relationships are based. This is how it is in the case of Piosenki o kataklizmach, in the ending of which we can hear Tadeusz Różewicz's voice: „...jak tak dalej pójdzie moje życie / ulegnie małej destabilizacji” [“...if my life will go on like this / there will be a little destabilisation"] (OWDR, p. 315). This song can also not be read without poem CCLXXXIV, in which in turn we hear the voice of Czesław Miłosz and his Piosenki o końcu świata: „innej rozpierduchy bracia i siostry / nie będzie chciałbym się mylić" (OWDR, p. 322). It is also possible here to add words from poem CCCLXVI from the volume Piosenka o zależnościach i uzależnieniach: „(ludzie ludziom zgotowali ten / zielonogórski polmos)..." (OWDR, p. 404), where we hear the voice of Zofia Nałkowska. In other places we can hear Mickiewicz: „może to ja zwymiotowałem całe sielskie / dzieciństwo..." (OWDR, p. 253). These relationships lay out something that could be termed as a micropastiche. There is much more of this in Dycki's poetry, not only in dialogue with tradition but also in the vast area of metaphorical reflection. Pastiche is one of the most important techniques in Dycki's poems This is not limited to the transformation or transposition of words from other poets, its traces can be found also in reference to ancient and old Polish literary forms. Idyll, silva rerum, peregrin, waleta, dirge, epitalamium, priapea, genetliakon ${ }^{156}$ the meaning of these genre names is obliterated and overshadowed by the shadow of pastiche. This pastiche makes their distinctiveness disappear and become forms and genres without shape. There is no need to attach so much importance to them, genology is by no means strong in relation to the literary tradition or the neobaroque nature of that poetry (it would be a great simplification or even a flattening of the meanings hidden in it). The genre forms will only be visible in Dycki's words through the distorted image of the rails of pastiche and irony. Priapea (and many other poems with a genre name) confirms these words: the name of the ancient literary genre becomes the title of a poem about the benefits of onanism an act that is not named anyway („i potrzebowałem kilka razy na dzień zmienić / wodę dla kwiatka odkąd trafił do moich rąk" ["and needed several times a day to change / water for the flower since it came to my hands"]).

156 Wacław Forajter wrote about the subject of genre in Peregrynarz, see W. Forajter, Inwersje, "Pamiętnik Literacki" 2001, vol. 1, p. 200. Forajter talks about the "lost" genres, about their "inverse return". 


\section{Body and rhythm}

The relationship between rhythm and body is inseparable in every text. In the case of Dycki's poetry, rhythm cannot be captured in traditional terms. Let us remember the words of Henri Meschonnic: "[...] the body can only speak in rhythm". Rhythm becomes one of the most important elements of the somatic style and the basis of microanalysis of the text (this is something that goes far beyond Shusterman's assumptions). Rhythm is perceived as a set of qualities, through which linguistic and metalinguistic signifiants create a special semantics, different from the lexical sense (signifiance - significance, which becomes the secondary, complementary value of expression). These features can be arranged at all levels of expression: accent, prosodic, lexical, syntactic (rhythm is spread throughout the text like a theme in a story). In this way signifiants are both syntactic and prosodic. Meaning is no longer contained lexically in words alone. In a broader sense rhythm includes the whole set of prosody features (distribution of accents, intonation), as well as the repartition of syllables in the text and the metric system, if such appears in the text.

Looking at the form of Dycki's poetry we immediately see its (non)repeatability. The poet feels comfortable in short, two-strophe, and most frequently threestrophe forms, often highlighted in addition to a separate verse containing the point. He rarely uses more extensive many-strophe forms. In the preface to the American edition of Dycki's poetry Bill Johnston described the form of his lyrics as "warped or spoiled sonnets"157. These poems do not want to fit into sonnets, they do not want and cannot be put into a conventionalised form: „również po panu / tadeuszu napisałem wiersz erotyczny / ale przegiąłem pałę w stronę / tej samej płci i wyszedł mi sonet" ["also after Pan / Tadeusz I wrote an erotic poem / but I broke the cock on the page / of the same sex and a sonnet came out"] (CCCLXIV, OWDR, p. 404). The versification is also devoid of any regularity, most frequently we meet syllabic lines with a strongly fluctuating number of syllables (from 10 to 15 syllables). Counting them does not make any sense at all. The rhythm of Dycki's poems is based not on metrics, but on systematically exploited stylistic figures: repetition associated with concatenation and displacement. Reading these poems in their entire corpus, we constantly come across the same phrases, permanent repetitions of whole sentences: „jesień już Panie...” [“autumn already, my Lord...”], „w lubelskich domach publicznych moich przyjaciół...” [“in my Lublin friends” public houses...”], „wsłuchuj się w przeszłość...” [“listen

157 B. Johnston, Introduction, [in:] E. Tkaczyszyn-Dycki, Peregrynarz, transl. B. Johnston, Brookline 2008, p. XIV. 
to the past..."], „Z młodszym od siebie nie idź do komnaty...” [“don't lay with someone younger than yourself...”], „żyjemy tak płytko że nie możemy napisać...” [“our lives are so shallow that we cannot write...”], „śpiewaliśmy kiedy umarłeś...” [“we were singing when you died..."], „śpiewaliśmy wieczne odpoczywanie” [“we were singing rest in peace”], „twoja matka jest piękna odkąd choruje powiedziała Hryniawska" ["your mother became beautiful since she's fallen ill said Hryniawska”], „dokarmiam wszystkie wyimaginowane psy” ["I feed all the imaginary dogs"], „każda agresja mojego spolonizowanego ojca" ["each of my polonised father's acts of aggression"], etc. These repetitions do not appear only in incipits, but often within subsequent books of poetry that are distant from each other. We are dealing here with the concatenation of phrases, which are arranged in chains of developed and predicted thoughts. Not only do they affect the monotonous rhythm of interrelated verses, but they also produce an echolalic effect. It is as if the poet listened to his own utterances and insistently repeated them. It is possible to have the impression that repetition is one of the most important rhythmic elements in these poems. But it is completely different - it is rhythm that works in the body and precedes sense, creates repetition. Rhythm in Dycki's poetry begins its uninterrupted work even before the process of meaning; rhythm, quite monotonous, but unique in its repetition, based on strophic construction, on permanent syntactic repetitions, but here this is not about simple repetition, but more about echolalia.

Repetitions of whole clauses or phrases are text strings connecting subsequent works. Repetition of long syntactic fragments links two different and synonymous poems. It is thanks to the repetition of a single line that tells what was not said in the previous work. In these poems we meet all the shortcomings and scarcities, all the miseries of human existence are encountered at once. Permanent depletion of the world of people and objects gives birth to empty spaces, which must be carefully caught and patched up in an incomplete whole, repeating because memory is fragile and selective - here is one of the most important functions of repetition.

Dycki is an absolute master of enjambement. Enjambement is to be found everywhere here, appears between lines and between strophes, but Dycki's line to line enjambements are real masterpieces and are delightful. At first reading the reader can easily "stumble" across them, losing the line of thought and sense of words (enjambement is defined as a rhythmic process based on the noncoincidence of a syntactic unit and a unit of verse ${ }^{158}$ ). Enjambement in Dycki's

158 H. Morier, Dictionnaire de poétique et de rhétorique, Paris 1975, p. 406. 
work comes from the rhythm of speech, and it is from this that it is transferred to the poetry. It is necessary to grasp the rhythm of the line in order to flow smoothly from thought to thought, and yet it is impossible to completely eliminate the effect of semantic surprise, word suspension, retardation, which call up enjambement in these poems.

Dycki's poems are non-rhyming. In some texts there are phonetic juxtapositions that rather give the effect of rhyme, but are not true rhymes. I would rather speak not so much about rhymes as phonetic juxtapositions and repetitions, which in a characteristic way distort and disorganise the rhythmic path and at the same time combine distant semantic entities, causing astonishment, surprise or just laughter: „zawsze miałem szczęście do cycka / czy to była Dycka czy Lewicka...”, „powiem jej o sobie o orzeszku / grzeszku który skrywamy...”, „wyskakiwałem / po kolejną flachę i robiłem lachę”, „trzeba by niegdysiejszy / śnieg czysty i puszysty nigdy nie stajał”, „rozporządzam mówiąc do rymu / niejednym guziczkiem patyczkiem / kamyczkiem” [“I was always fortunate with the titties / whether they were Dyck's or Lewick's...', 'I will tell her about myself, about the grin / sin that we're hiding...' (literally: about the nut / sin...), 'I would pop out for another drink and sucked a dick', 'yesterday's snow / clean and fluffy must never melt', 'Rhyming I dispose of /buttons, sticks / stones"']. Those based on phonetic word combinations join together various semantic units, most often accidentally, embedded through rhythmic impulses of the body involved in the act of writing.

The body in this poetry is ubiquitous, is a mediator and a work, and to the extent that the poet himself becomes body. Its ubiquity is revealed through the rhythm of following texts, the semantics of words (not just those that relate directly to the body, that quite simply name it). In these poems there is a figure of an ultramodern subject - a homeless atopic who constantly searches for his place in the world, and also his identity. 


\section{Sound effects - about Joanna Pollakówna's poems}

Jan Zieliński in the collection published in 2012, Wiersze zebrane by Joanna Pollakówna, writing the 12 stacji introduction to her poetic work, draws attention to the poem Dysonanse and describes it as modern, without rhymes, which - as he states - are actually there, but mostly inaccessible ${ }^{159}$. Indeed, this is a modern poem, and the author sporadically reaches for classical poetic forms, like, for example the sonnet, which appears in the poems Krajobraz (WZ, p. 90), Umierajacej (WZ, p. 101) and Prawda (WZ, p. 429) - even if the sonnet is present here, it is far from traditional strophic regularity. There are poems with similarities to regular poetry, for example Rozmowa $z$ ciałem (WZ, p. 426), in which rhyming verses of seven and six syllables mix with each other (though not completely exactly). There are also other poems where we see traditional distich (including ${ }^{* *} \dot{Z}$ e ta uroda śmiercia jest podszyta..., WZ, p. 491) and also Polish alexandrine (in the epigram Modlitwa o obraz, WZ, p. 483).

There is modern poetry, also because traditional lyrical genres rarely appear here, for example Epitafium (WZ, p. 47), Lament (WZ, 98), Madrygat (O wiośnie) (WZ, p. 252), there is Rytmy (Słowa do pieśni) (WZ, p. 493), there are also poetic prayers and supplications, sometimes haiku-like forms (for example the poetic cycle Pięć zabaw w nic, the poem Łódka - where the clear boundaries between the subject and the object are blurred, all that can be seen in these "poem-events" are ephemeral outlines, the contours of images or experiences which require expression), but the mostly unconventional forms predominate, usually deprived of signs of regularity. Most commonly these are short forms, sometimes "micropoems", miniatures dense with meaning, with a strongly exposed sound structure, rich, expanded phonosphere, to which more space should be devoted.

The author of the preface to the Wiersze zebrane, drawing up his argument based on phonetic associations, in the poem Przytajenie barwy in the word "niepomnie" hears the Latin non omnis moriar, and then in the word "rumowisk" hears the English rumours and French ruminations. Is this a coincidence? Is this interpretative abuse? Or maybe overinterpretation? All these questions must be

159 J. Zieliński, Dwanaście stacji, [in:] J. Pollakówna, Wiersze zebrane, Mikołów 2012, p. 7. All poetry quotations come from this edition. Hereafter, I will mark them with the abbreviation $\mathrm{WZ}$ and give the relevant page number. 
answered firmly: no, and Zieliński - the reader's intuition - in this case is dependable, just as when he reads the extensive intertextual entanglements of Pollakówna's poems, often based on small clues - on one word, on a broken phrase.

The whole rich sphere of voices of this poetry, its sound landscape closely connects with the formation of the senses contained within $i^{160}$. It is even possible to refer to such a definition of poetry which Paul Valéry coined in Rhumbs: "The poem - is an extended hesitation between sound and sense"161. This has nothing to do with music, lyricism or the melody of a poem. When reading these verses, these kinds of metaphors should be pushed aside because they will not tell us very much about the way of forming, generating meanings, speaking about bodies, which without a shadow of doubt are involved in the act of writing. In these few samples of reading demonstrated by Zieliński we are dealing with anagrammatic reading (this is about phonetic anagrams, like Ferdinand de Saussure's), which - as I will try to show - is perhaps one of the most effective ways to expose meanings in the writing model cultivated by the author of Dysonanse.

This is certainly poetry which it is necessary to listen to, but not only because it is somatic poetry sensitive to the senses: touch, sight and hearing, but also smell and taste are ubiquitous in these verses, closely interwoven, and even melted: "całą powierzchnią skóry poczuć kłucie życia" ["feel the sting of life with the whole surface of the skin"], as we read in the poem Samonamowy (WZ, p. 417). This poetry is a special record of somatic experience based on perceiving and describing the external world on the basis of sensual cognition. All metalinguistic and metapoetical reflection here is focused on the senses - there is a myriad of autothematic threads in this verse. The huge multidimensional reality, its indescribable diversity, which is fleeting and understandable "in part" (like in the poem Po części: „Po części bowiem tylko poznajemy...” ["For we only know in part...”]), it is catchy (even if only selectively) primarily thanks to the senses. Let us look at some of the poems which speak about this directly. In Niepoznawalności we read:

Ani ciebie wypatrzę pięcioma palcami

bo ten odpływ wieczny a nie rokuje dna

To jak uśmiechy ślepych: są melodią

opływającą zimnem gardła

160 The sphere of poetic sounds, also for contemporary scholars, necessarily relates to the meaning of the works. Compare, for example M.W. Edwards, Sound, Sense and Rhythm. Listening to Greek and Latin Poetry, Princeton 2002; The Sound of Poetry/ The Poetry of Sound, ed. M. Perloff, C. Dworkin, Chicago 2009; The Sound Studies Reader, ed. J. Sterne, New York-London 2012.

161 P. Valéry, Tel Quel, Paris 1943, p. 79. 
kiedy ręce i usta otwarte pojmowaniu skwapliwemu

a ławice ryb cieniem prześlizgują

nasłuchującym z głębi źrenic [...]

(WZ, p. 44)

["Neither will I see you with my five fingers / as the tide is eternal with no hope for a bottom / it is like the smiles of the dead: a melody / encompassing throats with coldness / while hands and mouths are open to eager understanding / and the fish shoals glide past casting a / listening shadow from the pupils' depth [...]"]

Let us add a quote from the poem Spojrzenie:

Kształtem słonym na dniu jak pisanie mrozu

tak krzepnie wstecz spojrzenie

bo to jest podglądanie czasu jednego w troistej formule [...]

(WZ, p. 45)

["A salty shape over a day like frosted patterns / such is a freezing backward glance / it is after all peeping at time one in the form of a trinity [...]"]

or also this fragment from the poem Mistrzowie, in which the description of works of art requires hearing and sound, in which the objects make their own sounds and in which the sight of the blik gives out a squeak:

Nasłuchiwali czujnie poszeptów przedmiotów;

były mrukliwe plamy stężałego cienia

i ostre piski blików

(WZ, p. 52)

["They were carefully listening to the whispers of objects; / there were curt stains of set shadows / and sharp screeches of bliks"]

and also this short poetic prose $O$ kryształach, which speaks of "reading with fingers":

Kryształy są hałaśliwe. Obwieszczają się dziesiątkiem płaszczyzn i uprawiają głośną autoreklamę wyzyskując w tym celu podstępnie uwięzione promienie światła. W ten sposób tworzą własną mitologię.

Dlatego kryształy czyta się palcami. Ma im to pomóc w odzyskaniu autentyczności.

(WZ, p. 67)

["Crystals are loud. They announce themselves with tens of planes / and noisily self-advertise sneakily using / trapped sun rays. This is how they create their own myths. / Crystals need to be read with fingers. It is meant to help them regain / their authentic status."]

and still more, this metapoetical incipit verse ${ }^{* * *}$ Nazwać to ledwie krwawy strzęp powietrza: 
Nazwać to ledwie krwawy strzęp powietrza

chłód preparatu pod jałowym szkłem

a czasem ćmy gonitwa śmiertelna

gdy świat się skulił w szorstką garstkę światła

Bo jeśli pełność - to może opada

tak szumna jak owadów wirowanie

dalekim graniem bezimienna

barwą bezimienna

a słowa ku niej ociężałe

jakbyś szczyptę zapachu obcęgami chwytał

więc bezimienną w skupieniu uwikłaj

albo w sen

albo w niezasypianie

a jeśli nazwać znaczy strzęp kaleki

powietrza rwać

to reszta jest jak wiatru odpychanie

ptaka zmęczonym skrzydłem

(WZ, p. 79)

["To $\underline{n}$ a $m$ e is like a bloody shred of air / chill of a preparation under sterile glass / and sometimes like a deadly chase of a moth / when the world has shrunk into a coarse fistful of light // For if there is a fullness - then perhaps it falls down / noisily like the spinning of insects / nameless in its far-away sound / nameless in colour / and the words directed at it are heavy / as if trying to pick a pinch of fragrance with pliers // therefore the nameless should be tied up with / either sleep /or sleeplessness // and if n a ming is to tear a crippled / shred of air / then the rest is like the wind pushing / a bird with a tired wing"]

It is possible to continue to give citations, multiply fragments of poems in which there is still talk about the senses and in which synaesthesia constantly returns. In Pollakówna synaesthesia has little in common with modernist impressionism. In this case it is possible to speak of corporeality, which is based on the synaesthesia of perception that causes the senses to be stimulated and engaged in the process of knowing reality. This is something which cannot be named, because it is fleeting, elusive. It is not possible to accurately name this, it cannot be simply imitated, it can only be worked out indefinitely, using all the senses, using the body without which learning becomes impossible. In this poetry the body is one of the most important themes ${ }^{162}$, which is usually defined through somatic

162 Concerning the body and corporeality in Pollakówna's poetry see E. Górecka, Joanny Pollakówny dialogi z ciałem, [in:] Cielesność w polskiej poezji najnowszej, ed. T. Cieślak, K. Pietrych, Łódź 2010, pp. 109-120. Short references to this subject are 
experience, through senses that focus on signs and signs of reality. If the body is directly called up, it is especially in the poems that speak of illness, pain and suffering, for example there are two poems entitled Choroba and there are Ostatnia choroba, Pejzaż $z$ choroba, Więzienia, Rozmowa $z$ ciałem - somatemes appear everywhere describing the suffering body: tissue, cells, blood system, smooth muscle, spasm, pain, pulsing. The excellent poem Semiologia talks about the experience of illness and suffering (sôma and sema - 'body' and 'sign'). The title semiology refers in this case directly to the sign and to the symptoms of illness which is not only human but also of the world that surrounds it. Pain and suffering remain unimaginable, because there is no sign that would help them mark, name, identify, and thus limit and master it. Amongst the poems about suffering and pain, there are many in which rhythm is subdued and gentle, the subject speaking patiently, with unction looking for words that this type of somatic experience could determine. There are also those in which the rhythm is violent, accelerated, becomes pulsatile, spasmatic, as in the incipit line ${ }^{\star * \star}$ Wszystko juz zamknięte... (WZ, p. 219), „wszystko" ["everything”], on short strings, broken calculations perfectly connected with semantics („w skurczeniu, boleniu / w pulsowaniu” ["In contraction, pain / pulsing"]). Likewise, this is what is happening in sound combinations (again this is not about rhymes), for example „zarosły - bólem ostem", the first and third words are phonetically connected, not as distant rhymes; they are rather clashed semantic units that build a picture of the entangled and mutilated body of the thicket, where it is based on several repetitions of words called "pain - pain / thistle" are not rhymes, but just words close to each other in terms of sound. In the second strophe a transcendental juxtaposition of sounds is also equally visible: „Wszystko - lekko - szare mleko - warzy się w szepty” sound combinations evoke images, dense, thickened milk, blurred, self-reflecting words of helpless language referring to pain and suffering. This is one such example where the rhythm of the poem makes it possible to reveal the suffering of the body, where it stamps its mark on the tissue of individual words and the whole text. Rhythm itself is thematised in the poem which speaks of suffering Rytmy (WZ, p. 337), in which the rhythms of the outside world („stukot kól”, „ciężka postoju pauza / i szarpiąca kadencją wyzgrzytany odjazd” ["'the rattle of wheels', 'the heavy pause of a stop-over / and the jerking cadence of the screeched-out departure"]) and

also in the following works: I. Smolka, Małomówność (Joanna Pollakówna), [in:] eadem, Dziewięć światów. Współczesne poetki polskie, Warsaw 1997, pp. 69-76; Z. Zarębianka, Zapisane w języku. Doświadczenie duchowe w nowych wierszach Joanny Pollakówny, [in:] eadem, Tropy sacrum w literaturze XX wieku. Od zagadnień motywicznych do perspektyw hermeneutycznych, Bydgoszcz 2001, pp. 273-284. 
rhythms of nature („przypływów i odpływów pulsowanie” “"pulsation of high tides and low tides"]) collide with the rhythm of a sick body („dygotanie rąk" ["shivering hands"], „oddech jak cichnące wołanie o pomoc" ["breath like a silent cry for help"]) and the syncopated phrase of hope - as the words of the poem say - is lost and moves irresistibly into silence, and so remains unsaid. Also in the poem Rytm (stowa do pieśni) (WZ, p. 493) the title rhythm is also directly related to the body (the pulse of the hand that beats the rhythm).

When it comes to discussion of rhymes in Pollakówna's poems, it is not quite as Zieliński stated that they are inaccurate. There are many texts in which there are regular and accurate rhymes, but they almost never cover the whole of a given text. Often there are rhymes which appear that are similar to assonances and consonances, though they are not exactly identical to them. Their arrangement is based on consonant reflections (echoes) between the repeating sounds in juxtaposed words without maintaining a regular, accurate position. They do not form symmetric patterns, which means that they can connect remote semantic units within one, two, three or more lines. This is probably the legacy of the avant-garde poetry of the twentieth century, especially the Second Avant-Garde. Pollakówna could repeat after Przyboś: "I do not rhyme, I soundify"163, although this soundifying is presented completely differently in her poems. When we speak of the imprecision of rhymes, assonances and consonances, it is important to note the "musical" title of the first poetry collection of 1961 - Dysonanse. The title, as I noted, is "musical", for in the end the poetry is supposed to be sung the second poem of the volume is titled with words taken from St. Augustine's Quit cantat..., is like poetic exergue: poetry/song/prayer. These title dissonances are very important; are discords, discrepancies, disharmony, distortions; and indeed often happen in Pollakówna's poems, and not only in the volume whose title indicates a lack of agreeable tones. Dissonances create the modernity of the poem, in the end they are privileged by dodecaphonic music (Alban Berg, Arnold Schönberg, Anton Webern, in Poland, amongst others Józef Koffler, Tadeusz Majerski, compositions of Tadeusz Baird), which significantly influenced the shape of poetry of the twentieth century, the change in its form of versification, changes in its rhythms, also due to the crisis and the disappearance of agogics, the appearance of Klangfarbenmelodie - the melody of sound colours which for Webern and Schönberg meant that the register of harmonic and rhythmic systems was very reduced and that "instrumental colour", varied in

163 J. Przyboś, Zapiski bez daty, Warsaw 1970, p. 294. 
the case of every musician ${ }^{164}$; "gestures of tonal music" and, which declaratively appeared in the works of Berg and Schönberg, had the purpose of liberating rhythm from regular measure. Here I do not mean the most common translation of the rules of modern music into the description of a poem - this is simply unfeasible, and besides, such a transfer is completely pointless. There are certain similarities between this music and modern poetry, even because of the fact that there is oscillation or interference between the various fields of art. They never exist separately and are not self-sufficient.

Dissonances perfectly define the sound of Pollakówna's poems, which can be seen on many different examples. A variety of juxtapositions and phonetic collisions, consonant echoes or even "connected vessels" (Henri Meschonnic's term) based on phonetics constitute one of the most important elements in the rhythmic construction of these poems, but they are also of great importance in their interpretation. The sound sphere is often linked to the visual sphere. This is the case, for example in the poem Powroty:

Tych zim na śmierć nie zatrzaśniesz

na zapomnienie

po mnie nie -

nie skażesz

i tak nieumieralne w kokonach i brueglach

ciasno zwinięte

na swój czas zdążą niegdysiejszym śniegiem.

Grzbiety wołów w „Godzinkach diuka de Berry”

przychylnie się poddadzą wyciągniętej ręce

i kukanie kukułek - cuculusów leśnych -

na swój czas zdąży niegdysiejsza zgłoską.

Wrócimy w śniegach

kukułek kukaniu

w zawrocie słonecznych zegarów.

(WZ, p. 84)

["It is impossible to shut these winters to death / to oblivion / to not-living - / impossible to consign them / and so in their cocoons and Bruegels / they will immortally lie tightly bundled up / and make it in time with a by-gone snow // The bovine backs in 'Duke de Berry's little hours' / will eagerly follow the stretched out hand / and the cuckoos' cuckoos woodland cuculuses - / will make it in time with a by-gone syllable // We will be back in snow / cuckoos' cuckoos / and sun-clocks giddiness"]

164 The term Klangfarbenmelodie was used by J. Kristeva in La Révolution du langage poétique (Paris 1974, p. 229), making the literary equivalent of "semiotic network of timbres". 
Taken from François Villon and his La Ballade des dames du temps jadis, "snows of yore" indicates the line of interpretation of the poem (the same reference appears in the poem about the incipit ${ }^{* *}$ Jest śnieg, co się podziewa: „pomiędzy myśli biegiem / a niegdysiejszym śniegiem" ["between thoughts running / snows of yore"], WZ, p. 167) - this is not only about the inevitability of passing away, but also the Nietzschean idea of eternal return. The clear reference to painting emphasises the cyclicity of human life: this is about Bruegel and his winter landscapes (for example Hunters in the snow from 1565 - a picture belonging to cycle called The Months or also the Seasons, in which he was to present January, this picture is also known by the title Winter, or still another, called Winter Landscape with Skaters and Bird Trap also from 1565) and about Les très riches heures $d u d u c$ de Berry from the beginning of the fifteenth century, including amongst other things a calendar - a cycle of miniatures depicting 12 months (oxen appear on the illumination presenting March), each containing a solar calendar. The images referred to, of course, point to the representation and repetitiveness of human activities at different times of the year. In the phonetic sphere, particular attention is paid to the often repeated vowels of the sounds of the word "cuckoo", further emphasised by its Latin form "cuculus". This repetition is not limited to mimetic effects, but emphasises continuity and repetition: the "sound of yore" from the Latin word cuculus is frequently and persistently repeated - the semantics and symbolism of the word "kukułka" (particularly in folklore) indicates the inevitable passing (like a cuckoo clock, which constantly counts passing time), in turn phonetics, strings of sounds, sound concatenation points to continuity, lasting, repetition, endless returns. In this text image and sound form a vision of a world based on harmonious recurrences, a repetitive world, which in a special way corresponds to a poem written years later, Dźwięki:

Ten szum, to głosy zmarłych tak brzmią w naszych uszach, jak pył osiadający, kiedy pojazd przemknął.

Jeszcze trochę, a głosy razem $\mathrm{z}$ nami zemrą, do ciszy z nami przejdą,

pył zejdzie się z ziemią.

Może wzbiera nadpamięć

i zestroi głosy

w czysty akord mądrości przejrzystej i mrocznej;

w niej, ponad pojęciami,

nad łopotem słów

ścisły wywód się zleje z cienkim brzękiem kosy.

(WZ, p. 314) 
["This hum is made of the voices of the dead - / that is how they sound in our ears, / like dust settling after a car went past. // In a little while the voices will die with us, / they will enter silence with us, / the dust will reach the ground. // Perhaps meta-memory will well-up / and pitch the voices / into a clear chord of lucid and gloomy wisdom; // in it above ideas, / over the flutter of words / a precise argument will merge with the thin clink of a scythe."]

Recalling the image is not enough, it is necessary to add a pick-me-up that brings phonetic systems to individual texts. Works of art are present in many verses of the poet, but they are never simple ekphrasis, which would be limited to description; direct references to specific creators or works rarely appear in her texts, they are rather signals in the form of names, for example the earlier discussed work Powroty, Światło ( $z$ tematami $z$ Rafaela i nie $z$ Rafaela), Patrzac (Do linorytów Józefa Gielniaka), Zwierzęta Franza Marca, Przerwany koncert (obraz Tycjana $z$ Galerii Pittich we Florencji), Leonardo i jedność czasu. Painting itself is indeed an important topic here, and poems about it reveal the rich aura of artwork in genera ${ }^{165}$. It is possible to describe images, it is possible to talk about what they represent, what emotions they can arouse, it is possible to "make them present". But this is not about the description itself, but above all about the aesthetic experience, the source of which is looking. This is about "yearning", which in poetry includes ${ }^{* * \star}$ Dokad wzywa ta tesknota... or in Weneckie tęsknoty, about contact with the unattainable, the desire for presence emerging from the sphere of unconsciousness, the filling of emptiness, which is borne by a person conscious of death.

The earlier mentioned poem Patrząc is a remarkable example of poetic ekphrasis in which poetry becomes an interpretation of art, in this case this is about a line engraving by Józef Gielniak ${ }^{166}$. It is difficult to recognise in the description the specific works to which this piece refers. Anyway, this is not very important for reading. Of course it is possible to find the numerous themes or motifs that appear in Gielniak's work (cities and buildings with signs of disintegration, plant motifs with sharp flowers, decaying plant remains, anxious visions of sleepiness, hallucinations, even nightmares, rich biological metaphors - amongst others this is about the cycle Sanatorium, Jesień w Bukowcu, Improwizacja, Improwizacja dla

165 Aura is understood in Walter Benjamin's sense of the word. See his The Work of Art in the Age of Mechanical Reproduction, [in:] W. Benjamin, Illuminations, transl. H. Zohn, New York 1968, p. 221.

166 This is a work that was created in February and October 1966, roughly the same time as the poem by Stanisław Grochowiak titled Gielniak. S. Grochowiak, Gielniak, „Kultura” 18-25.12.1966. After Gielniak's death Grochowiak also published a poem dedicated to the artist's memory Zioła Żałobne, „Kultura” 11.06.1972. 
Grażynki ${ }^{167}$ ). Somatic experience dominates in this interpretation of Gielniak's works by Pollakówna - this is about both sensory perception of a work of art (looking) and expression, the manner of expressing that experience. Somatic metaphors dominate here (the city becomes a body - "innervation of the city", "innervation of the cells", "dry weed cough", "cough of the land"), the objects presented on the linocut are animated, embodied. Perception of images is not limited to sight alone, because touch is also important („Jest szukanie / delikatne omackiem palcami po bliźnie" ["there is a search / a delicate swipe around the scar with the fingers"]). The dynamics and imaging of the whole statement also shaped the sphere of sounds written in this text (repetition of a series of vowels, consonant reflection: „miasta” / „wrasta”, „rakiem” / „wraki”). The rhythm of images penetrates the rhythm of the text, and this penetration is accompanied by the sensual, bodily pleasure of perceiving and expressing the aesthetic experience. This is a special ekphrasis, and so a representation of representation (in accordance with the definition from James A.W. Heffernan in his Museum of Words), the presence of images that are not limited to description, but a creative interpretation of the meanings contained in the image. This creative character of reading would not have been possible without somatic experience, which dominated both perception and the expression itself.

The expression of the euphoric state connected with the aesthetic experience eludes description, for this verse is needed, meditation and prayer are necessary. Let us look at the poem Kwiaty:

Z wiązką wiatru

kwiaty dookoła:

płatki z bukietów Redona

przedsenne

Róże Holendrów rosy pełne

świetlne

łaskiście pewne

Auzoniusza kwiaty bagienne

nad Mozelą królewskie cienie.

Spoza czasów spadły na mój stół

róże sine jak różowy popiół.

(WZ, p. 181)

167 Reproductions of Gielniak's work can be found, amongst others, in: Józef Gielniak, edition A. Jakimowicz, Warsaw 1963; M. Hermansdorfer, Józef Gielniak, Wrocław 1975; A. Bloch, Filigranki: na fortepian, ilustracje J. Gielniak, Cracow 1979. 
["With a bundle of wind / there are flowers around: / pre-sleepy / petals from Redon's bunches / luminous / Dutch roses full of dew / gracefully certain / Ausonius's marshy flowers / royal shadows over the Mosel // From beyond times roses livid / as pink ashes landed on my table"]

As in her other poems devoted to art, here are some traces („Redon”, „Róże Holendrów”), but there is also Ausonius the author of idylls devoted to the Moselle and roses (La Moselle, Les roses) ${ }^{168}$. Ausonius is also the author of the extraordinary epigram Écho à un peintre, in which Nymph Echo turns to the painter with these words:

O peintre insensé, pourquoi prétendre à fixer mes traits, et tenter de représenter une déesse inconnue a l'œil des hommes? De l'air et de la voix je suis la fille, et je suis mère d'un vain langage, moi qui possède la parole sans la pensée. Rappelant les derniers sons d'une phrase expirante, moqueusement mes mots escortent d'autres mots. J'habite dans vos oreilles où pénètre lécho et si tu veux me peindre ressemblante peins un son.

["Oh, you silly painter, why are you trying to capture my figure and portray a goddess that hasn't been heard of? I am the daughter of air and voice, the mother of the useless language, I possess words without thoughts. By repeating the last sounds of a burning out phrase, my words mockingly accompany other words. I live in your ears, where echo gets through and if you really want to paint me thoroughly, paint the sound"] ${ }^{169}$

Echo - daughter of air and voice, mother of "useless language", in whose possession we find the word and thought - gives the artist the understanding that the only way to present it is to paint sound. A beautiful epigram that speaks about both the inexpressible and the oscillation between word, image and sound. The thoughts of this epigram correspond very well to the manner of Pollakówna's writing about art. Images are recalled here with just a few words. The sphere of sounds is superimposed upon that: the multiple repetition of the vowels contained in the word rose in the transversal system, as well as the combination of words "pełne" and „pewne”, which is quite simply not a rhyme, the poem is nonrhythmic and only those words clearly collide (dissonance, and not just rhyme), overlap and need to be read anagrammatically. In conjunction with the word "grace", the prayer written in this verse is revealed Pozdrowienie anielskie - the poem itself is arranged in a palimpsest, from which a trace of prayer unfolds, and extensive intertextual relations develop. An almost identical palimpsest is to be found in the prayer-poem $Z$ cienia (WZ, p. 190), which opens the apostrophe to the deity, and the relationship between texts is complemented by one word

168 For the purposes of this text the author chose the French edition: Ausone, Poèmes divers, transl. É. Ducoté, Paris 1897.

169 Ibidem, p. 4. 
written into these verses: „miką świetna ziela pełna / czy ciemna” ["splendid with mica full of herbs/or dark"]. Hence, these poems must be read with particular sensitivity to the sound of words, because it is the sound that extends the meaning fields of particular texts. Writing and/or reading are closely connected with somatic experience, the sound of the words translates into multilevel meaning, revealing an extremely rich intertextual space.

Let us return to the poem Kwiaty. Writing about images demands words of prayer and enters into the sacred dimension. The aesthetic experience in which the object is unnamed, because it is unnameable, is approaching a religious experience in which the name of God is not pronounced (God in Pollakówna's poems appears many times, most often in the form of remarks to another person, but his name is not here: „Bo cała ta niezborność - w wymowie, w sposobie / sama w sobie jest prawdą największą o Tobie" ["Because the whole incoherence - in pronunciation, in manner / is in itself the deepest truth about You"] - as we read in the sonnet Prawda, WZ, p. 429).

Reflection about art (painting, graphics, music, also film) and writing, as already mentioned, is given a lot of space in Pollakówna’s poetry. A good example is the poem Powiew (WZ, p. 392):

Skąd, z czyich dolatuje pól

ten powiew, który myśl roziskrzy

toporne słowa spina prądem

czuły i władczy dotyk ciszy

wyzwala z farb;

lub ścisłą głębię drąży

matematyką dźwięków.

Czy w nas ten powiew spał?

Czy z innych nadlatuje pól

wlokąc niepokojący zapach,

lekkość ozonu, lotną sól?

By nas zagarnąć skrajem skrzydła,

wciągnąć w głęboki oddech ciemny,

w którym wirują jak w zamieci

drzazgi jasności i pył śmierci.

["From which direction, whose fields is the / waft coming from, that brightens the thoughts / piercing clunky words together with a spark / liberating tender and bossy touch of silence / of its colours; / or penetrating a tight depth / with mathematics of sounds. // Was the waft asleep inside us? / Or is it coming from the other fields / dragging a disturbing smell behind, / the lightness of ozone, a volatile salt? / To scoop us up with the edge of a wing, / absorb into a deep dark breath / with splinters of brightness and ashes of death / swirling in like during a blizzard."] 
This is a poem about the birth of art, but also an attempt to define art and the creative act in general (writing, painting, musical composition based on sound, but also a poetic word for which sound is important). This is an attempt to indicate the source of this act, which is of cosmic provenance. Creative thought is born of nothingness and no meaning. The tone in the first strophe of the poem is striking, which rhythmicises the statement, giving it a dynamic character: to-por-ne sło-wa spi-na prą-dem; czu-ły wład-czy do-tyk ci-szy; ści-słą głę-bię drą-ży - we are dealing not only with a series of repetitions of single sounds or consonant reflections, but moreover, overlapping voices are additionally emphasised by strong accents. It could be said that in this way the intensity or the melody of speech is obtained. It could also be said that in this way the rhythm becomes mimetic and imitates the title breeze of the wind, a whirlwind that grabs thoughts, makes them high and sublime. In principle yes, but the fact that the rhythm of the phrase here works against the semantics - words are after all crude, misaligned, uncertain, far from the perfection of meaning. The object speaking expresses doubts in the effectiveness of perfect expression, yet the rhythm of the poetic word produces a completely different effect: the ineffective word sparks out, gains energy and becomes perfect, expressive and accurate. The creative act itself becomes a process oscillating between light and darkness, emerging from the cosmic, infinite abyss and brushing against death.

Written in 1973 the poem Poezja takes on the autothematic topic in a very interesting way:

Lecz ta dzika roślinność nami się karmi

i nawet

gdy wyrasta w kształt nie swój

nieporównywalny

z żadną z myśli które domowe i znane

ustawiamy przedsennie

na błahe turnieje

- w nas ziarno jej posiane

i nasze idee od łodyg dotąd znane

dziwnie się rozjęzyczą w obcą orchideę.

(WZ, p. 228)

["But this wild vegetation feeds upon us / and even / when it grows into a shape that's not its own / incomparable / with neither of the homely, common thoughts that / pre-sleep we set / for petty tournaments / - its seed is sewn inside us / and our ideas familiar up till now / will spread out their tongues into a strange orchid"] 
Poetry is seen here as a world of wild vegetation - in many other poems the poetic word is described in association with natural vegetation and always as a living organism. Words and thoughts born of seed live their own lives, they are difficult to harness, and poetry itself is not subject to domestication, taming. Thoughts are "unending and unintended", as we read in the poem Tożsamość (WZ, p. 242). The tamed or domesticated word becomes limited and predictable, and therefore it calls the world, things and experiences in a conventional and predictable way. The point is to make poetic naming tend to the unknown. The term unhouse from Dylan Thomas comes to mind, and so "leaving home" thanks to which the experience of writing and reading poetry becomes an expedition to the unknown. From the sown seeds of the idea grows a plant that "spreads", and thus proliferates like an organism and like a word to take the shape of an unknown flower. Here appears a significant neologism pointing to, so to speak, the living matter of words, the living tissue of language. This poetic construct, the creature of poetic invention, on the one hand says much about poetry itself, on the other contains the memory of the poetic word, as it evokes Boleslaw Leśmian's neologisms. Neologism is one of Pollakówna's privileged figures, varied in its functions in her verses. Thanks to this the memory of poetic voices is refreshed, as pointed out by Leśmian from the poem Poezja (this is not a simple attempt at imitation, for the meaning and the sound of words also evokes the themes and the aura of the poet's verses) or also Miron Białoszewski, whose voice emerges from the title of the poem Samonamowy - this neologism sounds like the name of a literary genre, just as unique as existential in its pronunciation Leżenia, Przestuchy and many others. And so there are such neologisms which contain in themselves the memory of poetic sounds, the history of a poetic word. There are also others that extend the semantic fields of individual texts, break the rhythmic path of the poem with a surprising sound, and force the reader into creative reading open to meaningful associations - in the poem Tożsamość we read such a phrase: „biegam po krociąkącie swych niesporych racji” [ "I'm running in a whirlpitch of my undersized arguments"], in which the neologism proposes associations with a geometric figure having very many (a multititude of) angles, which in comparison with "niesporymi racjami” ["undersized arguments"] indicates uncertainty, confusion or ambiguity. In the incipit to the verse ${ }^{* * *} W$ konarach tej muzyki... (WZ, p. 356) the word "mgnieniomoment” appears, constructed of two words close in meaning, - is a neologism that doubles tone and meaning, becomes the central word of this short text that speaks of the fleetingness of the moment and the inevitability of passing.

Word-seeds also appear in the poem Zakrzepnięci (WZ, p. 43): 
W pośpiesznym oddychaniu

nim słowo rzecz zbudzi

nim zawiąże owoce po krańce znaczenia

skuleni - ramionami związawszy kolana

przycupnięci gdy słońce żarliwie zasklepia

chłodne pauzy pomiędzy naszymi cieniami

Albo też jeszcze w nocach szczelnych

czułkami słów ku sobie pełzniemy na oślep

a światła odbite od nie naszych godzin

ku rękom ciekną wężliwie

Poza nami nie ma nas

Godziny otwarte na przestrzał

przygięta trawa podnosi się z kolan

słowa - spierzchnięte nasiona

(po mnie owocowanie racz im dać)

Poza nami nie ma nas

["In a precipitant breathing / before words wake things up / before they bud to the end of meaning / hunched - knees tied in arms / crouching in the sun that fervently seals up / the cool pauses between our shadows // Also in the hermetic nights / with antennae of words we crawl forwards towards each other / and the lights reflected by not-our-hours / they snake-like leak towards hands // There is no us outside of us // The hours open far and wide / bent-over grass rises from its knees / words - chapped seeds / (let them fruit after me) // There is no us outside of us"]

There is speak of the body here (an accelerated breathing rhythm) and words that are inextricably intertwined with each other - experiencing meaning is experiencing somatically. This poem has as much eroticism as dreamy vision and prayer. In parenthesis there appear references to Modlitwa za wiernych zmarlych. In the text of the unfinished prayer, apparently, the word "Lord" ["Pan"] is absent, although the phonetic layout in the repetitive like refrain makes it appear twice and also appears anagrammatically written into it: „PozA NamI NIE ma nas”. The same word is also written in the verse separated from text by parenthesis: „Po mnie owocowANIE...” In this text it is also possible to clearly hear the echo of Horace's Exegi monumentum Pieśni 3.30 (the motif is referred to several times in the poet's verses, for example ${ }^{* * * N i e ~ z a r a z ~ w s z y s t k a ~ u m r e . . ., ~ a s ~ w e l l ~ a s ~ i n ~ t h e ~}$ incipit poem indicated by Zieliński ${ }^{* * *}$ Swiatła odchodzacego), except that this unfinished prayer contains a request and hope for survival in the word (string of meaning: seed - fruit - word). In place of the prayer word "resting" a long, fivesyllable word "owocowanie" ["fruition"] appears in the text, which breaks the rhythmic flow imposed by earlier, shorter words. This rhythmical burst draws 
attention to the word itself, and at the same time compels the audience to listen to the phrase, in which the other word is also written through anagram. The anagram is visible and audible, and by its presence the meaning of the text is doubled (secondary, added to the original meaning of the words).

There are other examples of neologisms - this is a figure the poet uses according to the economic principle of saving, consideration, in a carefully thought out way. In Piosenka dla rodziców (WZ, p. 367), the word „podkamienni” appears:

Teraz tam mieszkacie, moi podkamienni, pod mchami, pod wilgocią przekopanej ziemi jedno pod korzeniem, drugie pod kamieniem; przecisnę się do Was przez czarne zmęczenie, przez groźną świetlistość w Waszą obcą bliskość.

["You live there now / my under-stone ones / under moss, under dampness / of the burrowed earth - / one under a root, / the other under a stone; / I will squeeze through to you / through black exhaustion / through threatening lucidity / into your foreign closeness"]

This simple neologism shapes the sound in the work - the phones that make up this word are dispersed tranversally throughout the entire text $\left(p, m, m^{\prime}, n, n^{\prime}\right.$, the group pod repeated five times). Multiple repetition of nasal consonants gives the effect of dark mormorando - after all, we are dealing with a work dedicated to deceased parents, a work that resembles an epitaph. The work of mourning takes on the poetic form of a confession of a dark, telluric theme. The desire to connect with the dead can never come true - here we can perceive echoes of the Orphic myth. The only thing that can be done is to try to tame death - a person joins the earth with the darkness of the underground world, which becomes his new home ("you live"). The threat of death, burial and disintegration of the body is somewhat softened.

And still one more text in which neologisms also play a significant rhythmic role - this is about the poem Przejście (WZ, p. 289):

W niedoprzytomność

$\mathrm{w}$ przedumieranie

- ciemność i zamęt.

Myśli się skłócą

w ognisko zlecą

- pozaobecność. 
Gdzie się dokona

czarna harmonia

w biały czas

sprzed nas i po nas

wtopiona?

["Into uninconciousness / into pre-expiration / - darkness and havoc. // Thoughts will argue / and spark a fire / - beyond presence // Where will be accomplished / the black harmony / melted into the white times / from before and after us?"]

The poem was composed after the work Więzienia, which talks about illness and suffering. The body metaphorically becomes a prison from which there is no escape. This text is characterised by a very dynamic rhythmic course based on multiple repetitions and a refrain from Hymn to Love from the First Epistle to the Corinthians. The accelerated and fluid rhythm gives the impression that the text is almost shouted, expressed in full violence, and its message - despite repeated biblical allusions - leaves no hope whatsoever. This thread develops in a similar rhythm and at a similar tempo to the quoted poem, Przejście. The title indicates the crossing of an elusive, difficult-to-determine barrier between life and death. The rhetorical questions from the last strophe remain unanswered. From the beginning the rhythmic flow is formed by two five-syllable neologisms („niedoprzytomność" and „przedumieranie”) - long words, to which the word "pozaobecnośc", which closes the second strophe, is added. They give the effect of rhythmic elongation of the phrase (in addition, underlined by the same, identical metre - five syllables), and their semantics unambiguously link to the difficult-to-name state of fear and subconscious threat.

The names of the senses are constantly returning in Pollakówna's texts, the senses are the basis of the bodily perception and expression of the world. Sometimes they intertwine, overlap, enter into interdependence. They are either the subject of poetry, articulated explicitly or indirectly (metaphor and metonymy), as well as the basic instrument of their formation. The somatic experience of the world and the sensual focal point are already present in the poet's early verses, and their power does not go away until the very end of her work.

From this perspective it is worth looking at the poem Przytajenie barwy (WZ, p. 51), written in 1961:

Cisza na barwy rozbita

opada skrzydełkami

owadów

kolorem tęczującym

wirującym.

Bączek dziecinny po podłodze 
ze śmiechu

zatacza się:

jużpociszy

pociszy

szy szy.

I kurz drogocenny

tęczuje dostojnie

strojnie

na ton wysoki

strojony

lecz zaraz ciemno

w brodatych akordach

zwiśnie.

Kurz

nie wódź na pokuszenie!

Barwy przytajenie - cisza

białość - dźwięków pseudonim.

["Silence broken into colours / falls down like the wings / of insects / like a twirling / rainbow colour. / Children's spinning top / reels on the floor / with laughter: / hushing / hush / sh, sh. / And the precious dust / proudly rainbows over / rich / to a high-pitch / tuned / but presently darkness / in bearded chords / will be suspended. / Dust / do not lead into temptation! / Colour ablation - silence / whiteness - the synonym of sounds"]

This is a "poem-episode" or "poem-event", perceived and fixed in seemingly unimportant, innocuous poetic words, a fleeting event in which the perception of sounds and colours plays a decisive role. The sound itself is imitated by continuous writing in two consecutive lines and additionally the repeated onomatopoeia "szy”. It is not just the notation of sound, but a record of speech in which the individual words merge. The next repetitions go towards total silence, as the sound is muted and as the spinning droplet moves, as it is "concealed", and thus hides its colour. Throughout the text whole series of single phones, groups of phones are repeated - a network of consonant reflections is formed, which forms a gentle but at the same time dynamic rhythm of the verse. The rich layer of sound combines with the semantic domain (high-pitched tones, chords) - it is a true symphony of sounds, meanings and colours. Aesthetic experience passes into epiphany, delight in the perfection of the fleeting moment. It is like contact with the Absolute, and it must not be said, because it is unexpressible, and that is why at the end of the text there is a quote from the Lord's Prayer. The title colour hue goes into silence, and white becomes the pseudonym of sounds - the visible melts with the audible. 
The sphere of sound plays a capital role in Pollakówna’s poetry - sounds shape the rhythm of texts, influence the shape of textual meanings. The sounds that so often appear in these verses have little in common with musicality or the lyricism of a poetic word. These metaphors emphasise the aesthetic side of poetic text (in this way they are close to the old word "miłodźwięk" [ "euphony”]), but on the other side they play a decisive role in generating the meaning of individual works. Pollakówna's poems are like chambres decho, out of which rhythm flows and resonates in the body of those who read these poems. 



\section{Listening as a somatic experience - about Edward Pasewicz's verses}

In the vast collection of the latest Polish poetry, there are many creators ${ }^{170}$ whose poems need to be listened to in order to hear this one, only voice of the poet who is unique every time. It is exactly this voice which is a real stake in the game of modernity. Edward Pasewicz has full awareness of this - he is one of the most interesting poets writing "poetry to listen to" today. In his Matka Marianna od pedałów, there are words that could be put in an excerpt for the collection of his texts: „Muzyka głosu jest jak punktualizm..." ["Music of the voice is like pointilism...”], or also „Najpierw jest dźwięk, później oblepia / się sensem.” ["First there is sound, later we drape it / with sense."] (a sound that has something perfect in it, its feature is purity, and the meaning "clings to it", polluting it like dirt) ${ }^{171}$. Pasewicz is the author of the excellent Sonata o rytmie from the volume Th. It is worth recalling this in its entirety and taking a closer look at some of his other texts (this poem was incorporated into the volume with the significant title Muzyka na instrumenty strunowe, perkusję i czelestę):

Podnosisz stopę, a mnie się przypomina, punkt spoczynku, „płynące teraz”, ale nie żebym przezywał, bo jest ciągle obok, co otworzę usta ucieka, histerii już się oduczyłem, więc mnie „płynące teraz” już nie uwodzi jak dawniej, raczej ten układ „leve-frappe”, uderz, spocznij. Mam nowe rany na twarzy, czy już mówiłem? Nić logiczna, od twoich kroków, do mojego wzroku i piłeczka co rzucona robi, taak, tak tak tak ta ta $\mathrm{t}$ (bo biała nitka na twoim policzku, gdy cerujesz mi spodnie, wyraźna jest

170 Jerzy Wiśniewski recently wrote about poetic styles of listening to poets of older generations. See J. Wiśniewski, Ku harmonii? Poetyckie style stuchania muzyki w wierszach polskich autorów po 1945 roku, Łódź 2013.

171 I quote based on: E. Pasewicz, Muzyka na instrumenty strunowe, perkusję i czeleste, Poznan 2010, p. 63. Further quotations from this volume I indicate with the mark MnI. Quotes from the volume Pałacyk Bertolda Brechta (Cracow 2011) I give with the mark PBB. 
i nie daje spokoju).

Obiegnik, tryl i przepłyń mnie proszę,

kiedyś była śmierć najlepszym spójnikiem

a teraz co? Uderz, spocznij,

argument na nie, w fartuchu ordynatora,

zwrócili państwo uwagę jak to się kończy?

W sterylnych pomieszczeniach stukot

kopyt, nie wrócą, bo nie mają dokąd,

echa co zawsze sprawiają wrażenie,

że są połową jakiejś całości.

I nawet gdybym znał ten ruch, nic mi

nie pomoże, ten ruch nie gasi, nie znaczy, nie pali,

bo to twoje przejście z kuchni do pokoju,

szybkie i kocie, tak, że mi umyka,

ten moment kiedy podnosisz stopę i ona

znowu opada.

Czas jest liczbą ruchów według wpierw i później.

(MnI, p. 76)

["You lift up your foot and I recall / libration point, a 'current flow', but I don't mean / to tease, it is still close, / whenever I open my mouth it escapes, / I have learnt not to panic, so / 'current flow' doesn't seduce me as it used to, / as in the 'leve-frappe' system, hit and relax. / I have new wounds on my face, did I mention it? / The logical thread from your feet to my / eyesight and the ball that goes / taack, tack tack tack ta ta $t$ when thrown / (because the white thread on your cheek / when you are darning my trousers is stark / and bothering). / Slide, trill and swim through me, please, / once death was the best conjunction / and now what? Hit and relax, / the argument against, in the senior registrar's coat / have you noticed how it usually ends? / the rattle of hooves in sterile rooms / they won't come back - they have nowhere to go to, / echoes that always give the impression / of being part of a bigger unit. / And even if I had known this movement, it wouldn't / do, because it doesn't extinguish, mean or burn / because this journey of yours from the kitchen to the living-room, / fast and cat-like, so it escapes me, / the moment when you lift up your foot and / it drops down again. // Time is a number of movements according to before and after.']

Pasewicz not only writes poems to listen to but he himself also listens attentively, and listening itself is a somatic experience, closely linked also to the rhythm that is in his poems is thematised, subjected to philosophical reflection, developed in many different ways (the very word "rhythm" appears in these poems many times in various thematic constellations) - this is one of the most interesting examples in the latest Polish poetry. In Pasewicz, the matter of rhythm is linked to music and language, and language rather with the body, which can be read in the sentence closing Strofki dla Siwego, which sounds rather like a fragment of 
autothematic speech: „język jest w końcu niepochwytnym ciałem” [“Ultimately, language is an incomprehensible body"] (MnI, p. 64).

The manner in which we listen to Pasewicz could be described as poetic close listening, where this is about listening to the world, sounds and words (careful listening into the words, into their sound, into their deep meaning), but also listening to this strange inner radio broadcast, which constantly emits thoughts, ideas, single words and only sometimes is this possible to catch and contain in the form of a poem („rój głosek w mózgu, wciąż się powiela” ["swarm of sounds in the brain, continuously duplicating"], as we read in the poem 11 lutego 2002, MnI, p. 27). In turn listening to poems by Pasewicz (but also poetry in general) can be described like a reading close listening, which favours poetic sound and sets itself in opposition to the close reading of the American New Criticism - this opposite paradigm of reading puts particular emphasis on all of the sounds in the text, its rhythm and their relation to semantics ${ }^{172}$.

According to Roland Barthes listening is a "psychological act", which "can be defined only by its object"173. The researcher indicates several types of listening, two of which seem particularly important for these considerations. The first is decryption, where the listener tries to capture certain characters, listens according to certain codes, as if he were reading. The second - considered by Barthes as the "most contemporary" - consists of a kind of listening which is oriented not on signs, but above all on who speaks. This type of listening develops in the intersubjective space and is moved into the realm of the subconscious. The phrase "I am listening" in this space also means a kind of reciprocity, so also "listen to me". The act of listening itself is associated with rhythm, which is the basis of all speech and makes listening also a form of creating ${ }^{174}$. This is something that could be considered one of the most important principles of listening to Pasewicz's poems, which while reading it is necessary to create.

Jean-Luc Nancy in his excellent book À l'écoute ${ }^{175}$ undertakes true consideration of hearing, binding this phenomenon to rhythm, the body and the subject, and proving that rhythm based on sound and sense shapes the subject's space being is inextricably bound to listening (the title of the book comes from the formula être á lécoute - "being-listening"). In turn, André Spire, speaking of poetic pleasures and muscular pleasure, remarks: "To listen is also to speak"176. The

172 See Ch. Bernstein, Introduction, [in:] idem, Close Listening, Oxford 1998, pp. 3-26.

173 R. Barthes, Ecoute, [in:] idem, Oeuvres complètes, vol. 5, Paris 2002, p. 340.

174 Ibidem, p. 343.

175 J.-L. Nancy, À l'écoute, Paris 2002.

176 A. Spire, Plaisir poétique et plaisir musculaire, Paris 1949, p. 55. 
words heard are called into existence, and this process is repeated in every act of writing and reading, in which the participating body is endowed, so to speak, with a muscular sensibility.

As can easily be seen in Pasewicz's poetry, listening is linked with music; there are references to various musical genres here (Pierwsza piosenka [First song] - MnI, p. 11; Sonata o rytmie [Sonata about Rhythm] - MnI, p. 76; Piosenka kamiennych bębnów [Song of stone drums] - MnI, p. 168; Dubstep [Dubstep] - PBB, starting from page 6 , nine works with the same title numbered from the end), to names or to titles of individual works (Prokofiev andante sognando-MnI, p. 14; Mahler forever - MnI, p. 24; Bach - MnI, p. 79), and there is also the rich sphere of music lexis („decrescendo” - MnI, p. 23; „Obiegnik, tryl...” [“Turn, trill...”] - MnI, p. 76; "ostinato to najprostsza droga do świętego porządku" ["ostinato is the straightest road to holy order"] - PBB, p. 52; Kwartet, [Quartet] „oratorium” - PBB, p. 55; „Codzienne stacatto" ["Daily staccato”] - MnI, s 43; „puktualizm” ["pointillism”], "stretto”, „kanon alla terza” [„canon alla terza”] - MnI, p. 63; „tercja” [“third”], „septyma” ["seventh"], „flautando" [,flautato”] - MnI, p. 78; „kamerton” ["tuning fork”], „Bach” - MnI, p. 79; „allegretto i scherzo i cantabile” - MnI, p. 91; „Adagio religioso” - MnI, p. 148; „Dankgesang” - MnI, p. 182). For Pasewicz himself poetic writing is, it seems, musical - it should be heard, to hear how he himself plays, to understand his poems. Listening and repetition also expands into other languages - foreign names and phrases in German, Spanish, French, also Danish (the word "smuk" repeated in 22 rytuały smutku i zazdrości), Hebrew onomatopoeia taken from the Bible, fragments of the Tibetan mantra Green Tara and many others. Their repetition is unambiguously linked to the experience of the place, the memory of places and the memory of voices and sounds. Listening to sounds is generally a characteristic feature of Pasewicz's writing - „Szelest tej kurtki” [“The rustle of this jacket"] (Pierwsza piosenka, MnI, p. 11), which cannot be recognised, listen to the unclear ,języka-szumu" ["language-noise"], in which the sounds blur together "galaretowatym dźwiękiem” ["a sound jelly"] (Deszcz na Czajczej, MnI, p. 15), listening to the sound coming from the kitchen that is becoming „dźwiękiem wielokrotnie złożonym" ["a repeatedly composited sound”] (Książeczka dla Marka, MnI, p. 28) or "scratching" coming from the next room (Rozciagnięcia, MnI, p. 33). Persistent listening to the world, listening to its sounds, leads in the poem Mahler forever to the articulation of the particular desire encapsulated by the rhetorical question: „Czy mógłbym dźwięk przełożyć na dotyk?” ["May I change sound for touch?”] (MnI, p. 24) - the somatic character of Pasewicz's texts is contained in this question. The body is one of the most important themes that appears in many works and is accompanied first and foremost by sounds, but also by touch and 
sight. The latter is the sense that also plays an important role in Pasewicz's texts. We even have to deal with something that could be termed as a visual focalisation, based on which poetic micropictures, similar to miniature paintings or photographic images recording certain trinkets in close proximity, details that are usually imperceptible, skipped, subjected to elision („czarno-białe nasionka rośliny leżą na watce / i kiełkują" - ["the plant's black-and-white seeds lie on cotton wool / and sprout”] MnI, p. 33; „błonki liści wyschniętego kwiatu, / który stoi na parapecie” ["leaf membranes of the dried-up flower / standing on the windowsill"] MnI, p. 46).

There is the whole wide sphere of homosexual eroticism in these poems descriptions of erotic acts that are literal and even verismo (for example Poczatek, O potrzebie ponowoczesnej pieśni religijnej, Gry i zabawy). Without a shadow of a doubt this is something that - as Joanna Orska rightly said - is unprecedented in Polish lyricism ${ }^{177}$. Here there is no metaphorical displacement of meanings, it is full of openness, completely unconstrained by any rules of appropriateness or convention. Nothing prevents direct discussion of this experience.

Let us return to hearing. In some texts it is possible to clearly hear the echoes of other texts - this is how it is in Autobus czerwony:

Piękny chłopiec.

Piękny mocny.

Piękny a śmiertelny.

Ludzi w autobusie

patrzą na niego.

Pełno jest spojrzeń,

które go taksują.

Kobiety i mężczyźni,

dzieci i martwe przedmioty.

Och, one szczególnie.

Pełen martwych przedmiotów

jest ten autobus, który

wiezie chłopca.

I wszystkie spojrzenia

są jakby jednym spojrzeniem,

może dlatego, że jest tak realny,

za duża jest koszulka

za duże są buty?

Spojrzenie ma rozbiegane

szczególnie na przystankach,

177 J. Orska, Posłowie, [in:] Muzyka na instrumenty strunowe..., ed. E. Pasewicz, p. 190. 
jakby czekał i wypatrywał

przy kolejnych wiatach

kogoś, kogo zna lub

kogoś, kto zna jego.

Lecz dojeżdża sam,

i nie zamienia

$\mathrm{z}$ nikim ani słowa.

Piękny chłopiec.

Piękny mocny.

Piękny a śmiertelny.

Pełne są jego spojrzeń

nasze nerwowe spojrzenia.

(MnI, p. 30)

["Pretty boy / Pretty and strong / Pretty and mortal. / People on the bus / are glancing at him / Glances everywhere, / eyeing him up. / Women and men / children and lifeless objects. / Oh yes, these ones in particular. / Full of lifeless objects / is that bus / which carries the boy. // And all these glances / are just like one glance, / perhaps because he is so real, / is it his top that's too big, / or his shoes? // He is casting glances around / particularly at bus stops / as if he was waiting and searching / at every carport / for someone he knows / or someone who knows him. // But he arrives alone / and doesn't exchange / a word with anybody. // Pretty boy. / Pretty and strong. / Pretty and mortal. / Full of his glances are / our nervous glances."]

What can be heard in this text-palimpsest? The first line is the well-known postwar song Czerwony autobus [Red Bus] sung by Andrzej Bogucki, and also in this song the bus is a place of sighs of love (indeed strongly within conventions and not going beyond the norms accepted by socialist society), just that this was for a girl, not like in Pasewicz, for a boy. This reference introduces a seemingly comical, slightly grotesque effect (this song heard today cannot be received in any other way), but from the first lines the text thickens in meaning through references to the Trisagion. The supplication "Holy God" turns the text into a prayer, while the prayer is about "the beautiful boy" to whom they are looking with such lust. "Taksować", a way of looking at people - is an unusual word today. „Taksować" is to judge someone, looking at them carefully but also to guess, appraise - in Aleksander Wat's poem W barze, gdzieś w okolicach Sèvres-Babylone (z kiczów paryskich) „modelka Toulouse-Lautreców / babilońska wszetecznica” [ "model of Toulouse-Lautrec / Babylonian harlot"], looking for customers, does this to two older men sitting in a bistro. And in both texts this kind of looking is laden with the economy of lust. Erotic tension is built in Pasewicz's work through an exchange of views. In the last verses, this supplication is repeated and additionally 
we hear Sanctus („Pleni sunt caeli ...”). A popular song about Warsaw from the postwar period is connected with sacred texts - is this blasphemy? Not at all. A superb text whose theme is homoerotic rapture compared to religious experience. This likewise happens in the poem Matka Marianna od pedatów, where erotic experience is associated with prayer The Lord's Prayer: „Leżymy ogromni w powszedniej pościeli" ["We lie enormous in the daily bedlinen"] (MnI, p. 63).

It is necessary to listen to these texts, the title, a phrase or a single word evokes a musical work or other texts (for example Adam Mickiewicz's interesting travesty Nad woda wielka i czysta woven into the text of the poem Przed szyba wielka i czysta, or also the echo of Przesłania Pana Cogito by Zbigniew Herbert „idź, dokąd poszli tamci, cholera idź i jedz" in Hęryk napręża plecy. Nie ma winy). It is significant that among the intertexts of Pasewicz's poetry, those voices of others, repeated, transformed, parodied, are derived from the Bible, from high culture, and those that are taken out of pop culture. They do not collide on the basis of contrast, contradiction, rather on the contrary - they are harmoniously linked together in a coherent whole. The memory of voices goes back to tradition and history, but it is also related to day-to-day life and the present. In order to narrate a dream about Jehovah, it is necessary to write a sonnet (Senariusz, MnI, p. 34), in which listening also plays an important role. It is necessary to listen to the title word "senariusz", in which through anagram we can read and "scenariusz" ["scenario"] and „sen” [“dream”], and also „sennik” [“dream book”]. The associative vision of dreams in this way becomes a scenario written by structured and ordered unconsciousness. Reading and listening to names in everyday life, the names of the various companies appearing on and in advertisements, gives the effect in the form of the grotesque song Hilti! Hilti!:

Hilti, kupiłem pręt gwintowany. Twoje magazyny na Łopuszańskiej są piękniejsze od tych, które ma Bimerieux na Żeromskiego.

Pamiętasz mnie, Hilti? Pochodze z Instytutu Genetyki Człowieka PAN na Boninie, to mnie kocha Zepter International, to mnie kusi Fagor-Gastro (ulica Palmiry 186) z Czosowa, to ja czeszę się na Wieniawskiego 18 i jadam, na Wolnej Wszechnicy 5, kruche naleśniki. To ja uciekłem z deskami z Despolu i biegłem przez Kampinos, aż dorwała mnie Manta-Multimedia i oplotła swoimi mackami. Byłem gołębiem, pamiętasz, Hilti, i wiem, że Cargoforte mnie nienawidzi i Nelson Mandela, ale kocha Renault, dlatego będę pił z tobą caca-colę, Hilti, urządzę 
potańcówkę w magazynach normaliów Tech-Daty,

na Inowłodzkiej, będziemy pili wódkę, aż

zabierze nas Tirsped z ulicy Fleminga i powiezie

do Michałowic, i będę kochał cię Demarcie, Hilti,

i powiem ci Sanofi-Aventis, i to będzie jak ślub.

(MnI, p. 157)

["Hilti, I bought a threaded rod, your / warehouses on Lopuszanska are nicer / than the ones of Bimerieux on Zeromskiego. / Do you remember me, Hilti? I am from the PAS Institute / of Human Genetics in Bonin / it is me, who is adored by Zepter International, tempted by / Fagor-Gastro (Palmiry Street 186) from Czosow, / I am groomed at Wieniawskiego 18 and eat / crispy pancakes at Wolnej Wszechnicy 5. / It was me, who fled with Despol's planks / and ran through Kampinos until Manta-Multimedia collared me / and ensnared in its tentacles. I used to be a pigeon, / you remember, Hilti, and I know that Cargoforte I hates me, so does Nelson Mandela, but Renault loves me, / and that is why I will drink cacacola with you, Hilti and organise / a dance in the Tech-Data warehouse of regularities / we will drink vodka on Inowlodzka until / Tirsped from Fleming street will pick us up and drive / to Michalowice, and I will love you Demart, Hilti, / and will proclaim SanofiAventis, and it will be like a wedding."]

This song addressed to Hilti, a company that produces equipment for the building industry, becomes nothing but a postmodern Song of Songs, or as a postmodern epopee comparable with Odyssey or a tale comparable to Ulysses. The hero of the song is a "posthuman", a depersonalised genetic creation that experiences the postmodern market world, and Hilti is the betrothed with whom a marriage is to be made with the words Sanofi-Aventis, sounding like a mysterious formula form a foreign language (notated in italics in the text), but in fact, they are the names of pharmaceutical companies. These names are particularly prominent, and their sound is linked to the experience of postmodernity or even - as Marc Augé would like - surmodernité, in which man, without his own will, is constantly pushed into a variety of “non-places”. The name „Manta” - through anagram - evokes „mątwę” ["cuttlefish”] („oplotła swoimi mackami” ["braided in her tentacles”]). All of these company names are like antique heroes, mythologised as the cycling race of the Tour de France, where subsequent stages are like skirmishes, battles and adventures of heroes, and they themselves have nicknames like those taken directly from the epopees or heroic songs, as shown by Roland Barthes in Mythologies.

Music for Strings, Percussion and Celesta (or also Concerto for Orchestra; Music for Strings, Percussion and Celesta) - is a work by Béla Bartók from 1936 made of four movements: the first movement is Andante tranquillo, which is a fugue for strings, the second - Allegro, third movement - Adagio and fourth - Allegro molto, which is a rondo. Of course there is no question of simply transferring the structure of the indicated composition to Pasewicz's volume. On the other 
hand, however, it is impossible to understand the whole of such a composed volume without listening to Bartók's masterpiece. This context of a musical work is crucial to reading the entire volume because it immediately draws the attention of the reader to the act of listening and to the experience of listening. It is necessary to listen to this poem to discover the voice, indeed, just the voice, given that Sonate... precedes Traktat o gtosie in this selection.

If we were to look in the history of Polish poetry for "music for", in the first place Jarosław Iwaszkiewicz comes to mind and his Music in the Evening, which consists of two parts: Music for Quartet and Music for Orchestra - the first of the cycles corresponds to the title composition, consisting of 36 text "miniatures" (almost all, with a few exceptions, are octostiches), created - it would seem with a string quartet in mind; the second contains extended texts, even with several parts "polyphonic" poems as if written for an orchestra. Music in the Evening - on account of the title and subtitles, numerous allusions to musical compositions, the prominence of the role of sound in the whole volume - was definitely a text intended for listening. Iwaszkiewicz came up by chance because in Sonata o rytmie it can be seen, and to be more precise, an allusion can be clearly heard to the poem Do siostry from Iwaszkiewicz's volume (I have in mind the words „stukot kopyt” and „echa”, which appear in the last two lines of Iwaszkiewicz's aforementioned octostich: „Lekko kołysał echem ucho moje / Stukot przed domem kopyt naszych koni" ["Gently rocking my ear with an echo / The rattle of our horses' hooves on the porch"]). I am not entirely sure whether this is a conscious allusion, but three words are repeated here, furthermore the theme of Iwaszkiewicz's poem, which is the inevitability of passing, remembering that which has irreversibly passed - which is similar in Pasewicz, although the theme is realised in a completely different way. Recalling the past, Iwaszkiewicz appeals to sleep, in Pasewicz everything happens in a daydream, here and now.

This excellent poem is a word registration of a fleeting moment, a microscene (and even a series of sequences) from life maintaining constant motion and continuous passing. Continuous, eternal movement, which - as Aristotle claimed never started and will never cease to exist, is closely connected with rhythm and with time. Sonata opens with a quote from Aristotle's Physics (Book IV, 11, 219 b, "Co to jest czas. „Teraz"' [ “What is the nature of time. "Now"']), arranged in three lines, as if a rhythmic poetic text, in such a way as to emphasise the importance of every particle of this quote ${ }^{178}$. In Kazimierz Leśniak's translation, this quote

178 Grzegorz Jankowicz draws attention to this in his postword for this collection of poems. See G. Jankowicz, Posłowie, [in:] Muzyka na instrumenty strunowe..., ed. 
is as follows: „Albowiem czas jest właśnie ilością ruchu ze względu na «przed» $\mathrm{i}$ "po»"179 ["For that is what time is: a number of changes in respect of the 'before' and 'after"'], which Pasewicz gives poetically in the following form: „Czas jest liczbą ruchów według wpierw i później" ["Time is the number of moves according to first and later"]. Sonata - on the basis of self-assessment or travesty of the poet's own words - is repeated in other works (in Pruski poemat: „Więc co wyrażałeś / traktatem o rytmie? / Unieś stopę, uderz", and also in Wskazówki dla zbieraczy szyszek: „Jesteśmy transakcją między przed i po?” - here with a question mark, as if to make sure it's true; the word "transakcja” ["transaction”] cannot be reduced here just to economic significance, it is rather more about "accomplishment", and so "jesteśmy dokonaniem między przed i po", "dokonujemy się między przed i po" ["We are an accomplishment between before and after"]). Aristotle's "before" and "after" do not appear in the temporal sense, they are related to numbers and motion, understood in the kinetic sense ${ }^{180}$. Rhythm is based on the experience of movement - also in Pasewicz this is about "first and later" in motion, but not in time. Movement here is exposed from the first words: „Podnosisz stopę...” ["you raise your foot..."], and then the sequence of moves "leve-frappe" and the ball rolling on the floor, whose sound is onomatopoeically reflected in the text until its motion is frozen: "taak, tak tak tak ta ta t". The whole poem is also undertaken in motion between "before” and "after" (from the first phrase: „Podnosisz stopę...” to the last, closing the main text: „... podnosisz stopę i ona znowu opada" - Aristotle's words constitute a kind of appendix, and they are clearly separated and even separated as a summary or complement of the entire text $)^{181}$.

E. Pasewicz, p. 203. Jankowicz aptly indicates the context of the analysis of Aristotle's definition by Martin Heidegger in Being and Time.

179 Aristotle, Fizyka, transl. K. Leśniak, Warsaw 1968, p. 134. It is worth mentioning here the entire paragraph, which precedes the phrase in the foreword: „Gdy z jednej strony doświadczamy «teraz» jako jedności, a nie jako zachodzącego «przed» i «po» w ruchu, ani jako tego samego «teraz», lecz jako w stosunku do pewnego «przed» $\mathrm{i}$ "po», wówczas się zdaje, że nie upłynął żaden czas, ponieważ nie było ruchu. Z drugiej natomiast strony, gdy możemy stwierdzić «przed» i "po», wtedy mówimy o istnieniu czasu" ["When, therefore, we perceive the 'now' one, and neither as before and after in a motion nor as an identity but in relation to a 'before' and an 'after', no time is thought to have elapsed, because there has been no motion either. On the other hand, when we do perceive a 'before' and an 'after', then we say that there is time., Aristotle Physics transl. R.P. Hardie and R.K. Gaye, Digireads Overland Park, Kansas 2006].

180 T. Roark, Aristotle on Time. A Study of the Physics, Cambridge 2011, p. 107.

181 „Podnoszenie stopy”, despite what Grzegorz Jankowicz stated, does not refer directly to rhythm. If anything this could have something to do with metre, but in this text 
Raising and descent in motion, rising and falling, anti-cadence and cadence. This movement however is unknowable and elusive, "nie gasi, nie znaczy, nie pali” ["does not extinguish, does not mean, does not burn"], is impossible, there is no way to catch the passing time. Rhythm itself, the domain of experience, and not the possible practical applications, is as unknowable as poetry that emerges from the unknown. Rhythm starts, activates and moves thoughts. To speak about this we do not need poetry, but sonata (Pasewicz, in giving titles to his poems, sometimes uses the names of musical forms: Rondo, are different songs, and there are also canticles). Here - assuming, of course, that such a transfer of musical form to poetry is possible only as a metaphor - this would rather be a sonata da camera, finishing with a coda in the form of a sentence from Aristotle. But why sonata? Perhaps due to the closed, rigorous and coherent structure that seems most appropriate to the idea of this text (successive sequences of images and thoughts). Or perhaps because of its narrative implications, the sonata is interpreted in the context of a narrative musical genre - in such a view, the sonata is a metaphorical representation of perfect human action; it is narrative action, because it follows a set sequence of events that proceed to a clearly defined goal ${ }^{182}$.

Referring here to Pasewicz's autothematic statements, one might ask what this work is supposed to express. The point is not expression, because this is not about expression but about an attempt to embrace what is fleeting and elusive. In Poemat pruski we find the true answer to this question: „Co pomyślę ten świat, już znika, / tylko go nazwać, a przestaje trwać" ["What I think of this world, is gone / I just name it, and it stops being”] (MnI, p. 84). All forms of expression are always defective, because all signs are shaky and uncertain, which is clearly expressed in the words of Poemat pruski (p. 84).

In formal terms, Pasewicz's poetry is strongly differentiated, apart from texts whose titles are derived from names of musical genres there are also others, for example Wiersz osobisty, Wiersz dla Szymona Haszka, Esej o uważności, Wersy dla panny Babbit, Elegia dla Wiery Pasewicz, List, Ballada o szmirze, Pruski poemat - strongly varied genre forms, which correspond to strongly differentiated versification. Blank verse is definitely dominant here, but there are also references to traditional verse forms: sonnet (the earlier mentioned Senariusz), which forms classical sonnet as only 14 lines in the arrangement 4424 , in a few poems unrhymed distich appears (for example Piszemy opere, Książeczka do

this is about movement, and not measured verse. See G. Jankowicz, Posłowie, [in:] Muzyka na instrumenty strunowe..., ed. E. Pasewicz, p. 204.

182 J. Hepokoski, W. Darcy, Elements of Sonata Theory, Oxford 2006, p. 252. 
pokrewieństwa, Po polsku, Zupa rybna, but in some texts it is also interwoven and placed next to other verse forms), in a few others there is unrhyming tristich (for example Drobne! Drobne!, Robak solipsyzmu, Wskazówki dla zbieraczy szyszek). In terms of versification, these texts also display great diversity. There are short poems, closed in the form of an aphorism, a distorted event or image:

brzęczą natrętne zdania: świat jest gessty

od nadmiaru ciał, i mówi to dziewczynka

na barowym stołku, a ja jej odpowiadam

nie nie będę grał.

(We śnie, MnI, p. 174)

["bothersome sentences buzzing: the world is thick / with the excess of bodies, said by a little girl / on a barstool, and I tell her / no, I will not play."]

From the other side, there are also expanded verse-poems (for example Drukarenka głodu, Falomino, Letni letarg, Pruski poemat). No regular measure, no rhymes. One of the characteristic features of these poems is being anisometrical. This is the term that applies to non-metric musical pieces, and also to poetry. Pasewicz operates perfectly without a regular metre, the regularity of numbers is not needed here. Numbers hunt for meaning - as Meschonnic correctly says they also hunt for subject, for discourse and for their history ${ }^{183}$. This hunting usually ends up with limitation and restriction, covering the subject, simplifying the rhythm, blurring the uniqueness. The anisometricness of Pasewicz's poetry in particular influences his rhythm, which is based primarily on syntax, on the structure of sentences, but also on metaphors, which the poet is perfectly able to operate. Typography is also another element that contributes to the rhythm of these texts (the spaced-out print emphasising the meaning of particular words, accenting their articulation, their importance in a given text; italics, which often gives the effect of polyphony, writing words in capital letters):

To sobie tak mówię, no masz, historia jest prosta, babcia Wiera w kuchni, moje ciało ma wtedy osiem lat, za osiem lat $\mathrm{z}$ jej ciała nic nie zostanie, $\mathrm{z}$ mojego nie mam pojęcia, zwyczajna historia, nic nie zostaje ze zwyczajnych historii.

Ona zapytała, wtedy, nie teraz, czy jest

Bóg, no, bo wiesz, pyta się dzieci o takie

183 H. Meschonnic, Critique du rythme. Anthropologie historique du langage, Lagrasse 1982, p. 565. 
sprawy. Ja mówię, jest, bo jest jabłko,

bo ja jestem, bo się tak mówi: jest, jest.

(To sobie tak mówisz? Tak, mówię, tak.)

Obierała ziemniaki, a ja razem z nią.

Obierki pac, pac do wiadra, na dworze

skwar, wrzeszczące szpaki na wiśni.

Odłożyła nożyk i wydęła wargi, zrobiła

PUFFF, to się nazywa nic, dodała ciszej.

To sobie mówię, nic nie powiedziała.

powietrze przepłynęło, zawirował kurz.

(No, to masz, MnI, p. 136)

["And so I say to myself, oh my word, the story / is simple, grandma Vera in the kitchen, my / body was eight years old then, in eight years / there will be nothing left of her body, what about mine / no idea, a simple story, / There is nothing left from simple stories. // She asked, then, not now, if / God exists, well, you know, you ask children / about such things. I said, yes, just like an apple exists / just like I do, because this is what you say: exists, exists. // (That is what you say to yourself? Yes, I say, yes.) // She was peeling potatoes, and I was helping. / The peelings flap, flap into the bucket, outside / scorching heat, screaming starlings on a cherry tree / She put the knife aside, pouted, let out / a PUFFF, that is called nothing, she added quietly. // That is what I say to myself, she said nothing, / the air flew by, the dust twirled round."]

Italics indicate yet another important element of the rhythm of these texts, which is counterpoint taken of course from music, but in Pasewicz's texts based on combining within one individual work several different languages, topics, threads, several different registers of expression. Counterpoint works here also at the level of the larger whole of meaning and is perceived in the way of building images that often collide, that are distant and incompatible, yet forming a coherent whole.

In terms of intratypography, the frequent appearance of the ampersand, the "et", is also striking, and I am referring to texts from the cycle Henry Berryman. Pięśni: "Hęry się przeprowadza \& buja / Grzechocką"; „nocą zajmuje go kultura \& wyższe stany / świadomości”; „Ach smrodzik z tą animą \& animusem”; „Wszystko jest polityka \& w złożach ropy trwa”; „patrzy w lustro \& liczy na pamięć”. Just the phonetic writing down of the name "Henry" imitates English here, and the ampersand is added to this which rhythmicises the texts after an English model - this gives a great parody effect. But the ampersand in German Kaufmannsund ("sellers and") or in other words Firmen-Und - here additionally give a double economic significance: like in business names and the iconic abbreviation of the conjunction "and", which introduces the element of saving into the language. 
And there is still the matter of prosody, which in the end is an important element shaping the rhythm of texts. Pasewicz's poems are characterised by a discrete sound structure, which means that it is pushed back to the background. The poet often reaches for various onomatopoeic expressions, but they never constitute an exposed element in any particular way. In some texts, though rather seldomly, various sound combinations appear, but their spot exposure does not play a significant or decisive role in shaping the rhythm of a given text (for example „Na boisku chłopcy grają / w piłkę, krople hormonów harmonizują / z deszczem, co drugi ma zadraśnięcia na udach, / ramionach”; „urządzamy burdy, brudne gary myjemy w nocy” - MnI, p. 53; „skaleczyć kojarzę ze skalą”; „Kałamarnice kłamią i marnieją”; „ocean ocenia” - MnI, p. 64 - all emphasis from the author- A.D.).

Listening as a somatic experience - this is a general formula thanks to which it is possible to bring closer the richness of meanings contained in this polyphonic and many voiced poetry. This is poetry that experiences the world and through itself gives witness to both the world and singular, unique existence. It is not possible to not listen to this poetry because it is only through listening that it is possible to capture this one and only and unique trace of identity that dies in writing to be reborn in reading. 


\section{The sonnet corpus}

The etymology of the word "corpus" used in the title of this chapter is unambiguously associated with the Latin word corpus, meaning 'body'. In linguistics, we speak about the text corpus, meaning the collection of texts that constitute the foundation of linguistic exploration. With regard to literary works, we very often metaphorically speak about the "body of text" or "body of work", "body of verse", "body of poetry" or also "sonnet corpus" (here, in the sense of their collection) $)^{184}$. Of course, we are speaking metaphorically, but this displacement of meaning contains an important message, an important signal that indicates the presence of the physical body in the text. This is not about a simple translation of the body into the word, seeking figurative writing in the poems, as once undertaken, in a very doubtful way, by Robert Faurisson with the famous sonnet Voyelles of Arthur Rimbaud $^{185}$, reading its title anagrammatically (VOYELLES as VOIS-ELLES "see them") and giving the individual lines of the poem iconic features that mimic the shape of the female body (Faurisson made a sexualisation of the text, which met with sharp criticism from experts about Rimbaud's work).

The body of text is a metaphor, which, besides many different meanings, also emphasises the equivalence between the body and the sign (sôma and sema). The sonnet corpus itself is not homogeneous; it is subjected to constant historical changes, just as language changes historically, and changes under the influence of civilisational and cultural changes to the rule of writing literature - the sonnet corpus is alive (yet another metaphor). Today the sonnet body goes through unending transformations: it often loses its classic shape and is deconstructed or demolished so that it can be rebuilt from diffuse and scattered pieces or fragments drawn out from various corners of culture. The most recent sonnet today

184 Compare, for example, D. Anzieu, Le corps de l'oeuvre, Paris 1981; Le corps du texte. Pour une anthropologie des textes de la tradition juive, ed. F. Heymann, D. Storper Perez, Paris 1997; J. Rancière, Le corps du poème, [in:] idem, La chair des mots. Politiques de l'écriture, Paris 1998, pp. 15-84; M.J. Gliserman, Psychoanalysis, Language, and the Body of the Text, Gainesville 1996; A. Finch, The Body of Poetry: essays on women, form, and the poetic self, Ann Arbor 2005.

185 R. Faurisson, A-t-on lu Rimbaud?, Paris 1971. This is about Robert Faurisson, a well-known denier who in 1978 questioned the existence of concentration camps. Eventually he was removed from his professorship at Université Lumière, Lyon. I refer to this example as an extreme abuse and distortion of the meanings contained in literary text. 
is most commonly a work of bricoleur, but remember - as Claude Lévi-Strauss teaches us - the best things take a long time. I want to think of sonnets in such a way as to look at their constant presence in the history of literature, to capture the changes that affect the shape of its modern corpus.

The sonnet is a beautiful, tempting, seductive, yet at the same time difficult and demanding form. This extraordinary form of poetry has spread in a remarkable way in popular literature, and in Polish modern literature it is experiencing a period of extraordinary success. It must be stated unequivocally that none of the poetic forms has been distinguished by such a long period in the history of literature ${ }^{186}$. Where should we search for the causes of this popularity? How can we explain this phenomenon? How can we explain this unlimited proliferation which we see today? Is it only a matter of relationship with tradition? Or perhaps formal beauty and delight in mathematical proportions, as indicated by, among others, Matthew Chiasson and Janine Rogers ${ }^{187}$. The development of this form of poetry, its varied and radical metamorphoses, necessitates a departure from the systemic description, but at the same time demonstrates that its description in relation to the norm is unjust and most often leads nowhere. The sonnet at this time has - but as we will see later, also had in the past - an anamorphic form (transformation, distortion and deformation, like in painting); it is necessary to take a closer look to see the hidden object, which is not fully expressive, homogeneous, but blurred, faded. Still, however, the sonnet remains; it continually appears in literature and for sure will continue to do so.

By observing the transformation of the sonnet from the moment of its appearance up to the present, one can clearly state that no strophic form enjoyed such popularity and underwent such various - sometimes astonishing - transformations. Relying on this form, it would be possible to write the history of general literature or the history of various theories of literature, from classical approaches, through formalism, structuralism, deconstructionism or feminist criticism - there is no literary epoch (and there probably will never be), in which the sonnet would be absent. The description of this form and its thorough analysis should be the subject of extensive study. By necessity, I confine myself here to highlight the most important problem threads.

We will here be occupied by the sonnet and its transformations, especially in the modern era. I said "especially", because speaking of the most recent sonnets,

186 Michael Spiller confirms this opinion. See M. Spiller, The Development of the Sonnet. An Introduction, London-New York 1992, p. 2.

187 M. Chiasson, J. Rogers, Beauty Bare: The Sonnet Form, Geometry and Aesthetics, "Journal of Literature and Science" 2009, vol. 2, No. 1, pp. 48-64. 
we must inevitably refer to literary tradition. Of particular interest to me are all deviations from the generally accepted principles, all deformations, "degeneration" and distortions, "various sonnets" (from "variation" probably, as said by Piotr Śliwiński in the sketch Forma i rozpad about the poetry of Dariusz Suska from the volume $D B 6160221^{188}$ ), and many such examples can easily be given referring to both general literature and modern Polish poetry. A broad discussion of the historical development of the sonnet is contained in the work by Lucylla Pszczołowska and Dorota Urbańska, and mention here should also be made of the work published by Władysław Folkierski in the series "Biblioteka Narodowa” and the thematic number of „Poezja” ${ }^{189}$. In the article by Dorota Urbańska indicated in the footnote, the discussion of the modern sonnet ends on the work by Adam Zagajewski, Powieść historyczna from the volume Płótno (1990) - further to this, the author concentrates primarily on the changes of versification in this form of poetry (this is similar in the essay by L. Pszczołowska). Witold Sadowski, writing about "graphic text" and the possibilities of its development, recently predicted that the sonnet would become "a reorganised genre increasingly recognised on the basis of its notation [...], will also gain a new recipient focused on visual reception" ${ }^{190}$. Apart from the fact that sonnet is not a genre, these predictions have not worked out and probably never will. The sonnet is often recognisable today only when it is clearly indicated by its name, although it is not in the present day the ultimate rule or any formal determinant.

The specifics of the theoretical work on the sonnet are that they focus mostly on formal analyses (there are exceptions to this - I am thinking here in the first place about Ireneusz Opacki's work, placing the emphasis primarily on interpretation). There have been attempts to describe the form in architectural ways: August Wilhelm Schlegel spoke of it as resembling the perfect rectangular shape of a Greek temple, and Folkierski, that

188 P. Śliwiński, Przygody z wolnością. Uwagi o poezji współczesnej, Cracow 2002, p. 197.

189 L. Pszczołowska, Sonet od renesansu do Młodej Polski, [in:] Słowiańska metryka porównawcza. Sonet, ed. L. Pszczołowska, vol. 5, Warsaw 1993; eadem, Wiersz polski. Zarys historyczny, Wrocław 1997; D. Urbańska, Sonet od Młodej Polski do współczesności, [in:] Słowiańska metryka porównawcza. Sonet, ed. L. Pszczołowska, vol. 5, Warsaw 1993; Sonet polski, selection, introduction and explanation by W. Folkierski, Wrocław 1925, BN I, No. 82; „Poezja” 1973, No. 6.

190 W. Sadowski, Wiersz wolny jako tekst graficzny, Cracow 2004, p. 311. 
The sonnet's construction is similar to the overturned cut pyramid, whose broader base would be at the top, so that it would rest on a narrower base, in spite of the strength of its weight. ${ }^{191}$

I am interested in the transformation of the sonnet in connection with the transformation of poetic and cultural consciousness, transformations, which must after all have an impact on the somewhat ossified and less flexible rules of historical poetry, which - as it turns out - are very important in the case of the most modern poetry. I would like to draw attention to the sonnet and its transformations taking place in Polish contemporary poetry, especially in the poetry written in the nineteen nineties and at the beginning of the twenty-first century this period is less well-studied and has to date been poorly described.

Let us briefly recall a short history of the sonnet: it appeared for the first time between the years 1215 and 1233 in Italy, and we assume the creator to be Giacomo da Lentino (or da Lentini) ${ }^{192}$. This kind of poetry was also practised by those contemporary to da Lentini, including the Abbot of Tivoli, Jacopo Mostacci, Piero delle Vigne and Rinaldo d'Aquino. I would also like to mention that the form of two tetrastiches and two tercets described in the definitions is not the first form (the sonnet was influenced by Arabic poetry, old-Provencal poetry and Italian folk poetry, and initially had a layout of four rhymed distiches $a b a b a b a b$ and two rhyming tercets $c d c d c d$ ). The expressive character came into being through Dante and Petrarch (rhymes laid out in tetrastich) and since then its exceptional career has flourished. Jan Kochanowski introduced it into Polish literature (the ditty Do paniej written according to the Italian model), but it is only in the early Baroque that it came to occupy a significant place as an elaborate and at the same time elite form (the most magnificent expression of this is given by Mikołaj Sęp-Szarzyński). In the Baroque era, this strophic form is connected (or also "crosses") with various literary genres (Jan Andrzej Morsztyn - poetic letters, threnody, riddles). Sonnets take on themes which are religious, metaphysical and also erotic. The sonnet practically disappeared in the Age of Enlightenment, although it is worth mentioning here that the famous

191 W. Folkierski, Wstęp, [in:] Sonet polski..., p. XXI.

192 H. Morier, Dictionnaire de poétique et de rhétorique, Paris 1975, p. 960; P. Oppenheimer, The Birth of the Modern Mind: Self, Consciousness, and the Invention of the Sonnet, Oxford 1989, p. 22. There is no full agreement regarding dates, John Fuller (The Sonnet, London 1986) believes that the first sonnet was written by Lentino in 1230 or 1240 , Oppenheimer in turn indicates the period between 1215 and 1230. The difference in the records of the names stems from the fact of changing the name of the town from Lentino to Lentini now - see M. Spiller, The Development of the Sonnet..., p. 14. 
Enlightenment language puritan Jacek Przybylski invented an interesting name for the sonnet, „Zadźwięk” (he wrote a sonnet called Zadźwięk na imieniny Jaśnie Wielmożnego Imci Pana Feliksa z Przybysławic Oraczewskiego...), which was supposed to point to the sound aspect of the sonnet and which did not take off. The sonnet experienced a period of rich blossoming in romanticism, when under the influence of Adam Mickiewicz there came a real explosion of "sonnet mania". The sonnet went through significant transformations here: novelty of subject matter, imaging, vocabulary, specific anti-elitism, lines extended to 13 syllables (in relation to the earlier epochs - 10 and 11 syllables in each line). Great popularity was also enjoyed in the lyricism of the Young Poland movement and the 20-year interwar period. After 1956, it settled permanently in Polish lyricism, even extensive sonnet cycles were created, and I indicate at this point just a few examples: Aleksander Wat's Trzy sonety (from the volume Wiersze from 1957 - a cycle of three works); Stanisław Grochowiak's Sonety białe (cycle of seven poems), Sonety brazowe (cycle of seven works), Sonety szare (cycle of seven works) from the volume Agresty from 1963; Stanisław Swen Czachorowski’s Summa strony sonetu from 1967; Jarosław Marek Rymkiewicz from the volumes Anatomia and Trema regium; Witold Maj from the volume Spór o milczenie (1970) - the sonnet cycle $Z$ medytacyj o baroku siedem sonetów przypisanych Bohdanowi Zadurze (laid out in twelve continuous distich lines and two lines separated); Stanisław Barańczak's six Sonety łamane from the volume Korekta twarzy (Poznan 1968); Witold Wirpsza's Powiew historii po raz pierwszy (cycle of 13 sonnets dividing the remaining texts of the volume and written in italics) from the volume Nowy podręcznik wydajnego zażywania narkotyków (Dariusz Pawelec rightly considers them as a "pastiche of neoclassicism of the sixties"193); Tadeusz Żukowski’s Ksiega listów from 1980 (150 non-rhyming sonnets arranged in the form of letters). A particular phenomenon in this field is Sławomir Rudnicki's poetry, which speaks exclusively through this form, while preserving its classical rules (three substantial volumes of sonnets in the years 2004, 2005 and 2006) and which renews even a form like the crown of sonnets (Salome, Puławy 2004, earlier there was for example the crown of sonnets by Antoni Słonimski Harmonia from 1919). It is impossible to mention all here. Examples could be multiplied to such an extent that a large anthology would emerge from them, much wider than previously published ${ }^{194}$. The anthology would have to embrace both elaborate realisations

193 D. Pawelec, Wirpsza wielokrotnie, Mikołów 2013, p. 190.

194 For example, E. Hamer, English Sonnet: an Anthology, Norwood Editions 1975; R.M. Bender, The Sonnet; a Comprehensive Anthology of British and American Sonnets from the Renaissance to the Present, ed. and introduction R.M. Bender, Ch.L. Squier, New 
of form and deformed versions or texts from the borders of graphomania, which are not characterised by strikingly high artistic or ideological values but exist and cannot be ignored in the whole description of the phenomenon. This is, of course, a job to be done that goes beyond the scope of this text, necessarily from the point of view of specifying selected examples and of the elementary theses that may be further developed.

In the sonnet cycles mentioned here, we can see a very strong connection with tradition: maintaining traditional strophic construction, traditional versification (based mostly on syllabic lines), rhymes according to classical rules, numerous thematic references (especially the Renaissance and Baroque traditions) are preserved. The sonnet is often synonymous with high poetry.

What, however, is actually going on with the sonnet in the latest Polish poetry? First and foremost, it is important that we could make an impressively sized book of these sonnets. Piotr Michałowski, in observing the phenomenon of the extraordinary growth of this poetic form, even spoke about "post-modern sonnet mania"195, and he also wrote about the "changing nature of the sonnet", that it has undergone all possible transformations and revolutions but still manifests its resilience and polymorphism ${ }^{196}$. Speaking of the changes in the sonnet in recent poetry, early on I would like to highlight the impact especially three poets have had on the shape of today's sonnet: Rafał Wojaczek, Bohdan Zadura and Andrzej Sosnowski.

Rafał Wojaczek frequently reached for this strophic form (Fuga, Nasza Syberia, more Piosenki bohaterów, Ojczyzna, Mimikra, Gwalt, Studium). If, however, we were to apply the traditional definition suggested by descriptive poetry to the above-mentioned texts, then it would appear that apart from the strophic layout itself (14 lines in the form: 2 tetrastiches and 2 tercets) and the descriptiveness, which usually covers the entirety of the text, these sonnets reject all other structural determinants belonging to that form. An intriguing matter in Wojaczek's

York 1965; M. Baranowska, Księga sonetów, Cracow 1997; The Making of a Sonnet: a Norton Anthology, ed, E. Hirsch, E. Boland, New York 2008; D. Moncond'huy, Le sonnet. Anthologie, Paris 2005; D. Bromwich, American Sonnets. An Anthology, New York 2007; J.-U. Fechner, Das deutsche Sonett, Munich 1969; F. Kemp, Das europäische Sonett, Göttingen 2006; H. Kirchner, Deutsche Sonette, Stuttgart 1979.

195 P. Michałowski, Ponowoczesna sonetomania?, [in:] Polska proza i poezja po 1989 roku wobec tradycji, ed. A. Główczewski, Toruń 2007, pp. 165-176. Reprint in: Polska genologia. Gatunek w literaturze wspótczesnej, ed. R. Cudak, Warsaw 2009, pp. 176-185.

196 P. Michałowski, Z nowszych dziejów sonetu, [in:] idem, Głosy, formy, światy. Warianty poezji nowoczesnej, Cracow 2008, p. 128. 
sonnets is the arrangement of rhymes, or more precisely, their disappearance. The closed form of the poem is something like a frame subjected to cracking and scattering. The reference to "high culture" is obvious here: it is the sonnet form itself. However, this form does not withstand confrontation with the world presented in the text.

Bohdan Zadura initially cultivated a type of sonnet strongly related to tradition, from which he departed from time to time. Testament to this may be poems such as Chcesz jechać w prawo skręć w lewo, Sonet ułomny and Śmieszny sonet, which are arranged in poetic metapoetic forms and their subject is the sonnet.

Andrzej Sosnowski is a poet for whom metaliterary reflection is very important. Looking at his various writings and comments about poetry, it could be said that he is trying to create a kind of "postmodern poetry". Weaving an interesting reflection about sonnets he wrote, among others, these words:

Perhaps, the secret of 'just so' lies in the $8 / 6$ proportion of a sonnet, in a certain perfection of concept and the 'golden mean'? The form of a sonnet is meant to be universal for the presentation of one real and finished thought. Something is happening, being sketched, taking place, appearing and imposing itself, so I am putting it in order and telling a story, then I'm giving it another thought and drawing a conclusion.

So, in order to write a sonnet, one has to have something to say. Current authors often do without rhymes. But is such a blank verse sonnet the real thing? Perhaps, this question needs to be simply dismissed as uninspiring. What is much more inspiring is the challenging and seemingly timelessly persistent nature of the $8 / 6$ proportion. ${ }^{197}$

One of the most important issues with the sonnet is whether it is a literary genre. Already in this place is the issue of undecidability and ambiguity; the opinions of the researchers in this matter are also very divided today. August Wilhelm Schlegel used the definition "Gattung”; Władysław Folkierski called the sonnet a "literary type"; some scholars define it as a literary genre (for example Lucylla Pszczołowska), as a "poem with a fixed form" (poème à forme fixe), but also a "type" (genre - Henri Morier) ${ }^{198}$; John Fuller calls it verse form ${ }^{199}$; William T. Going, in turn, a significant genre ${ }^{200}$; Janusz Sławiński speaks of it as "canonised strophic

197 A. Sosnowski, Skarb kibica/Sonet. http://poewiki.org/index.php?title=Skarb_kibica/ Sonet (accessed: 14.05.2014).

198 H. Morier, Dictionnaire de poétique et de rhétorique..., p. 960.

199 J. Fuller, The Sonnet..., p. 1.

200 W.T. Going, Scanty Plot of the Ground. Studies in the Victorian Sonnet, Paris 1976, p. 11. 
arrangement of poetic speech" 201 and Anna Kołaczkowska defines it as "a lyrical composition consisting of 14 lines divided into 4 stanzas..."202 - I emphasise here that in Polish research fields only Sławiński consistently avoids the definition "genre". Interestingly, in the latest theoretical approaches the sonnet is treated both as a kind of strophe and as a genre ${ }^{203}$.

It is possible to describe the sonnet according to established norms and rules, but only in some cases. Where now is the norm and what is it based on, since the traditional definition of a sonnet as a set of four strophes, of which the first two are descriptive, and the next two reflective, has no confirmation in the most recent poetry? Such a division today has nothing to do with textual reality, and yet it cannot be said that the sonnet does not exist. It is certain that sonnets are ubiquitous in poetry from the Middle Ages to the present day, albeit with varying intensity (which cannot be said, for example about the villanelle, triolet or pantum, although these forms often appear in recent poetry). Based on detailed analyses of various definitions, as well as analyses of sonnet transformations, I would prefer to speak of the sonnet as a "form of strophe" and not as a literary genre.

In order to talk about sonnet transformations, one must pay attention to any deviations from its determinants. Of course, the deviations do not exclusively refer to contemporary literature. In Polish literature they appeared in the Baroque, and so at a time when the sonnet was passing into a period of immense lushness: Hieronim Morsztyn at that time wrote an unconventional (regarding theme), hedonism-filled work with the title Sonet:

Wina, panien, muzyki, kto chce melancholiki

Rozweselić; to troje wybije ze łba roje.

Więc komu dudy grają, niech mu i nogi drgają.

W taniec skoczyć nie wadzi, tym, co tańcują radzi,

Którzy radzi śpiewają, niechaj mi dolewają.

Frasunki suszą kości, trzeba zalać wnętrzności,

A młodzieńcy z pannami niech się bawią żartami.

Komu kołnierz nie stoi, niechaj żartów nie stroi.

201 J. Sławiński, [entry:] Sonet, [in:] Słownik terminów literackich, ed. M. Głowiński, T. Kostkiewiczowa, A. Okopień-Sławińska, J. Sławiński, Wrocław 1998, pp. 517-518.

202 A. Kołaczkowska, [entry:] Sonet, [in:] Słownik rodzajów i gatunków literackich, ed. G. Gazda, S. Tynecka-Makowska, Cracow 2006, p. 715.

203 See P. Batko, Sonet: gatunek czy strofa. Próba klasyfikacji na tle literatury renesansu i baroku, „Barok” 2007, No. 2, pp. 65-74; A.S. Mastalski, Prototypowość struktury wierszowej jako element kształtowania się semantyki tekstu, [in:] Potencjał wiersza, ed. W. Sadowski, Warsaw 2013, pp. 28-42. 
W strojnych się dziś kochają panny i strojnym dają

Chusteczki wyszywane i pierścionki składane.

Nuż, dzieci, więc w robotę, ten Zosię, ów Dorotę

Porwi w taniec! Regały będą wam wnetki brzmiały.

Przed kim pełne dwie stoją, jedna niech będzie moją.

Bogdajżeś zdrów, sąsiedzie, każdy niech wesół będzie.

["Wine, girls and music, for those who want the melancholics / To cheer up; those three will clear the head. / So whoever the pipes play for, should swing a leg. / It doesn't hurt to dance for those who dance with joy, // Those who are singing with joy, please pour me another one. / I need to drown the sorrows that are eating me up, / Let the young ones amuse themselves with jokes. / Do not let those who can't take a drink make fun of others. // Girls fall for the braw ones and the braw ones they give / embroidered handkerchiefs and fancy rings. / Come on, children, get to work, one with Sophie, the other one with Dorothy // Go on and dance! Regals will soon peal for you. / Ifyou have two short snorts in front of you, make one of them mine. / Cheers to you, let us all be merry?"]

Sebastian Grabowiecki wrote a superb, non-rhyming sonnet (translated from Gabriele Fiamma De te morto, Gesu, nasce la vita), based on playing with two words „żywota/śmierci” [“life/death”]:

\section{CXLIIII}

Z Twej śmierci, Jezu, dochodzim żywota.

Śmierć podejmując dla nas, władzą śmierci

Bierzesz, a z Twej k nam miłości tej śmierci

Moc dawasz, co nas wpuszcza do żywota.

Śmierć, ty godność przechodzisz żywota,

Bo tobą człek ujść może wiecznej śmierci.

Nie ma nic nad cię, święta wdzięczna śmierci,

Droższego ten skarb zmiennego żywota.

Przeto i mnie zbrzydł żywot; pragnąc śmierci,

Gdyż śmierć tylko wwieść może do żywota,

Tak wielka waga w mych zmysłach tej śmierci.

Tak ja mrąc żyję; konam, tak żywota

Pochodzę i tak pożądam tej śmierci,

Że w niej jest rozkosz mojego żywota

["In your death, Jesus, we get through to life. / Undertaking death for us, you take over its / Authority, and through your love to us you grant death / the power that lets us enter life. // Death, you who experiences the dignity of life, / because through you men can escape eternal condemnation. / There is nothing better than you, holy graceful death, / in the treasured fickle life. // Therefore life has grown ugly for me too; longing for death / the value of death is enormous to my senses. // And so I live passing away, die, like going through / Life and so badly long for death / That the pleasure of my life is in it."] 
If we are talking about derogations from the rules of sonnets, it is helpful to understand them as "canonised strophic arrangements". We say "canonised", that is, belonging to the canon, an inviolable exemplar for that which absolutely cannot be omitted. So, perhaps this makes it easier to understand all attempts to violate that which should be inviolable. This is about exceeding the imposed restrictions, going out of the designated area, abolishing censorship, specific transgression. The stakes in play here are language itself, consciousness of the complexity of language, which inevitably changes the status of the speaker, and when poets choose a sonnet, this is often associated with the need to create a discourse that rejects aestheticism. Crossing the norms is varied and goes far into the literary past. We could bring in many interesting examples here, for example Charles Baudelaire wrote "reverse sonnets", with altered strophic organisation (3 344 Bien loin d'ici), and similar can be found in Polish literature, for example Sonet by Stanisław P. Kaczorowski (4 4222 2), Sonetino by Stefan Themerson (4 33 4). Tristan Corbière wrote a cycle of four sonnets: 1. Sonet, 2. Sonet á Sir Bob, 3. Le crapaud, 4. A une demoiselle. The first of these is of particular interest which has the subtitle "together with the correct manner of treatment" (coming from the collection Les amours jaunes, 1873204):

Sonnet (AVEC LA MANIÈRE DE BIEN S'EN SERVIR)

Réglons notre papier et formons bien nos lettres:

Vers filés à la main et d'un pied uniforme,

Emboîtant bien le pas, par quatre en peloton;

Qu'en marquant la césure, un des quatre s'endorme...

Ca peut dormir debout comme soldats de plomb.

Sur le railway du Pinde est la ligne, la forme;

Aux fils du télégraphe: - on en suit quatre, en long;

À chaque pieu, la rime - exemple: chloroforme.

- Chaque vers est un fil, et la rime un jalon.

- Télégramme sacré - 20 mots. - Vite à mon aide...

(Sonnet - c'est un sonnet -) ô Muse d'Archimède!

- La preuve d'un sonnet est par l'addition:

- Je pose 4 et $4=8$ ! Alors je procède,

En posant 3 et 3 ! - Tenons Pégase raide:

„O lyre! ô délire! ô...” - Sonnet - Attention!

204 Quotation after: T. Corbière, Les amours jaunes, ed. E. Aragon, C. Bonnin, Toulouse 1992, p. 76. 
This could indeed be combined with the work by Florian Śmieja Nagrobek so$n e t u$, which is in essence a parody of the form, generally considered to be difficult, but which in fact can be easily stripped of words and rules, but when so treated is uncomfortable and rubs like conventional clothing. It is worth mentioning here the beautiful erotic work by Edmond Haraucourt titled Sonnet point $u^{205}$, whose graphic form becomes a symbolic image enhancing the text's eloquence:

Reviens sur moi je sens ton amour qui se dresse;

Viens. J'ouvre mon désir au tien, mon jeune amant.

Là ... Tiens... Doucement... Va plus doucement... je sens tout au fond ta chair qui me presse.

Rythme ton ardente caresse

Rythme ton ardente caresse

Au gré de mon balancement.

Ô mon âme... Lentement,

Prolongeons l'instant d'ivresse

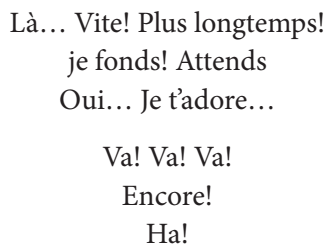

It is a simple matter to indicate other examples of deformation or even a kind of deconstruction, for example the extremely interesting monosyllabic sonnet by the French poet Jules de Rességuier Sur la mort d'une jeune fille (On the death of a certain girl) from $1835^{206}$ :

Fort

Belle

Ele

Dort.

Sort

Frêle!

Quelle

Mort!

205 E. Haraucourt, La Légende des sexes, poèmes hystériques et profanes, Paris 1922, p. 43.

206 J. de Rességuier, Sonnet. Épitaphe, „France littéraire” 1835, vol. 20, p. 174. 
Rose

Close,

$\mathrm{La}$

Brise

L'a

Prise.

This can be put alongside Jerzy Żuławski's work Sonet trójzgłoskowy (based on amphibrachic metre):

Dziewczyno!

wspomnienia

wśród cienia

już giną...

Hej! płyną

marzenia,

cierpienia -

w dal siną!

Daleko

bez końca

się wleką;

już jesień

dla słońca

uniesień.

Interesting sonnet attempts, although not of particular artistic value, are the works of Józef Jankowski included in the volume Sonety wstępujące (od jedno-do piętnastozgłoskowych $)^{207}$. This is a collection of 30 sonnet attempts, poetic exercises - the texts are arranged according to the scheme 446 , with different rhyme layouts, for example abba, baab cdccdd or abba abba ccccdd. The subject of the cycle is actually writing sonnets, playing with the form: „Oto pole mojej sztuki: czternaście ornych zagonów, / A każdy zagon zacny piętnaście kroków tu mierzy..." ["This is the field of my art: fourteen arable strips, / And every strip measures a good fifteen steps ...”].

Here we can also recall the famous Sonet zawichostski by Miron Białoszewski from Kabaretu Kici Koci and present it with the work of the contemporary poet Grzegorz Olszański Sonet po przejśsiach, which is arranged in one extended sentence:

207 J. Jankowski, Sonety wstępujące (od jedno- do pięciozgłoskowych), Warsaw 1934. 


Spośród
dwóch
rodzajów
samobójców
zawsze
wolałem
tych,
którzy
nagrywali
płyty
od tych,
którzy
wydawali
książki.

["Among / two / types / who commit suicide / / always / I preferred / those / who / recorded / albums / to those / / who / published / books"]

Many interesting changes have been brought to the sonnet by modernist "antigrâce": Guillaume Apollinaire wrote in Les colchiques - 15 lines, but shifting one of them, thanks to rhymes, means we get a sonnet (in exactly this poem we should move a line, and in turn in Czesław Miłosz's famous Który skrzywdziłeś to make a full sonnet we are missing a single line, which is, in fact, the meaning of the unsaid line):

Łąka jest jadowita lecz piękna jesienią

Krowy się na niej pasą

I trują zielenią

Zimowi tam rozkwita jego barwa sina

I liliowa twe oczy są jak ta roślina

Fioletowe jak jesień i sine ich cienie

Zabija mnie trujące twych oczu spojrzenie

Ze szkoły powracają dzieci swawolące

Grają na harmonijkach ubrane w opończe

Rwą zimowity które matkami się zdają

Córkami córek kolor powiek twoich mają

Co drżą jak kwiaty drżące kiedy wiatr zawiewa

Pasterz dogląda stada i piosenkę śpiewa

Gdy na zawsze odchodzą krowy rycząc sennie

$\mathrm{Z}$ wielkiej łąki kwitnącej skąpo i jesiennie $\mathrm{e}^{208}$

208 G. Apollinaire, Zimowity, transl. A. Międzyrzecki, [in:], idem, Wybór pism, selection, introduction and notes provided by A. Ważyk, Warsaw 1980, pp. 122-123. 
["The meadow is venomous but beautiful in autumn / The cows graze on it / And are poisoned by green / In winter flourishes there its colour blues / And your lilac eyes are like that plant / Violet as autumn and blue like its shadows / The looks from your poisonous eyes are killing me // School children come back to school / They play harmonicas clad in cloaks / Itching from cold, which mothers seem to be / Daughters' daughters have the colour of your eyelids / They tremble like flowers trembling when the wind blows // The shepherd watches the flock and sings a song / When the cows roam forever, roaring sleepily / From a large meadow blooming sparsely and in autumn"]

Blaise Cendrars transforms the sonnet into a poster Academie medrano, and the whole cycle of sonnets is called Sonnets dénaturés (1916). Here is one example, an extraordinary and extremely successful attempt to distort the traditional form, containing original intratypography, drawing the reader into a game - the necessity of reading certain phrases from the end of each verse $)^{209}$ :

\section{ACADEMIE MEDRANO}

\section{A Conrad Moricand}

Danse avec ta langue, Poète, fais un entrechat

un tour de piste

sur un petit basset

noir ou hanquenée

Mesure les beaux vers mesurés et fixe les formes fixe

que sont LES BELLES LETTRES apprises

Regarde:

Les Affisches se fichent de toi te mordent avec leurs dents en couleur entre les doigts de pied

La fille du directeur a des lumières électriques

Les jongleurs sont aussi les trapézistes xuellirép tuas

teuof ed puoC

aç-emirpxE

Le clown est dans le tonneau malaxé

Passe à la caisse

Il faut que ta langue les soirs où

fasse l'orchestre

Les Billets de faveur sont supprimés.

Novembre 1916

209 B. Cendrars, Poésies complètes, vol. 1, Paris 2001, p. 112. 
Interesting sonnets appear in the work of the group OuLiPo, for example François Le Lionnais in 1973 wrote L'unique sonnet de treize vers et pourquoi:

\section{L'unique sonnet de treize vers et pourquoi}

Les mots nouveaux me donnent de la tablature,

Ils ne figurent pas au Larousse illustré

Et bien souvent je suis quelque peu étonné

Par ceux-ci, dont l'aspect semble contre nature:

Arnalducien, bensilloscope, bergissime,

Blavièrement, braffortomane, duchater,

Lattissoir, lescurophage, queneautiser,

Quevaloïde, schmidtineux, à quoi ça rime?

Mais il est parmi tous un mot imprononçable,

Sous un parler rugueux son sens est délectable,

C'est le mot: oulichnblkrtssfrllnns.

J'eus tort de faire appel à lui pour un sonnet

Car je ne trouve pas de rime à frllnns. ${ }^{210}$

This is why this sonnet is unique, as it is impossible to find the rhyme to match the "frllnns" sounds, as the last words of the poem clearly inform. Another, even more remarkable attempt at mathematical sonnet variation was made by Jean Queval $^{211}$, writing Pięć sonetów:

\begin{tabular}{|c|c|c|c|c|}
\hline ce & coeur pur & Vitrifié & mystérieux & un peut mort \\
\hline ce & richard & Décéda & dans son parc & étoilé \\
\hline ce & faux dur & supprimé & vaniteux & il s'endort \\
\hline ce & vieillard & susurras & que son arc & épuisé \\
\hline ce & n'enfant & réfléchi & dit qu'ailleurs & sur la trame \\
\hline ce & mormon & suçotant & le radar & qui l'avive \\
\hline ce & mediant & reverdi & ce rameur & et sa dame \\
\hline ce & cochon & tatouillant & le nectar & dorigine \\
\hline
\end{tabular}

210 Quotation after: http://unproductivepoetry.wordpress.com/2010/06/30/francois-lelionnais-lunique-sonnet-de-treize-vers-et-pourquoi/ (accessed: 14.09.2014).

211 J. Queval, Cinq sonnets, [in:] Oulipo, La littérature potentielle (Créations, Re-créations, Récréations), Paris 1973, p. 114. 


\begin{tabular}{|c|c|c|c|c|}
\hline ce & noutil & ramol lot & militant & consterné \\
\hline ce & fusil & parpaillot & d'un amant & concerné \\
\hline ce & sabir & connaisseur & d'un gymnase & infernal \\
\hline ce & trépas & amoureux & le voyeur & un marine \\
\hline ce & n'est-cas & fastidieux & sans chaleur & assassine \\
\hline ce & roi Lear & inventeur & d'un sur place & ordinal \\
\hline
\end{tabular}

In principle, this is five sonnets in one, which develop - as the author himself says according to the principles of "settling” and "deposition” („le principe alluvionnaire"), and so like river alluvia. In the volume La littérature potentielle by the OuLiPo group, we also find the cycle Trois sonnets irrationnels by Jacques Bens, which is composed on the basis of the following strophic system: 31415 , which corresponds to five digits of the numerical value $\pi: 3.1415$. In the sonnets these are also the distribution of rhymes: aab c baab cc dccd. The culmination of the OuLiPo group's sonnet attempts is an unusual poetry book by Raymond Queneau Cent mille milliards de poèmes from $1961^{212}$. In this case this is not about deviations, but the possibility of duplicating the simple structure of the corpus of sonnets. The book consists of 10 of the most regular sonnets. The thing about this is that it is an example of combinatorial literature - the lines of each sonnet are printed on separate strips so that the reader can prepare dozens of sonnets out of 10 sonnets, and preparation of this could take about two hundred million years. The simple sonnet structure can be multiplied infinitely - this is exactly what the idea of potential literature is all about. Here we are dealing with livre animé. Closed text corpus becomes infinite and can indefinitely proliferate further texts.

Examples of deviations, deformations, variations in this form could be multiplied, and the sonnets themselves are - paradoxically - inviolable and violable.

The sonnet is also enjoying great success in recent Polish poetry. I will limit myself to just a few examples. Let's start with Miłosz Biedrzycki and the cycle of his two unique sonnets ${ }^{213}$ :

212 R. Queneau, Sto tysięcy miliardów wierszy, transl. J. Gondowicz, Cracow 2008.

213 M. Biedrzycki, Hołd (dwa sonety) - Macie swoich poetów. Liryka polska urodzona po 1960 r. - wypisy, selection and compilation P. Dunin-Wąsowicz, J. Klejnocki, K. Varga, 2nd edition, corrected and expanded, Warsaw 1997, p. 20. 
Kraków 29.01.1991 - hej! co u Was

nowego słychać, bo u mnie nic nowego

nie słychać, ale może u Was słychać

coś nowego, ponieważ jak już wspomniałem

u mnie nie słychać nic nowego; ciekaw

jestem, co takiego nowego słychać u Was,

bo niestety u mnie nic nowego nie słychać

no więc idę posłuchać, co nowego słychać

u moich znajomych, ale, jak się dowiaduję,

u nich niestety też nic nowego nie słychać

i oni mnie pytają, co u mnie nowego słychać

no i niestety rozczarowali się, ponieważ u

mnie nie słychać nic nowego i powiedziałem im,

że u moich znajomych z Buszyna też

["Cracow 29.01.1991 - hey! what's up / new to you, because for me there is nothing new / nothing to hear, but maybe for you there is something to hear / something new because as I mentioned // for me there is nothing new; curious / I am, what is new for you, / because unfortunately, nothing is new / So I'm going to listen to what's new // at my friends, but, as I find out, / for them unfortunately there is also nothing new to be heard / and they ask me what's new for me / / and unfortunately they were disappointed because / for me there is nothing new and I told them / for my friends from Buszyna too"]

\section{II}

nic nowego nie słychać, więc mówię, że u moich znajomych, których wy nie znacie niestety, u nich też nic nowego nie słychać, bo chodzi o to, by coś coś nowego było słychać, a nie starego. więc co słychać nowego napiszcie, bo u mnie nic nowego, u nich też nic nowego i u tamtych też nic nowego, a tamci także mówią, że nic nowego więc proszę uratujcie nas wszystkich powiedzcie, że jednak coś nowego

u Was słychać, z poważaniem Mirek Gonzales Flokiewicz, Kraków ul. Krowoderska 57/4a 
["nothing new to hear, so I say, that my friends, whom you do not / know unfortunately, they also have nothing new / nothing to hear, because it's about something // Something new was heard, not old. / so write what is new, because / there is nothing new for me, for them also nothing // And they also say that nothing new / so please save us all / Say there is something new // to hear with you, sincerely / Mirek Gonzales Flokiewicz, / Cracow ul. Krowoderska 57/4a"]

We can also add in this place two sonnets by Darek Foks ${ }^{214}$ - the parodistic element is already present in the title:

Sonet drogi

Niedopałek Europy, Norymberga świtu.

Zaraz powinna być jakaś stacja benzynowa.

Laura Palmer wykrwawiła mi się

na tylnym siedzeniu. Nie zabiłem jej,

ale ją wiozę. Niczego o niej nie ma

w komputerach celników. Państwo nie żyje,

amfetamina drożeje. Niewiele widzę

w zachwyceniu. Bawarskie wioski

i wieśniacy Francji. Hiszpan przemawia

do mnie językiem Hiszpana. Niczego

o nim nie ma w moim notatniku. Notatnik

zostawiłem w kraju. W Lizbonie

agentka Scully zrobi mi laskę stulecia.

Tymczasem Bułgarki nie dają za wygraną.

[“Dear Sonnet // European Nights, Nuremberg sunrise. / There should be a petrol station soon. / Laura Palmer bled away / in the back seat. I did not kill her, // but I carry her. There is nothing about her / in the customs officers' computers. The state is dead, / Amphetamines are getting more expensive. I do not see much / in delight. Bavarian villages // and the peasants of France. The Spaniard speaks / to me in the language of a Spaniard. Nothing / do I have about him in my notebook. Notebook // I left in the country. In Lisbon / Agent Scully will give me the blowjob of the century. / Meanwhile, Bulgarians do not give up."]

214 Poem from the volume Sonet drogi from 2000. The second of these is given the following commentary by the author: "One day I noticed that the television had a secret plan, of which I slowly became a victim. I tried to describe it as precisely as I could in "Second Sonata". By the way, once again it turned out again that television is stronger than the cinema network". 


\section{Sonet drugi}

Krwawa niedziela, krwawy poniedziałek.

$\mathrm{W}$ niedzielę nie miałem nic

do roboty, więc trafiłem na kawałek

Popiołu i diamentu. W poniedziałek

trafiłem na kawałek Popiołu i diamentu

bo miałem tyle roboty, że musiałem

na coś trafić. Za każdym razem na ten sam

kawałek. Krwawa niedziela, krwawy

poniedziałek. Żołnierz pyta żołnierza,

ile ma lat, a kiedy żołnierz odpowiada

żołnierzowi, że sto, żołnierz wali żołnierza

w dziób, pyta jeszcze raz i słyszy, że sto jeden.

W tym roku był to właśnie ten kawałek.

Krwawa niedziela, krwawy poniedziałek.

["Second sonnet // Bloody Sunday, bloody Monday / On Sunday I had nothing / to do, so I found a piece / of ash and diamond. On Monday // I found a piece of ash and diamond / because I had so much work I had to / find something. Every time the same / piece. Bloody Sunday, bloody // Monday. A soldier asks a soldier / how old he is, and when the soldier answers / the soldier, that he is a hundred, the soldier hits the soldier // On the nose, and asks again, and hears, a hundred and one / In this year there was exactly this piece / Bloody Sunday, bloody Monday"]

\section{And also a sonnet by Mariusz Grzebalski ${ }^{215}$ :}

\section{Wiersz}

który miał być sonetem, nie chce być sonetem.

W maju na trzy tygodnie traci mowę.

Śni, że jest pantumem.

Z letargu budzi go kosmiczna sceneria cementowni i śmiecie walające się wokół bazy TIR-ów w Mulhouse zupełnie jak w Polsce.

Nową interpunkcję łapie w gospodzie

Zum Hirschen pod Salzburgiem.

Ale czym jest, staje się w Olejnicy

niedaleko Przemętu - w fińskim domku,

nad jeziorem, które zarasta rzęsą.

Dziewczynka mówi: Polnik kolny - już to ma!

Najszybszy we wsi.

215 Both works are to be found in the volume Stynne i świetne, Wrocław 2004. 
["A Poem // which was supposed to be a sonnet, does not want to be a sonnet. / In May loses speech for three weeks. I I dream of being a pantum. / A cosmic scene wakes him from lethargy / the cement plant and rubbish crashing / around the TIR's Mulhouse base - / just like in Poland. / New punctuation caught in the inn / Zum Hirschen near Salzburg. / But what is it, it becomes in Olejnica / near Przemęt - in a Finnish cottage, / By the lake, which overgrows the lashes. / The girl says: Polnik kolny - already has it! I The fastest in the village."]

And from the same author another sonnet with an atypical strophic structure (4 343 ) coming from the same volume:

Okoliczności łagodzace

Tirówka wypluta na pobocze jak pestka słonecznika na brzeg stawu, w którym rezydują łabędzie.

O łabędziach nie można powiedzieć „zaludniają”.

Wiatr błądzi w tlenionych włosach, niesie liść,

popycha kasztan, kiedy jej cień ochoczo kładzie się

w trawie. Tam gdzie byłem i gdzie mnie teraz

nie ma - słońce. Wysoko, wysoko! I jakże mocno.

Oni też byli mocni, ale skończyło się, gdy wybiła

północ. Hejnał pognał w mrok jak dzik na wieść

o młodych kartoflach. Wyjechali w południe,

rano nie sposób było ich dobudzić. Tutaj zaczyna się

inna historia. Znaleźliśmy portfel. Nic w nim nie było.

Mówiłem nie na temat, wzruszałem się i mało nie uderzyłem

w płacz. Na szczęście przyszedł kelner z rachunkiem.

["Attenuating circumstances // A TIR person spat on the hard shoulder like a sunflower seed / to the edge of the pond where the swans reside. / We cannot say "populate" about swans / The wind wanders in the airy hair, carries a leaf, // pushes the chestnut when her shadow eagerly lays down / in the grass. Where I was and where I am now / not - the sun. High, high! And how hard. // They were strong too, but it ended when it hit / midnight. The hejnal rushed into the darkness like a wild boar with a message / about young potatoes. They left at noon, / In the morning there was no way to wake them up. Here begins // another history. We found a wallet. Nothing in it. / I spoke off of topic, I was moved and was almost hit / by crying. Fortunately came the waiter with the bill."]

Miłosz Biedrzycki wrote a sonnet titled 14 with an unusual strophic structure (3 3332 ) - literary history provides many such examples of breaking sonnet form; it is a verse without a beginning and without an end (ellipsis), a poetic attempt to transform the visual experience from film recordings: 
...potrzaskany krajobraz - jakby był nakręcony gdzie indziej

i na bluboksie wkluczowany w puste miejsce za oknem,

niedokładnie.

dalekie syreny wyją, autoalarmy ćwierkaniem żegnają

odchodzących panów. kciuk upału wyciska powietrze

spomiędzy nieba i samochodowych dachów w korku.

liście robinii w tym świetle znienacka odwracają się

srebrną stroną i wyskakują w górę jako ryby.

kanciasty wirujący, spadający, zbliżający się kształt

trzeba by zeskanować osobno i zrobić szparowanie

klatka po klatce. dopóki w trzydziestej godzinie montażu

ktoś nie zauważy, że najważniejsza twarz,

migająca tylko przez chwilę, ale najważniejsza

ma źrenice pokryte napisami w odwrotną stronę...

["...shattered landscape - as if filmed somewhere else / and on the bluebox inserted in an empty space outside the window, / not exactly. // distant sirens scream, autoalarms chirp farewell / to dying masters. thumb of heat squeezes the air / between the sky and the car roofs in the traffic jam. // robinia leaves suddenly turn away in this light / silver side and pop up like fish. / angular spinning, falling, approaching a form // it is necessary to scan each separately and make gaps / frame by frame. only just thirty hours of montage / Someone will not notice that the most important face, // flashing only for a moment, but most importantly / has pupils covered with inscriptions in the reverse side ..."]

In 2010 Robert Król published a poetry collection called Czternastki consisting of 60 "sonnet-commandments" in the form 473 . This list could easily be expanded by adding sonnets by Paweł Lekszycki, Marta Podgórnik, Andrzej Sosnowski, Jacek Gutorow, Jacek Dehnel, Stanisław Chyczyński, Julia Fiedorczuk, Tomasz Różycki, Dariusz Sośnicki and many, many others.

Rhyme is also disappearing in contemporary sonnets. This is not about preserving rhyming patterns - rhyme is disappearing. In modern poetry it becomes anachronistic to the point where reading rhyming verse today, we wonder sometimes how this is even possible. The newest poetry - more sensitive to colloquial language and taking full advantage of it - more frequently is "from rhyme" (as in the well-known and excellent ballad by Miron Białoszewski dispelling all illusions associated with the possibility of taking total control of language. The fluidity that regular metre gives a poem also disappears, but the number of lines remain (and this is inviolable!) - there must be 14. Piotr Michałowski, discussing various issues related to the postmodern sonnet says that this is a "quasi-genre", and speaks also of "graphic mimeticism" (in reference to the work by Maciej Niemec Zmierzch) 
and about "sonetoid work" 216 . The dismemberment of the classic sonnet form is nothing new, as I have tried to show through many of the examples given earlier. There is no reason to desperately cling to some pattern. We should rather look at the question of the popularity of this form and what determines its deformation. There are certain perceptible regularities that can be verified in many contemporary sonnet texts: the newest sonnet is moving towards short poetic forms, into epigrams or even ditties; 14 lines; ephemeral, often with a humurous, bitter smile, some general wisdom and at the same time a sharp, expressive punchline. This is why the sonnet responds perfectly to the tendency of economy of speech and language (acronyms, matter of factness, economy) - the sonnet text is short, like a song on the radio, a video clip from the television - a short story, a little tale, just a fragment, which is to be thought-provoking. The phenomenon of the sonnet in the latest poetry would not be so much as indicated by Andrzej Sosnowski in "proportions of $8 / 6$ " (Folkierski indicated that between 8 and 6 there is a "rhythmical pause" to be found which introduces a mental and emotional boundary, while AndréGendre spoke of the "pythagorean beauty of the sonnet"217, also Julian Przyboś, who spoke of the "just right" sonnet, "not too tight, not too loose", and pointed to the relationship of its rhythm to the rhythm of breathing and the heartbeat ${ }^{218}$ ), as in the "magic" number 14, which together with very strongly exposed punchline decide on this "just rightness", as Sosnowski said, of the poetic statement. The matter is based on numbers, and Sosnowski's opinion is confirmed by Erik Greber, who recognises the sonnet as a genre based on the knitting together of words and combination ${ }^{219}$. This "right now" may be associated with a kind of economy of speech, not too long, not to talk excessively, speak shortly, sparingly and accurately, like in a short-lasting song. Speaking in order to be heard in this modern, hurrying culture, which is becoming more and more of a monologue, it is not possible to ask the listener to receive an overly elaborate message. Strophic variations within this "magic fourteen" do not come down to simple play with convention, but they often have a metaliterary dimension belonging to contemporary literature in general. This is how it is in Grzebalski's Wiersz, an example of a sonnet from which only 14 lines are left and the name of the sonnet which does not want to be written is mentioned

216 P. Michałowski, Z nowszych dziejów sonetu..., pp. 121-124.

217 A. Gendre, Evolution du sonet français, Paris 1996, p. 12.

218 J. Przyboś, Zapiski bez daty, Warsaw 1970, p. 83.

219 E. Greber, Textile Text - Poetolgische Metaphorik und Literaturtheorie. Studien zur Tradition des Wortflechtens und der Kombinatorik, Köln 2002. Please see chapter Das Sonett als Gattung des Wortflechtens (Entrebescar los motz/Pletenie sloves) und der Kombinatorik, pp. 554-626. 
in the text. It is seemingly a lightweight, unencumbered text, but is in fact a deep metapoetic work trying to find the answer to the question of what poetry is. The form does not want to take shape here, remains suspended, says simultaneously "yes" and "no", yearns for the traditional order and at the same time is aware that this order cannot be found. This is one of the more interesting examples of sonnets about sonnets, but not just, for the poet also speaks about poetic language, about its secret, the mystery of the poem. A girl who says the word „Polnik kolny” is not just committing a mistake typical for a child, but is also creating an anagram of the phrase „konik polny”, which is just not a simple name for a thing because it constitutes an allusion to the poem by Velimir Khlebnikov titled Konik polny, analysed once by Roman Jakobson, who was fascinated with the anagrams of Ferdinand de Saussure ${ }^{220}$, about which Grzebalski must surely have known.

An important feature of contemporary sonnets is their self-reflective nature, also autothematism, which in no way resembles the parnasist delight over the sonnet form spoken of by Kazimierz Przerwa-Tetmajer in O sonecie.

Sonnet in the newest poetry is a "verse form", which has only one determinant: 14 lines, without any deviation (all formal exceptions apply only to systems within the structure of strophes and rhymes, but the principle of 14 lines remains ${ }^{221}$. The sonnet becomes a 14-line form that cannot be changed, only varied.

Despite the constraints imposed on construction, this form is inexhaustible. On the one hand, it contains all the baggage of literary tradition (especially in those works that are defined by the name "sonnet" - as this name opens the rich intertextual space for the reader). However, the modern sonnet does not aim at convention at all (it is pushed to a distant plan) or towards "high poetry". The

220 R. Jakobson, Podświadome modelowanie werbalne w poezji, transl. A. Tanalska, [in:] idem, W poszukiwaniu istoty języka, vol. 2, Warsaw 1989, pp. 142-156.

221 Also, this principle is not entirely secure, indeed where should we start with the poetic prose of Maria Pawlikowska-Jasnorzewska from Szkicownik poetycki (1939) - a short, given the number 38, poetic prose, condensed and compact in epigrammatic form, in which the name "sonnet" exclusively appears (the poetess repeatedly reached to the classical sonnet form, sometimes slightly changing strophic layout, for example, Salamandry or in translation from Anna de Noailles Dnie, minęłyście - with the form $4442)$ :

Sonet wiosenny, stworzony już jest raz na zawsze pierwszą zielenią brzóz, pierwszą mgłą kwietniowej ektoplazmy, wijącej się wkoło gałęzi pierwszym grzanym deszczem, który szeptem deklamuje o świcie, w cichej przechadzce swej wkoło po ogrodzie - i pierwszym dźwięknięciem ptaka kowalika, kującego w jakiś meta-metal. 
sonnet has long since ceased to be a form to prove a poet's creative craft. The departure from convention is unambiguously linked with the need for a very clear identification of subjectivity, uniqueness.

One of the most frequently repeated themes in the latest sonnets, though not always explicitly expressed in texts, is a kind of ennoui - and so weariness of form, a certain variety of melancholia artificialis, hidden beneath the surface of the text and often perceivable in the unconscious text.

Regardless of all the formal transformations the sonnet has undergone, is undergoing and will undergo, it is possible today to repeat the words that John Fuller wrote at the end of his book about sonnets: "The sonnet is alive and possible"222.

Józef Wittlin in the well-known essay Orfeusz w piekle dwudziestego wieku wrote about genres which by their very name refer to sound (ode, hymn, elegy, rapsody, psalm, canzona, sonnet) and he recognised the disappearance of sound and voice as a specific of twentieth-century poetry (or rather their subordination to the rhythm of typewriter beats). At the end of the past and at the beginning of the twenty-first century it is possible to observe the reverse phenomenon: poetry returns to sound and voice (this is evidenced by the melorecitation of Marcin Swietlicki, the fact that in poetry web portals one can listen to recitals, and the poets themselves are eager to publish the recordings of their poems). The contemporary sonnet is supposed to sound (we should remember that the etymological meaning of the word comes from the Italian sonetto, and from the Latin sonus meaning 'tone' or 'sound' and also 'song') and it sounds, which is decided by rhythm. David Fuller, speaking of sonnets, states unequivocally:

Reading aloud is one of the best ways of fully inhabiting the experience of a poem - participating in its feelings, taking pleasure in its words. [...] - sound in poetry is intrinsic to meaning. Meaning in poetry is never wholly independent of sound. ${ }^{223}$

In the newest sonnets (and also in the latest poetry), the numerical line more and more disappears, rhyme disappears, but rhythm remains. Stanisław Balbus, writing once about Czesław Miłosz's ${ }^{224}$ verses drew attention to the fact that in his poetry "disposable systems" very often appear. Balbus's remarks can be applied to today's poetry in general, in the most recent poetry texts we are dealing

222 J. Fuller, The Sonnet..., p. 49.

223 D. Fuller, The Life in the sonnets, London-New York 2011, pp. 75 and 76, emphasis Adam Dziadek.

224 S. Balbus, „Pierwszy ruch jest śpiewanie” (O wierszu Miłosza - rozpoznanie wstępne), [in:] Poznawanie Miłosza. Studia i szkice o twórczości poety, ed. J. Kwiatkowskiego, Cracow 1985, pp. 461-521. 
more and more with such "one-use systems" that arise for each individual unique poem, in which without doubt it is exactly rhythm that distinguishes the identity of the creators.

It is especially important that sonnets appear not just in literature. Let us go back once more to etymology, which points to "tone" and "sound", and also to "song". It is worth recalling that in Polish literature one of the most interesting attempts at directly linking sonnets to music is Sonety instrumentalne composed in an original way by Witold Hulewicz ${ }^{225}$. The volume does not contain a table of contents, but a "register" - like a music register. Other sonnets describe the orchestra, selected instruments (flute, oboe and horn, clarinet, bassoon, trumpet, horn and several others), as well as families (strings, wind, brass, percussion), there is Baton (with a separate sonnet devoted to it) and there are Singles (Piano, Organ, Human Voice). Further parts of the cycle are Choir, Also instruments (Barrel organ, Carillon, Clock, Oven, Samovar, Electric Bell, Saw and a few other so to say, "day-to-day instruments", which in a special way also form music: Locomotive, Thresher, Mill, Forge and finally Remington). The next cycle in the volume is Oblicza - sonnets dedicated to outstanding composers: Bach, Beethoven (nie-sonet) - the only exceptions to the sonnet form are, Schubert, Chopin, Debussy. The last volume of the cycle, titled Definicje, is devoted to various musical concepts (Nuty, Jazz, Synkopa, Pauza, Fermata, and finishes with Cisza po muzyce, which significantly closes this literary-musical volume of sonnets). It is worth quoting at least one of these pieces, a very successful attempt to describe jazz music:

Jazz

Za woalami ostro wiercą pstre perfumy.

Rżnięte smyczki, trzaski, szklanki, kwiki, szumy.

I przegięte nagie plecy, chuć zadumy.

Łypią białka. Mrużą lampy. Mdleją tłumy.

Z synkop dziury rosną w zmysłach i w pamięci.

Ramion wzdrygi. Chwiejność kolan. Uśmiech nęci.

Wszyscy w rytmach ciemnoskórych jak zaklęci,

gdy saksofon, smętny wyjec, młyńca kręci.

Przerażone, rozgromione nuty, tony,

czarty, kwarty, seksty, tercje, kwinty, nony

obłąkane zbiegły się w ten punkt szalony,

225 W. Hulewicz, Sonety instrumentalne, Warsaw 1928. 
gdzie pałeczki flagelanckie takty biją,

nogi skaczą, skrzypce dziką trąbą wiją.

Carny Sabat z piękną kolją: żywą żmiją...

["Jazz // Behind the veils, they drill mottled perfume. / Slaughtered strings, crashes, glasses, whispers, noise. / And a bent naked back, blowing reverie. / Squinting proteins. Squeezing lamps. Swooning crowds. // From syncopation holes grow in the senses and in memory. / Shoulders flutter. Knocking knees. Smile entices. / Everyone in dark rhythms like cursed, / When the saxophone, the melancholic wailer, turns the mill. // Frightened, broken notes, tones, / devils, fourths, sixths, thirds, fifths, ninths / the delirious rushed to this crazy point, // where the flagellant sticks beat bars / feet jump, violin wails with a wild trumpeting / Black Sabbath with a beautiful necklace: a living viper ..."]

In the case of the sonnet, musical correspondence also extends to jazz and classical music. Many sonnet compositions were left behind by Duke Ellington, for example Sonnet for Caesar, Sonnet to Hank Cinq, Sonnet in Search of a Moor, Sonnet for Sister Kate. Around the year 1810 Karol Lipiński composed Sonet na orkiestre [Sonnet for Orchestra], in Stanisław Moniuszki's compositional output there are Sonety krymskie [Crimean Sonnet], cantata for solo voices and mixed choir accompanied by orchestra from 1867, in 1956 Tadeusz Baird brought out Four Love Sonnets to Words by William Shakespeare, in 2000 Maciej Piszek together with Jacek Laszczkowski recorded Sonety Szekspira [Shakespeare's Sonnets] for male soprano and piano, and in the same year Pawel Mykietyn's Shakesepeare's Sonnets came out. In contemporary classical music the sonnet is often a type of song: Piotr Moss Sonnet pour Astrée na baryton i fortepian, Piotr Paweł Koprowski Sonet for Laura na flet i fortepian, Piotr Radko Sonety na klawesyn i instrumenty smyczkowe, Lidia Zielińska Sonet o Tatrach dla 4 muzyków - I give here only a few of the dozens of possible examples. The French composer Patrick composed Trois chansons érotiques, amongst which is Sonnet pointu pour voix et piano from 1997 to the sonnet quoted above by Edmond Haraucourt, in 1983 Adriana Hölszky composed Sonnet für Stimme und Zwei Gitarren (Sonnet for Voice and two Guitars) to words by Shakespeare. Examples, too, in this case, could be multiplied. It is also worth recalling that the sonnet entered pop culture: musicians singing Shakespeare's sonnets, for example Sting or Stanisław Sojka, and Jacek Karczmarski writing and composing Pięć sonetów o umieraniu komunizmu.

Naming the sonnet's canonised strophic system with a strictly defined number of lines and strophes, of which the first two are descriptive tetrastiches, and the next two are reflective tercets, as well as certain rhyme systems, from the point of view of modern sonnet texts, is quite incompatible with reality. Fewer sonnets are being written today with a regular structure of strophes and rhymes 
than sonnets to which these principles are completely irrelevant and to which the traditional rules of poetics are totally helpless. Helplessness also arises from the fact that description is limited to literature alone, and in this case it should not be. The sonnet was and is present in jazz, just as it is in classical music or in pop. There are no rationally explainable reasons why this plurality of contexts is, as a rule, completely ignored in synchronic or diachronic literary description. The phenomenon of the sonnet is not limited to just one field, to one area of culture, and describing it from a single point of view flattens the phenomenon and ultimately leads to the one dimensionalilty of something that itself today (and not only, as I show after a thorough view of the subject) has a polymorphic nature. This is deaf writing about something which in its name itself contains the word "sound". The description of sonnets given here is of great importance, so that the space of literary viewing of the text widens and increasingly tends towards the prospect of mutual interpenetration of the arts. The sonnet corpus is not limited just to literary text, because it opens up to other artistic practices, to other - as it were - practices of the body, to other sensory experiences. It is worth noticing that this fact is noted not just through comparative literature but also by historical poetry and versology, which will no longer be able to avoid these facts and will be forced to seek innovative solutions combining the rich tradition of research with the literary and theoretical present ${ }^{226}$.

\section{Supplement}

Against the background of all the deviations from classical form that appeared in Polish poetry (but also in world poetry) in the twentieth century, there is

226 Certain possibilities of further research in this field also open up the concept of intermediality created in 1983 on the basis of the concept of intertextuality by Aage Hansen-Löwe (A. Hansen-Löwe, Intermedialität und Intertextualität: Probleme der Korrelation von Wort- und Bildkunst: Am Beispiel der russischen Moderne, [in:] Dialog der Texte: Hamburger Kolloquium zur Intertextualität, „Wiener Slawistischer Almanach”, ed. W. Schmid, W.-D. Stempel, Vienna 1983, vol. 11, pp. 291-360), and later developed by Werner Wolf, Irina Rajewska, and in Poland first and foremost by Andrzej Hejmej (W. Wolf, Intermediality Revisited. Reflections on Word and Music Relation in the Context of a General Typology of Intermediality, [in:] Word and Music Studies. Essays in Honour of Steven Paul Scher and on Cultural Identity and the Musical Stage, ed. S.M. Lodato, S. Asbden, W. Bernhart. Amsterdam-New York 2002, pp. 13-34; I.O. Rajewsky, Intermedialität, Tübingen-Basel 2002; A. Hejmej, Komparatystyka. Studia literackie - studia kulturowe, Cracow 2013). This is a separate issue that requires separate studies and new theoretical approaches. 
an exception, the "total sonnets" by Zbigniew Sajnóg. This is a never-beforepublished collection of texts titled Reisepsychose sonety totalne, which requires a brief discussion just in the form of a supplement ${ }^{227}$. Seemingly it is just an excess, an expression of rebellion of the young generation, but this revolt has incredible power, which left a permanent, indelible mark on the corpus of texts. This is a collection intentionally unpublished because the sonnets therein (or more exactly "sontots” - this is a new name that uniquely distinguishes them from sonnets) were intended to be presented, to be staged, to be "realised", and every time differently, each time with different scenography (in the years 1987-1988 there were three such "realisations" - in Gdańsk, in Łódź and in Warsaw). This is a collection of texts that goes beyond any possible form of negation of the sonnet form - in this collection the sonnet as a classical type of strophe becomes not only an object of total destruction, but also a tool that is intended to serve the artistic purpose of "Western culture boasting of its magnificence" - as the author states in closing the collection Sontot 23, being at the same time, something in the nature of an interview with himself (Quasiwywiadotot), signalling the main assumptions of the whole collection of poetry. This, which most effectively compromises the great achievements of Western poetry, is indeed the sonnet "That's what I think," writes Sajnóg, "and I fucked up the change into buckets of despair and delight". It would be difficult to find so radical a position that goes far beyond all transgressions made by the futuristic or avant-garde movements in Polish poetry (but also, as was said earlier, world). The declarative matter has nothing to do with the avant-garde, because, as the author himself explains, Sonety totalne were created in "times of permanent end"; hence, artists associated with totart are not the creators of the avant-garde, but the rearguard ("We are the rearguard of national culture, we watch out so that no-one should kick it up the arse"). The Sontots are therefore measured in the corpus of the classical sonnet, the most representative form of the literary canon. The point is to wreck this form, it is to be destruction of a "special kind", as the author says, "Destructive not by deconstruction, but by over-organisation, hybridisation". The matter of over-organisation and hybridisation does not raise much doubt, but it must be noted that deconstruction (at least this philosophical - as far as the author is concerned) does not destroy - deconstruction is not destruction but is simply dismantling and displacement.

227 I would like to thank Paweł Konnak (Koñjo) for making the typed manuscript of this extraordinnary text available to me. I would also like to thank Piotr Śliwiński and Marcin Sendecki for their help. All quotations in my text come from this typed manuscript. 
The whole collection is composed of 23 texts, each one of which constitutes an original element of the destruction of classical form - in this respect we are dealing with evident formal profusion (the author himself even speaks of "protoprofusinism"). So there are texts here whose forms are compliant with classical forms from the point of view of strophic structure (maintaining the division of 4433 ), but there are also those that are arranged in a continuous 14-line notation, there is a large sontot written in prose (Rozlegly sontotalny kolaz monolityczny), there is also "irregular sontocytat" with the layout 4432 , and also „półsontoty" ["half sontots"] (4 3) and „ćwierćsontot” ["quarter sontot”] (4 lines), and alongside these there are also „sontotercyna”, „postsontot” and „asontot”. Each sontot is marked with Arabic numerals in order from 1 to 23 and additionally a subtitle, in some cases extremely important, as it delineates the manner of destruction (partly by the ironic, parodistic use of descriptive poetic concepts): Praktyczny sontot nieregularny nauki o końcu, Rozległy sontotalny kolaż monolityczny, Sontocytat nieregularny, $W$ trzech czwartych monolityczny ćwierćsontot w sprawie katastrof, Praktyczny sontot nieregularny nauki o końcu, Sontotercyna sypialna, Sontot supermonolityczny o oddaniu się w ręce władz w obliczu samozagrożenia ["Practical irregular sontot of the science about the end, Extensive sontotal monolithic collage, irregular Sontocitation, In three fourths monolithic quartersontot on the matter of disasters, Practical irregular sontot of the science about the end, Sontotercet sleeper, Sontot supermonolithic about putting oneself in the hands of power in the face of self-threat"] which is worth mentioning here:

Sontot 18 
And still another example, illustrating this destructive practice, as mentioned earlier:

Sontot 21 Internacjonalnie o pokoju na świecie postsontotem

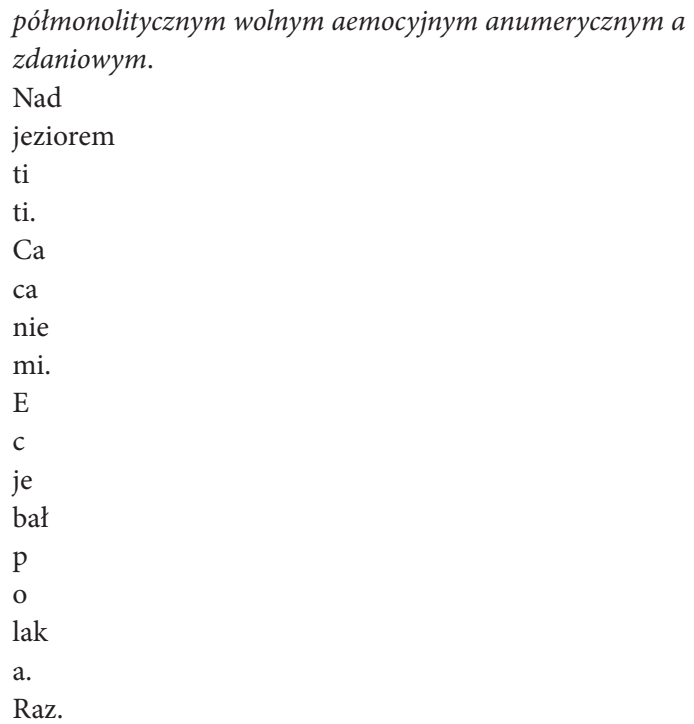

In the rhythmic formation of texts, several different elements play an important role. In all certainty intratypography, the notation of the text on the page - the poet himself stresses the need to "unlock the space between the cosmos of graphics and articulation," speaks about the "detachment of graphical characters from articulation". They are composed on the page in such a way that the reader is set on "visual aesthetic contemplation". In short, it is necessary to look at these texts, to see them, to recognise their unusual notation, which forms the rhythm which is completely unknown to the reader (majuscules at the beginning of every 'strophe', dots at the end of every 'strophe', frequently in the middle of a sentence). For the rhythmic formation of particular texts, the phonosphere is also important, starting with the name of the poet, which is distorted by the anagram on the title page: sspiknieff mesjago (almost all the voiced consonant phones have been removed from the name (and - in agreement with psychoanalytical terminology could indicate castration), and in turn the surname "Sajnóg“, in accordance with the rules of anagrammatic reading, it is possible to read this in the word "mesjago", where it becomes a word mannequin („sjag”). Of course, in this adopted surname it is possible to hear the name "Mesjasz" - Sajnóg, which transforms into the Messiah, takes on the significant name of the Other, which in the context of his later biography will be of great significance. 
Sontots are without rhyme, in some fragments of rhymes appear, and their arrangement and selection is saturated with parodistic element:

Sontot $12 \dot{Z} y$ wot ponury i tortury a twórczości góry
Alem się $\mathrm{r}$
ozdarł na
szczyt kali
opy gdzi.
E dotąd ni
komu z obc
iętymi sto
py nie da.
Nie było gu
Zowate rył
o rozedrz.
Eć na co $t$
am było ej
było było

Let us also add to this the previous one in which the rhyme in the first verse is reminiscent of texts by Fr. Baka or Miron Białoszewski:

Sontot 3 Socjolgiczno filozoficzny sontot monolityczny.

Łupież grabież czy choroba stara baba ma zajoba ani myśli o pobyci

e w całodobowej klinice leku nie zastosujesz zabić gorzej się zeps

uje niby orytozalążkowa a okrakiem i drapakiem się tam czochra ła

py ma niczem wiosła nie udusi to ocali ale na pewno osmali upa łu

pał aż odpadło choćbym zobaczył nie zgadnę czy co wąznego azali mn

ie kto z wiatrami osmarczył tylko czego nie określę idzie gruda ja

k po maśle a że wciągasz szyję nie zadusi to przymusi a w domu cz

y na ulicy nie pomogą ratownicy a to wszystko że się na jedne $z$ ta

ką współrzędne skazanym jest się a to czy lizie czy leży jednako ś

mierdzi i po równo z każdej otwory i jeszcze spod pachy i nogi i r

ajstopy i buty i gacie a jeszcze i sra i żre i za wybrane uznaje $s$

ię to i inne zeżre a przed tym ucapi bo jeszcze za mądre uchodzi a

i se uwarzy bo to kulture tworzy i dobrze ma się spierdalaj gnoju

a poetm będzie lepiej albo gorzyj a po filozofii śpi dupa dupa ch.

Where does the violation of the convention come from, where is the gesture of destruction of norms, the rejection of all rules of syllabic or accent division? These rules are repealed, but in their place there appear other, invented or created by the author himself (a question of over-organisation and hybridisation), or 
prompted by the unconscious and included in the expression. The corpus of the sonnet is completely picked apart here, torn or mutilated, which is the result of rape of language and of all the conventions that shape traditional poetry. Excess of conventions leads to artificiality and repetition of cliché phrases and formulae (as in the earlier cited subtitle to Sontotu 12). Sonety totalne are a reflection of consciousness that does not want to surrender or not be paralysed by various systems (power, art), are an expression of rebellion against all systems, rules and principles, against the Law and the Norm, are blasphemous and anarchic, saturated by repulsive physical consciousness (dirt, faeces, secretions of the human body, mutilated body - Julia Kristeva's abjection):

Sontot 14 Filozofia czynności fizjologicznych

Smrodu i wielkiej poe

zji nigdy nie za wiel

e fizjologicznych czy

nności nieuchronny u.

Rok kału moczu się śc

ele i wydzielina rop

na i miesięczna jatka

On the other hand, they are also the image of the body in paroxysm, the body driven by impulses, which determines the shape of these texts, which are subjected to total destruction and they are to be found in pieces, in dispersion. The texts are filled with profanity, and some of them consist of only of this:

Sontot 19 Sontot monolityczny $w$ reżymie spacjalnym. [Sontot 19 monolithical Sontot in a spatial regime] 
[And prick/ And prick/ And prick/ And prick/ And prick/ And prick/ And prick/ And prick/ And prick/ And prick/ And prick/ And prick/ And prick/ And prick]

Vulgarisms constitute the expression of the situation of lust, connecting the subject with a rebellious gesture, with kineticism; their excess being arranged in the image of the body traversed by urges is associated with the movement of rejection and appropriation of the other.

Poetic speech is not reduced to simply a matter of articulating vulgarity. It is rather about creating a discourse that rejects aestheticism (beauty and sense this is a fundamental matter when the sonnet becomes the main subject of destruction), a discourse in which poetic language falls into the destructive space. In these texts it is possible to hear the agitated voice of the poet, but at the same time as the poet the shaken, agitated body torn by impulses speaks. The act of writing - as the poet himself wants - should rely on "psychic eruptions" and this "without attempts to subject them to preliminary intellectual processing". Sontots become a mixture of "lyricism of logical lectures, paradoxes of gibberish, gross vomiting and shouting." The body of the sonnet breaks up in the crazed rhythms of words and unconventional, unpredictable graphs and takes on a form that depends directly on the impulses of the body involved in the act of writing. 



\section{Somatext: word, picture and rhythm}

\section{Somatext and intratypography}

What does "somatext" mean? First of all, the obvious, unequivocal association with feminist literary criticism ${ }^{228}$; however, I am not talking about this kind of understanding because the subject of reflection in this chapter will not be texts that directly address corporeal issues in terms of sexual difference. However, they are bound closely with the body on account of the specifics of their perception, in which various senses are actively involved (sight, hearing, touch). Apart from the aforementioned meaning, a French term, "Somatexte", also exists, which appears in a totally different context in works based on cognitivism ${ }^{229}$. In the cognitive approach, Somatext (the capitalisation of this term is used here as cited above by Christian Bonnet) is defined in the context of typography and communication as that which gives the Text printed form: paper type, its format, weight, colour, spacing, empty space, arrangement of the page, colours and illustrations, font type as well as background colours, letters, frequency of illustrations. Text is a collection of typographic characters in print, based on characters ordered in time and requiring linguistic analysis. Somatext is a collection of non-linguistic signals perceived by the senses and constituting an embodiment of the text, its "body". Somatext constitutes a supplement to the Text - such as signifiant and signifié - there is a physical bond between them. The text is intended for reading and contains information; Somatext in turn must be seen and serves to uphold the relationship with the reader. According to the findings of the neurolinguists, the subcortical structures of the brain are responsible for the emotional support of reading - in this way, the signals of the Text and the signals of the Somatext produce a precortical, emotional, preconscious response, and thereby exert a significant influence on the reader who associates them.

228 See, for example, U. Śmietana, Od écriture femininine do somatekstu, „Przegląd Filozoficzno-Literacki” 2003, No. 1(3), pp. 153-171; M. Świerkosz, Feminizm korporalny w badaniach literackich. Próba wyjścia poza metaforykę cielesności, „Teksty Drugie" 2008, No. 1/2, pp. 75-95.

229 See Ch. Bonnet, La Communication imprimée, „Communication et langages” 1990, No. 86, pp. 37-52. See also A. Dubied, Les dits et les scènes du fait divers. Travaux de sciences sociales, Paris 2004, p. 284. 
The term "somatext" can be complemented in particular by proposals from Henri Meschonnic ${ }^{230}$, which also refers to the layout of the text on the page, to the various typographic characters which are particular signals to the reader, and which affect the rhythmic formation of the text. This is about the term "intratypography" (typography inside the frame of the text written in the page), which, according to this eminent expert, explains rhythm problems represent a collection of elements that are linked in a special way with the visual page of text: these may be characters separating words that differ from their syllables (this is an effect which cannot be emphasised in speech), writing words in capital letters inside a sentence, at the end or in the middle of a word or verse, parentheses or parentheses unopened or unclosed, multiple parentheses, different types of fonts within single words or phrases, irregular text layout on the page, playing with different types of fonts, punctuation signs which become metacharacters. Intratypography is directed against the metaphysics of the sign and logocentrism, and also undermines the primacy of signifié and linearity of text. It is not surprising that the researcher uses examples of texts by Stéphane Mallarmé, Paul Claudel, Guillaume Apollinaire, Pierre Reverdy, Raymond Roussel - but it must be stressed that this is done with full historical awareness of typographic practices (in different historical moments the development of such practices served different purposes and carried meaning differently). The terminology proposed by Meschonnic will prove useful in many textual analyses and will reveal the rhythm spaces functioning in selected literary texts.

Bonnet is limited in his arguments to analysis of particularly useful texts (advertisements, tourist information, popular science editions, etc.), but does not exclude the bibliophilic editions of fine literary works or editions of art history. There is nothing to prevent us from taking a look at these atypical poetic forms, visual poetry (below we will review various types of poems that contain a brief historical description of a particular genre and try to read specific examples focused on their sensory reception) or a few book editions in which the word and the image blend into an unbreakable relationship of coexistence. Here I am interested in the excellent and revealing typographic editions made by Franciszka and Stefan Themerson in the framework of the activity of their London publishing house Gaberbocchus. Also in this case the reception must be extended to somatic experience.

230 H. Meschonnic, Lenjeu du langage dans la typographie, „Littérature” 1979, No. 35, pp. 46-56. See also H. Meschonnic, Espaces du rythme, [in:] idem, Critique du rythme. Anthropologie historique du langage, Lagrasse 1982, pp. 297-335. 


\section{Intratypography and poetic texts $\mathrm{s}^{231}$}

There are many different poetic forms in which intratypography is essential to their reception and their rhythmic form. A quick overview of these forms could start with logogriphs ${ }^{232}$. These are works which are most often in verse, and the name is derived from the Greek words logos ('word') and grïphos ('puzzle'). Various sources also use the names "enigma", "griph" or simply "puzzle". The logogriph contains in itself the name and surname or name of an object that the reader needs to guess by the arrangement of appropriate syllables based on the combination. Thus, reading logogriphs engages the reader's various senses, without which deciphering the hidden meaning would not be possible. One of the most commonly cited logogriphs is one authored by Adam Korczyński, written in the last two lines of Wizerunek preceding his work Wizerunk złocistej przyjaźnia zdrady published by Roman Pollak from manuscript in 1949:

\section{WIZERUNEK}

Złocistej przyjaźnią zdrady

mężowi

bystrej żony obrysowany na przestroge,

bo

Felix ąuem faciunt aliena pericula cautum alias

Szczęśliwy, co po cudzej tej strasznej przygodzie

Nie uderzy o skalę, której nie znać w wodzie -

A ten na punktów dziewięć rozporządzony będąc dla nietęsknice czytelnika żartownemi lanczaftami a raczej occurrentiami jest intermediowany.

Author

Imię ma z raju, ski - ogon przezwiska, rok - wspacznie głową, czyn - w środek się wciska. ${ }^{233}$

231 In subsections 2 and 3 I use fragments of text previously published on the site Sensualność $w$ kulturze polskiej edited by W. Bolecki (http://sensualnosc.ibl.waw.pl) (accessed: 24.02.2014). For the purposes of this text, they have been modified and adapted to specific theoretical assumptions.

232 See, for example, I. Adamczewska, [entry:] Zagadka, [in:] Słownik rodzajów i gatunków literackich, ed. G. Gazda, S. Tynecka-Makowska, Cracow 2006, pp. 799-800; S. Nieznanowski, [entry:] Enigmat, [in:] Słownikliteraturystaropolskiej.ŚredniowieczeRenesans - Barok, ed. T. Michałowska, Wrocław 2002, pp. 197-199; T. Kostkiewiczowa, [entry:] Logogryf, [in:] M. Głowiński, T. Kostkiewiczowa, J. Sławiński, A, Okopień-Sławińska, Słownik terminów literackich, Warsaw 1998, pp. 287-288.

233 Quotation after: Polska Biblioteka Internetowa: http://www.pbi.edu.pl/book_reader. php?p=4709 (accessed: 9.06.2014). 
["IMAGE // A golden friendship of treason / against a husband / by a sharp wife outlined by a warning / because / Felix quiu faciunt aliena pericula cautum / alias / Happy, that after somebody else this terrible adventure he will / Not hit a rock which he does not know in water - / And this one on nine points disposed of being for her- / longings of the reader with jokes and lanczafts and rather occur-/rents are intermediated. / Author / Name has from paradise, the ski - the tail of a nickname, the year - warped head, the act - the middle is pressed"]

The name of the author is entered in the form of a puzzle in the last two lines, and its decryption is not too difficult. Reading demands the involvement of both visual and hearing senses (it is necessary to transform according to the stylistic rules of anagrams - „wspacznie” - the word „rok”, which gives „kor”, the first element of the author's surname). The rhythm of this text is also based on intratypography (the notation of some lines and words in italics, disproportions between the length of particular lines).

Another example of logogriph, a bit more complex, is written by Charles Dufresny, a French playwright and journalist working at the turn of the seventeenth and eighteenth centuries:

Sans user de pouvoir magique,

Mon corps, entier en France, a deux tiers en Afrique.

Ma tête n'a jamais rien entrepris en vain;

Sans elle en moi tout est divin;

Je suis assez propre au ruslique

Quand on me veut ôter le cœur.

Qu'a vu plus d'une fois renaître le lecteur?

Mon nom bouleversé, dangereux voisinage,

$\mathrm{Au}$ Gascon imprudent peut causer le naufrage. ${ }^{234}$

The basis of this logogriph is the word „orange”. By applying reductions and transpositions, we get further words hidden in it: „Oran”, „or”, „ange”, „orge”, „an” and arranged anagrammatically, „Garone”. Also in this case, phonetics plays a major role decoding the logogriph, while reading the words it is necessary to see and to hear. These are highly conventionalised works, drawing readers to play and have fun.

The tautogram is also an interesting form (the word is formed from a combination of the Greek words tautós, meaning 'the same' or 'the same as', and grámma, meaning 'letter'). This is the type of text in which all words start with the same letter. The author of one of the most famous tautograms is the Dominican

234 Espaces français.com - http://www.espacefrancais.com/topics/enigme-charadelogogriphe.html\#4 (accessed: 9.06.2014). 
Johannes Leo Placentius, who in 1546 under the pseudonym Publius Porcius published a work entitled Pugna Porcorum (Battle of the Pigs) consisting of 253 hexameter lines. Works of this type were often either ludic or satirical, but they also constituted a sort of conventionalised play or literary game.

The notation of a tautogram means that it gains a valuable visual asset that needs to be taken into account when reading it. But this is never limited to deciphering the meaning of the words alone. Repeating the same letter repeatedly influences the rhythmicising of the line of speech. In tautograms the rhythm of the text is often based on the rule of enumeration, like for example in this poem by Witold Hulewicz from the volune Miasto pod chmurami, published in Vilnius in $1931^{235}$ :

Wilk, Wici, Wiosna, Witold, Wierność i Wigilia

Więź, Wieczerza, Wijatyk, Wilenka i Wilia

Winnica, Wiosło, Wiara, Wiersz, Wicher i Wieniec:

Oto na twych stuleciach młodości rumieniec.

The rhythm of this poem is based on regular metre (13-syllable (Polish alexandrine) syllabic poem with the caesura after the seventh syllable: $7+6)$, but also on the multiple repetitions of the phonetic soft v' and on counting and evennumbered feminine rhymes in the aabb pattern that holds the whole expression together. The rhythmic scheme of tautograms is not limited to language itself, as it also involves visual rhythm (in this case it is about the repeated capitalisation of the letter "W") and during reading engages both sight and hearing.

In the twentieth century the tautogram became an important element of the "potential literature" of the OuLiPo group - here is poetic text written in prose by Jean Lescure titled Tautogramme, and taken from La littérature potentielle:

Z’ai nom Zénon

Au zénith un zeste de zéphyr faisait zézayer le zodiaque.

Dans la zone zoologique, bon zigue, zgzagait l'ouvrier

zingueur, zieutant les zèbres mais zigouillant plutôt les

zibelines.

Zut, suis-je déja à Zwijndrecht, à Znaïm, ou à Zwevegem, à

Zwicken ou sur le Zuyderzee, à Zermatt ou à Zurich.

Zélateur de Zaroastre, j’ai le poil sombre des chevaux

zains.

Mais ayant joué au Zanzibar un zazou m’a zasté les parties

zénithales selon une method zéthétique. Aussi c'est

235 Quotation after: J. Tuwim, Pegaz dęba, Warsaw 2008, p. 155. 
entre le zist et le zest que j'ose zozotter: zero. Mais zero zoniforme, zero zoospore, zero zoophagique. Et pas de zizanie entre les zouaves à propos de zizis - hien? zero. ${ }^{236}$

In this text, little remains of convention, game, joke, word play or - as said by Tuwim - „tautohames”. It is clear that it uses the whole phonetic sphere, which introduces supplementary methods of meaning into the text. We are evidently dealing with signifiance. In Lescure's text specific phonetic elements return transversely and translinearly, mainly lower- and uppercase type in the middle of the text (intratypography) and groups of vowels $z e, z a$. Signifiance of the text is formed by a series of most commonly appearing vowels or by relationships between particular groups of vowels, but also by the text, its strophic division and the highlighting of words in capital letters. This is a complex process in which the subject of the text escapes the logic consistent with ego-cogito and deconstructs itself. It is counter to meaning and cannot be reduced to communication, representation or expression, because it is associated with sensual pleasure of reading. In this way, the tautogram appears as a slightly more complex phenomenon than that described in traditional dictionaries and textbooks. Here is one more example from the OuLiPo group's work, titled Clef du petit abécédaire illustré (Klucz do matego ilustrowanego abecedariusza), which is based on the tautogram and can be read successfully according to the rules described above:

1 Bah! Beh! Bi beau: but

2 Caquet: qui cocu?

3 Dad est dit dodu

4 Faf' est fifre au fû

5 Gag: Eh, Guy, gogues hue!

6 Ja j’ai gît, jauge eu

7 Là l'est, l'îlot lu

Lalo lit l'Élu

8 Mâme et mime, oh mue!

Ma maie, mi-mot, mue

9 Nanne: $\mathrm{N}$-ine aux nues

10 Pape épie, Pô pue

Pas pépie, pope, hue

11 Rare est rire aux rues

12 ça! Cesse, hisse au su!

Sas est-ce, hi, Sausurre?

13 Taté, Tito tut

236 OuLiPo, La littérature potentielle (Créations, Re-créations, Récréations), Paris 2003, p. 113. 
14 Va! Veux! Vive au vu!

15 Qu'Saxe ex-X,! Oh que su...!

16 Za, zéziz... Oh zut! ${ }^{237}$

Speaking about intratypography, it is also worth referring to versus quadratus, in literal translation "square poem", Julian Tuwim called this a "poem in a pattern"238. The construction principle of this type of text is very simple: the text read horizontally and vertically sounds the same. It is a kind of literary game based on multiple and varied spatial repetitions. This means that the visual sense is involved in a particular way in reading. The poem is like a puzzle that can be read in many different ways. Repeatedly combining multiple combinations becomes an important mnemotechnical factor that makes the text easy to memorise. One of the most interesting examples of such a poem is Wojciech Waśniowski's work Apostrophe published in his book Wielkiego Boga wielkiey Matki ogrodek from 1644 (see Illustration 1$)^{239}$.

Illustration 1: W. Waśniowski, Apostrophe, [in:] idem, Wielkiego Boga wielkiey Matki ogrodek..., Cracow 1644, p. 69, http://www.wbc.poznan.pl/dlibra/ doccontent?id=48903\&from=FBC (accessed: 9.06.2014)

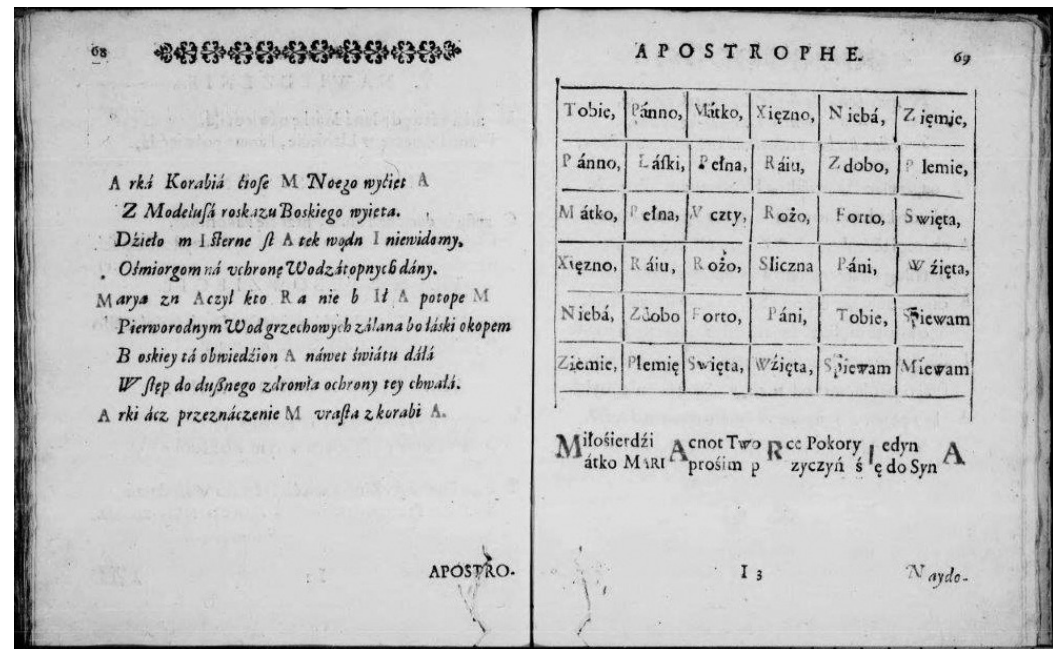

237 Ibidem, p. 301.

238 J. Tuwim, Pegaz dęba..., p. 396.

239 W. Waśniowski, Apostrophe, [in:] idem, Wielkiego Boga wielkiey Matki ogrodek..., Cracow 1644, p. 69, http://www.wbc.poznan.pl/dlibra/doccontent?id=48903\&from=FBC (accessed: 9.06.2014). 
Under the text emphasising the "square" layout of the poem, the author additionally added a serpentinum with the name MARIA, to whom the apostrophe is addressed, and the whole work is devoted to. Rhythm is shaped here by typography - text placed in a square, similarly with individual words. In serpentinum capital letters intertwine two overlapping sentences. Formation of rhythm also includes regular metre - a $12(6+6)$ syllabic verse, all are two syllable with the main accent on the first syllable, and the whole closes with exact rhymes, adjoining aabbcc. A transcript of the main text is as follows:

\begin{tabular}{|l|l|l|l|l|l|}
\hline Tobie, & Pánno, & Mátko, & Xięzno, & Niebá, & Zięmie, \\
\hline Pánno, & Łáski & Pełna, & Ráju, & Zdobo, & Plemie, \\
\hline Mátko, & Pełna, & Vczty, & Rożo, & Forto, & Swięta, \\
\hline Xięzno, & Ráju, & Rożo, & Sliczna, & Páni, & Wźięta, \\
\hline Niebá, & Zdobo, & Forto, & Páni, & Tobie, & Spiewam \\
\hline Ziemie, & Plemię & Swięta, & Wźięta, & Spiewam & Miewam \\
\hline
\end{tabular}

\section{Words in pictures, pictures in words}

From the very beginning of its existence, visual poetry involved the reader's various senses in reading. Its reading is directly related to the body of the recipient and to the somatic experience. In all types of this kind of poetry perception is never limited to just one sense, each time it is necessary to see these works, and also to hear. Reading starts with the picture; it is necessary first to see the image and the text, and then include the sense of hearing into the reading. Pages of books containing these types of texts become pages performatives, pages of writing and/or reading, a kind of dramatic process of meaning in which individual acts and scenes take place simultaneously. Text and Somatext become inseparable in the case of visual poetry. The page on which the printed text appears becomes a rhythm space, and it is not based solely on the word, but on the image closely linked to the word.

It is worth taking a closer look at some selected examples of this type of poetry. The first such texts, known as, technopaegnia (the name comes from two Greek words techne - 'craft, art' and paegnion - 'game, fun'), appeared around the year 300 BCE and are connected to Simmias of Rhodes, Theocritus of Syracuse and Dosiadas of Crete (circa $100 \mathrm{BCE}$ ), who many sources recognise as masters of this form ${ }^{240}$. Technopaegnia did not only mimic the subject but also required

240 See P. Rypson, Piramidy, słońca, labirynty. Poezja wizualna w Polsce od XVI do XVIII wieku, Warsaw 2002, p. 12. 
a special reading from the reader - who was forced to read the first and last lines, then the second and the penultimate ones, etc., and so the text was finally put together (examples could be Simmias's Egg or $A x$ ). As in all cases of visual poetry, reading could not be restricted solely to the deciphering of verbal meanings, because its shape also depends on the perception of the image - the word and the image thus enter into the relation of coexistence. The rhythm of the text also depends on the rhythm of the picture. These were highly conventionalised works, based on the principle of play. Later in time they became the prototype of carmina figurata, and also many other types of visual poetry.

Carmen figuratum, also known as a shaped poem or shaped verse, in German as Bilderlyrik, is a piece arranged on the page in the shape of the object referred to in the text. The original model for these types of works is the earlier mentioned Technopaegnia, which inspired many of the later solutions appearing in English metaphysical poetry or in Old Polish literature, for example Simmias Rhodius and his Wings or the Altar poems of Dosiadas and Besantinus, and later in the seventeenth century George Herbert's famous works The Altar and Easter $W_{i n g s}{ }^{241}$. Works of this type were not limited to aesthetic or human conventions, because they also served religious or magical purposes, combined the pleasure of decryption with the pleasure of reading, which in their case could never be reduced to linear reading of particular elements of the text, as the order of reading is ordered by the graphic shape, the picture in which the text is laid out. Alongside the sense of sight, the sense of hearing is often involved in the reception of shaped poems. The poems need to be seen and heard, because they are also based on sound combinations, series of anagrams, which lead the texts into a broadly expanded sphere of signifiance, creating supplementary meaning values of the entire text.

The popularity of picture poetry does not only stem from the tendencies associated with conventions. This is not so much about crossing convention, about some kind of transgression, but more about expanding the means of artistic expression (word combined with image), about giving the text a multiform character, in which somewhere between the word and the picture there is interference, like they overlap as if waves in some physical phenomenon. Olden time carmina figurata often resemble drawings (sometimes they are even drawings to which words have been added). This is a very important feature of them, because the whole speech begins with form, which links with Plato's idea indicating "visible

241 S. Barańczak, Antologia angielskiej poezji metafizycznej XVII stulecia, Warsaw 1991, pp. 207 and 212. 
form". A sketch, as Jean-Luc Nancy rightly says, is an Idea, and also "it is the true form of the thing. Or more exactly, it is the gesture that proceeds from the desire to show this form and to trace it so as to show the form"242. The Latin meaning of the word designo refers to description, marking, indicating, designation or formation. In picture poetry, the word cannot exist without the image, and the image cannot exist without the word -- it is a bond that cannot be broken in the case of this genre. This happens in the work by Wojciech Waśniowski ${ }^{243}$ (poem in the shape of a star, an example of a Marian work; see Illustration 2).

Illustration 2: W. Waśniowski, Gwiazda, [in:] idem, Wielkiego Boga wielkiey Matki ogrodek..., Cracow 1644, p. 74, http://www.wbc.poznan.pl/dlibra/ doccontent?id=48903\&from=FBC (accessed: 25.09 .2014$)$

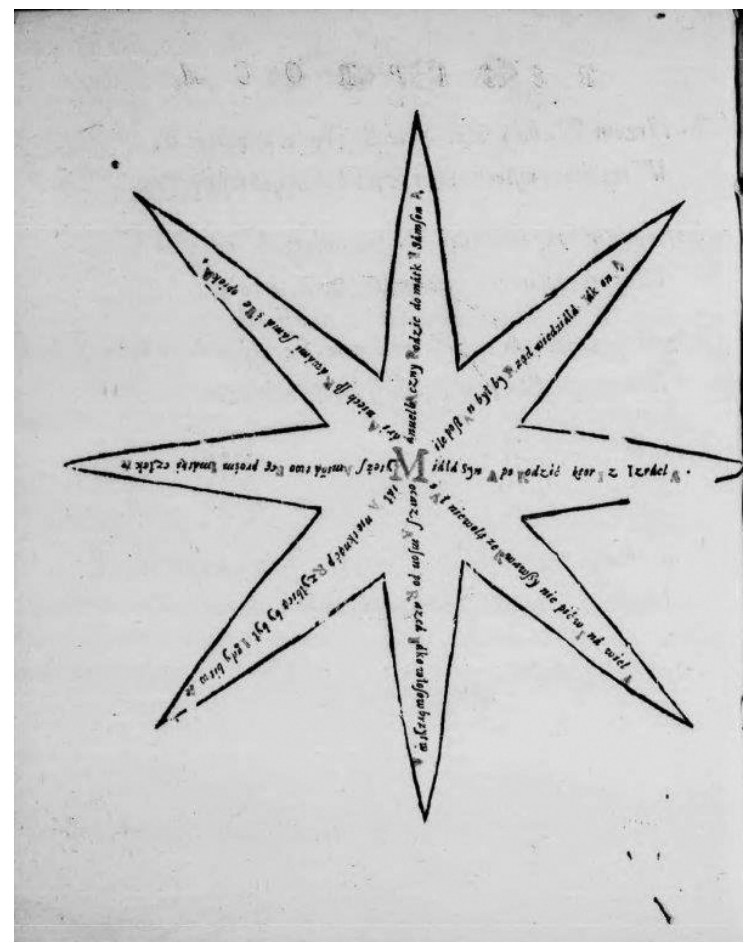

242 J.-L. Nancy, The Pleasure in Drawing, transl. Philip Armstrong New York 2013, p. 10.

243 W. Waśniowski, Gwiazda, [in:] idem, Wielkiego Boga wielkiey Matki ogrodek..., p. 74, http://www.wbc.poznan.pl/dlibra/doccontent?id=48903\&from=FBC (accessed: 25.09.2014). 
" $M$ ", a monogram of the name Maria, is inscribed in the very centre of the poem, from which the name of Maria emanates radially written in capital letters in lines of an eight-pointed star. The entire book is composed of short poetic texts (Drzewká, Ziołká, Kwiećie), and next to them is carmen cancellatum and a few "curving poems" (serpentinum) - as the author names them himself. The matters are similar in the work by Maciej Czaplic ${ }^{244}$, which is arranged in the shape of a branch of rosemary and whose verses divide according to the arrangement of twigs (see Illustration 3).

Illustration 3: M. Czaplic, Podarek na Slawne Wesele Zacnie Urodzonych Ulubiencow...

Poznan 1662, s. 7, http://www.wbc.poznan.pl/dlibra/docmetadata?id=66452 (accessed: 25.09.2014)

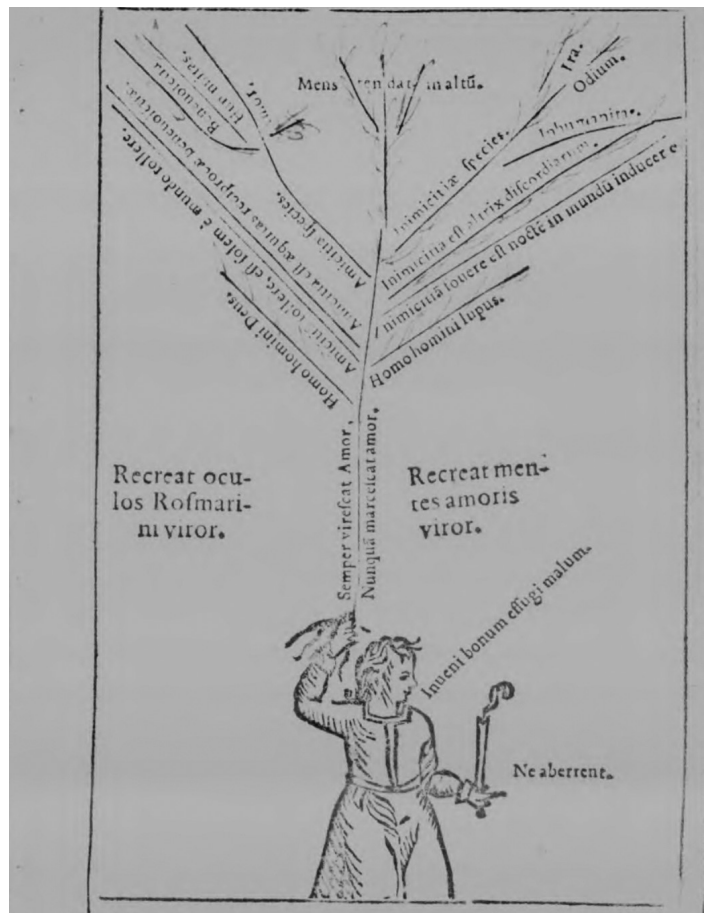

244 M. Czaplic, Podarek na Slawne Wesele Zacnie Urodzonych Oblubiencow, Szlachetnego Pana, P. Stephana Zabinskiego, y Szlachetney Panny, P. Anny Chrosciewskiey. Przez Macieia Czaplica Klec. ofiarowany, J. Rossowski, Poznań 1622, p. 7, http://www.wbc. poznan.pl/dlibra/doccontent?id=66425\&from=FBC (accessed: 25.09 .2014 ). 
Amongst the forms of visual poetry we are interested in is the emblem ${ }^{245}$. The name comes from the Greek word émblèma meaning 'insertion' or 'something put on'. The beginnings of the genre are linked to the famous work of Andreas Alciatus Emblematum libellus from $1531^{246}$, which was a set of epigrams of an ekphrastic nature (descriptions of various works of art). The first publisher of Alciatus's work decided - against the author's intentions - to publish the texts together with the prints and thus created the foundations of the genre, which gained great popularity and developed substantially in successive centuries. The genesis of the genre associated with the views of the neoplatonic school on the cognitive advantages of plastic arts ${ }^{247}$ says much about the correspondence of the arts and in many respects goes back to times contemporary to us, in which the relationship between the image and words is becoming stronger.

Also, in this case, the word and the picture come together into an inseparable relationship of coexistence. Researchers of verbal-visual relations in the Old Polish era speak of paravisuality as a distinctive feature of Old Polish literature ${ }^{248}$. The image and the word placed next to each other on the page illuminate each other, lending one another their cognitive values and engaging the reader's senses in a special way while reading. Reading could not be limited to reading the linear order of the writing, but the whole process was to read the iconic message with the verbal message. The combination of natural and artificial signs was supposed to enrich the cognitive qualities of the work. There was a special kind of oscillation between the word and the picture, which was based on their distinctness and mutual proximity. This had a great influence on the perception and interpretation of the text, and it also created a sensual model of reading. The image contained in the emblem underwent textualisation, and in turn the text was visualised. Here, the image and text were like recto and verso. The ekphratic nature of the emblem, based on making the object present or visible with the help of the poetic word (description), was further enriched with the help of the image. Speaking of the relationships between image and word, Jean-Luc Nancy draws attention to the fact that "In looking at the image, I always textualise it in

245 See properly: J. Pelc, Obraz - słowo - znak. Studium o emblematach w literaturze staropolskiej, Wrocław 1973; J. Pelc, [entry:] Emblemat, [in:] Słownik literatury staropolskiej..., pp. 194-197.

246 A. Alciatus, Emblematum libellus, ed. R. Krzywy, Warsaw 2002.

247 R. Krzywy, [entry:] Emblemat, [in:] Słownik rodzajów i gatunków literackich..., p. 203.

248 H. Dziechcińska, Parawizualność literatury starpolskiej jako element ówczesnej kultury, [in:] Słowo i obraz. Materiały sympozjum Komitetu Nauk o Sztuce Polskiej Akademii Nauk, ed. A. Morawińska, Warsaw 1982, p. 97. 


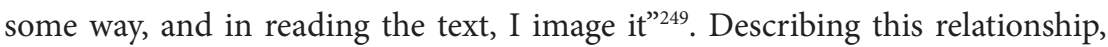
Nancy also talks about textualisation and at the same time an update which is closely intertwined (in this, the soul and body participate, so form and depth, and the interpretation itself consists of animation as embodiment and embodiment as animation, for shaping depth and deepening the shape).

The main formal determinants of the emblem as a genre were defined by Jacobus Pontanus in Poeticarum institutionum libri III in 1594. The emblem consists of three elements: inscription (in other words, epigraph, motto or lemma) containing generalised sense of the whole, picture (icon, imago or pictura) and subscription in the form of text. The picture forms the "body" (corpus) of the emblem (the conventional rule underlines the somatic character of this species by its very name), the poetic text was its "spirit" (animus) and "soul" (anima) was its inscription. In Zbigniew Morsztyn's collection Emblemata, written around $1675-1680$, the construction of individual texts is based on the inscription taken from the Bible, which develops the text (below is Emblem 7):

Człowiek chory podstawia kubek pod krew świętą płynącą z ran Chrystusa Pana.

Napis. fetory leczy wszytkie niemocy moje. Psalm 102, 3.

Na śmierć choruje i już moje zdrowie

Cale zwątpione, już mej biednej głowie

Przydzie podziemne nawiedzić podwoje;

Ale co gorsza, że nie tylko moje

Ciało, lecz oraz dusza ciężko stęka,

Drży i sądu się ostatniego lęka.

O Panie JEZU, któryś tu choroby

Na ziemi będąc leczyl, któryś groby

Zmarłych otwierał, że zdrowi stawali

I w ciele Twą moc boską ogłaszali,

Jako na Puszczy niegdy ukąszeni

Od srogich wężów, byli uzdrowieni,

Na węża tylko patrząc miedzianego:

Tak ja na Ciebie ukrzyżowanego,

Na bok Twój święty, na ręce i nogi

Poglądam, z których balsam płynie drogi.

Lekarzu święty, niech nim uleczony

Od forty śmierci będę powrócony. ${ }^{250}$

249 J.-L. Nancy, Au fond des images, Paris 2004, p. 130, transl. A Dziadek, see also The Ground of the Image, transl. Jeff Fort New York 2005, p. 69

250 Z. Morsztyn, Emblemata, edition Paulina and Janusz Pelcowie, Warsaw 2001, pp. 18-19. 
['An ill person places a cup under the holy blood flowing from Lord Jesus' wounds./ An inscription, stench heals all my infirmity." Psalm 102, 3. // "I am dying and my health / is all in doubt, soon my poor head / will have to visit the underground chambers; / Unfortunately, not only my / Body, but also my soul heaves a sigh, / Shivers and fears the final judgement. / Oh, Lord Jesus, who here on earth / cured illnesses, who raised the dead / from graves and made them well again / And through their bodies they proclaimed your divine power / Like those stung in the desert once / By fierce snakes, they were cured, / Just by looking at a copper snake: / that is how I'm looking at You, crucified, / At Your holy heart, hands and feet, / Where the precious balm flows from. / Oh, holy healer, let the balm cure me/ and bring me back from the brink of death"]

Amongst Polish artists of this genre noteworthy are Jan Dantyszk who wrote in Latin In emblema Gattinarae (1531), Mikołaj Rej, who in Źwierzyniec used emblems from the collection of Alciatus, and also Jan Kochanowski. The peak stage of the development of the emblem occurred within the Baroque period, and amongst the most important creators of this species are Andrzej Maksymilian Fredro and his Peristromata Regum ${ }^{251}$ written in Latin prose, and also the already mentioned Zbigniew Morsztyn and Stanisław Herakliusz Lubomirski and his Adverbia moralia (see Illustrations 4 and 5).

Illustration 4: S.H. Lubomirski, Adverbium moralium, Warsaw 1688, p. 40, http://www. pbi.edu.pl/book_reader.php?p=41038 (accessed: 25.09.2014)

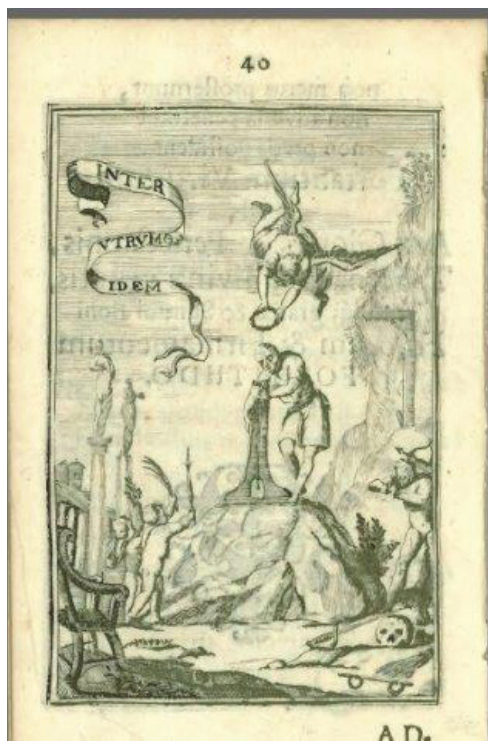

251 A.M. Fredro, Peristromata Regum, Gdańsk 1660, p. 380. 
Illustration 5: S.H. Lubomirski, Adverbium moralium, Warsaw 1688, p. 41, http://www. pbi.edu.pl/book_reader.php?p=41038 (accessed: 25.09.2014)

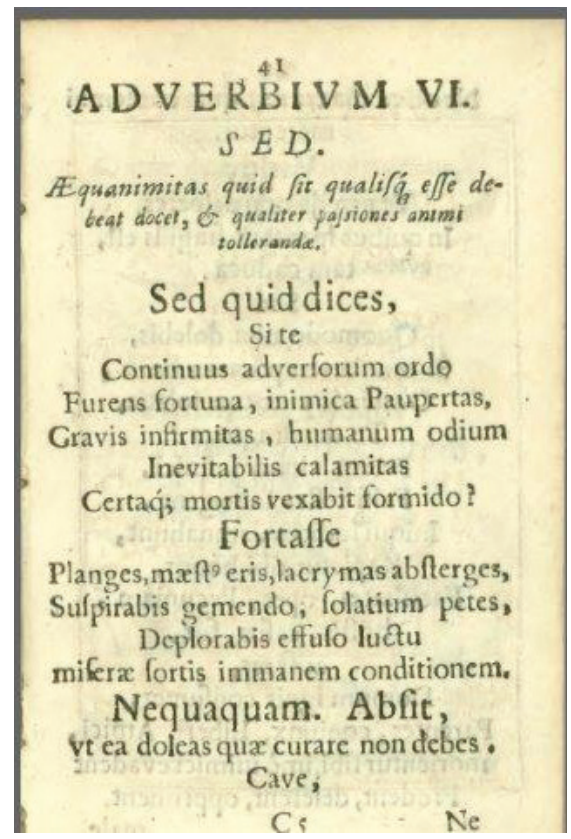

This superb work contains 15 emblems from Tylman of Gameren's custom-made copper engravings. In Adverbia - as can be clearly seen on the reproductions the graphic layout of the text on the page was also of great importance, and thus typography (letter size, italics in inscriptions and inside subscriptions), the composition of the text itself was based on the frequent repetition of conjunctions, adverbs or prepositions: semper, cum, non, nec, in, ad, certa, incerta. Such elaborately built texts worked through the reader's various senses, which forced them to see and hear them.

Emblems are also connected with stemmata (or stemma from the Greek word stémma, meaning 'ribbon'). Originally, these were scrolls noting the genealogy of the Roman families. Over time, a variant of the emblem came to be closely linked to heraldry. This form combines an image which is a coat of arms and text in the form of a short epigram referring to the image. The text depicts and interprets the motifs contained in the coat of arms in a symbolic or moralistic manner, often taking the form of a panegyric. Stemmata were written, amongst others, by 
Mikołaj Rej, Jan Kochanowski and Mikołaj Sęp-Szarzyński. They became particularly popular in the First Republic, experiencing the peak of interest in the seventeenth and eighteenth centuries. In the case of this form we are also dealing with the coexistence of image and text. Widespread use of this form in dedicated books or in biographies was associated with the broad development of the emblem (in some cases the form "stemma", "in stemma" or "emblem" appeared in titles, indicating a strong bond between genres). In the edition of Rytmy abo wiersze polskie by Sęp-Szarzyński from 1601 there is an image depicting the coat of arms and a poem attached to it Na herb Jego M. Pana Jakuba Leśniewskiego podczaszego ziemie lwowskiej:

Gryffowie strzegą złota. y biią sie o nie,

Tak w południowey iako y w pułnocney stronie.

Niebożęta Pigmei trudność z nimi maią,

Ktorzy się o ten kruszec z pilnością starała.

Ale Polscy Gryffowie nie tak Sądni złota,

Jako wolnoś i stoże, w których ta ochota,

Że y umrze za wolność zyskiem poczytaią,

Skąd też y od oyczyzny dawną wdźięczność znaią.

Mimo insze przykłady, y zacny Podczasy,

Herbowym y oyczyźnie iest wszelkimi czasy,

Powodem do wolności krwią przodkow nabytey,

$\mathrm{Z}$ okazaley swey chęci bynamniey nie skrytey. ${ }^{252}$

["The Gryffs guard the gold and fight over it / Both from the south and from the northern side. / Poor Pigmies are troubled by them / As they too are urgently trying to obtain the ore / But the Polish Gryffs are not as greedy for gold / As they are guardians of freedom and such is their will / That falling for freedom will be their best reward / For they know their homeland's gratitude. / Among other examples, the respectable Cup-bearer / will hold the homeland's coat of arms forever / as the symbol of freedom earned with the ancestor's blood / with flamboyant and outright pride"]

Although the function of the stemmata was different to that of emblems, the rules of their reading are very similar. Text and Somatext remain closely related,

252 M. Sęp-Szarzyński, Rytmy abo wiersze polskie, 1601, http://books.google.pl/book $s ?$ id=Yf4hAAAAMAAJ\&pg=PR3\&lpg=PR3\&dq=miko\%C5\%82aj+s\%C4\%99p+ szarzy\%C5\%84ski+rytmy+albo+wiersze+polskie $+1601 \&$ source $=$ bl\&ots $=$ Mxo4N O5K5H\&sig=GF91DPDaK5Vyi4z6sDWJ1lw7OcM\&hl=pl\&sa=X\&ei=UKBIVKi 2Le-v7AbBhYD4Cw\&ved=0CD8Q6AEwBQ\#v=onepage\&q=miko\%C5\%82aj\%20 s\%C4\%99p\%20szarzy\%C5\%84ski\%20rytmy\%20albo\%20wiersze\%20polskie\%20 $1601 \& \mathrm{f}=$ false (accessed: 22.10 .2014$)$. 
and reading cannot be confined to reading a linear script; the image illustrates the text, and the text refers to the image, which constitutes its free interpretation.

Stemmata were sometimes put into panegyrical cycles, which is the case, for example in a collection published in 1730 by Karol Sawicki entitled Krzywda po wzgardzonym dla Boga swiecie... y zdptaney herbowey podkowie..., attributed to Anna Ludwika Rzewuska ${ }^{253}$. A horseshoe, an element of the Rzewuski coat of arms, is contained in the title and appears in the central position of subsequent paintings and is noted in allegorical texts assigned to them. The image was placed in the middle of each card, above it there was a text closely related to it, with the same text underneath in Latin (see Illustration 6).

Illustration 6: K.P. Sawicki, Krzywda po wzgardzonym..., http://polona.pl/item/318802/4/ (accessed: 18.10.2014)

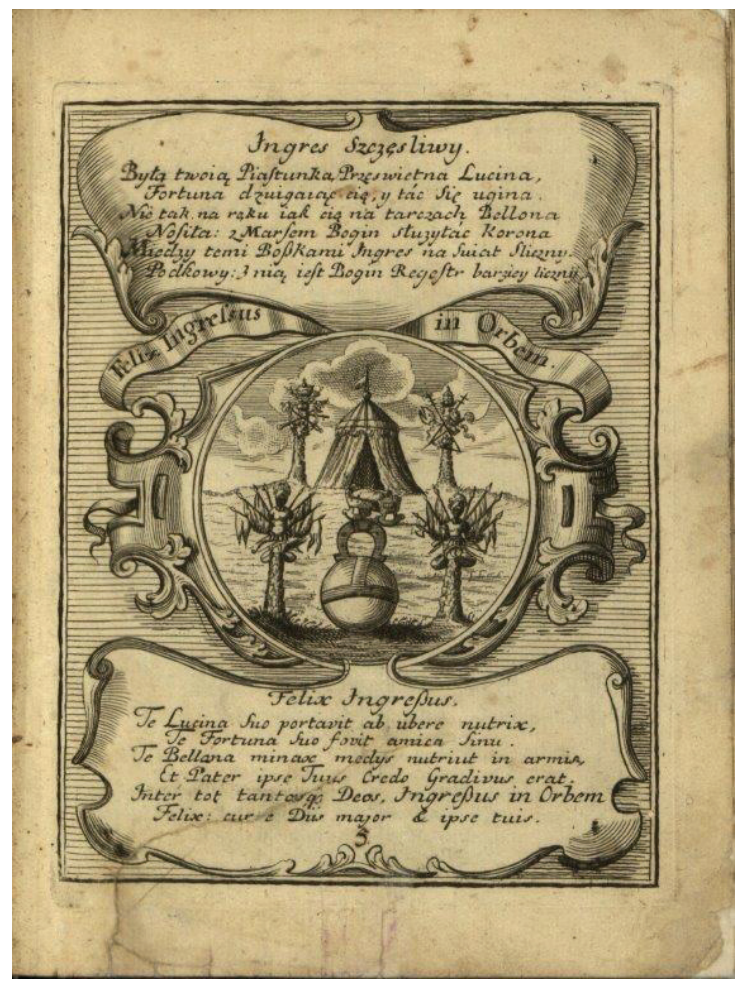

253 See http://www.polona.pl/dlibra/doccontent?id=1252\&from=FBC(accessed: 25.09.2014). 
Let us also look at the labyrinth poem, which is considered a part of visual poetry, with origins dating back to antiquity, and which was particularly popular in Baroque times. They occur in many different variants: the labyrinth in the centre, the progressive labyrinth, labyrinths in the shape of a Pseudo-Venatius cross, rhomboidal letter labyrinth ${ }^{254}$. One of the most interesting examples of the labyrinth poem is the work of Venantius Fortunatus published in Carminum, epistolarum et expositionum libri... from $1603^{255}$. This labyrinth verse is arranged in the shape of a cross, and in its centre is the key word C R V X, which can be read in many different ways and which draws the whole text to the centre (it has, of course, a religious dimension):

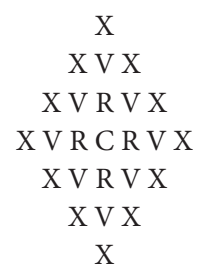

Another example is the labyrinth verse by Jan Karol Dachnowski and contained in his work Philantropia, Lubo Wiekom dtugo pamiętny dwoch nowych Małzonkow Związek... published in Cracow in $1631^{256}$. The poem is written in a book made for the occasion of the wedding of Łukasz Charmęski and Maryna Zolewska. The book opens with three interesting stemmata, and in the middle there is a labyrinth poem Kostká nowym małzonkom, which is a so-called labyrinth of the centre (see Illustration 7).

At the centre of the poem, written in capital letters is Z S A K V L V K A S Z (a mirror reflection of the name Łukasz, whose axis is the letter "L"). A monogram of the name Maryna is arranged in a rhombus shape in the text which contains the name Luke. Names of the spouses are repeated many times and can be read in many different ways. This is an example of occasional poetry, but very

254 P. Rypson, Piramidy, słońca, labirynty..., pp. 173-176.

255 V. Fortunatus, Venantii Honorii Clementiani Fortunati Carminum, epistolarum et expositionum libri XI Accessere Rhabani Mauri... poemata sacra, Moguncja 1617, p. 54, http://www.bsb-muenchen-digital.de/ web/web1068/bsb10685810/images/index. html? digID=bsb10685810\&pimage $=78 \& \mathrm{v}=$ pdf\&nav=0\&l=de (accessed: 9.06.2014).

256 K. Dachnowski, Philantropia, Lubo Wiekom długo pamiętny dwoch nowych Małzonkow Związek..., Cracow 1631, http://jbc.bj.uj.edu.pl/dlibra/doccontent? $\mathrm{id}=83642 \&$ from $=$ FBC (accessed: 9.06.2014). 
original, engaging the reader in a kind of game. Reading is linear and transversal at the same time; use is made of the mirror image effect of particular words written in the text. During reading, the sense of sight is thus engaged in a special way. Understanding the poetry system depends to a large extent on the perceptiveness of the reader drawn into the game based on the combination of letters and words - here the role of somatext is particularly highlighted. Upper- and lowercase letters are important because they form additional shapes to be seen in the text and which give the text extra meaning.

Illustration 7: K. Dachnowski, Philantropia, Lubo Wiekom dtugo pamiętny dwoch nowych Małzonkow Zwiazek..., Cracow 1631, p. 7, http://jbc.bj.uj.edu.pl/ dlibra/doccontent?id=83642\&from=FBC (accessed: 9.06.2014)

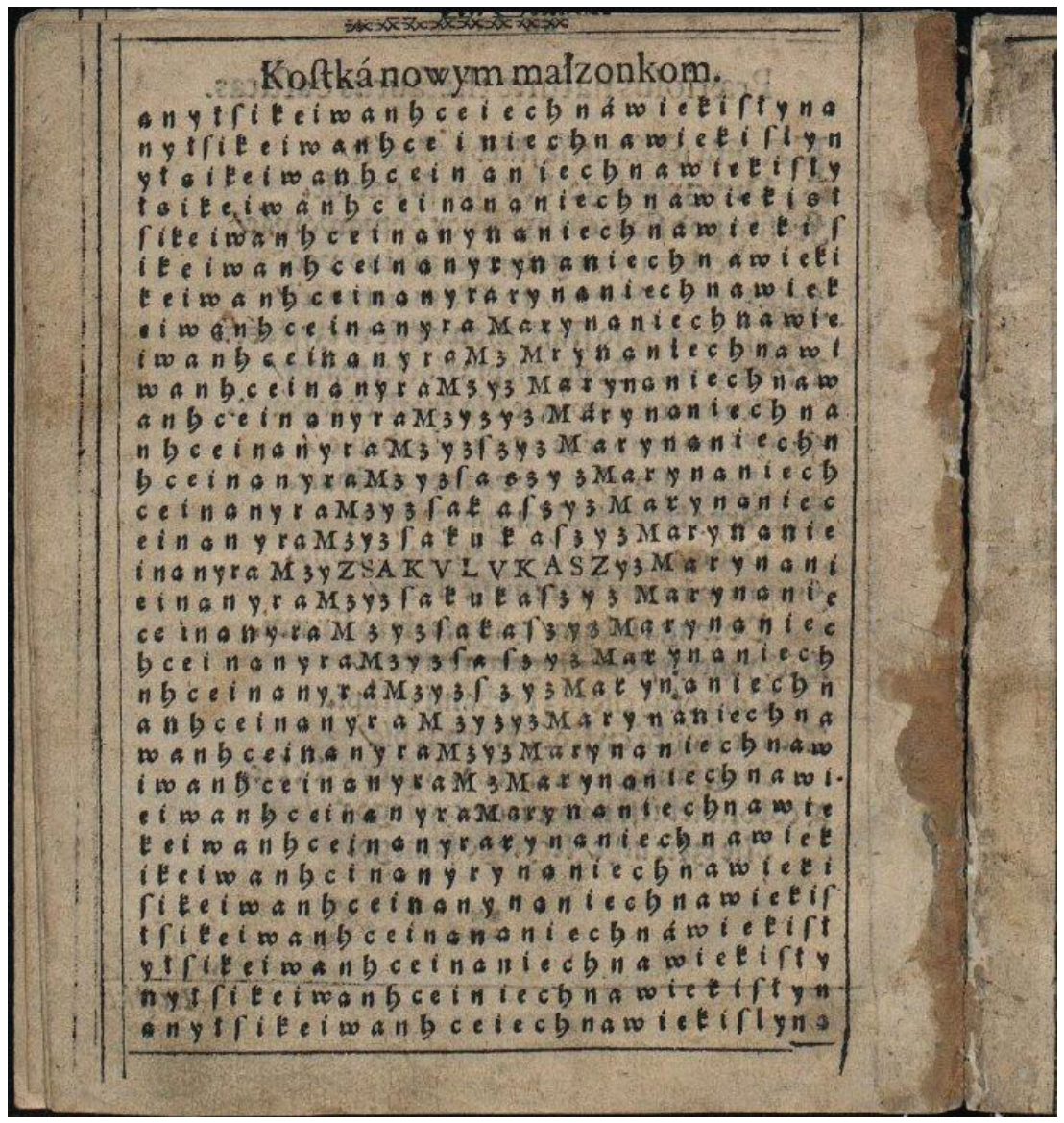


Still another example of visual poetry is carmen cancellatum - considered to have been created by Publilius Optatianus Porfirius (first half of the fourth century). Venantius Fortunatus, Hraban Maur and Erhard Cellius also cultivated this form of poetry. Amongst the Polish authors of pattern poetry are Stanisław Niegoszewski, Jan Racki, Maurycy Kiełkowski, Wawrzyniec Jan Będziński and many anonymous authors.

The name itself, carmina cancellata, comes from the characteristic features of the construction - this is about words or phrases woven into the main text that are reminiscent of the shape of trusses. In pattern poetry, word and image are inseparable. Their reading requires special intensity from the reader, because the meaning of the verse is encoded in the poem and form in a shape which is necessary to see. A pattern poem cannot just be read, it must be seen, saying literally: it is necessary to see the meaning of the poem. Reading is never linear, because in order to see the encrypted shape, the reader must read across, transversely (one needs to follow the letters that make up words and finally the form that gives the whole a supplementary or additional meaning). The pattern verse gains the value of a multiform text, which, formed by linearity and transversality together, and at the same time the sense of sight, is involved in a multifaceted reading.

In the Old Polish period pattern poetry took on very diverse characters: a pattern poem with mesostich, a shaped poem with intext or a pattern poem with intext in the form of a rebus ${ }^{257}$.

The complex character of the mode of reading these types of poems is clearly shown by one of the most famous Polish pattern poems by Stanisław Niegoszewski, written in Latin and published in the volume released by Aldo Manuzio ${ }^{258}$. The engraving contains poems written in the wings of St. Mark's lion, as well as a pattern poem centred on the image of a lion (see Illustration 8).

In a vertical layout, by reading the capital letters at the beginning, in the middle and at the end of each verse, we read: NICOLAO DEPONTE VENETORVM, next, within the text leading from the four corners meeting in the middle forming the word DUCIO shape the monogram Christus " $\mathrm{X}$ ", which very often appeared in pattern poetry:

257 P. Rypson, Piramidy, słońca, labirynty..., pp. 154-156.

258 A. Manuzio, Ut esset perpetuum Stanislai Nyegossewii [...] in nomen Venetum Pietatis argumentum, tum vero cum Aldo Mannucci dignum mutuae caritatis pignus [...], Venice 1584, http://www.dbc.wroc.pl/dlibra/doccontent?id=5614\&from=FBC (accessed: 9.06.2014). 
Illustration 8: A. Manuzio, Ut esset perpetuum Stanislai Nyegossewii [...] in nomen Venetum Pietatis argumentum, tum vero cum Aldo Mannucci dignum mutuae caritatis pignus [...], Venice 1584, p. 1, http://www.dbc.wroc.pl/ dlibra/doccontent?id=5614\&from=FBC (accessed: 9.06.2014)

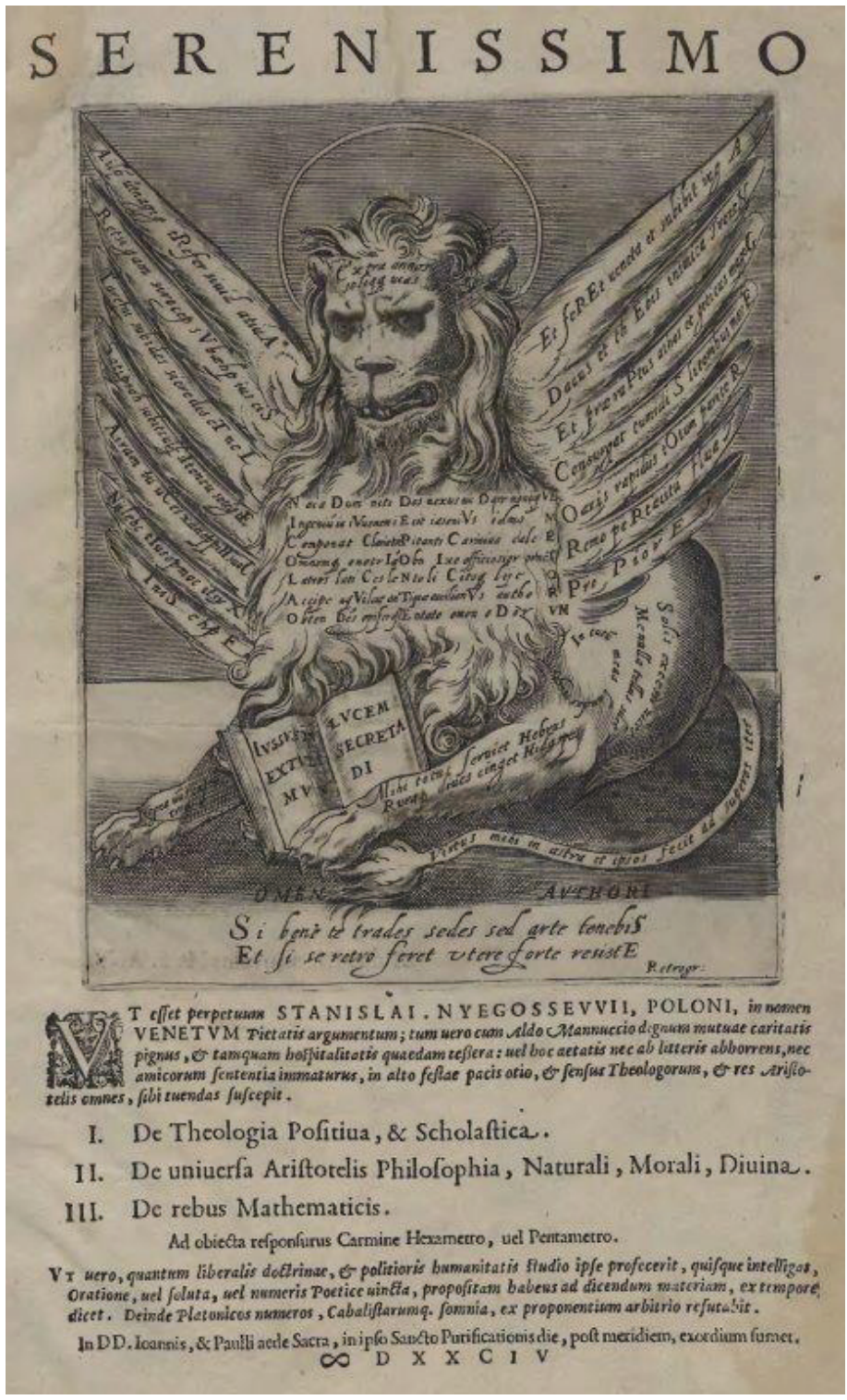




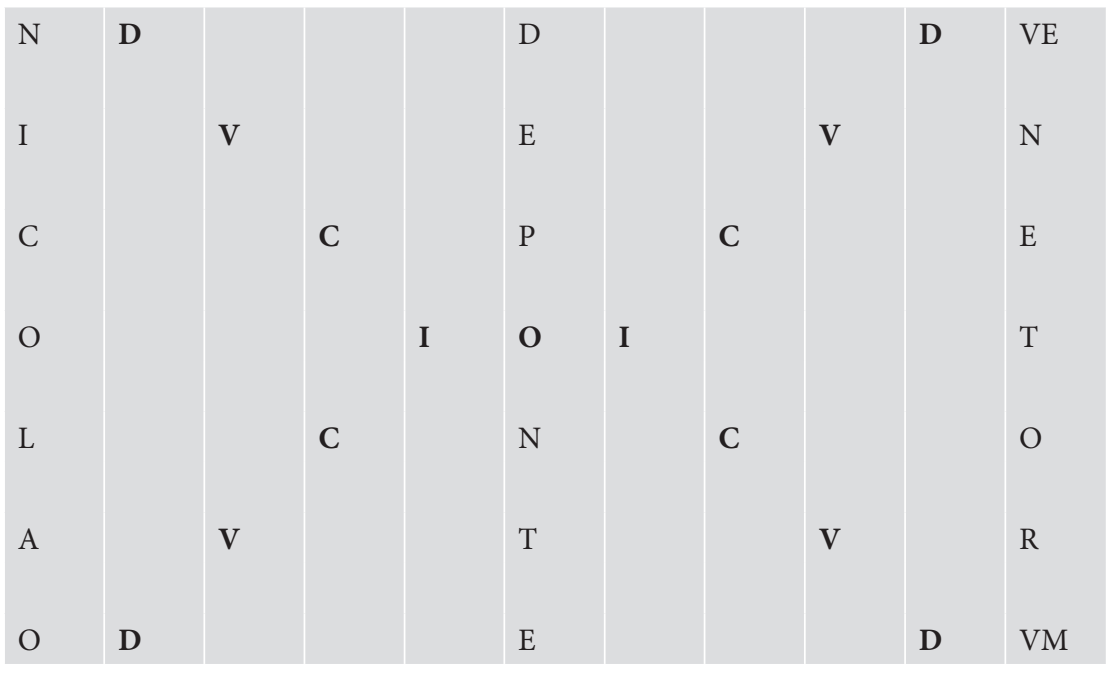

The poem should be read linearly, vertically and transversally, and from the whole emerges an additional and superior sense aided by the monogram. The text becomes a complex code, has a hidden secret which is revealed after a careful look.

Finally, the last example of visual poetry, which directly connects to the next subsection of this work. The French word calligramme combines in itself the Greek words kállos meaning 'beauty' and grámma, meaning 'letter' or 'inscription' Guillaume Apollinaire did not use this word to describe his poems at the very beginning, he called them vers figurés, poèmes idéogrammatiques (in English, use is also made of the name iconopoetic signs). He first used this description in 1918 when publishing the famous collection of poems Calligrammes. Poèmes de la paix et de la guerre 1913-1916 $6^{259}$ in „Mercure de France”. The form of these poems is closely connected with typography - the poem takes on the shape of objects or the various emotional states associated with them. Calligrams are in some way a reaction to the polycontextual nature of reality - to give it the right word, it was necessary to reach for innovative manners of expression. When Apollinaire's calligrams were first published, the poet was accused of epigonism, pointing out numerous earlier examples of pictorial lyrics. In fact, they had little in common with the old varieties of visual poetry and were original in the

259 The first calligrams were published in an edition of 200 numbered copies in August 1914. 
light of everything that had been done so far. To date, they have been identified with such lyrical forms as technopaegnia, carmina figurata, emblem and Figurgedicht ${ }^{260}$. Calligrams are usually defined in reference to works by Apollinaire ${ }^{261}$ or, more broadly, as a typical and proper phenomenon for avant-garde art, which combines various modes of artistic expression, aiming at a specific understanding of correspondence des arts $^{262}$. There are also works by Jean Cocteau, Pierre Albert-Birot, Kurt Schwitters, Filippo Marinetti, Tea van Doesburg, Tytus Czyżewski and Bruno Jasieński belonging to this concept of the calligram. Elements of calligrams also appear, for example in Semantic Divertissements by Franciszka and Stefan Themerson. Stephané Mallarmés Un coup de dés jamais nabolira le hasard ${ }^{263}$ is also often indicated as Apollinaire's inspiration; however, the calligram appears as a completely separate domain of typography.

In the case of calligrams, it is impossible to talk about the correspondence of the arts in the classical sense. Calligrams are looking for a variant of correspondence which would emphasise coexistence, the indivisible coexistence of phenomena arising from the order of natural and artificial signs. It also places emphasis, in particular, on the generation of images of senses written into various types of texts and the ways in which this generation functions.

One general rule about calligrams (and not only them, as this also concerns other forms of visual poetry) is that the graphic form of the text influences the shaping of the rhythm space. The rhythm of these texts combines temporality and spatiality - it is temporal (reading text) and spatial (reading the picture). Thanks to the coexistence of structures, the reader receives an open, polymorphic text, from which - due to an extremely dynamic rhythm - emanate significant forces intertwined with each other and coming from different orders of meaning, and thus strongly differentiated senses. Text layout on the

260 G. Gazda, [entry:] Kaligram, [in:] Słownik rodzajów i gatunków literackich..., pp. 331-332. See also G. Gazda, Architektonika graficzna poetyckiego utworu drukowanego, [in:] Literatura i metodologia. Konferencje teoretycznoliterackie w Spale i w Ustroniu, ed. J. Trzynadlowski, Wrocław 1970, pp. 215-227.

261 See M. Delaperrière, Polskie awangardy a poezja europejska, transl. A. Dziadek, Katowice 2004; G. Apollinaire, Calligrammes, transl. A. Hyde Greet, introduction S.I. Lockerbie, Berkeley 1980; P. Sacks-Galey, Calligramme ou écriture figurée, Paris 1988; P. Rypson, Obraz słowa. Historia poezji wizualnej, Warsaw 1989; W. Bohn, Modern Visual Poetry, Cranbury 2001.

262 G. Gazda, Kaligram..., p. 331.

263 S. Mallarmé, Rzut kośćmi nigdy nie zniesie przypadku, transl. T. Różycki, Cracow 2005. 
page becomes a representation and practice of speech. Figurativeness is significant, figurative text is at the same time linguistic and metalinguistic. The page becomes a "writing-reading scene" because it contains a trace of drawing and/ or image and writing. The reader of calligrams can never limit himself to reading just the text, which is anyhow still the case in many complex works. Critics point out their multifaceted nature, the simultaneity of the things they represent and their emotional states, and their strong dynamics. Calligrams take a very wide variety of forms, some are quite obvious, imitating and expressing an object (for example Apollinaire's Coeur Couronne Et Miroir $\left.{ }^{264}\right)$, sometimes more complex and requiring much more involvement of the reader's senses (for example Lettreocéan), which are needed to decrypt the text by reading subsequent fragments of the text and combining them together. The title Lettre-océan evokes certain ideas, associations and lines of thought, but without undertaking extensive reading, which involves deciphering (text is like a puzzle, a riddle) and linking successive elements, the text would be completely unreadable. Calligrams break with traditional linearity of text, though not entirely because some of them appear inside traditionally written and printed text (for example Apollinaire's $\mathrm{La}$ Petite Auto, Deuxième Canonnier conducteur), thus introducing a surprise to the reader based on the discontinuities of the text, as well as the radical change of rhythm. The characteristic feature of complex calligrams is transversality, which refers both to writing and the manner of reading, and this overrides the visual sense accustomed in traditional linear writing to an entirely different mode of perception and reading of words and their relationships.

\section{Polymorphic text - about the typographic work of the Themersons ${ }^{265}$}

The above-mentioned review of visual poetry was not included by chance and did not finish by chance with a calligram. What I would like to say about a certain area of Franciszka and Stefan Themerson's work starts, in turn, with calligrams. In 1968

264 G. Apollinaire, Serce korona i zwierciadło, transl. M. Żurowski, [in:] idem, Wybór pism, selection, introduction and notes provided by A. Ważyk, Warsaw 1980, p. 220.

265 In this chapter I make use of works published earlier: A. Dziadek, Themerson $i$ Schwitters, „Teksty Drugie” 2006, No. 4, pp. 85-93; A. Dziadek, Tekst wielowymiarowy przypadek „Semantic Divertissements” Franciszki i Stefana Themersonów, „Przegląd Kulturoznawczy" 2009, No. 5, pp. 57-64. For the purposes of this discourse they have been modified and adapted to the specific theoretical assumptions. 
Stefan Themerson published Apollinaire's Lyrical Ideograms ${ }^{266}$ - this was one of the Themersons' most important works published by the London publishing house Gaberbbochus. This is not a simple presentation of Apollinaire's calligrams but a heterogeneous "third form", which combines texts and images, and which contains a treatise on the sign (also about the ideogram and symbol), and begins not so much as an attempt to define it, as an indication of the difficulty with its definition. This is also a lecture on visual poetry (many references here to its history and its authors - there are reproductions of the famous $\mathrm{La}$ Bouteille by CharlesFrançois Panard and Herbert's Easter Wings); there is also a history of calligrams, a report of a conversation with the poet and typographer Pierre Albert-Birot, who edited Apollinaire's texts. There are also reproductions of calligram manuscripts, alongside printed calligrams, and so texts which have undergone typographic operations, but this is not just about printing technique, since typographic art is the interpretation of handwritten text. Being honest, Apollinaire's calligrams would have to be published in just such a way - on the one hand, they are text-drawings, on which one can see a trace of a hand, a trace of a body, a mark on a page with text, and on the other hand, a display of typographic art which must reshape a difficult manuscript into a printed text (see Illustration 9).

Themerson rightly claims that calligrams can be read aloud - the reading actually begins with the picture which is like the first level of somatic experience, and only then comes the rhythm of the poetic text.

This is not the only book devoted to the outstanding creator that Themerson prepared, and not the only one that discusses the works in such an unconventional way, using words and various forms of images (sketches, pictures, collages), whose reading depends on the combination of Text and Somatext. In the Themersons' output there are two works devoted to Kurt Schwitters (more about this later), there is also a work devoted to Jankel Adler - Jankel Adler. An artist seen from one of many possible angles ${ }^{267}$ - a book in which Adler's text and drawings coexist specifically for the purpose of this extraordinary edition, and moreover - printed on handmade paper, which has an essential significance from the point of view of Somatext, as the sense of touch is also active in the reading process - the rough texture of the paper, its granularity, which further stimulates the senses and strengthens the somatic experience of the reader.

266 S. Themerson, Apollinaire's lyrical ideograms, London 1968.

267 S. Themerson, Jankel Adler. An artist seen from one of many possible angles. With twelve full page drawings by Jankel Adler, London 1948. 
Illustration 9: S. Themerson, Apollinaire's lyrical ideograms, London 1968, p. 36.
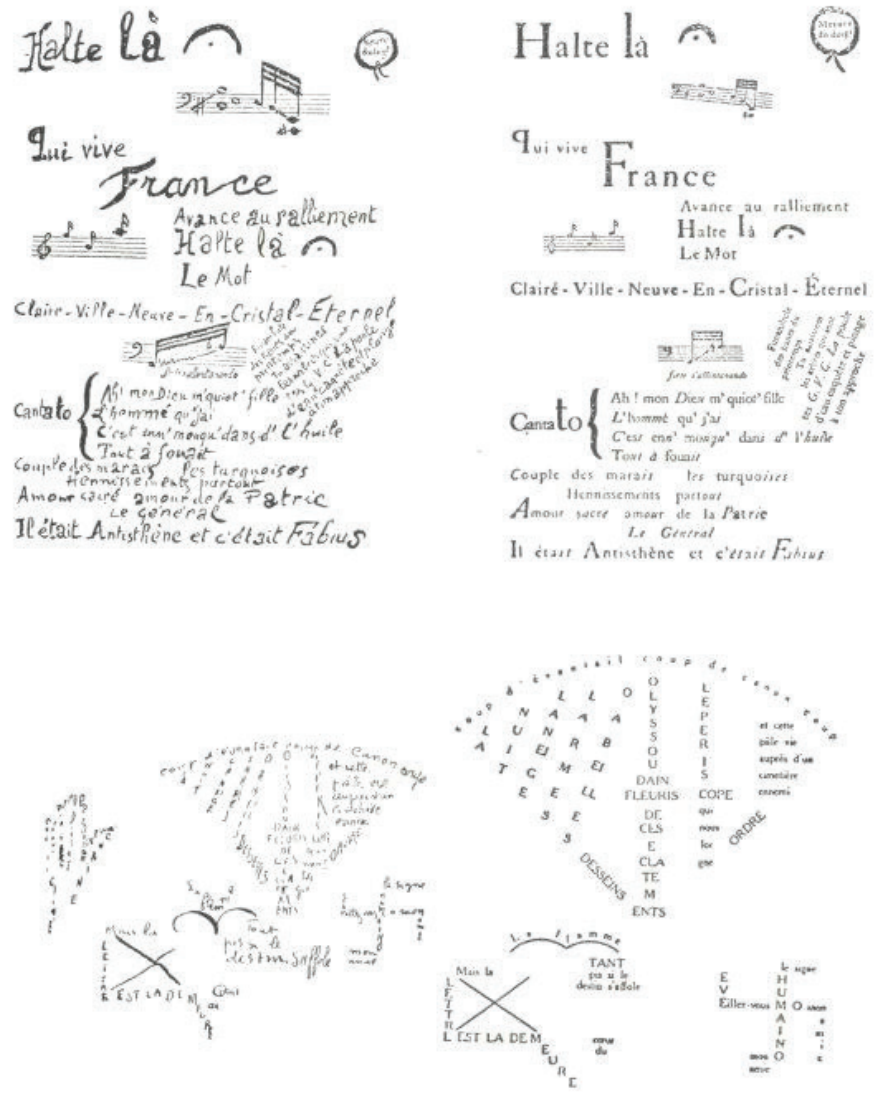

Before we look more closely at the books devoted to Schwitters, it is necessary to briefly recall the history of their acquaintance. Themerson met Schwitters in London during the Second World War. The period of their acquaintance indeed very important - dates from 1943 to 1948. Both artists met in extraordinary circumstances, for it was the solemn meeting of the PEN Club in London in 1943 dedicated to the three hundredth anniversary of the publication of John Milton's Areopagitica. Themerson recalls: 
Since I first met him, whenever I hear his name, [...]

it is always closely followed in my mind by another name the name of another man,

and if

I tell you the other name now, you may say I am committing a heresy. [...]

well, the name so heretically associated in my mind with the name of

Kurt Schwitters, is: John Milton. ${ }^{268}$

Both artists were invited to the ceremonial sitting at the PEN Club and were seated side by side. Schwitters had a habit of collecting various strange objects that seemed interesting to him, and he did so on this occasion. On the way to the French Institute, where the meeting was to take place, he walked past a bombed building and pulled a piece of wire from the rubble, which he began to lay out in a space sculpture during the session. The celebrated writers thought that an electrician or plumber had accidentally entered the meeting room. However, this was not a mistake, and the sculpture, called Air and wire sculpture, ended up in Lord's Gallery.

Milton's Areopagitica is one of the most famous texts written in defence of the word, the word which is rebellious against every act of censorship violence committed to works of art and literary works. Paradise Lost is also connected to the rebellion against rhymed verse, against the imposed restrictions which become for the poet "anguish and doubt and fear" and is "the invention of a barbarous age, to set off wretched matter and lame metre"269.

Milton's revolutionary gesture was repeated in a singular way by Ursonate, and Schwitters' decision to speak freely forced him to leave Germany because it was contrary to the Nazi ordnung. Recalling Schwitters' fate, Themerson refers to Kandinski's words: "Nothing, nothing is resisted with such savagery as a new form in art" ${ }^{\prime 270}$. And indeed, it is necessary to admit that the originality and unconventionality of the word "Merz" (formed, as we recall, from the press release of KOMMERZ UND PRIVAT BANK by cutting off the first syllable of the word KOMMERZ), used to describe Schwitters' writings, paintings and structures, clashed fundamentally with the rules imposed in all areas of life by the System, which is after all usually the enemy of the arts and all artistic activity of mankind. In the case of Schwitters, as with many other avant-garde creators (and also Themerson), the strong influence of the anarchic element was revealed, which struck with all force in the binary opposites of proper/improper, norm/ deviation, rational/irrational, and trying to shake those opposites, was against what philosophy would define in the twentieth century as phallogocentrism

268 S. Themerson, Kurt Schwitters in England, London 1958, p. 9.

269 J. Milton, Paradise Lost. Oxford University Press, Oxford 2005, p. 11.

270 S. Themerson, Kurt Schwitters in England, op. cit., p. 14. 
unambiguously associated with various forms of power. Stefan Themerson, as author of Wykładów profesora Mama knew very well about this (it is true he did not know the word "phallogocentrism” and never used it, but I believe he would have been happy to accept it).

For Themerson the revolutionary aspect of Schwitters' work - to say pathetically - had a universal and timeless character. Themerson discovered that this had the same force in the twenties when it came into being, in the nineteen forties when they met and in the sixties when he wrote a book about it. It remains to be stated that the power hidden in this extraordinary work remains active to this day and continues to act in the same way. One of the most important questions taken by the avant-garde artists concerns the human condition in the modern world (questions about identity, its internal and external constraints), the question of the condition of man trying to get out, in the words of Raoul Hausmann, from chaoplasma (the term from "simultangedicht” was published in "Merz” No. 4 in July 1923). The avant-gardists went far ahead of their epoch and raised important questions also relevant today in the postmodern era.

Each of the books devoted to Schwitters is a kind of tribute paid to the artist by the artist. The first work about the creator of "Merz” was Kurt Schwitters in England published by Gaberbocchus Press in 1958 and based on a lecture given in Gaberbocchus Common Room (25 February 1958; Kurt Schwitters' Last Notebook). A few years later Themerson gave a lecture for the Society of Arts in Cambridge (17 February 1961), which later became the basis for the beautiful edition of Kurt Schwitters on a time chart, published in the journal „Typographica", No. 16 (December 1967).

To these two editions it is necessary to add the book PIN and the Story of PIN by Kurt Schwitters and Raoul Hausmann, which was published by Gaberbocchus Press in $1962^{271}$ - it contained the history of the friendship of the two artists, which started in 1918, their poems, fragments of co-written texts, photograms and photomontage by Hausmann and Schwitters' collage. It is also a story of friendship and a story of a shared idea of two artists wishing to undertake an innovative idea of poetry known by the abbreviation PIN (this abbreviation can be expanded in several different ways: Poetry Is Now, Présence Inter New, Poetry Intervenes New, Present Inter Noumenal) in the form of a magazine. Their idea was born in 1946, but it was not realised until 1962, when the Themerson publishing house brought out PIN.

271 Kurt Schwitters, Raoul Hausmann and the story of PIN, introduction J. Reichardt, project A. Lovell, London 1962. 
In creating Kurt Schwitters in England and writing about the fate of the German artist, Themerson wrote partly about himself. It happened here, in these seemingly alien identities, the fate of these two individual autarkies overlap and penetrate each other - the similarities seem quite obvious. On the one hand, the two artists were avant-garde creators, multifaceted creators, open to a variety of means of artistic expression. Themerson created "semantic poetry", which was his own invention, and his pioneering work in this field has received international recognition ${ }^{272}$; his novels and essays were translated into many languages; together with his wife Franciszka, he was one of the most interesting avant-garde filmmakers and also an original editor. On the other hand, both - though for various reasons - became artists in a foreign country and in a foreign language. Themerson left Poland with his wife in 1938 to Paris, after the outbreak of war he joined the Polish army and from 1942 lived in England permanently, as did many other Polish writers and artists (London during the war and after 1945 became one of the strongest centres of Polish political emigration). It should be noted here that Themerson for many reasons did not identify himself with the Polish emigration community, assuming rather the status of a Polish writer abroad creating in many languages. On the other hand, for Schwitters - as avant-garde artist - he could not have a place in fascist Germany; the situation in which he found himself first in Norway and later in Great Britain was a situation of forced emigration. This affinity for the person afflicted by fate perhaps decided on Themerson's particular fascination with Schwitters. Speaking about the author of An Anna Blume, he talked about Dada's movement, his historical, political and artistic background, but with admiration and respect he placed Schwitters himself as a unique and unrepeatable creator in the foreground. $\mathrm{He}$ adapted this to his own will, in telling Themerson the story of the invention of the word „Merz", Schwitters clearly indicated that „Dada people were friends. But Merz was independent. Merz was mine. Dada was everybody's" ${ }^{\prime 273}$. Themerson also pointed out the special situation of forced alienation in which the then unknown German artist found himself in England (during his stay in England he had only one exhibition organised in 1944 at Bilbo's Gallery by Herbert Read and two "Merz recitals" in London Gallery in 1947). This alienation was not only due to the fact that in England he was an unknown artist, but also because he

272 In the fragment written by Raymond Queneau La littérature définitionnelle of the Oulipo book, La littérature potentielle... (p. 115) Themerson together with his idea of "semantic literature" was recognised as a precursor to the thinking of Géorges Perec and Queneau himself.

273 S. Themerson, Kurt Schwitters on a time chart, „Typographica” 1967, No. 16. 
was in England during the war and as a German, was burdened with anathema. In the consciousness of the average British citizen, a German in England during the war could only be a camouflaged Nazi, just as a Jew who was not a German could only be a Communist - which is of course a stereotype which could appear with particular strength in the situation of war. The problem had to be more serious for Schwitters, for he belonged to the category of artists who have a hard time understanding classifications based on circularity and do not succumb to systemic, simplified rules of thinking. Like Themerson was also one of those who knew perfectly well the ideological implications of the twentieth century and tried to refute them consistently, it is in this field that the special mental strength and spiritual similarity of both artists are revealed.

This book is finally closed with texts written in English, which Themerson chose from Schwitters's notebook. Here are a few of them:

When I am talking about the weather

When I am talking about the weather,

I know what I am talking about. ${ }^{274}$

\section{I build my time}

I build my time

In gathering flowers

And throwing out the weeds.

I build my time

In gathering fruits

And throwing out all that is bad

And old and rotten.

This time will lead me forward

To death

And God

And Paradise. ${ }^{275}$

At first men were limited

At first men were limited,

limited,

limited,

Until they imited, imited,

274 S. Themerson, Kurt Schwitters in England..., p. 47.

275 Ibidem, p. 52. 
imited,

But when they imited,

imited,

imitated,

Still they remained limited,

limited,

limited.

\subsubsection{7}

Themerson did something similar in the case of Kurt Schwitters on a time chart, placing Schwitters on the time chart; remembering their unusual first meeting, he reminded us that the first number of "Merz" was published in Hanover in 1923 and in the same time Adolf Hitler's Mein Kampf was written. This second book devoted to Schwitters appeared, as I have already mentioned, from a lecture that probably seemed inadequate and incomprehensible to Themerson. When the manuscript of that lecture from years ago is read along with the final printed version of Kurt Schwitters on a time chart, it is easy to see some similarities, but in fact these two presentations about Schwitters are diametrically different, especially as the latter becomes an original, pulsating, Text of many shades of meaning. Writing the word "Text" with a capital letter was a deliberate choice, which I will further attempt to explain.

On account of the combination of different sign systems, reading Themerson's books about Schwitters could be undertaken along the lines of intersemiotic studies ${ }^{276}$. It seems to me, however, that such an approach may be insufficient; moreover - it is even very restrictive, and probably Themerson would have been opposed to such an approach. To determine the mode of reading, some possible way of reading, it is worth referring to the work of Roland Barthes. According to his valid justifications, traditional semiotics dealt with heteroclitic constructions (pictures, myths, stories) and tried to construct a Model in which every artistic creation could be defined in terms of deviation ${ }^{277}$. In adopting the semiotic mode of reading, it is necessary in this case to go beyond the traditional way of thinking in terms of Model, Norm, Code and Law, that is to say theological terms. It is worth placing emphasis not so much on the structure as on the structuring (in the manner it is made, in the way it operates), not so much on the Model as on the work of

276 Compare, for example, A. Pruszyński, O grach intersemiotycznych Stefana Themersona, [in:] Archiwum Themersonów w Polsce, ed. A. Dziadek, D. Rott, Katowice 2003, pp. 33-74. See also A. Pruszyński, Dobre maniery Stefana Themersona, Gdańsk 2005.

277 R. Barthes, La peinture est-elle un langage?, [in:] idem, Oeuvres complètes, vol. 3, Paris 2002, p. 99. 
the system. It is worth the temptation to reject the hermeneutical search for truth, some secret hidden in the texts, and to seek rather the action through which these texts are structured - thus the work of reading could be identified with the work of writing. The task for the readers of Themerson's books, which undoubtedly are artistic works and at the same time an unquestionable and untypical testimony, is thus writing a text about Kurt Schwitters.

Taking a careful look at these typographic works, it must be unequivocally clear that they were never intended for any "intersemiotic play", nothing which could be considered simply as an exchange of signs between systems (I place emphasis here on the economic value of meaning the word "exchange"). Speaking of "intersemiotic play", the distinctness of meaning systems is presumed, and in Themerson's books this is first and foremost about their coexistence. Ewa Kraskowska's description in this regard when writing about Themerson's artistic activities (including typographic) is particularly accurate; she speaks of "multiple coding as a creative method"278. No matter how we try to name the practices associated with editing these books, one thing is certain: Text and Somatext are inseparable in them.

The pages of this book function like the previously mentioned pages performatives. Here, however, the matter is much more complicated. In their atypical and unusual nature, the whole complex intratypographic and intertextual network forms an open text not sympathetic to the System and traditional reading based on and protected by that System. From the assumptions they expect an active role from the reader in creating the text, forcing them to break in some way the schematic predictability, confirmed indeed through even just the handwritten formula and printed in red: "This space, reader, for you to fill with whatever you consider relevant", which we find in Kurt Schwitters on a time chart (see Illustration 10).

The book about Schwitters is reminiscent in shape of a collage. The pages of Kurt Schwitters in England are printed on white paper (main text) and yellow and blue (Schwitters' text). Apart from the unconventional and non-linearly arranged texts, the book also contains photographs (for example the picture of the wall in the famous, third Merzbarn, in Ambleside), a reproduction of Schwitters' collage work (Illustration 11 presents a collage made by Schwitters in the workshop of Franciszka Themerson in 1944), photos of his sculptures, works written

278 E. Kraskowska, Twórczość Stefana Themersona. Dwujęzyczność a literatura, Wrocław 1989, pp. 110-126. 
Illustration 10: S. Themerson, Kurt Schwitters on a time chart.., p. 25.

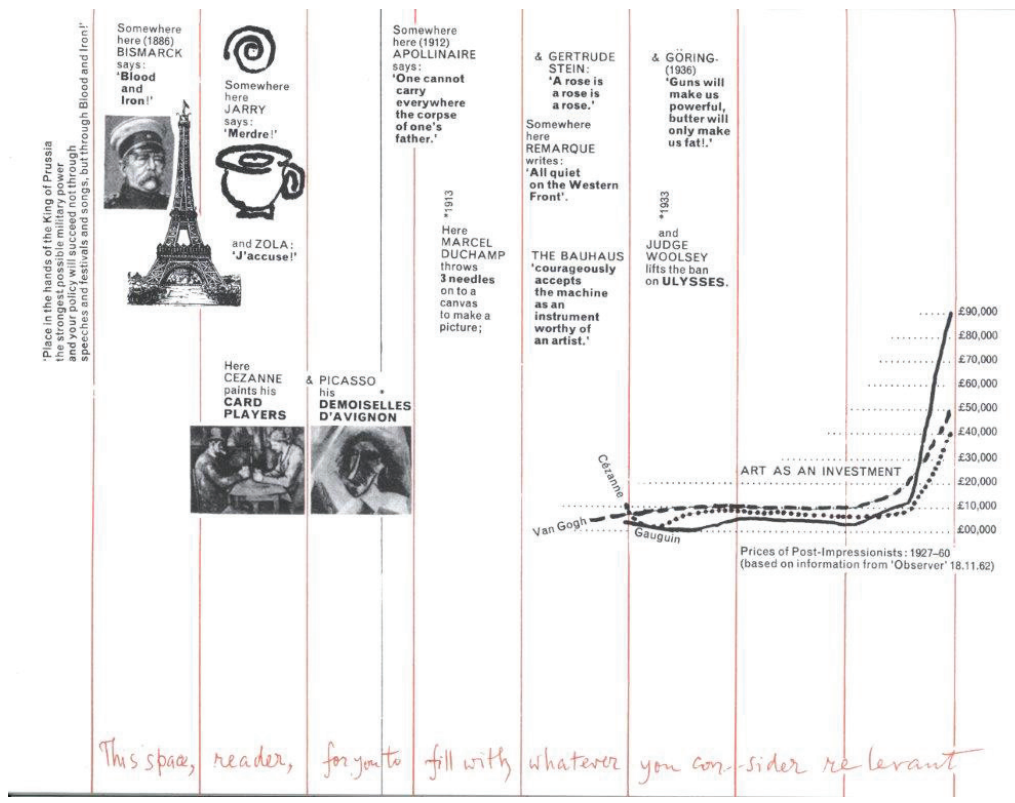

by him in England and reprinted pages from the artist's last notebook in English, a reprint of Ursonate and a photographic record of Schwitters' mouth reciting his famous work. The issue of reciting this work seems particularly important. Schwitters recited it in a remarkable way, breathed life into this incredible text and made it an authentic sonata of ambiguous sounds ${ }^{279}$. In a certain fragment of the book Themerson recalls that at one of the "Merz poetry recitals", organised in London in 1947 by the Belgian surrealist Edouard Léon Théodore Mesens, two men from the $\mathrm{BBC}$ appeared, who intended to make recordings of Ursonate. Schwitters began to read his work, and the gentlemen left the room half way through the recitation. Themerson - quite the opposite - with absolute certainty was able to appreciate the importance of the recitation of phonetic poetry (one could even say the performance) of this work, during which the artist is like a body, and having no other possibility to include in the text, decided to attach photographs with random depictions of the artist's mouth - these pictures became somatic metaphors of sound poetry.

279 A recitation of Schwitters' work can be heard in an interesting album release lunapark 0,10 prepared by Marc Dachy for publishing house Subrosa in 1999. 
Illustration 11: S. Themerson, Kurt Schwitters in England..., p. 29. A picture of a collage by Schwitters during a stay at the Themersons' house in London in 1944.

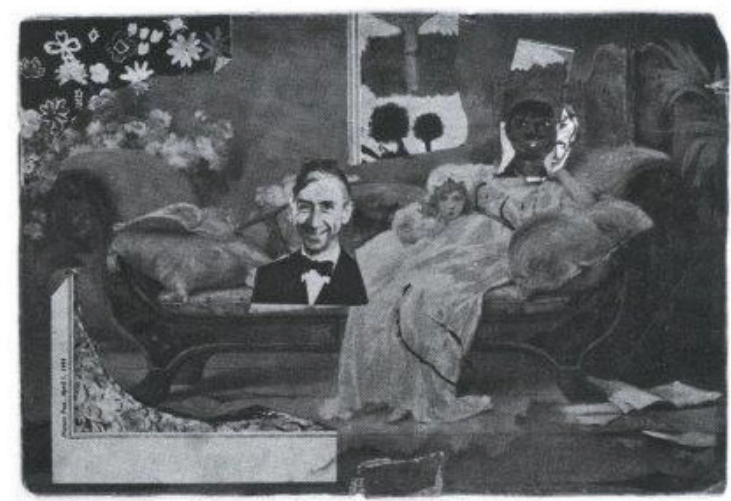

Kurt Schwitters did this collage (with Herbert Read's photograph eut out of a capy of Pictare Port) on the spur of the moment in Francisza. Themenon's studio in London in 1944, from odd bits found in the corners,

As for Kurt Schwitters on a time chart, it must be admitted that it is like real patchwork that forces the reader to stitch together, combine scattered sentences, sketches, different types of fonts and typographically reproduced writing, various icons and red lines of dates vertically arranged on the page (like meridians). The reader's memory and knowledge, having signs scattered over the pages, become a kind of techné, as if a machine, and at the same time a craft, the practice of producing this text about Schwitters. The book opens up a schematic and unformed image of two world hemispheres; through one of them runs a red meridian, on the meridian is placed a red dot in the place where London is on the map of the world, and under the sketch there is the caption "I met him in 1943, in London", next to which we find photographs by Themerson and Schwitters (see Illustration 12). 
Illustration 12: S. Themerson, Kurt Schwitters on a time chart..., p. 21. Themerson's and Schwitters' pictures placed next to each other.

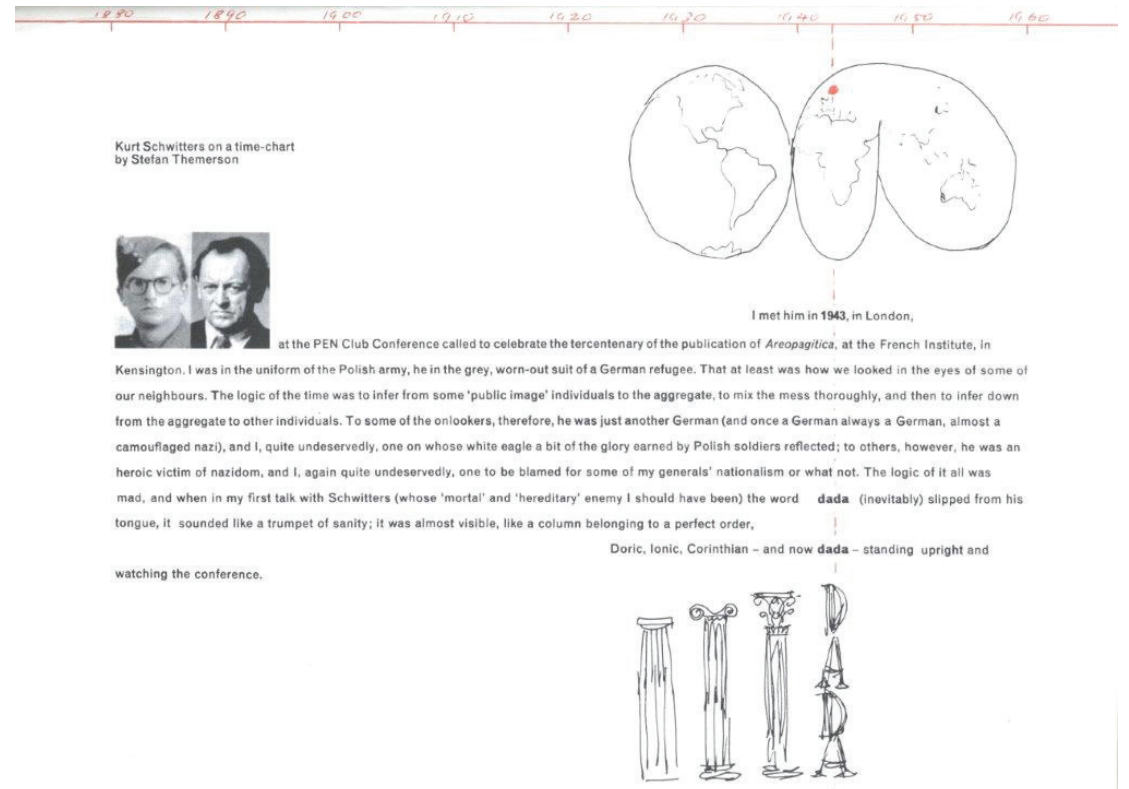

This particular book can be read as a patchwork whose loosely connected, diffuse fragments have in themselves the special power to generate additional meanings, based on each of which one could build a comprehensive narrative that would delve into the recesses of the past century's history (the Victorian period called up by photographs of the queen, the First and Second World War, Paul Cézanne's and Pablo Picasso's paintings, reproductions of Schwitters' works, photographs of atomic bomb explosions, quotations from Hugo Ball and Richard Huelsenbeck). This includes both collective history and single history, and it is this which seems to be the most important from Themerson's point of view. Thanks to the patchwork structure, the reader receives a polymorphic, open text, from which - due to the extremely dynamic rhythm of images - emanates a great force interwoven with itself, coming from different layers of meaning, and thus strongly differentiated senses.

Here we have a special case of interference and coexistence of words and images, Text and Somatext, which are subject to constant movement. In the resulting text, autobiography, biographies, existential and artistic experiences all combine with the 
whole rich space of trails and signs. The text associated with the Somatext in fact never ends (the last page of the book is a grid of red lines, so the story told by Themerson also seems endless), is shifted to infinity, and words and images do not so much express some encrypted code but rather expose the coding work itself. This means that there is no ready-made system, because the first priority becomes generation of the system. Themerson's patchwork is laid out in as a text without a centre where traditional linearity cannot be found, and in which it is necessary in some places to be read in different directions (literally and figuratively, since sometimes it is necessary to turn the book around to read a given fragment), and return to previous pages, and sometimes it is even needed to make sure everything has been read.

Another outstanding literary and editorial work by the Themersons in which Text and Somatext are inextricably intertwined is Semantic Divertissements ${ }^{280}$. The space in this edition was created through the printed page on which natural signs (Franciszka's sketches) and artificial signs (Stefan's text) link together and coexist. Two character systems, two modes of meaning, come into a relationship of coexistence and interference. Semantic Divertissements in their whole typographic-text work is not an isolated case. Indeed it must be clearly stated that these form a stage in the Themersons' creative journey, a stage of subsequent discoveries and explorations in the art of word, image and sound, which eventually led the Themersons to such a remarkable work as the famous semantic opera St. Francis and the Wolf of $\mathrm{Gubbio}^{281}$, where semantics cannot be reduced only to the meanings of words.

Writing about the Themersons' texts, I quite consciously avoid the word experiment, which - in my opinion - generally, does not suit the work of these outstanding artists, just like other labels tagged onto them by critics (avant-garde, poetics of the absurd, etc.). The experiment determines something that is in the phase of processing, preparation, unfinished, or in an untouched state. In the meantime, works created jointly by the Themersons are always polished in the smallest details and constitute thoroughly thought-through compositions, and each of them is one of the stages leading to the creation of the perfect "polymorphic text".

280 F. Themerson and S. Themerson, Semantic Divertissements, London 1962.

281 F. Themerson and S. Themerson, St. Francis and the Wolf of Gubbio or Brother Francis' Lamb Chops. An Opera in 2 Acts, Amsterdam-London 1972. A fundamental comparative analysis of this work was recently undertaken by Andrzej Hejmej, Estetyka intermedialności Stefana Themersona ("St. Francis \& The Wolf of Gubbio or Brother Francis' Lamb Chops”), „Pamiętnik Literacki” 2011, No. 3, pp. 55-76, reprint in: A. Hejmej, Komparatystyka. Studia literackie - studia kulturowe, Cracow 2013, pp. 153-187. 
Polymorphic text completely annuls disputes about the superiority of the word over the image or vice versa. In the famous manifesto The urge to create visions we read these words, amongst other things:

It would be absurd to say that Gutenberg built the foundations of poetry. It is equally wrong to think that the art of the cinema was born with Edison or Lumiere. Poetry, long before we found a way of preserving it in written or printed characters, was recorded in human memory. Visions, long before we found a way of developing them in cinema film, were recorded in poetry. ${ }^{282}$

Polymorphic text rather looks for a variant of correspondence that would emphasise coexistence, the indissoluble coexistence of forms arising from the order of natural and artificial signs. It places emphasis in particular on the issue of generating meanings through images in various types of texts and the ways in which this generation functions.

In attempting to describe the specifics of Semantic Divertissements, I used the words "coexistence" and "interference". Particularly the latter seems especially important. They could be complemented by the addition of the word "oscillation". Here I would like to draw attention to the fact that in recent years, the relationships between images and texts have often been described using metaphors taken from physics (probably not accidental - object and body), although they are not entirely borrowed exclusively from this scientific discipline ${ }^{283}$. Probably there is no chance in this case, because the matter is about the object sending the signs and the subject which is the product of these. The word "interference" refers to the overlapping of light or sound of the same frequency, which results in an increase or decrease in the intensity of the resulting wave. So, as a metaphor for determining the relationship between written text and image, it is extremely accurate in this case.

Jean-Luc Nancy in his book titled Au fond des images ${ }^{284}$ proposes the term "oscillation" to determine the interdependence between images and texts; in physics this means oscillatory motion, wave, vibration, and in its figurative sense means going between two given possibilities (this or that), leaning towards one or the other possibility (which is governed by logic: this or the other, but neither this nor that, which means a position of suspension between, without the necessity to choose one of the given possibilities). Nancy delineates the word "oscillation" with the help of the adjective "clear" (loscillation distincte) and ultimately establishes the

282 S. Themerson, The urge to create visions. Gaberbocchus Press, London 1983, p. 12.

283 Compare, for example M.A. Caws, The Art of Interference, Princeton 1990, and also: J.-L. Nancy, Au fond des images...

284 J.-L. Nancy, Au fond des images... 
relationship between the image and the text based on separateness and simultaneous approach to one another. Also, this idea of the relationship between the Text and the Somatext appears to be particularly useful at the moment when we try to describe the work of the Themersons.

When reading this text, it is necessary to look for the activity through which it is structured - this way of reading the work can be identified with the work of writing it. Ascertaining "the work of writing" is here strongly justified, that this is not just about the part authored by Stefan, printed in the form written using a typewriter and the appropriately shaped text (already this in itself carries value as an image), but also about the sketches by Franciszka, and their simple, expressive line which somewhat approaches writing. The task for the reader of books by the Themersons, which is undoubtedly an artistic product and at the same time an unquestionable and atypical creative testimony, is to write a completely new text (see Illustration 13).

Illustration 13: F. Themerson and S. Themerson, Semantic Divertissements..., p. 1.

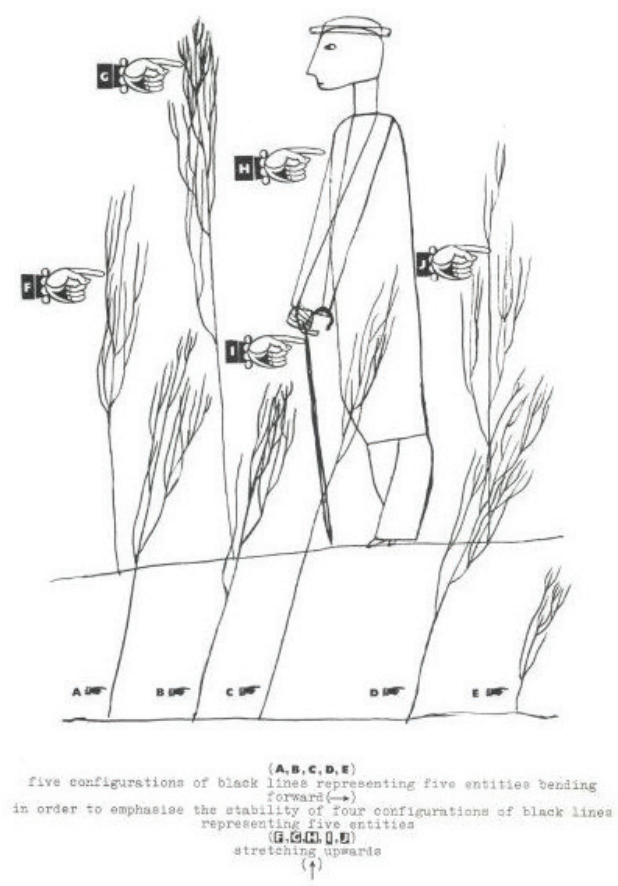


Various graphic forms influence the shaping of the rhythm space. The page layout becomes a representation and a speech practice. Figurativeness is significant, as the figurative text is simultaneously linguistic and extra-linguistic. Semantic Divertissements in this regard is not some individual example in the case of Stefan's creative work, as we can recall, for example the poem Wariacje na temat from 1946 or also Wiersze dla dzieci, a przed starzeniem się przestroga from $1942^{285}$.

Semantic Divertissements is governed by the rule of conjuncture - this is about the close relationship between words and images. It is an unusual creation, original, pulsating in many tones and shades, in which Stefan's words intertwine with the unique, easily recognisable lines of Franciszka's drawings, to finally form a coherent whole, which, however, presents significant difficulties in reading.

In principle everything here is simple, described in detail by a legend (uppercase and lowercase letters of the alphabet additionally indicated with bold print, arrows, explanations in parentheses; all of this contributes to an entire rich intratypographic network that further enhances the meaning of the whole text), indicated with the help of a sketch of the palm of a hand with the index finger extended, which is a deictic gesture intended to reassure the reader as to the meaning of each drawing in such a way that there is absolutely no uncertainty. The drawings, like the descriptive texts, are in principle amusing, somewhat perverse, saturated in irony, which inevitably leads to reverie and reflection.

However, the difficulty of reading this work begins at the level of translation of the title Semantic Divertissements. As far as the word "semantic" does not give rise to any doubts, the word "divertissement" leads us to a game of many meanings. This is because it could perhaps be "semantic variety", "semantic games" or "semantic entertainment" (in the sense of interruptions during theatrical spectacles, interrupting the attention of the audience watching the show). In principle, they are supposed to be something trivial, insignificant, funny and ephemeral at the same time. But are they really? Can they be, since the title of the first of them, Man is a reed constitutes a clear reference to Blaise Pascal's Pensées (concerning fragments 347 and 348; to remind ourselves the first one sounds: "A human being is only a reed, the weakest in nature, but he is a thinking reed"286). This is probably one of the most philosophical quotes we could meet. The quotation is often referred to, but is it thought through or understood (Themerson would not be himself if he did not ask such questions)? This is exactly why Pascal's

285 Compare S. Themerson, Wiersze wybrane, foreword, selection and compilation J. Reichardt, Katowice 2003, pp. 137-138 and 155-168.

286 B. Pascal, Pensées and Other Writings, transl. Honor Levi, introduction Anthony Levi, Oxford 1999, p. 72. 
words remain broken, suspended in a vacuum. The reader will be able to say them throughout the reading of the entire text and ultimately redefine the concept of man. Indeed, redefine, because this is exactly what this startling work is about. Also, the titles of other fragments refer to various philosophical intertexts: Past \& Future, Life \& Death and ultimately, we are dealing here not only with some sort of casual entertainment, but rather with a philosophical poem. Several other fragments, Kneeling, Souls and also More Souls, are laid out as a parody of a theological treatise. The explanation from the sixteenth part, closing the whole piece, is worth mentioning here:

Five theologically immortal substances coming back from Heaven to inhabit five human bodies that have been born on Earth during the $2 \frac{1}{2}$ seconds you have been reading these words. ${ }^{287}$

Indeed, here we are dealing with a parody of a theological treatise, as argued in the tenth fragment, A few samples of catarrhines, in which the subject of reference is Peep of Day, and therefore a family religious aid, or also a guidebook to the Bible ${ }^{288}$ (below the text there is a footnote which states: "With acknowledgements to The Peep of Day").

At this point, it would be legitimate to ask about the genological status of Semantic Divertissements. From one side "divertissements" is an entertaining dramatic intermedia, and I also indicated the connection with a philosophical poem. The visual aspects (legends, the deictic hand gesture, explanations indicated in alphabetical order somewhat like a text book, or guide) testify to the didactic, sketchy character of the text, that lectures, teaches. However, this work is also of a metalinguistic character, I would say, is a linguistic treatise, confirmed by the references to dictionaries (for example in the seventh part to the Shorter Oxford English Dictionary, and in the eleventh part to the Dictionary of Biology, which was needed to clarify the word "catarrhines", as the zoological name signifying the species of simians; in essence, this is a description of a man who differs from other catarrhini species through anatomical features and behaviour). The careful reader of Themerson can without difficulty find traces of the semantic poetry invented by the writer based on the writing of definitions of words into the work, or working out dictionary definitions appearing in the text in the form of legends of individual drawings. These dictionary definitions, in themselves

287 F. Themerson and S. Themerson, Semantic Divertissements..., p. 16.

288 Guides of this type are still published, for example, The often reprinted nineteenthcentury book by Favell Lee Mortimer Peep of Day. Family Devotional Guide to the Bible. 
quite amusing, when looked at more closely, gain the qualities of a poetic text simply by arrangement on the page, their layout, for example in the sixth fragment of the work, called The Times \& the Spermatozoa indicated and marked in the drawing with the letter " $\mathrm{n}$ ", a house is defined in the following way:

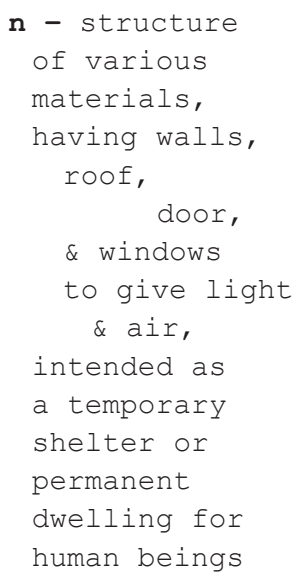

From the point of view of literary genology, Semantic Divertissements would be a hybrid text ${ }^{289}$. The definition "hybrid text" has, I think, special power and semantic carriage and works well with regard to text that attempts to solve the problem of mutual interpenetration and the interference of various forms of expression. The word "hybrid" itself penetrated into Polish from Greek through the Latin word hibrida ('mixture') and indicates multiple meanings - as an expression appearing in the biological sciences, it means an individual born from the intersection of two genetically different individuals; in turn, as a linguistic term, it indicates a word consisting of elements from two different languages, it is, finally, another dictionary word - a composition consisting of different, seemingly unmatching elements. All this is apt and close, but in relation to Semantic Divertissements still distant. The problem is that in the case of polymorphic text it is difficult to remain limited to literary genology. This happens because we cannot only be limited to literariness. Polymorphic text, at least the type we meet in Semantic Divertissements, should be described not in the categories of literariness as well as visuality, and we cannot avoid also other categories such as musicality, even if only because of the fact that the seventh part of the work is titled Trio and contains, as we learn from the footnote, based on Shorter Oxford English Dictionary

289 G. Grochowski, Tekstowe hybrydy. Literackość i jej pogranicza, Wrocław 2000. 
definition of a trio and a drawing presenting his own trio (for voice, violin and piano, which is not actually shown in the drawing, but instead exists in descriptive form, expressed by the Themersonian rules of semantic poetry) and an audience listening to it.

Text and Somatext, on the basis of various codes, reveal to the reader a weave of seemingly loosely connected fragments. In this work, they attempt to incorporate politics, history, economics, religion and culture into their structure, from which result many associations, complex metaphors, various presuppositions; they attempt to embrace the fullness of the reality surrounding man, the fullness of the world, which by nature is broken, divided, incoherent. Working out and defining such a reality, the text must be divided, broken into pieces, fragmentary and as equally heterogeneous as the reality with which it tries to connect and which it tries to master. This text is woven from heterogeneous fragments, but on the basis of enumerations and parataxis - calculated images, thoughts, motifs are arranged in coordination, but also individually. In essence, these fragments form a coherent whole and constitute an attempt to define man, his place in the world, his dependence upon language, politics, history, religions, relationships and social roles that are assigned to him, frequently without his own will. Most of these phenomena, viewed from a distance, are amusing and force us to a description full of irony or even sarcasm, as they inevitably merge with everyday myths, with human convictions that too often rely on current opinions. This distance, expressed with the help of the compilation of signs and portions of fragments, sets the creators in the positions of iconoclasts. Reading the Themersons necessarily requires taking an ironic, iconoclastic view, which results in a mindset of continual movement of ideas; permanent transformation of the ways of seeing the world, people and objects; and of their lack of agreement to ossified forms and outdated conventions of artistic expression. This distance is marked clearly in the second title "divertissements", which is associated with the transitive verb to divert, signifying "to turn around, change the direction of something", "direct, lead to something", "tear off one's attention" and finally "to distract, be enjoyment for someone, to entertain."

So, let us abandon the genological shake-up which in the case of the Themersons usually leads us astray and in no way allows us to establish their uniform determinants. The basic strength and value of the works created by them is that every time they force us not only to think, but to work creatively. The viewerreader is forced into non-stop creativity during reading.

Semantic Divertissements is a non-homogeneous creation that came into being at the meeting point of various semantic codes and incorporates presuppositions 
into an extensive network of intertextual relations. As a polymorphic text, it indicates a special place for the reader, who cannot remain passive to this text, as he is forced to remain vigilant, creative, and, more precisely, to read and/or write this text. How should we read (or also write) this text? Its writing would depend upon combining details, achieved through adding and juxtaposing drawings, texts and fragments. In Semantic Divertissements they are arranged in a closed narrative sequence (determined by a specific density of language, the precision of verbal and visual metaphors), but which - paradoxically - remains open, unfinished and uninterrupted.

Semantic Divertissements is also a work, like many other works by the Themersons, which opens up to experience the broad sense of modernity in a particular way, which includes many important questions about contemporary human condition as a reader of a variety of cultural texts. If we think about this extraordinary work in this way, it becomes an important element in many of the questions posed today by the humanities and addresses issues of multi-coded contemporary culture. The Themersons' works in this field were pioneering and predated many prominent artists and theoreticians. Their work provides answers to questions, which only today are starting to be formulated. 



\section{Bibliography}

Adam J.M. in collaboration with J.-P. Goldenstein, Linguistique et discours littéraire. Théorie et pratique des textes, Larousse, Paris 1976.

Allison N., The Illustrated Encyclopedia of Body-Mind Disciplines, The Rosen Publishing Group, New York 1999.

Anderson N., Critical Somatics: Theory and Method, Marylhurst Univeristy, Portland 2010.

Antologia polskiego futuryzmu i Nowej Sztuki, introduction and commentary compiled Z. Jarosiński, selection and preparation of texts H. Zaworska, Ossolineum, Wrocław 1978, BN I, No. 230.

Anzieu D., Le corps de l'oeuvre, Éditions Gallimard, Paris 1981.

Anzieu D., Le penser. Du Moi-peau au Moi-pensant, Dunod, Paris 1994.

Anzieu D., Le Moi Peau, Dunod, Paris 1995.

Apollinaire G., Calligrammes, transl. A. Hyde Greet, introduction S.I. Lockerbie, University of California Press, Berkeley 1980.

Apollinaire G., Wybór pism, selection, introduction and notes A.Ważyk, PIW, Warsaw 1980.

Aron T., Une seconde revolution saussurienne?, „Langue Française” 1970, No. 7, pp. 56-62.

Aristotle, Physics, transl. R. Waterfield, Oxford University Press, Oxford 2008. Arystoteles, Fizyka, transl. K. Leśniak, PWN, Warsaw 1984.

Attridge D., Poetic Rhythm. An Introduction, Cambridge University Press, Cambridge 1995.

Attridge D., The Singularity of Literature, Routledge, London 2004.

Aviram A.F., Telling Rhythm. Body and Meaning in Poetry, University of Michigan Press, Ann Arbor 1994.

Baetens J., Postérité littéraire des Anagrammes, „Poétique” 1986, No. 66, pp. 217-233. Bakke M., Bio-transfiguracje. Sztuka i estetyka posthumanizmu, Wydawnictwo Naukowe UAM, Poznań 2010.

Balbus S., „Pierwszy ruch jest śpiewanie” (O wierszu Miłosza - rozpoznanie wstępne), [in:] Poznawanie Miłosza. Studia i szkice o twórczości poety, ed.

J. Kwiatkowski, Wydawnictwo Literackie, Cracow 1985, pp. 461-521.

Balcerzan E., Oprócz głosu. Szkice krytycznoliterackie, PIW, Warsaw 1971. 
Baldick Ch., The Concise Oxford Dictionary of Literary Terms, Oxford University Press, Oxford-New York 1991.

Baranowska M., Transfiguracje przestrzeni w twórczości Wata, [in:] Przestrzeń i literatura, ed. M. Głowiński, A. Okopień-Sławińska, Ossolineum, Wrocław 1978, pp. 281-296.

Baranowska M., Surrealna wyobraźnia i poezja, Czytelnik, Warsaw 1984.

Baranowska M., Aleksander Wat: choroba wieku, [in:] Sporne postaci polskiej literatury współczesnej, ed. A. Brodzka, Wydawnictwo IBL PAN, Warsaw 1994, pp. 63-82.

Baranowska M., Księga sonetów, Eventus, Cracow 1997.

Barthes R., Ecoute, [in:] idem, Oeuvres complètes, vol. 5, Éditions du Seuil, Paris 2002.

Barthes R., La peinture est-elle un langage?, [in:] idem, Oeuvres complètes, vol. 3, Éditions du Seuil, Paris 2002.

Batko P., Sonet: gatunek czy strofa. Próba klasyfikacji na tle literatury renesansu $i$ baroku, „Barok” 2007, No. 2, pp. 65-74.

Baudrillard J., L'Échange symbolique et la mort, Gallimard, Paris 1976.

Bedetti G., Henri Meschonnic: Rhythm as Pure Historicity, "New Literary History" 1992, No. 23, pp. 431-450.

Bender R.M., The Sonnet: A Comprehensive Anthology of British and American Sonnets from the Renaissance to the Present, ed. and introduction R.M. Bender, Ch.L. Squier, Washington Square Press, New York 1965.

Benjamin W., The Work of Art in the Age of Mechanical Reproduction, [in:] W. Benjamin, Illuminations, transl. H. Zohn, Schocken Books, New York 1968.

Benjamin W., O kilku motywach u Baudelaire’a, transl. B. Surowska, „Przegląd Humanistyczny" 1970, No. 5-6, pp. 105-117.

Benveniste É., Problèmes de linguistique générale, Gallimard, Paris 1966.

Bloch A., Filigranki na fortepian, illustrations J. Gielniak, Polskie Eydawnictwo Muzyczne, Cracow 1979.

Bodzioch-Bryła B., Ku ciału postludzkiemu... Poezja polska po 1989 roku. Wobec nowych mediów i nowej rzeczywistości, Universitas, Cracow 2006.

The Body, Culture and Society. An Introduction, ed. P. Hancock et al., Open University Press, Buckingham-Philadelphia 2000.

Bohn W., Modern Visual Poetry, Associated University Presses, Cranbury 2001. Bolecki W., Od „postmodernizmu” do „modernizmu” Wat (inne doświadczenie), „Teksty Drugie” 2001, No. 2, pp. 29-39. 
Bonnet Ch., La Communication imprimée, „Communication et langages” 1990, No. 86, pp. 37-52.

Borkowska G., Cudzoziemki. Studia o polskiej prozie kobiecej, Wydawnictwo IBL PAN, Warsaw 1996.

Bourassa L.M., Rythme et sens. Des processus rythmiques en poésie contemporaine, Les Éditions Balzac, Montréal 1993.

Brogan T.V.F., Rhythm, [in:] The New Princeton Encyclopedia of Poetry and Poetics, ed. A. Preminger, T.V.F. Brogan, Princeton University Press, Princeton 1993, pp. 1066-1070.

Bromwich D., American Sonnets. An Anthology, Library of America, New York 2007.

Capello S., Le réseau phonique et le sens. L'interaction phono-sémantique en poésie, Éditions CLUEB, Bologna 1990, pp. 111-115.

Caws M.A., The Art of Interference, Princeton University Press, Princeton 1990.

Chiasson M., Rogers J., Beauty Bare: The Sonnet Form, Geometry and Aesthetics, "Journal of Literature and Science" 2009, vol. 2, No. 1, pp. 48-64.

Ciało, granice, kanon, ed. J. Olejniczak, Wydawnictwo Uniwersytetu Śląskiego, Katowice 2008.

Ciało i tekst. Feminizm w literaturoznawstwie. Antologia szkiców, ed. A. Nasiłowska, vol. 1, Wydawnictwo IBL PAN, Warsaw 2001.

Ciało i tekst. Feminizm w literaturoznawstwie. Antologia szkiców, ed. A. Nasiłowska, vol. 2, Wydawnictwo IBL PAN, Warsaw 2009.

Ciało, płeć, literatura, ed. M. Hornung, M. Jędrzejczak, T. Korsak, Pańtwowe Wydawnictwo Wiedza Powszechna, Warsaw 2001.

Cielesność w polskiej poezji najnowszej, ed. T. Cieślak, K. Pietrych, Wydawnictwo Uniwersytetu Łódzkiego, Łódź 2010.

Close Listening, ed. Ch. Bernstein, Oxford University Press, Oxford 1998.

Codzienne, przedmiotowe, cielesne. Języki nowej wrażliwości w literaturze polskiej XX wieku, ed. H. Gosk, Świat Literacki, Izabelin 2002.

Connor S., The Book of Skin, Reaktion Books, London 2004.

Corrigan P., The Sociology of Consumption. An Introduction, SAGE Publications, London 1997.

Cucinella C., Poetics of the Body. Edna St. Vincent Millay, Elizabeth Bishop, Marilyn Chin, Marilyn Hacker, Palgrave Macmillan, New York 2010.

Cuddon J.A., The Penguin Dictionary of Literary Terms and Literary Theory, Penguine, London 1991.

Culler J., Saussure, William Collins, Glasgow 1976. 
Deguy M., La folie de Saussure, „Critique” 1969, No. 260, pp. 20-26.

Delaperrière M., Polskie awangardy a poezja europejska, transl. A. Dziadek, Wydawnictwo Uniwersytetu Śląskiego, Katowice 2004.

Deleuze G., Critique et clinique, Les Éditions de Minuit, Paris 1993.

Dembińska-Pawelec J., „Poezja jest sztuką rytmu”. O świadomości rytmu w poezji polskiej dwudziestego wieku (Miłosz - Rymkiewicz - Barańczak). Wydawnictwo Uniwersytetu Śląskiego. Katowice 2010.

Derrida J. [Jacques], Introduction: Desistence, [in:] Typography. Mimesis, Philosophy, Politics, ed. P. Lacoue-Labrathe, Harvard University Press, CambridgeMassachusetts 1989.

Derrida J. [Jacques], Le toucher. Jean-Luc Nancy, Éditions Galilée, Paris 2000.

Derrida J. [Jacques], Szibbolet dla Paula Celana, transl. A. Dziadek, FA-art, Bytom 2000.

Derrida J. [Jean], La naissance du corps (Plotin, Proclus, Damascius), Éditions Galilée, Paris 2010.

Dessons G., Introduction à la poétique. Approche des théories de la littérature, Armand Colin, Paris 1995.

Doświadczane, opisywane, symboliczne. Ciało $w$ dyskursach kulturowych, ed. K. Łeńska-Bąk, M. Sztandara, Wydawnictwo Uniwersytetu Opolskiego, Opole 2008.

Drewnowski T., Walka o oddech. O pisarstwie Tadeusza Różewicza, Wydawnictwa Artystyczne i Filmowe, Warsaw 1990.

Dubied A., Les dits et les scènes du fait divers. Travaux de sciences sociales, Droz, Gèneve-Paris 2004.

Dudziński W., Aleksander Wat opisuje swoje schorzenie neurologiczne, „Wiadomości Lekarskie” 1989, No. 10, pp. 665, 684, 692, 702-703.

Dybel P., Ziemscy, słowni i cieleśni. Eseje i szkice, Młodzieżowa Agencja Wydawnicza, Warsaw 1988.

Dziadek A., Rytm i podmiot w liryce Jarosława Iwaszkiewicza i Aleksandra Wata, Wydawnictwo Uniwersytetu Sląskiego, Katowice 1999.

Dziadek A., Anagramy Ferdynanda de Saussure'a - historia pewnej rewolucji, „Teksty Drugie” 2001, No. 6, pp. 109-125 (reprint in: idem, Na marginesach lektury. Szkice teoretyczne, Katowice 2006, pp. 30-58).

Dziadek A., „Soma” $i$, sema” - zarys krytyki somatycznej, [in:] Literackie reprezentacje doświadczenia, ed. W. Bolecki, E. Nawrocka, Wydawnictwo IBL PAN, Warsaw 2007, pp. 69-82.

Eagleton T., Figures of Dissent: Critical Essays on Fish, Spivak, Žižek, and Others, Verso, London 2003. 
Edwards M.W., Sound, Sense and Rhythm. Listening to Greek and Latin Poetry, Princeton University Press, Princeton 2002.

Elsner J., Rozprawa o metryczności i rytmiczności języka polskiego, szczególniej o wierszach polskich we względzie muzycznym, Drukarnia Stanisława Dąbrowskiego, Warsaw 1818.

Either/Or. A Fragment of Life, transl. A. Hannay, Penguin Classics, London 1992.

Eugeniusz Tkaczyszyn-Dycki i krytycy, ed. G. Jankowicz, Korporacja Ha!art, Cracow 2001.

Evans D., Rhythm, Illusion and the Poetic Idea - Baudelaire, Rimbaud, Mallarmé, Brill/Rodopi, Amsterdam-New York 2004.

Farnell B., Dynamic Embodiment for Social Theory: "I Move Therefore I Am", Routledge, London 2012.

Faurisson R., A-t-on lu Rimbaud?, J. J. Pauvert, Paris 1971.

Fechner J.-U., Das deutsche Sonett, Wilhelm Fink Verlag, Munich 1969.

Filipowicz A., Sztuka mięsa. Somatyczne oblicza poezji, Słowo/obraz/terytoria, Gdańsk 2013.

Finch A., The Body of Poetry: Essays on Women, Form, and the Poetic Self, University of Michigan Press, Ann Arbor 2005.

Forajter W., Inwersje, „Pamiętnik Literacki” 2001, No. 1, pp. 179-201.

Frank M., Lultime raison du sujet, Actes Sud, Arles 1988.

Fuller D., The Life in the Sonnets, Continuum, London 2011.

Fuller J., The Sonnet, Methuen, London 1986.

Gazda G., Architektonika graficzna poetyckiego utworu drukowanego, [in:] Literatura i metodologia. Konferencje teoretycznoliterackie $w$ Spale i $w$ Ustroniu, ed. J. Trzynadlowski, Ossolineum, Wrocław 1970, pp. 215-227.

Gendre A., Evolution du sonet français, PUF, Paris 1996.

Gliserman M.J., Psychoanalysis, Language, and the Body of the Text, University Press of Florida, Gainesville 1996.

Głowiński M., Kostkiewiczowa T., Sławiński J., Okopień-Sławińska A., Słownik terminów literackich, Ossolineum, Wrocław 1998.

Going W.T., Scanty Plot of the Ground. Studies in the Victorian Sonnet, The Hague, Paris 1976.

Grajewski W., Jak czytać utwory fabularne?, KAW, Warsaw 1980.

Greber E., Textile Text - Poetolgische Metaphorik und Literaturtheorie. Studien zur Tradition des Wortflechtens und der Kombinatorik, Böhlau Verlag, Köln 2002 . 
Greco M., Illness as a Work of Thought. A Foucauldian Perspective on Psychosomatics, Routledge, London-New York 1998.

Grochowski G., Tekstowe hybrydy. Literackość i jej pogranicza, FUNNA, Wrocław 2000.

Hamer E., English Sonnet: An Anthology, Norwood Editions, Norwood 1975.

Hansen-Löwe A., Intermedialität und Intertextualität: Probleme der Korrelation von Wort- und Bildkunst: Am Beispiel der russischen Moderne, [in:] Dialog der Texte: Hamburger Kolloquium zur Intertextualität, „Wiener Slawistischer Almanach", ed. W. Schmid, W.-D. Stempel, vol. 11, Vienna 1983, pp. 291-360.

Hasty C.F., Meter as Rhythm, Oxford University Press, Oxford 1997.

Hayles N.K., How We Became Posthuman. Virtual Bodies in Cybernetics, Literature and Informatics, University of Chicago Press, Chicago 1999.

Hejmej A., Komparatystyka. Studia literackie - studia kulturowe, Universitas, Cracow 2013.

Hepokoski J., Darcy W., Elements of Sonata Theory, Oxford University Press, Oxford 2006.

Hermansdorfer M., Józef Gielniak, Klub Międzynarodowej Prasy i Książki, Wrocław 1975.

Histoire du corps. Les mutations du regard. Le XX siècle, ed. J.-J. Courtine, vol. 3, Éditions du Seuil, Paris 2006.

Ingarden R., Formy poznawania dzieła literackiego, „Pamiętnik Literacki” 1936, No. 1, pp. 163-192.

Ingarden R., Z teorii dzieła literackiego. Dwuwymiarowa budowa dzieła sztuki literackiej, [in:] Problemy teorii literatury, ed. H. Markiewicz, Ossolineum, Wrocław 1987, pp. 7-54.

Jakobson R., La première lettre de Ferdinand de Saussure à Antoine Meillet sur les anagrammes, [in:] idem, Questions de poétique, Éditions du Seuil, Paris 1973, pp. 190-201.

Jakobson R., Une microscopie du dernier „Spleen” dans „Les Fleurs du mal”, [in:] idem, Question de poétique, Éditions du Seuil, Paris 1973, pp. 420-435.

Jakobson R., Six leçon sur le son et le sens, Éditions du Seuil, Paris 1976.

Jakobson R., Magia dźwięków mowy, [in:] idem, W poszukiwaniu istoty języka, vol. 1, PIW, Warsaw 1989.

Jakobson R., W poszukiwaniu istoty języka, PIW, Warsaw 1989.

Jakobson R., Wough L.R., Sound Shape of Language, Mouton De Gruyter, BerlinNew York 2002.

Jeleński K.A., Zbiegi okoliczności, Instytut Literacki, Paris 1982. 
Jenike L., O znaczeniu rytmu $w$ poezji, a mianowicie o rytmiczności języka polskiego, „Biblioteka Warszawska”, t. 2, Warsaw 1865.

Językowy obraz świata, ed. J. Bartmiński, Wydawnictwo UMCS, Lublin 1990.

Johnston B., Introduction, [in:] Peregrinary, ed. E. Tkaczyszyn-Dycki, transl. B. Johnston, Zephyr Press, Brookline 2008.

Józef Gielniak, edition A. Jakimowicz, Wydawnictwo Artystyczno-Graficzne, Warsaw 1963.

Karłowicz J., Kryński A., Niedźwiedzki W., Słownik języka polskiego, vol. 5, Drukarnia „Gazety Handlowej”, Warsaw 1909.

Kemp F., Das europäische Sonett, Wallstein Verlag, Göttingen 2006.

Kierkegaard S., Albo, albo, transl. J. Iwaszkiewicz, PWN, Warsaw 1982.

Kirchner H., Deutsche Sonette, Reclam-Verlag, Stuttgart 1979.

Kłosińska K., Ciało, pożądanie, ubranie. O wczesnych powieściach Gabrieli Zapolskiej, Wydawnictwo „eFKa”, Cracow 1999.

Kłosiński K., Signifiance, „Pamiętnik Literacki” 1999, No. 2, pp. 11-26.

Kłosiński M., Poszukiwanie znamion intymności w „Mopsożelaznym piecyku” Aleksandra Wata, [in:] Intymność wyrażona (2), ed. M. Tramer, A. Nęcka, Wydawnictwo Uniwersytetu Śląskiego, Katowice 2007, pp. 216-226.

Kraskowska E., Twórczość Stefana Themersona. Dwujęzyczność a literatura, Ossolineum, Wrocław 1989.

Kraskowska E., Piórem niewieścim. Z problemów prozy kobiecej dwudziestolecia międzywojennego, Wydawnictwo Naykowe UAM, Poznań 1999.

Kristeva J., Séméiotikè. Recherches pour une sémanalyse, Éditions du Seuil, Paris 1969.

Kristeva J., La Révolution du langage poétique, Éditions du Seuil, Paris 1974.

Kristeva J., Le sujet en procès, [in:] eadem, Polylogue, Éditions du Seuil, Paris 1977.

Kristeva J., Powers of Horror. An Essay on Abjection, transl. L.S. Roudiez, Columbia University Press, New York 1982.

Kryszak J., Ból mój, mój demon, „Poezja” 1974, No. 7-8, pp. 135-138.

Kuryś T., Rytm. Z dziejów terminu i pojęcia, [in:] Wiersz. Podstawowe kategorie opisu, part 1: Rytmika, ed. J. Woronczak, Poetyka. Zarys encyklopedyczny, ed. M.R. Mayenowa, vol. 2, Ossolineum, Wrocław 1963.

Laing R., Podzielone ja, transl. M. Karpiński, Dom Wydawniczy Rebis, Poznań 1999.

Łapiński Z., „Psychosomatyczne sq moje wiersze” (Impuls motoryczny w poezji Juliana Przybosia), „Teksty Drugie” 2002, No. 6, pp. 9-17. 
Łebkowska A., Jak ucieleśnić ciało?, „Teksty Drugie” 2011, No. 4, pp. 11-27.

Le corps du texte. Pour une anthropologie des textes de la tradition juive, ed. F. Heymann, D. Storper Perez, CNRS Éditions, Paris 1997.

Lemma A., Under the Skin. Psychoanalytic Study of Body Modification, Routledge, New York 2010.

Liddell H.G., Scott R., A Greek-English Lexicon, Clarendon Press, Oxford 1996.

Lipski J.J., Szkice o poezji. Instytut Literacki, Paris 1987.

Łoś J.N., Wiersze polskie w ich dziejowym rozwoju, Nakładem Gebethnera i Wolffa,Warsaw 1920.

Łukasiewicz J., Laur i ciało, PIW, Warsaw 1971.

The Making of a Sonnet: A Norton Anthology, ed. E. Hirsch, E. Boland, W. W. Norton \& Company, New York 2008.

Małecki A., Gramatyka języka polskiego szkolna, author’s edition, Lwów 1906.

Masson D.I., Sound-Repetition Terms, [in:] Poetics. Poetyka, ed. K. Wyka, vol. 1, PWN, Warsaw 1961, pp. 189-199.

Mastalski A.S., Prototypowość struktury wierszowej jako element kształtowania się semantyki tekstu, [in:] Potencjat wiersza, ed. W. Sadowski, Wydawnictwo IBL PAN, Warsaw 2013, pp. 28-42.

Meschonnic H., L'enjeu du langage dans la typographie, „Littérature” 1979, No. 35, pp. 46-56.

Meschonnic H., Critique du rythme. Anthropologie historique du langage, Verdier, Lagrasse 1982.

Meschonnic H., Les états de la poétique, PUF, Paris 1985.

Meschonnic H., La Rime et la vie, Verdier, Lagrasse 1989.

Meschonnic H., Politique du rythme. Politique du sujet, Verdier, Lagrasse 1995.

Meschonnic H., Modernité, modernité, Gallimard, Paris 2000.

Michałowski P., Ponowoczesna sonetomania?, [in:] Polska proza i poezja po 1989 roku wobec tradycji, ed. A. Główczewski, Wydawnictwo Uniwersytetu Mikołaja Kopernika, Toruń 2007.

Michałowski P., Głosy, formy, światy. Warianty poezji nowoczesnej, Universitas, Cracow 2008.

Między słowem a ciałem, ed. L. Wiśniewska, Wydawnictwo Akademii Bydgoskiej, Bydgoszcz 2001.

Miłosz Cz., Przedmowa, [in:] A. Wat, Mój wiek, Polonia, London 1981.

Miłosz Cz., Prywatne obowiązki, Instytut Literacki, Paris 1985. 
Mleczko S., Serce a heksametr czyli gieneza metryki poetyckiej w zwiazku z estetycznym kształceniem się języków, szczególnie polskiego, Księgarnia E. Wende i S-ka, Warsaw 1901.

Moncond'huy D., Le sonnet. Anthologie, Gallimard, Paris 2005.

Morier A., Dictionnaire de poétique et de rhétorique, PUF, Paris 1975.

Mumenthaler M., Neurologia, PZWL, Warsaw 1979.

Nancy J.-L., Corpus, Éditions Métailié, Paris 2000.

Nancy J.-L., À lécoute, Éditions Galilée, Paris 2002.

Nancy J.-L., Corpus, transl. M. Kwietniewska, Słowo/obraz/terytoria, Gdańsk 2002.

Nancy J.-L., Au fond des images, Éditions Galilée, Paris 2004.

Nancy J.-L., Corpus, transl. R.A. Rand, Fordham University Press, New York 2008.

Nancy J.-L., Le plaisir au dessin, Éditions Galilée, Paris 2009.

The New Encyclopaedia Britannica, vol. 10, London 1991.

Nycz R., Język modernizmu, Wydawnictwo „Leopoldinum” Fundacji dla U niwersytetu Wrocławskiego, Wrocław 1997.

Olejniczak J., W-Tajemniczanie - Aleksander Wat, Wydawnictwo Uniwersytetu Śląskiego, Katowice 1999.

Opacki I., Mówione rytmem. „Zadymka” Juliana Tuwima, [in:] idem, Mówione wierszem, Wydawnictwo Gnome, Katowice 2004, pp. 192-213.

Oppenheimer P., The Birth of the Modern Mind: Self, Consciousness, and the Invention of the Sonnet, Oxford University Press, Oxford 1989.

Pamięć głosów. O twórczości Aleksandra Wata, ed. W. Ligęza, Universitas, Cracow 1992.

Panas W., Tajemnica siódmego anioła, „Roczniki Humanistyczne” 1999, vol. XLVII, No. 1, pp. 9-26.

Pascal B., Myśli, transl. T. Żeleński (Boy), introduction S. Skwarczyńska, PAX, Warsaw 1953.

Pelc J., Obraz - słowo - znak. Studium o emblematach w literaturze staropolskiej, Ossolineum, Wrocław 1973.

Pawelec D., Wirpsza wielokrotnie, Instytut Mikołowski, Mikołów 2013.

Piekarski I., Narcyzm, anagram, sygnatura. Uwagi o pewnej obsesji (i literaturze), [in:] Psychoanalityczne interpretacje literatury: Freud, Jung, Fromm, Lacan, ed. E. Fiała, I. Piekarski, Wydawnictwo KUL, Lublin 2012, pp. 313-334.

Pitts V., In the Flesh: The Cultural Politics of Body Modification, Springer, New York 2003. 
Plato, Timajos, Kritias albo Atlantyk, translation, introduction, commentary and index P. Siwek, PWN, Warsaw 1986.

„Poezja” 1973, No. 6 - special issue dedicated to the sonnet.

Polska genologia. Gatunek w literaturze wspótczesnej, ed. R. Cudak, PWN, Warsaw 2009.

Profilowanie w języku i w tekście, ed. J. Bartmiński, Wydawnictwo UMCS, Lublin 1998.

Protevi J., Political Affect. Connecting the Social and the Somatic, University of Minnesota Press, Minneapolis 2009.

Prusiński A., Podstawy neurologii klinicznej, PZWL, Warsaw 1989.

Pruszyński A., O grach intersemiotycznych Stefana Themersona, [in:] Archiwum Themersonów w Polsce, ed. A. Dziadek, D. Rott, Wydawnictwo Uniwersytetu Śląskiego, Katowice 2003, pp. 33-74.

Pruszyński A., Dobre maniery Stefana Themersona, Słowo/obraz/terytoria, Gdańsk 2005.

Przyboś J., Zapiski bez daty, PIW, Warsaw 1970.

Przymuszała B., Szukanie dotyku. Problematyka ciała $w$ polskiej poezji współczesnej, Univeristas, Cracow 2006.

Pszczołowska L., Sonet od renesansu do Młodej Polski, [in:] Słowiańska metryka porównawcza. Sonet, ed. L. Pszczołowska, vol. 5, Wydawnictwo IBL PAN, Warsaw 1993.

Pszczołowska L., Wiersz polski. Zarys historyczny, Leopoldinum, Wrocław 1997.

Rajewsky I.O., Intermedialität, Francke, Tübingen-Basel 2002.

Rancière J., La chair des mots. Politiques de l’écriture, Éditions Galilée, Paris 1998.

Rey J.-M., Saussure avec Freud, „Critique” 1973, No. 309, pp. 136-167.

Riffaterre M., La production du texte, Éditions du Seuil, Paris 1979.

Ritz G., Nić w labiryncie pożadania. Gender i płeć w literaturze polskiej od romantyzmu do postmodernizmu, transl. B. Drąg, A. Kopacki, M. Łukasiewicz, «Wiedza Powszechna», Warsaw 2002.

Roark T., Aristotle on Time. A Study of the Physics, Cambridge University Press, Cambridge 2011.

Robinson D., Estrangement and the Somatics of Literature. Tolstoy - Shklovsky Brecht, The Johns Hopkins University Press, Baltimore 2008.

Robinson D., Displacement and the Somatics of Postcolonial Culture, Ohio State University Press, Columbus 2013.

Roof J., The Poetics of DNA, University of Minnesota Press, Minneapolis 2007. 
Rypson P., Obraz słowa. Historia poezji wizualnej, Akademia Ruchu, Warsaw 1989.

Rypson P., Piramidy, słońca, labirynty. Poezja wizualna w Polsce od XVI do XVIII wieku, Wydawnictwo : Neriton, Warsaw 2002.

Sacks-Galey P., Calligramme ou écriture figurée, Lettres modernes, Paris 1988.

Sadowski W., Wiersz wolny jako tekst graficzny, Universitas, Cracow 2004.

Saussure F. de, Anagrammes Homériques, ed. P.-Y. Testenoire, Lambert-Lucas, Limoges 2013.

Sauter P., Rythme et corporéité chez Claude Simon, „Poétique” 1994, No. 77, pp. 19-39.

Sauvanet P., Le rythme grec, d'Héraclite à Aristote, PUF, Paris 1999.

Sauvanet P., Le rythme et la raison. Rythmanalyses, vol. 1-2, Éditions Kimé, Paris 2000.

Schwitters K., Hausmann R., PIN and the story of PIN, introduction J. Reichardt, design A. Lovell, Gaberbocchus Press, London 1962.

Seymour W., Remaking the Body: Rehabilitation and Change, Routledge, London 1998.

Shusterman R., Performing Live, Cornell University Press, Ithaca 2000.

Shusterman R., O sztuce i życiu. Od poetyki hip-hopu do filozofii somatycznej, transl. W. Małecki, research collaboration A. Chmielewski, Alta 2, Wrocław 2007.

Shusterman R., Świadomość ciała. Dociekania z zakresu somaoestetyki, transl. W. Małecki, S. Stankiewicz, academic editor K. Wilkoszewska, Universitas, Cracow 2008.

Shusterman R., Somatic Style, "The Journal of Aesthetics and Art Criticism" Spring 2011, No. 2(69), pp. 147-159.

Siedlecki F., Pisma, PIW, Warsaw 1989.

Stownik grecko-polski, based on the dictionary by Z. Węclewski edited by O. Jurewicz, vol. 1, PWN, Warsaw 2000.

Słownik literatury staropolskiej. Średniowiecze - Renesans - Barok, ed. T. Michałowska, Ossolineum, Wrocław 2002.

Słownik rodzajów i gatunków literackich, ed. G. Gazda, S. Tynecka-Makowska, Universitas, Cracow 2006.

Słowo i obraz. Materiały sympozjum Komitetu Nauk o Sztuce Polskiej Akademii Nauk, ed. A. Morawińska, PWN, Warsaw 1982.

Śliwiński P., Przygody z wolnością. Uwagi o poezji współczesnej, Znak, Cracow 2002. 
Śmietana U., Od écriture femininine do somatekstu, „Przegląd FilozoficznoLiteracki” 2003, No. 1(3), pp. 153-171.

Smolka I., Dziewięć światów. Współczesne poetki polskie, Wydawnictwo IBL PAN, Warsaw 1997.

Śniecikowska B., „Nuż w uchu”? Koncepcje dźwięku w poezji polskiego futuryzmu, Wydawnictwo Uniwersytetu Wrocławskiego, Wrocław 2008.

Sonet polski, selection, introduction and explanations W. Folkierski, Ossolineum, Wrocław 1925, BN I, No. 82.

Sosnowski A., Skarb kibica/Sonet. http://poewiki.org/index.php?title=Skarb_ kibica/Sonet (accessed: 14.05.2014).

The Sound of Poetry/The Poetry of Sound, ed. M. Perloff, C. Dworkin, University of Chicago Press, Chicago 2009.

The Sound Studies Reader, ed. J. Sterne, Routledge, New York-London 2012.

Spiller M., The Development of the Sonnet. An Introduction, Routledge, LondonNew York 1992.

Spire A., Plaisir poétique et plaisir musculaire, Corti, Paris 1949.

Starobinski J., Les Anagrammes de Ferdinand de Saussure, „Mercure de France” 1964, No. 1204, pp. 243-262.

Starobinski J., Les mots sous les mots: texts inédits des Cahiers d'anagrammes de Ferdinand de Saussure, [in:] To Honor Roman Jakobson, Mouton, Paris 1967, pp. 1906-1917.

Starobinski J., Le nom caché, [in:] L’analyse du langage théologique, le nom de Dieu, ed. E. Castelli, Aubier, Paris 1969.

Starobinski J., Le texte dans le texte, extraits inédits des Cahiers d'anagrammes de Ferdinand de Saussure, „Tel Quel” 1969, No. 37, pp. 3-33.

Starobinski J., Les mots sous les mots. Les anagrammes de Ferdinand de Saussure, Gallimard, Paris 1971.

Stulecie Przybosia, ed. S. Balbus, E. Balcerzan, Wydawnictwo Naukowe UAM, Poznań 2002.

Świerkosz M., Feminizm korporalny w badaniach literackich. Próba wyjścia poza metaforykę cielesności, „Teksty Drugie” 2008, No. 1/2, pp. 75-95.

Synnott A., The Body Social. Symbolism, Self and Society, Routledge, London 1993.

Szkice o poezji Aleksandra Wata, ed. J. Brzozowski, K. Pietrych, Wydawnictwo IBL PAN, Warsaw 1999.

Testenoire P.-Y., Ferdinand de Saussure à la recherche des anagrammes, LambertLucas, Limoges 2013. 
Themerson S., Jankel Adler. An Artist Seen from One of Many Possible Angles. With Twelve Full Page Drawings by Jankel Adler, Gaberbocchus Press, London 1948.

Themerson S., Kurt Schwitters in England, Gaberbocchus Press, London 1958.

Themerson F., Themerson S., Semantic Divertissements, Gaberbocchus Press, London 1962.

Themerson S., Kurt Schwitters on a time chart, „Typographica” 1967, No. 16.

Themerson S., Apollinaire's Lyrical Ideograms, Gaberbocchus Press, London 1968.

Themerson F., Themerson S., St. Francis and the Wolf of Gubbio or Brother Francis' Lamb Chops. An Opera in 2 Acts, Gaberbocchus Press, AmsterdamLondon 1972.

Themerson S., O potrzebie tworzenia widzeń, [in:] Europejskie manifesty kina. Antologia, introduction, selection and compilation A. Gwóźdź, Wiedza Powszechna, Warsaw 2002.

Themerson S., Wiersze wybrane, foreword, selection and compilation J. Reichardt, Wydawnictwo Uniwersytetu Śląskiego, Katowice 2003.

Tkaczyszyn-Dycki E., Oddam wiersze w dobre ręce (1988-2010), Biuro Literackie, Wrocław 2010.

Turner B.S., Regulating Bodies. Essays in Medical Sociology, Routledge, London 1992.

Turner B.S., The Body and Society. Explorations in Social Theory, SAGE, London 1996.

Turner B.S., The Sociology of the Body, [in:] idem, The New Blackwell Companion to Social Theory, Wiley-Blackwell, Oxford 2009.

Tuwim J., Pegaz dęba, Iskry, Warsaw 2008.

Urbańska D., Sonet od Młodej Polski do współczesności, [in:] Słowiańska metryka porównawcza. Sonet, ed. L. Pszczołowska, vol. 5, Wydawnictwo IBL PAN, Warsaw 1993.

Urbańska D., Wiersz wolny. Próba charakterystyki systemowej, Wydawnictwo IBL PAN, Warsaw 1995.

Venclova, T., Aleksander Wat. Life and Art of an Iconoclast, Yale University Press, New Haven-London 1996.

Venclova T., Aleksander Wat - obrazoburca, transl. J. Goślicki, Wydawnictwo Literackie, Cracow 1997.

Vernon J., Poetry and Body, University of Illinois Press, Chicago 1979. 
Waldby C., The Visible Human Project. Informatic Bodies and Posthuman Medicine, Routledge, London 2000.

Walker A., Hans von Bülow. A Life and Times, Oxford University Press, Oxford 2009.

W „antykwariacie anielskich ekstrawagancji”. O twórczości Aleksandra Wata, ed. J. Borowski, W. Panas, Wydawnictwo KUL, Lublin 2002.

Wat A., Notatniki, ed. A. Dziadek, J. Zieliński, Wydawnictwo IBL PAN, Warszawa 2015.

Weinstone A., Avatar Bodies. A Tantra for Posthumanism, University of Minnesota Press, Minneapolis 2004.

Wierzbicka A., Język, umyst, kultura, PWN, Warsaw 1999.

Wiśniewski J., Ku harmonii? Poetyckie style stuchania muzyki $w$ wierszach polskich autorów po 1945 roku, Wydawnictwo Uniwersytetu Łódzkiego, Łódź 2013.

Witkiewicz S.I., Nowe formy w malarstwie. Szkice Estetyczne. Teatr, ed. J. Leszczyński, PWN, Warsaw 1974.

Wolf W., Intermediality Revisited. Reflections on Word and Music Relation in the Context of a General Typology of Intermediality, [in:] Word and Music Studies. Essays in Honour of Steven Paul Scher and on Cultural Identity and the Musical Stage, ed. S.M. Lodato, S. Aspden, W. Bernhart, GA Rodopi, AmsterdamNew York 2002, pp. 13-34.

Wóycicki K., Forma dźwiękowa prozy polskiej i wiersza polskiego, PWN, Warsaw 1960.

Wyka K., Super flumina babylonis, [in:] idem, Rzecz wyobraźni, PIW, Warsaw 1959, pp. 413-440.

Zarębianka Z., Tropy sacrum w literaturze XX wieku. Od zagadnień motywicznych do perspektyw hermeneutycznych, Homini, Bydgoszcz 2001.

Zawodziński K.W., Studia z wersyfikacji polskiej, Osolineum, Wrocław 1954.

Zaworska H., Nurt „Nowej Sztuki”, [in:] Literatura polska 1918-1975, ed. A. Brodzka, H. Zaworska, S. Żółkiewski, vol. 1, Wiedza Powszechna, Warsaw 1975.

Zgorzelski Cz., Liryka w pelni romantyczna, PIW, Warsaw 1981.

Zieliński J., Spowiedź syna królewskiego, „Twórczość” 1984, No. 3, pp. 77-87.

Życzyński H., Problemy wersyfikacji polskiej, part I: Rytm poetycki, Dom Książki Polskiej, Lublin 1934. 


\section{Texts forming the basis for analysis or reference}

Alciatus A., Emblematum libellus, ed. R. Krzywy, Wydział Polonistyki UW, Warsaw 2002.

Ausone, Poèmes divers, transl. É. Ducoté, Librairie de l'art indépendant, Paris 1897.

Barańczak S., Antologia angielskiej poezji metafizycznej XVII stulecia, PIW, Warsaw 1991.

Biedrzycki M., Hołd (dwa sonety) - Macie swoich poetów. Liryka polska urodzona po 1960 r. - wypisy, selection and compilation P. Dunin-Wąsowicz, J. Klejnocki, K. Varga, 2nd edition, corrected and expanded, Lampa i Iskra Boża, Warsaw 1997, p. 20.

Cendrars B., Poésies complètes, vol. 1, Denoël, Paris 2001.

Corbière T., Les amours jaunes, edition E. Aragon, C. Bonnin, PUM, Toulouse 1992.

Czaplic M., Podarek na Slawne Wesele Zacnie Urodzonych Oblubiencow, Szlachetnego Pana, P. Stephana Zabinskiego, y Szlachetney Panny, P. Anny Chrosciewskiey. Przez Macieia Czaplica Klec. ofiarowany, Poznań 1622.

Dachnowski K., Philantropia, Lubo Wiekom dtugo pamiętny dwoch nowych Małzonkow Związek Ie ${ }^{\circ}$ Mści P. Łvkasza $z$ Charmęz Charmęskiego: Y Jey Mości Panny Maryny Zolewskiey z Zolewa, Przy Weselu w Krakowie dnia 3. Febr. Roku 1631, Cracow 1631.

Foks D., Sonet drogi, Biuro Literackie, Legnica 2000.

Fredro A.M., Peristromata Regum, Gdańsk 1660.

Grzebalski M., Stynne i świetne, Biuro Literackie, Wrocław 2004.

Haraucourt E., La Légende des sexes, poèmes hystériques et profanes, Imprimé à Bruxelles pour l'auteur, Bruxelles 1882.

Hulewicz W., Sonety instrumentalne, F. Hoesick, Warsaw 1928.

Jankowski J., Sonety wstępujace (od jedno- do pięciozgłoskowych), F. Hoesick, Warsaw 1934.

Lubomirski S.H., Adverbium moralium, Warsaw 1688.

Mallarmé S., Rzut kośćmi nigdy nie zniesie przypadku, transl. T. Różycki, Korporacja Ha!art, Cracow 2005.

Manuzio A., Ut esset perpetuum Stanislai Nyegossewii [...] in nomen Venetum Pietatis argumentum, tum vero cum Aldo Mannucci dignum mutuae caritatis pignus [...], Venice 1584 . 
Milton J., Raj utracony, transl. M. Słomczyński, Wydawnictwo Literackie, Cracow 1974. Original Paradise Lost, London 1668.

Morsztyn Z., Emblemata, edition P. and J. Pelcowie, Neriton, Warsaw 2001.

Oulipo, La littérature potentielle (Créations, Re-créations, Récréations), Gallimard, Paris 2003.

Pasewicz E., Muzyka na instrumenty strunowe, perkusję i czelestę, WBPICAK, Poznań 2010.

Pasewicz E., Pałacyk Bertolda Brechta, EMG, Cracow 2011.

Pawlikowska-Jasnorzewska M., Szkicownik poetycki, Towarzystwo Wydawnicze w Warszawie, Warsaw 1939.

Pollakówna J., Wiersze zebrane, Instytut Mikołowski, Mikołów 2012.

Queneau R., Sto tysięcy miliardów wierszy, transl. J. Gondowicz, Korporacja Ha!art, Cracow 2008.

Rességuier J. de, Sonnet. Épitaphe, „France littéraire” 1835, vol. 20, p. 174.

Sajnóg Z., Reisepsychose. Sonety totalne - typed manuscript, private collection, texts unpublished.

Tkaczyszyn-Dycki E., Oddam wiersze w dobre ręce (1988-2010), Biuro Literackie, Wrocław 2010.

Tkaczyszyn-Dycki E., Imię i znamię, Biuro Literackie, Wrocław 2011.

Valéry P., Tel Quel, Gallimard, Paris 1943.

Venantius Fortunatus, Venantii Honorii Clementiani Fortunati Carminum, epistolarum et expositionum libri XI Accessere Rhabani Mauri... poemata sacra, Moguncja 1617.

Waśniowski W., Wielkiego Boga wielkiey Matki ogrodek..., Cracow 1644.

Wat A., JA z jednej strony i JA z drugiej strony mego mopsożelaznego piecyka, Nakładem Bronisławy Skra-Kamińskiej, Warsaw 1920.

Wat A., bez tytułu, „Wiadomości” 1968, No. 14(1149), p. 2.

Wat A., Dziennik bez samogłosek, edition K. Rutkowski, Polonia, London 1986.

Wat A., Ucieczka Lotha. Proza, edition K. Rutkowski, Polonia, London 1988.

Wat A., Poezje, edition A. Micińska, J. Zieliński, postword J. Zieliński, Czytelnik, Warsaw 1997.

Wat A., Wybór wierszy, introduction and edition A. Dziadek, Ossolineum, Wrocław 2008, BN I, No. 300.

With the Skin. Poems of Aleksander Wat, transl. Cz. Miłosz, L. Nathan, Ecco Press, New York 1989. 


\section{Index of names}

A

Abbot of Tivoli 126

Adam Jean Michel 201

Adamczewska Izabela 159

Adler Jankel 181, 213

Albert-Birot Pierre 179, 181

Alciatus Andrea 168, 170

Allison Nancy 10, 201

Anderson Nicole 17, 201

Anzieu Didier 49, 53, 123, 201

Apollinaire Guillaume 135, 158,

178-182, 201, 213

Aragon Elisabeth 132, 215

Aristoxenus 27

Aron Thomas 38, 201

Aristotle 27, 117-119, 201, 210

Asbden Suzanne 149

Asbjørnsen Peter Christen 61

Attridge Derek 28, 74, 201

Augé Marc 78, 116

Ausone, see Ausonius 99, 215

Ausonius 99

Aviram Amitai F. 29, 201

B

Baetens Jan 37, 201

Baird Tadeusz 94, 148

Baka Józef 153

Bakke Monika 10, 201

Balbus Stanisław 25, 43, 44, 146, 201, 212

Balcerzan Edward 36, 43, 201, 212

Baldick Chris 28, 202

Ball Hugo 191

Baranowska Małgorzata 49, 55, 128, 202

Barańczak Stanisław 42-44, 52, 127, $165,204,215$
Barbey d'Aurevilly Jules Amédée 62

Barthes Roland 26, 82, 111, 116, 187, 202

Bartmiński Jerzy 30, 207, 210

Bartók Béla 116, 117

Batko Piotr 130, 202

Baudelaire Charles 29, 39, 58, 60, 62, 132, 202, 205

Baudrillard Jean 202

Bedetti Gabriela 29, 202

Bender Robert M. 127, 202

Benjamin Walter 97, 202

Bens Jacques 138

Benveniste Émile 15, 24, 26-28, 39, 202

Berg Alban 94, 95

Bergson Henri 43

Bernhart Walter 149, 214

Bernstein Charles 29, 111

Besantinus 165

Będziński Wawrzyniec Jan 176

Białoszewski Miron 102, 134, 143, 153

Biedrzycki Miłosz 138, 142, 215

Blake William 44

Bloch Augustyn 98, 202

Bodzioch-Bryła Bogusława 10, 202

Bogucki Andrzej 114

Bohn Willard 179, 202

Boland Eavan 128, 208

Bolecki Włodzimierz 47, 55, 159, 202, 204

Bonnet Christian 157, 158, 203

Bonnin Claude 132, 215

Borkowska Grażyna 14, 203

Borowski Jarosław 56, 214

Bourassa Lucie M. 29, 203

Brecht Bertold 17, 109, 210, 216

Breton André 58 
Brodziński Kazimierz 34

Brodzka Alina 69, 202, 214

Brogan Terry V.F. 29, 203

Bromwich David 128, 203

Bruegel Pieter (the Elder) 95, 96

Brzękowski Jan 35

Brzozowski Jerzy 56, 212

Bülow Hans Guido von 21, 214

Burgan Patrick 148

C

Capello Sergio 29, 203

Castelli Enrico 38, 212

Caws Mary Ann 193, 203

Cellius Erhard 176

Cendrars Blaise 136, 215

Cézanne Paul 191

Charmęski Łukasz 174, 215

Chiasson Matthew 124, 203

Chmielewski Adam 18, 211

Chyczyński Stanisław 143

Cieślak Tomasz 14, 74, 92, 203

Claudel Paul 158

Cocteau Jean 179

Connor Steven 53, 75, 203

Corbière Tristan 132, 215

Corrigan Peter 12, 203

Courtine Jean-Jacques 9, 206

Cucinella Catherine 15, 203

Cudak Romuald 128, 210

Cuddon John Anthony 27, 203

Culler Johnathan 37, 203

Czachorowski Stanisław Swen 127

Czaplic Maciej 167, 215

Czyżewski Tytus 41, 179

D

Dachnowski Jan Karol 174, 175, 215

Dachy Marc 189

Dante Alighieri 61, 62, 126

Dantyszk Jan 170

Darcy Warren 119, 206
De Quincey Thomas 58, 60, 62

Decugis Henri 58

Deguy Michel 37, 38, 204

Dehnel Jacek 143

Delaperrière Maria 179, 204

Deleuze Gilles 9, 18, 204

Dembińska-Pawelec Joanna 42, 44, 204

Derrida Jacques 21, 26, 49, 52, 74

Derrida Jean 204

Dessons Gérard 29, 204

Doesburg Teo van 179

Dosiadas of Crete 164, 165

Drąg Bronisław 210

Drewnowski Tadeusz 13, 204

Dubied Annik 157, 204

Ducoté Éduard 99, 215

Dudziński Witold 53, 204

Dufresny Charles 160

Dunin-Wąsowicz Paweł 138, 215

Dworkin Craig 90, 212

Dybel Paweł 13, 204

Dziadek Adam 19, 30, 32, 33, 36, 47, $49,54,58,60,146,169,179,180$, 187, 204, 210, 214, 216

Dziechcińska Hanna 168

E

Eagleton Terry 17, 204

Edison Thomas Alva 193

Edwards Mark W. 90, 205

Ellington Duke 148

Elsner Józef 34, 205

Evans David 29, 205

F

Farnell Brenda 12, 13, 205

Faurisson Robert 123, 205

Fechner Jörg-Ulrich 128, 205

Fiała Edward 36, 209

Fiamma Gabriele 131

Fiedorczuk Julia 143 
Filipowicz Anna 14, 15, 205

Finch Annie 123, 205

Foks Darek 140, 215

Folkierski Władysław 125, 126, 129, 144, 212

Forajter Wacław 85, 205

Foucault Michel 9, 13

Frank Manfred 19, 205

Fredro Andrzej Maksymilian 170, 215

Freud Zygmunt 36, 39, 48, 209, 210

Fuller David 146, 205

Fuller John 126, 129, 146, 205

G

Gautier Théophile 58

Gaye R. K. 118

Gazda Grzegorz 68, 130, 159, 179, 205, 211

Gendre André 144, 205

Gielniak Józef 97, 98, 202, 206, 207

Gliserman Martin J. 123, 205

Głowicka Katarzyna 56

Głowiński Michał 28, 55, 73, 130, 159, 202, 205

Główczewski Aleksander 128, 208

Going William T. 129, 205

Goldenstein Jean-Pierre 201

Gondowicz Jan 138, 216

Gosk Hanna 14, 203

Goślicki Jan 213

Górecka Ewa 92

Grabowiecki Sebastian 131

Grajewski Wincenty 36, 205

Greber Erika 144, 205

Greco Monica 55, 206

Grochowiak Stanisław 97, 127

Grochowski Grzegorz 197, 206

Grzebalski Mariusz 141, 144, 145, 215

Guattari Félix 9

Gutenberg Johannes 193

Gutorow Jacek 143

Gwóźdź Andrzej 213
$\mathbf{H}$

Hamer Enid 127, 206

Hannay Alastair 63, 205

Hancock Philip 12, 202

Hansen-Löwe Aage 149, 206

Haraucourt Edmond 133, 148, 215

Hardie R. P. 118

Hasty Christopher F. 28, 206

Hausmann Raoul 184, 211

Hayles N. Katherine 10, 206

Heffernan James A.W. 98

Heidegger Martin 118

Hejmej Andrzej 149, 192, 206

Hepokoski James 119, 206

Herbert George 165, 181, 185

Herbert Zbigniew 115

Hermansdorfer Mariusz

Heymann Florence 98, 206

Hirsch Edward 128, 208

Hölszky Adriana 148

Horace 37, 103

Hornung Magdalena 14, 203

Hraban Maur 176

Huelsenbeck Richard 191

Hulewicz Witold 147, 161, 215

Hyde Greet Anne 179, 201

I

Ingarden Roman 25, 26, 206

Iwaszkiewicz Jarosław 19, 63, 117, 204, 207

J

Jakimowicz Andrzej 98, 207

Jakobson Roman 26, 37-40, 42, 64, 145, 206, 212

Jankowicz Grzegorz 77, 117-119, 205

Jankowski Jerzy 70

Jankowski Józef 134, 215

Jarosiński Zbigniew 61, 201

Jasieński Bruno 41, 179

Jastrun Mieczysław 76 
Jeleński Konstanty Aleksander 51, 52, $56,70,206$

Jenike Ludwik 34, 207

Jędrzejczak Marcin Johnston Bill 14, 203

Joyce James 68

Jurewicz Oktawiusz 78, 211

Jurzysta Marcin 74

K

Kaczorowski Stanisław P. 132

Karczmarski Jacek 148

Karłowicz Jan Aleksander 35, 82, 207

Karpiński Maciej 59, 207

Kemp Friedhelm 128, 207

Khlebnikov Velimir 39, 41, 68, 70, 145

Kiełkowski Maurycy 176

Kierkegaard Søren 63, 207

Kirchner Hartmut 128, 207

Klejnocki Jarosław 138, 215

Kłosińska Krystyna 14, 207

Kłosiński Krzysztof 19, 207

Kłosiński Michał 56, 207

Kochanowski Jan 126, 170, 172

Koffler Józef 94

Kołaczkowska Anna 130

Konnak Paweł (Koñjo) 150

Kopacki Andrzej 210

Koprowski Piotr Paweł 148

Korczyński Adam 159

Korsak Tadeusz 14, 203

Kostkiewiczowa Teresa 28, 73, 74, 130, 159, 205

Kraskowska Ewa 14, 188, 207

Kristeva Julia 15, 19, 24, 29, 31-34, 38, 40, 42, 57, 60, 95, 154, 207

Kryński Adam Antoni 35, 207

Kryszak Janusz 52, 207

Krzywy Roman 168, 215

Kuryś Tadeusz 23, 207

Kwiatkowski Jerzy 25, 146, 201

Kwietniewska Małgorzata 209
L

Lacoue-Labrathe Philippe 21, 204

Laing Roland 59, 207

Laszczkowski Jacek 148

Le Lionnais François 137

Lekszycki Paweł 143

Lemma Alessandra 10, 208

Lentino Giacomo da 126

Lescure Jean 161, 162

Leszczyński Jan 55, 214

Leśmian Bolesław 43, 102

Leśniak Kazimierz 117, 118, 201

Levi Anthony 195

Levi Honor 195

Lévi-Strauss Claude 124

Liddell Henry George 78, 208

Ligęza Wojciech 52, 209

Linde Samuel Bogumił 82

Lipiński Karol 148

Lipski Jan Józef 52, 208

Lockerbie S.I. 179, 201

Lodato Suzanne M. 149, 214

Lotman Yuri 26

Lovell Anna 184, 211

Lubomirski Stanisław Herakliusz 170, 171,215

Lucretius 37

Lullo Ramòn 60

Lumière August Marie Louis and

Louis Jean 123

Łapiński Zdzisław 43, 207

Łebkowska Anna 14, 208

Łeńska-Bąk Katarzyna 14, 204

Łoś Jan Nepomucen 35, 208

Łukasiewicz Jacek 13, 208

Łukasiewicz Małgorzata 210

M

Maj Witold 127

Majerski Tadeusz 94

Mallarmé Stephané 29, 158, 179, 205, 215 
Małecki Antoni 34, 35, 208

Małecki Wojciech 18, 211

Manuzio Aldo 176, 177, 215

Marinetti Filippo 179

Markiewicz Henryk 26, 206

Masson David I. 31, 208

Mastalski Arkadiusz Sylwester 130, 208

Mauss Marcel 17

Mayenowa Maria Renata 23, 207

Meek Mary Elizabeth 26

Meillet Antoine 37, 39, 50, 206

Mepham John 42

Merleau-Ponty Maurice 13

Meschonnic Henri 15, 18, 19, 21-24, $26,29-32,36,42,77,78,86,95$, $120,158,202,208$

Mesens Edouard Léon Théodore 189

Michałowska Teresa 159, 211

Michałowski Piotr 128, 143, 144, 208

Micińska Anna 61, 63, 216

Mickiewicz Adam 56, 85, 115, 127

Międzyrzecki Artur 135

Mikołajewski Jarosław 81

Milton John 182, 183, 216

Miłosz Czesław 25, 42-44, 51, 52, 55, $57,65,85,135,146,201,204,208$, 216

Miłosz Oskar (Oscar de Lubicz Milosz) 44

Mleczko Stanisław 21, 22, 44, 209

Młodożeniec Stanisław 41

Moe Jørgen 61

Moncond'huy Dominique 128, 209

Moniuszko Stanisław 148

Morawińska Agnieszka 168, 211

Morier Henri 27, 28, 87, 126, 129, 209

Morsztyn Hieronim 130

Morsztyn Jan Andrzej 126

Morsztyn Zbigniew 169, 170, 216

Mortimer Favell Lee 196

Moss Piotr 148
Mostacci Jacopo 126

Mumenthaler Marco 209

Mykietyn Paweł 148

$\mathbf{N}$

Nałkowska Zofia 85

Nancy Jean-Luc 52, 57, 111, 166, 168, 193, 204, 209

Nasiłowska Anna 14, 203

Nathan Leonard 52, 216, 221

Nawrocka Ewa 47, 204

Nęcka Agnieszka 56, 207

Niedźwiedzki Władysław 35, 207

Niegoszewski Stanisław 176

Niemec Maciej 143

Nietzsche Friedrich 43, 96

Nieznanowski Stefan 159

Noailles Anna de 145

Nycz Ryszard 58, 209

O

Okopień-Sławińska Aleksandra 28, 55, 73, 130, 159, 202, 205

Olejniczak Józef 14, 56, 203, 209

Olszański Grzegorz 134

Opacki Ireneusz 25, 125, 209

Oppenheimer Paul 126, 209

Orska Joanna 113

Ovid 37

$\mathbf{P}$

Panard Charles-François 181

Panas Władysław 36, 56, 61, 209, 214

Pascal Blaise 195, 209

Pasewicz Edward 45, 109-122, 216

Pawelec Dariusz 127, 209

Pawlikowska-Jasnorzewska Maria 145, 216

Pelc Janusz 168, 169, 209, 216

Pelc Paulina 169, 216

Perec Géorges 185

Perloff Marjorie 29, 90, 212 
Peszek Maria 11

Petrarch Francesco 126

Picasso Pablo 191

Piekarski Ireneusz 36, 209

Piero delle Vigne 126

Pietrych Krystyna 14, 56, 74, 92, 203, 212

Piszek Maciej 148

Pitts Victoria L. 10, 209

Plato 26, 27, 32, 33, 78, 165, 210

Plutarch 78

Płuciennik Jarosław 56, 68, 69

Podgórnik Marta 143

Pollak Roman 159

Pollakówna Joanna 45, 89, 92-95, 98-100, 102, 105, 107, 216

Pomorski Adam 69

Pontanus Jacobus 169

Porcius Publius (properly Johannes

Leo Placentius) 161

Preminger Alex 29, 203

Protevi John 10, 210

Prusiński Antoni 210

Pruszyński Artur 187, 210

Przerwa-Tetmajer Kazimierz 145

Przyboś Julian 35, 43, 94, 144, 210

Przybylski Jacek 127

Przymuszała Beata 14, 15, 210

Pszczołowska Lucylla 24, 125, 129, 210, 213

Publilius Optatianus Porfirius 176

Q

Queneau Raymond 138, 185, 216

Queval Jean 137

$\mathbf{R}$

Racki Jan 176

Radko Piotr 148

Rajewsky Irina O. 149, 210

Rancière Jacques 123, 210

Rand Richard A. 52, 209
Read Herbert 185

Redon Odilon 99

Reichardt Jasia 184, 195, 211

Rej Mikołaj 170, 172

Rességuier Jules de 133, 216

Reverdy Pierre 158

Rey Jean-Michel 39, 210

Rhodes Simmias of 164

Riffaterre Michel 210

Rilke Rainer Maria 76

Rimbaud Arthur 29, 60, 123, 205

Rinaldo d'Aquino 126

Ritz German 14, 210

Roark Tony 118, 210

Robinson Douglas 17, 210

Rogers Janine 124, 203

Roof Judith 15, 210

Rossetti Dante Gabriel 61

Rossowski Jan 167

Rott Dariusz 187, 210

Roudiez Leon Samuel 57, 207

Roussel Raymond 158

Różycki Tomasz 143, 179, 215

Rudnicki Sławomir 127

Rutkowski Krzysztof 55, 60, 216

Rymkiewicz Jarosław Marek 42, 44, 127, 204

Rypson Piotr 164, 174, 176, 179, 211

Rzewuska Anna Ludwika 173

S

Sacks-Galey Pénélope 179, 211

Sadowski Witold 24, 125, 130, 208, 211

Sajnóg Zbigniew 150, 152, 216

Sand George 62

Saussure Ferdinand de 31, 32, 36-40, $42,50,69,71,78,90,145,203,204$, 206, 210-212

Sauvanet Pierre 28, 211

Sawicki Karol 173

Schönberg Arnold 94, 95 
Schlegel Wilhelm August 125, 129

Schmid Wolf 149, 206

Schwitters Kurt 179-191, 211, 213

Scott Robert 78, 208

Sendecki Marcin 150

Seneca 37

Seymour Wendy 10, 211

Sęp-Szarzyński Mikołaj 126, 172

Shakespeare William 148

Shklovsky Viktor 17, 210

Shusterman Richard 12, 13, 17, 18, 73, $74,86,211$

Siddal Elizabeth 62

Siedlecki Franciszek 23, 211

Simmias of Rhodes 164, 165

Siwek Paweł 210

Skoczko Milena 61

Skwarczyńska Stefania 209

Sławiński Janusz 28, 73, 129, 130, 159, 205

Słonimski Antoni 127

Smolka Iwona 93, 212

Socrates 78

Sojka Stanisław 148

Sosnowski Andrzej 84, 128, 129, 144, 212

Sośnicki Dariusz 143

Spiller Michael R.G. 124, 126, 212

Spire André 111, 212

Squier Charles L. 127, 202

Stankiewicz Sebastian 18, 211

Starobinski Jean 37-39, 212

Stempel Wolf-Dieter 149, 206

Stern Anatol 41, 43

Sterne Jonathan 90, 138, 212

Sting (properly Gordon Matthew

Sumner) 148

Storper Perez Danielle 123, 208

Surowska Barbara 202

Suska Dariusz 125

Suter Patrick 29

Synnott Anthony 53, 212
Sztandara Magdalena 14, 204

Śliwiński Piotr 125, 150, 211

Śmieja Florian 133

Śmietana Urszula 157, 212

Śniecikowska Beata 41, 42, 56, 64, 68, 69,212

Świerkosz Monika 157, 212

Świetlicki Marcin 146

$\mathrm{T}$

Tanalska Anna 145

Testenoire Pierre-Yves 36-38, 50, 211, 212

Themerson Franciszka 45, 158, 179, 192, 194, 196, 199, 213

Themerson Stefan 45, 132, 158, 179-196, 198, 199, 207, 210, 213

Theocritus of Syracuse 164

Thomas Dylan 102

Tkaczyszyn-Dycki Eugeniusz 45, 73, $75,77,80,81,84,86,205,207,213$, 216

Tolstoy Leo 17, 210

Tomaszewski Boris 32

Tramer Maciej 56, 207

Trzynadlowski Jan 179, 205

Turner Bryan Stanley 9, 10, 12, 213

Tuwim Julian 25, 68, 161-163, 209, 213

Tylman van Gameren 171

Tynecka-Makowska Słowinia 68, 130, 159, 211

U

Urbańska Dorota 23, 125, 213

V

Valéry Paul 53, 90, 216

Varga Krzysztof 138, 215

Venantius Fortunatus 174, 176, 216

Venclova Tomas 49, 52, 56, 67-69, 213 
Vernon John 70, 213

Villon François 96

W

Waldby Catherine 10, 214

Waller Margaret 33

Walker Alan 21, 214

Waśniowski Wojciech 163, 166, 216

Wat Aleksander 43, 45, 47, 49, 51-53, $55,56,65,67,114,127,202,204$, 209, 213, 216

Wat Ola (Paulina) 55, 56

Wats, Ola (Paulina) and Aleksander 55,56

Ważyk Adam 135, 180, 201

Webern Anton 94

Weinstone Ann 10, 214

Węclewski Zygmunt 78, 211

Wierzbicka Anna 30, 214

Wilkoszewska Krystyna 18, 211

Williams Drid 13

Wirpsza Witold 127, 209

Wiśniewska Lidia 14, 208

Wiśniewski Jerzy 109, 214

Witkiewicz Stanisław Ignacy 65, 214

Wittlin Józef 146

Wojaczek Rafał 128
Wolf Werner 149, 214

Woronczak Jerzy 23, 207

Wough Linda R. 39, 206

Wóycicki Kazimierz 23, 214

Wyka Kazimierz 31, 52, 208, 214

$\mathbf{Z}$

Zadura Bohdan 128, 129

Zagajewski Adam 125

Zalewski Cezary 76, 77

Zapolska Gabriela 14

Zarębianka Zofia 93, 214

Zawodziński Karol Wiktor 23, 214

Zaworska Helena 61, 63, 69, 201, 214

Zeyl Donald. J. 32

Zgorzelski Czesław 25, 214

Zielińska Lidia 148

Zieliński Jan 52, 54, 58, 61, 63, 89, 90, 94, 103, 214, 216

Zolewska Maryna 174

Żeleński (Boy) Tadeusz 209

Żółkiewski Stefan 69, 214

Żukowski Tadeusz 127

Żuławski Jerzy 134

Żurowski Maciej 180

Życzyński Henryk 35, 214 